\title{
INTERDEPENDENCIES BETWEEN AGRICULTURE AND MACROECONOMICS IN UKRAINE
}

\author{
Doctoral Dissertation \\ submitted for the degree of Doctor of Agricultural Sciences \\ of the Faculty of Agricultural Sciences \\ Georg-August-University of Göttingen (Germany)
}

by

Sergiy Ivanovych Zorya

born in Zhytomyr, Ukraine

May 2003 
D7

$1^{\text {st }}$ examiner: Prof. Dr. Stephan von Cramon-Taubadel $2^{\text {nd }}$ examiner: Prof. Dr. Ulrich Koester

Date of oral examination: May 15, 2003 


\section{Acknowledgement}

I would like to express my special gratitude to Prof. Dr. Stephan von CramonTaubadel for his supervision of my research, the very prompt attention to the work, constructive discussions and advises, and especially for ensuring my participation in various research and policy consulting projects that greatly improved a quality of the dissertation. I thank Prof. Dr. Ulrich Koester for his valuable feedback as a second supervisor of the dissertation. I also express my gratitude to Ludwig Striewe for 'enabling' my study in Göttingen and for a great professional assistance during the course of my study.

My gratitude goes to the entire staff of the "Lehrstuhl Agrarpolitik" for being very helpful and for the excellent working environment. I sincerely thank Christa Körber for her great logistic support. My acknowledgement for assistance in correcting this dissertation and making valuable suggestions is directed to John Schamper from the USAID Mission to Ukraine and Lidiya Novinskaya, my mother-in-law, also from the USAID Mission.

My special thanks also go to Sasha Starikov, Serhiy Demyanenko, Tania Redina and Veronika Movchan from the Institute for Economic Research and Policy Consulting in Ukraine for their professional assistance and valuable suggestions on Ukraine's economy.

I am very grateful to my wife Svitlana and children Viktor and Tania for all mercies great and small during the course of work. Finally, a special gratitude goes to my parents for investing much time in my education and for supporting me in all possible forms. 


\section{CONTENTS}

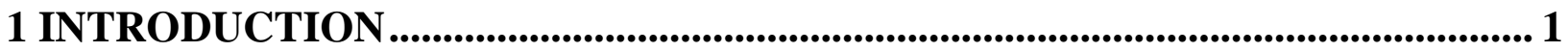

1.1 STATEMENT OF THE PROBLEM AND DEFINITION OF THE GOALS................ 1

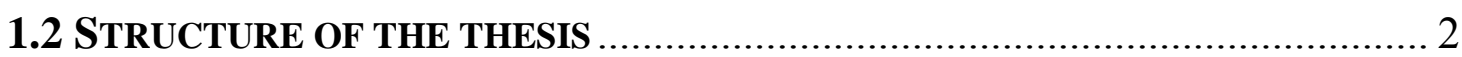

2 THEORETICAL FOUNDATIONS OF INTERLINKAGES BETWEEN AGRICULTURE AND MACROECONOMICS ................................................ 4

2.1 INTRODUCTION TO INTERLINKAGES BETWEEN MACROECONOMICS AND

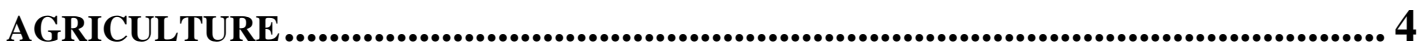

2.2 GENERAL EQUILIBRIUM FRAMEWORK .............................................. 6

2.3 REAL EXCHANGE RATE AND AGRICULTURE ........................................ 7

2.3.1 Literature overview ........................................................................ 7

2.3.2 Dependent Economy Model.......................................................... 13

2.3.3 Krueger-Schiff-Valdes approach ............................................. 20

2.3.4 Exchange rate misalignment ....................................................... 21

2.4 INTEREST RATES AND AGRICULTURE............................................. 24

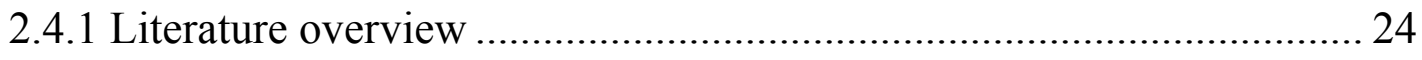

2.4.2 Interest and exchange rates in an open economy framework .............. 27

2.4.3 Interest rates, farm production costs, and farm debts........................ 35

2.4.4 Storage costs and interest rate developments................................. 37

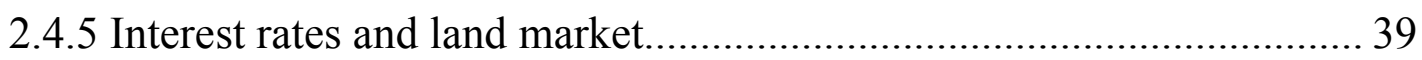

2.5 AGRICULTURE AND MACROECONOMIC EQUILIBRIUM......................... 40

2.5.1 Literature overview ................................................................... 40

2.5.2 Linkages between agriculture and non-agriculture .......................... 44

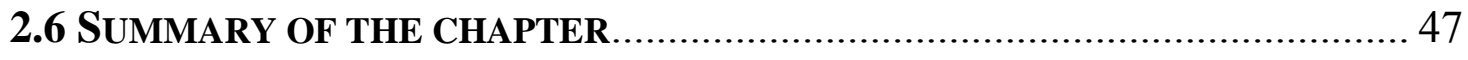

3 UKRAINIAN ECONOMY IN TRANSITION .............................................. 49

3.1 GENERAL ECONOMIC PERFORMANCE IN UKRAINE .............................. 49

3.1.1 Development of gross domestic product in Ukraine ......................... 49

3.1.2 Fiscal policy in Ukraine ....................................................... 51

3.1.3 Monetary and exchange rate policies in Ukraine ............................. 58

3.1.4 Foreign trade policy in Ukraine ..................................................... 71 


\subsection{AGRICULTURAL DEVELOPMENT IN UKRAINE}

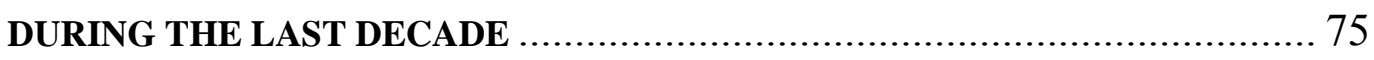

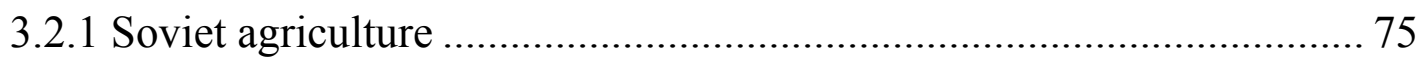

3.2.2 Development of agricultural output in Ukraine .................................... 76

3.2.3 Importance of agriculture for Ukrainian economy................................ 77

3.2.4 Structure of the agricultural sector in Ukraine ...................................... 79

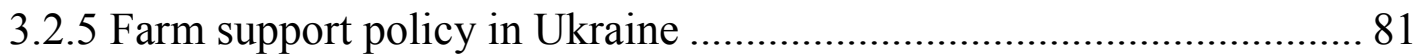

3.2.6 Agricultural trade and pricing policy in Ukraine ................................ 85

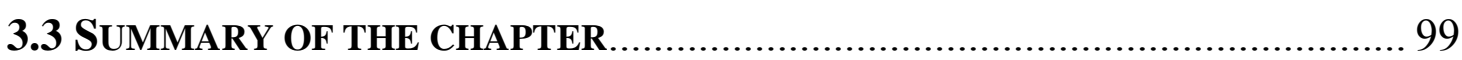

\section{EMPIRICAL ESTIMATIONS OF INTERDEPENDENCIES BETWEEN} AGRICULTURE AND MACROECONOMICS IN UKRAINE ...................... 100

4.1 REAL EXCHANGE RATE AND AGRICULTURE IN UKRAINE ........................ 100

4.1.1 Equilibrium real exchange rate in Ukraine ..................................... 100

4.1.2 Impact of macroeconomic policy on agricultural incentives ............... 115

4.1.3 RER misalignment and agricultural growth in Ukraine...................... 117

4.2 INTEREST RATES AND AGRICULTURE IN UKRAINE................................ 120

4.2.1 Real exchange and interest rates in Ukraine ...................................... 120

4.2.2 Interest rates and farm production costs in Ukraine........................... 122

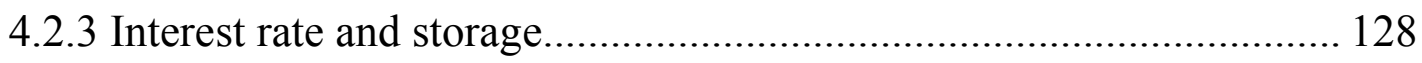

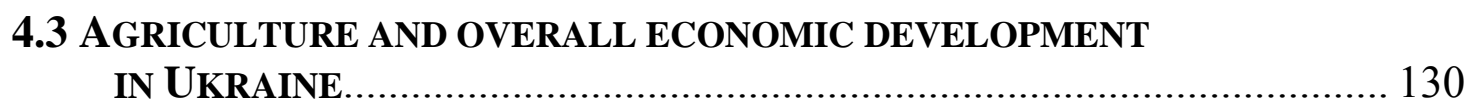

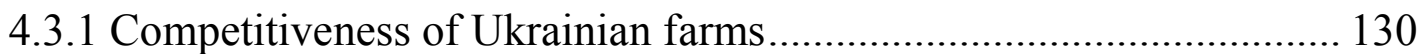

4.3.2 Agriculture and macroeconomic stability in Ukraine ......................... 134

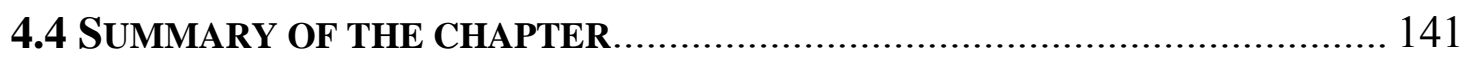

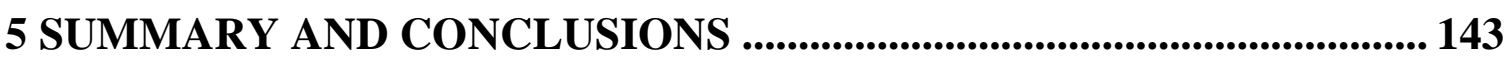

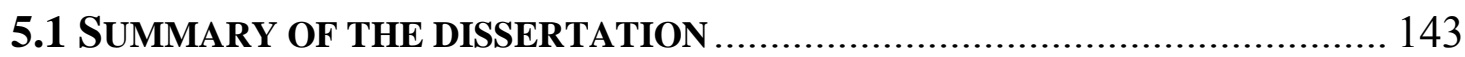

5.2 CONCLUSIONS AND POLICY IMPLICATIONS ............................................ 145

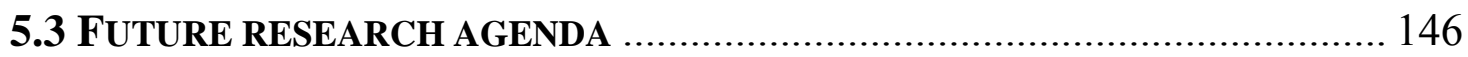

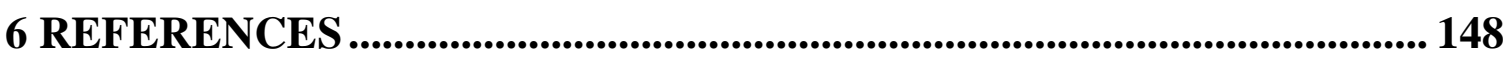

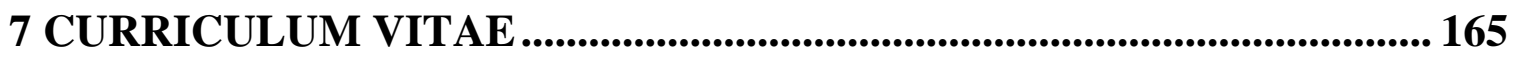




\section{LIST OF FIGURES}

Page

Figure 1: Impact of macroeconomic policy on agri-food policy ................................... 5

Figure 2: Economy-wide effects of farm support policies ............................................. 6

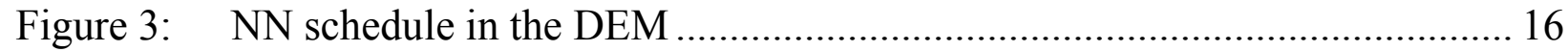

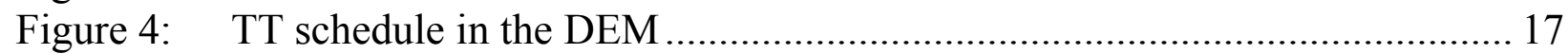

Figure 5: Overall equilibrium in the DEM .......................................................... 18

Figure 6: Adjustment mechanism in the DEM: elimination of excessive inflation ..... 19

Figure 7: Adjustment mechanism in the DEM: elimination of excessive inflation with capital inflows ................................................................................ 19

Figure 8: Goods and money market equilibrium in IS-LM model................................ 28

Figure 9: Internal and external balance in the Mundell-Fleming model ....................... 29

Figure 10: Effects of monetary policy under fixed exchange rate ................................. 31

Figure 11: Effects of monetary policy under fixed exchange rate ................................ 31

Figure 12: Effects of an increase in money stock under flexible exchange rate ............. 32

Figure 13: Effects of fiscal expansion under flexible exchange rate.............................. 32

Figure 14: Effects of loss of export revenue and necessity of real depreciation............. 33

Figure 15: Short- and long-term effects of monetary expansion.................................... 34

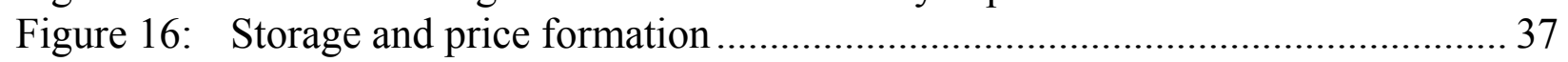

Figure 17: Relationship between prices over time ..................................................... 38

Figure 18: Changes of real GDP in Ukraine, 1991-2002, (in \% to previous year) ........ 50

Figure 19: Changes in real GDP in selected CEE countries, 1989-2001, (in \%) ............ 50

Figure 20: Prices and money supply in Ukraine, 1996-2001 .................................... 59

Figure 21: Liquid international reserves in Ukraine, 1996-2001, $(\$ \mathrm{mln})$...................... 60

Figure 22: Interest rates in Ukraine, 1993-1996, (in \% per quarter) .............................. 61

Figure 23: Interest rates in Ukraine, 1997-2001, (in \% per quarter) .............................. 62

Figure 24: The development of real exchange rates in Ukraine,

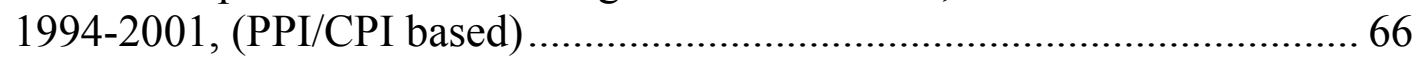

Figure 25: Effective nominal and real exchange rates in Ukraine, 1994-2001 .............. 68

Figure 26: Impact of the effective RER on trade balance in Ukraine, 1996-2001 ......... 70

Figure 27: Ratio of labour productivity to ULC in Ukraine, 1993-2001 ....................... 71

Figure 28: Foreign trade of goods and services in Ukraine, 1994-2001 ....................... 72

Figure 29: The GAO in Ukraine by type of farms, 1990-2001 .................................... 77

Figure 30: Distribution of the farms on the rate of profitability in Ukraine in 2000 .....80

Figure 31: Relationships between state farm support and GAO,

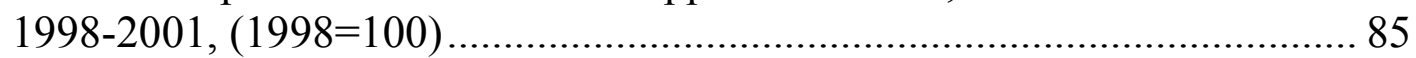

Figure 32: The ratio between prices in the Soviet Union and on world markets ........... 86

Figure 33: The price indexes for selected products in Ukraine, 1991-2000 .................. 86

Figure 34: Actual and equilibrium real exchange rates in Ukraine, 1996-2001 .......... 114

Figure 35: Misalignment of the RER in Ukraine, 1996-2001, in \% to ERER ............. 114

Figure 36: Aggregated direct and indirect NPR on average for wheat, barley, corn, and sunflower seeds in Ukraine, 1996-2001 ......

Figure 37: Development of the effective RER and real interest rates in Ukraine,

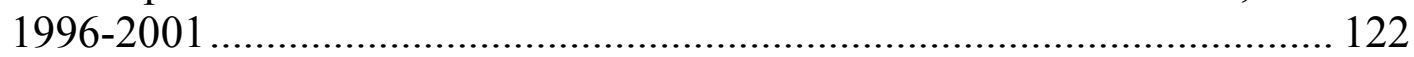

Figure 38: Important factors of determining credit interest rates ............................... 123

Figure 39: Net grain export in Ukraine, 1996/97-2002/03 marketing years, (in $\mathrm{mln}$ tons) 


\section{LIST OF TABLES}

Page

Table 1: Estimates of the incidence parameter $(\omega)$ as it affects agriculture ................. 10

Table 2: Direct and indirect rates of nominal protection, 1960-1984,

period average in $\%$................................................................................ 11

Table 3: Influence of monetary and fiscal policies on some agricultural and

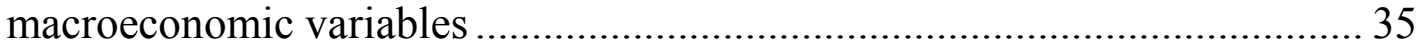

Table 4: Schematic presentation of gross margin calculations ........................................ 36

Table 5: Agricultural growth linkages to the economy's total factor productivity....... 46

Table 6: Key indicators of the fiscal policy in Ukraine, 1992-2001 ............................. 52

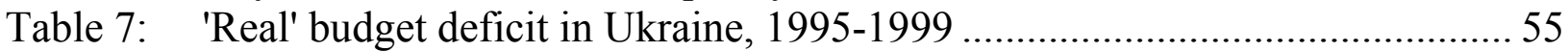

Table 8: Financing of the budget deficit in Ukraine, 1992-2001 ................................ 56

Table 9: Foreign debts, debt service and reserve adequacy in Ukraine, 1994-2001 ....57

Table 10: Actual and implied real interest rates in Ukraine, 1996-2001,

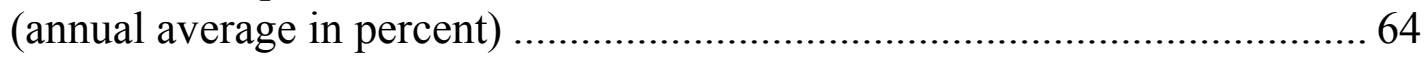

Table 11: Currency corridor policies in Ukraine, 1997-1999 …………………............. 65

Table 12: Structure of merchandise exports and imports in Ukraine, 1994-2000, (in \% to total export and import) ................................................................ 72

Table 13: Openness of Ukraine's economy, 1994-2001 ………………………........... 73

Table 14: Trade weighted import tariffs in Ukraine, 1995-2001 …............................... 73

Table 15: Production of selected agricultural products in Ukraine, 1985-2001, (in mln tons) .......................................................................................... 77

Table 16: Role of agriculture in Ukrainian economy, 1991-2001 …………............... 78

Table 17: State budget support of the farms in Ukraine, 1998-2001, (UAH mln) ......... 82

Table 18: Significance of state farm support in Ukraine, 1998-2001 …......................... 83

Table 19: Import MFN tariff rates for major agri-food products in Ukraine................... 90

Table 20: Tariff escalation in Ukraine ..................................................................... 92

Table 21: Nominal rates of protection for selected agricultural products in Ukraine,

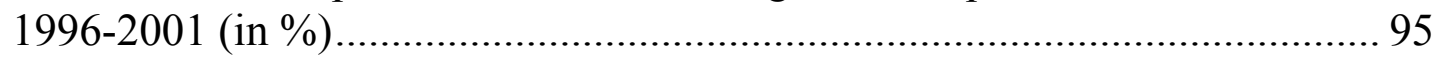

Table 22: Effective rates of protection for selected agricultural products in Ukraine,

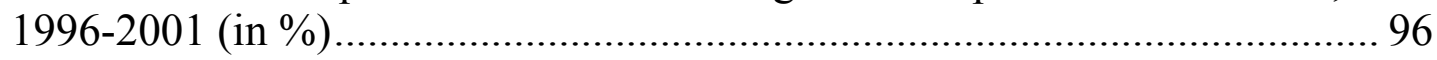

Table 23: Distortion in domestic producer price ratios for selected agricultural products in Ukraine (in terms of wheat prices) compared to those on the world market, 1997-2000

Table 24: Macroeconomic indicators of Ukraine from RER regression, 1996-2001 (year on average)

Table 25: Augmented Dickey-Fuller test for presence of unit root, 1996Q1-2001Q4. 109

Table 26: Cointegrating regression, 1996Q1-2001Q4 …............................................... 109

Table 27: Contribution of economic fundamentals to changes of the RER in Ukraine, 1996Q1-2001Q4

Table 28: Error correction regression, 1996Q1-2001Q4 …........................................ 111

Table 29: Nominal and effective rates of protection of several crop products in Ukraine, in \%, 1996-2001

Table 30: Augmented Dickey-Fuller test for presence of unit root, 1996Q1-2001Q4 118

Table 31: Error-correction regression of agricultural growth in Ukraine..................... 119 
Table 32: Calculation of the real interest rates in Ukraine, (in \%, end of year), 1994-2001

Table 33: 'Typical' production technologies and costs of major crops in Ukraine in 2001

Table 34: Structure of production costs of selected agricultural products in Ukraine in 2001 (in \% to total costs).....

Table 35: The financing structure of the large farms in Ukraine, 1992-2000

Table 36: PCR and DRC for crop production in Ukrainian farms on average, 1996-2001

Table 37: Farm support and national budget in Ukraine, 1998-2001 .......................... 135

Table 38: Structure of consumer price index in Ukraine, 1997-2001, (in $\%$ to previous year, at end of year) 


\section{List of Abbreviations}

\begin{tabular}{ll} 
ADF & Augmented Dickey-Fuller Test \\
AMS & Agro-Monetary System \\
BEER & Behaviour Equilibrium Exchange Rate \\
bln & Billion \\
BP & Balance of Payments \\
CAE & Collective Agricultural Enterprise \\
CAP & Common Agricultural Policy of the EU \\
CAPFY & Net capital inflows to GDP \\
CEE & Central and Eastern Europe \\
CGE & Computable General Equilibrium Model \\
CIF & Cost, Insurance, Fright \\
CIS & Commonwealth of Independent States \\
DAF & Supplied to the border \\
DBR & Deutsche Bank Research \\
DEM & Dependent Economy Model \\
DRC & Domestic Resource Cost \\
EBRD & European Bank for Reconstruction and Development \\
ECM & Error-Correction Model \\
EPR & Effective Protection Rate \\
ERER & Equilibrium Real Exchange Rate \\
ERS & Economic Research Service of the USDA \\
EU & European Union \\
EXCMON & Excess of money supply \\
FAO & UN Food and Agricultural Organisation \\
FAT & Fixed Agricultural Tax \\
FEER & Fundamental Equilibrium Exchange Rate \\
FDI & Foreign Direct Investments \\
FISC & Rate of fiscal deficit to monetary base \\
FOB & Free on Board \\
GAO & \\
& Gross Agricultural Output \\
\hline
\end{tabular}




\begin{tabular}{ll} 
GDP & Gross Domestic Product \\
GOV & Government expenditures to GDP \\
GOU & Government of Ukraine \\
IER & Institute for Economic Research and Policy Consulting \\
IFPRI & International Food and Policy Research Institute \\
IMF & International Monetary Fund \\
mln & Million \\
NER & Nominal Exchange Rate \\
NBU & National Bank of Ukraine \\
NOMDEV & Nominal devaluation of exchange rate \\
NPR & Nominal Protection Rate \\
OECD & Organisation for Economic Cooperation and Development \\
OPEN & Rate of openness \\
PCR & Private Cost Ratio \\
RER & Real Exchange Rate \\
PPP & Purchasing Power Parity \\
PSE & Producer Subsidy Estimate \\
RERMIS & Real exchange rate misalignment \\
R\&D & Research and Development \\
SSCU & State Statistics Committee of Ukraine \\
TECHNO & Technological progress \\
ton & Tonne \\
UAH & Ukrainian Hryvnia \\
ULC & Unit Labour Costs \\
USDA & U.S. Department of Agriculture \\
VAR & Vector Autoregressive Model \\
VAT & Value-Added Tax \\
WTO & World Trade Organisation \\
\$ & U.S. Dollar \\
$€$ & Euro \\
\hline
\end{tabular}




\section{Introduction}

\subsection{Statement of the problem and definition of the goals}

The Berlin Wall fell more than a decade ago. Communism fell in the Soviet republics two years later, and newly established independent states started their enormous political and economical changes. In 1991, Ukraine was among the most promising countries in Eastern Europe for a quick transition from a centrally-planned to a market economy. But actual development after more than a decade of transition has dashed these expectations. Agricultural economists in particular might be disappointed by actual outcomes, because being the agrarian republic of the Soviet Union, Ukraine's agricultural sector especially was expected to contribute to the overall economic development (see, for example, KOESTER, 1998; LIEFERT and SWINNEN, 2002).

Ukraine's economic transition has presented many challenges. "In the course of its brief transition history, the country experienced hyperinflation, a decade-long output contraction, currency crises, and substantial social hardship" (ODLING-SMEE, 2003: 5). The economy gradually stabilised by the end of 1999, and started to recover at unexpectedly high growth rates. Agricultural development in Ukraine has strongly coincided with the general economic changes. It can be clearly divided into two distinctive phases: during the first period (1991-1999) the agricultural output contracted severely, while during the second period (since 2000) agriculture was among the sectors which strongly contributed to the recent economic recovery. The cumulative decline of gross agricultural output (GAO) during the first period equalled to $67 \%$, while during 2000-2002 the agricultural production grew by almost $20 \%$ in real terms (UEPLAC, 2002).

A commonly used approach to explain the main driving forces of the agricultural development in Ukraine is to consider agricultural (i.e. sector-specific) policies and issues. Although the macroeconomic policy is not completely excluded from the policy discussions in respect of agriculture, its role and transmission mechanisms are often either ignored or weakly understood. Is the macroeconomic policy of the Government of Ukraine (GOU) really worth being ignored to consider an agricultural development?

World-wide experience clearly answers "no", demonstrating a significant importance of the macroeconomics for the farming sector in both developed and developing countries. There is an enormous body of literature, developed from the pioneer paper of EDWARD SCHUH entitled "The exchange rate and U.S. agriculture" in 1974 and the World Bank study for developing countries under the direction of ANNE O. KRUEGER, MAURICE SCHIFF and AlBERTO VALDES in late 1980s, which supports the conclusion that both unsound macroeconomic policy and urban biased industrialisation strategy do a great damage to the agricultural development, while robust economic growth stimulates the success of farm performance (SCHUH, 1974; KRUEGER et al., 1988). In the transition economies of Central and Eastern Europe (CEE), general economic reforms have also strongly affected agricultural transformation and performance, "in particular with regard to creating stability, better access to capital and technology, and privatisation" (SWINNEN, 2001: 13). AlEX MCCALLA, Director of the Department for Agriculture and Natural Resources at the World Bank, stated: 
"Underpinning our analysis must be a fundamental understanding of open-economy macroeconomics. In a liberalised economy, macro prices - interest rates, exchange rates and inflation rates - will likely have more to do with success in the sector than will specific interventions. We need to understand the linkages" (cited in KUHL, 1998: 1).

However, an understanding of the linkages between macroeconomics and agriculture will be not complete without consideration of interdependencies. Agriculture occupies an important place in Ukrainian economy, generating roughly $14 \%$ of overall GDP and employing $24 \%$ of the working population (SSCU, 2002). In this respect Ukrainian agriculture could be certainly compared with the farming sector in many developing countries of Latin America and East Asia. Just as agriculture suffers from macroeconomic policy failures, similarly sustainable economic development is impossible without efficient agricultural sector, thus "finding the policy environment that creates mutual growth is needed" (TIMMER, 1998a: 115).

In spite of the substantial literature on the interdependence of the macroeconomics and agriculture that appeared during last decades, there is no applied research for Ukraine and probably only a few for CEE transition economies. To fill this gap, this study tests the hypothesis that what is true elsewhere is also true in transition country such as Ukraine. In open economies, the exchange rates, inflation, budget deficit, or interest rates are likely to strongly affect the agricultural sector performance, while general economic development is probably to be highly dependent upon positive contributions of agriculture. The major tasks of the dissertation are the following:

- $\quad$ Fill the gap by understanding the agricultural transition in Ukraine by linking it to the country's macroeconomic development;

- Demonstrate the channels through which the agricultural sector in Ukraine influences the macroeconomy, and estimate the magnitude of its influence; and

- $\quad$ Create the basis for future research of this unexplored issue in Ukraine.

\subsection{Structure of the thesis}

The second chapter presents the theoretical analysis of interdependencies between macroeconomics and agriculture. The presentation of the relevant theories of the impact of important macroeconomic indicators such as real exchange and interest rates on agricultural incentives, production decisions and agricultural policy is accompanied by examples from the literature on developed and emerging economies. Moreover, this chapter considers the effects of agriculture on the rest of the economy, taking into account the substantial role of the agricultural sector in Ukraine in terms of its contribution to GDP, balance of payments, and its importance for national employment market.

The third chapter presents the economic development in Ukraine in the course of post-independence transition (1991-2001). First, developments of the overall economy with the emphasis on fiscal, monetary, exchange rate, and trade policies are described and analysed. Then, the agricultural development in Ukraine is explained by looking at the initial conditions, changes in the farm structures, and farm support and trade policies. The former analysis is important to tackle the dynamics of the major macroeconomic 
variables to be later used in the empirical chapter. Similarly, the latter analysis helps to explain the possible feedback of the farm sector on overall economic performance in Ukraine.

In chapter four the interlinkages between macroeconomics and agriculture in Ukraine are empirically estimated. First, the impact of macroeconomic management on the real exchange rate (RER) is analysed, the estimated results of which are further used to build the indicator of the RER misalignment and to study its effects on agricultural prices and agricultural growth in Ukraine. Second, the effects of real interest rate on agricultural variables in Ukraine, such as the production costs, cost of external financing or cost of commodities' storage, are empirically estimated. Finally, the impact of agricultural performance on overall economic growth in Ukraine is discussed by looking at the farm competitiveness and its impact on the macroeconomic stability.

The conclusions of this study and policy recommendations are presented in chapter five. 


\section{Theoretical Foundations of Interlinkages between Agriculture and Macroeconomics}

\subsection{Introduction to interlinkages between macroeconomics and agriculture}

Farming is an undertaking that involves many decisions. "What crops to plant, what inputs to use, when and how to plow, seed, cultivate, or harvest, how much to keep for own consumption, how much to sell, and how much to store for later sale are farming decisions that occupy the daily routine of most agricultural producers" (TIMMER, 1998a: 125). In contrast to the planning economy where farming decisions are based on the directives of a small group of planners, in a market economy farming decisions are mainly driven by prices. Price incentives guide factor accumulation, as well as efficiency and technical change, which are key for the agricultural growth (see EVENSON, 1989; MAMINGI, 1997; MUNDLAK, 2000). For this process to work efficiently, it is essential that the price system be protected from the macroeconomic disorder.

Macroeconomic policy, therefore, plays very important role in creating conditions for sending undistorted price signals to the agricultural sector. Figure 1 demonstrates the complexity of these relationships. Some of them, such as the impact of fiscal policy on certain food programs for consumers or support programs for farmers, are straightforward. But many of them are invisible and hardly controlled by the policy makers. Liberalisation of foreign trade, for example, may encourage the imports of either cheaper or more 'qualitative' agricultural inputs, such as agricultural machinery or chemicals. Indirectly such a liberalisation would probably bring the farmers positive side effects such as a lower inflation, higher real wages, and better markets from a larger GDP. Similarly, a monetary expansion can certainly ensure a larger credit supply for farmers, but the farmers could not be isolated from the negative side effects of this expansion in the form of higher inflation and probably a RER appreciation.

Two macroeconomic fundamentals seem to be a very important in context of influencing the agriculture: real exchange and interest rates. According to VALDES (1989: 137), "real exchange rate is perhaps the most influential price affecting incentives for agriculture", while the real interest rate also cannot be ignored in such a capitalintensive sector as agriculture (see, for example, SNAPE, 1989; CRAMER et al., 1997). These variables are mostly often used in the literature on effects of macroeconomics on agriculture in both developed and developing countries since they serve as a sort of barometer of the general macroeconomic conditions. Policy makers cannot directly influence these fundamentals, but through combination of fiscal, monetary, trade, or structural policies governments can determine the direction and magnitude of movements of these variables. These movements can significantly affect farm performance through different channels. 
Figure 1: Impact of macroeconomic policy on agri-food policy

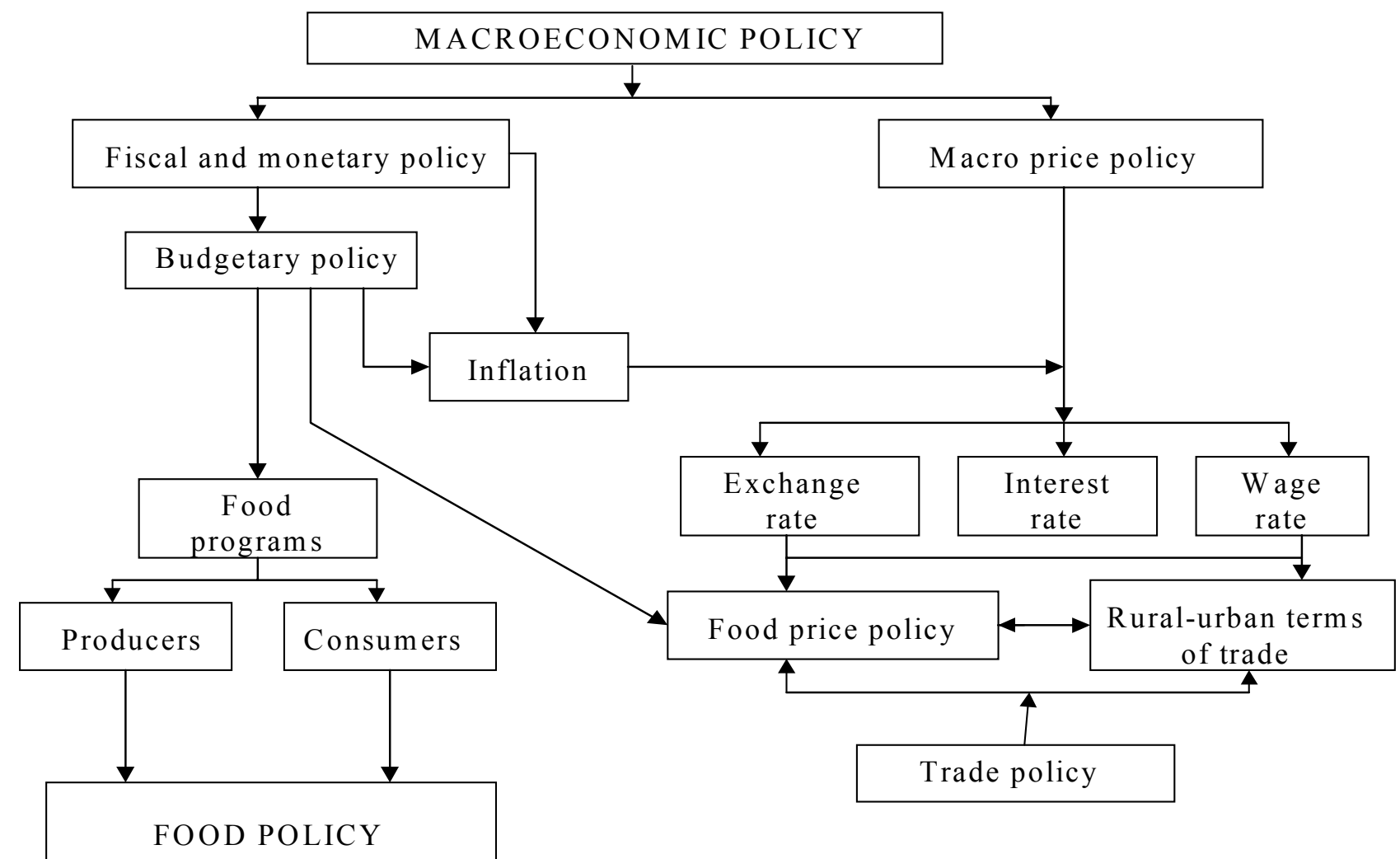

Source: TIMMER et al. (1983: 223).

In reality, figure 1 is much more complicated, because reverse effects of agricultural policy and farm performance on macroeconomics should be taken into account. This is especially the case in an economy such as Ukraine. The role of Ukrainian agriculture for overall economy could be compared with the role of farming sector in many middle-income developing countries. Ukraine's agriculture has an important status in the system of national accounts. In 2001, for example, farmers produced roughly $14 \%$ of Ukraine's total GDP, agri-food export accounted for $11 \%$ of total merchandise exports and $24 \%$ of working population were employed in the agricultural sector (SSCU, 2002). To keep figure 1 relatively simple, the impact of agriculture on the rest of the economy is demonstrated using an example of economy-wide effects of farm support policies (see figure 2). "As farm support policies are intended to transfer income from non-farmers to farmers, non-farmers are explicitly affected because of income foregone" (KOESTER, 1991: 11). The magnitude of the effects depends on the instruments chosen by agricultural policy makers. The more such distortive support instruments as price support or production quotas are used, the larger are non-farm losses incurred in the form of a higher tax burden, distorted factor use and lower international competitiveness through, for example, the RER overvaluation. "Often the indirect effects of farm support are more important than direct effects" (KOESTER, 1991: 12). 
Figure 2: Economy-wide effects of farm support policies

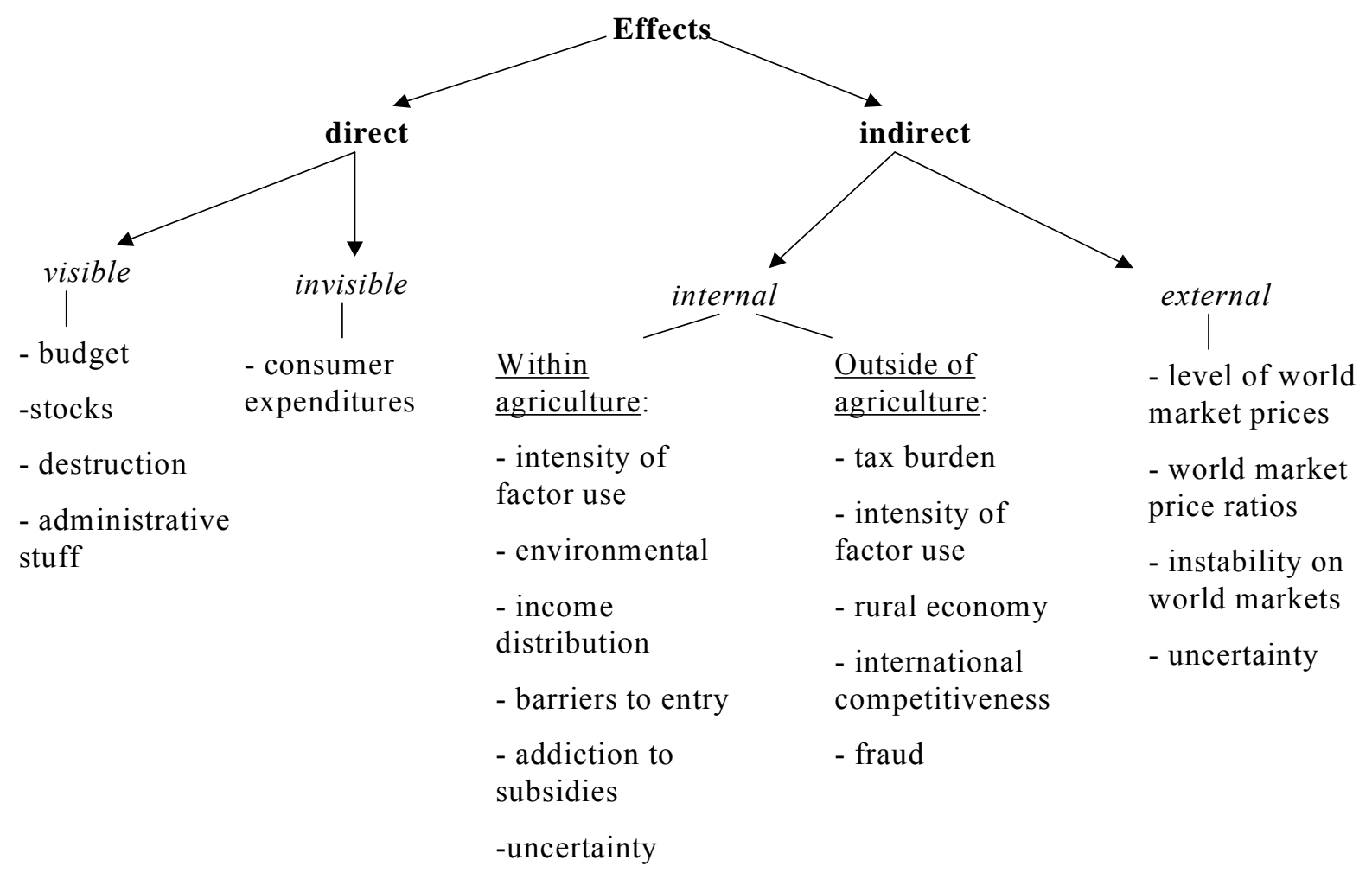

Source: $\quad$ KOESTER (1991: figure 1).

In the following sections, the interlinkages between agriculture and macroeconomics will be considered in the general equilibrium framework with deep insights into the impact of real exchange and interest rates on agriculture, as well as agriculture on overall economy.

\subsection{General equilibrium framework}

It is becoming increasingly popular to study the interlinkages between agriculture and macroeconomics using the Computable General Equilibrium (CGE) models. For example, the International Food Policy Research Institute (IFPRI) applies them to study structural adjustment programs in the developing countries (BAUTISTA et al., 1998). The CGE models are also gradually starting to be used for CEE transition economies to study, for example, the effects of the EU-East enlargement or tax reform in the Russian Federation (see, for example, WEHRHEIM and WIEBELT, 1997; BANSE, 2000)

The CGE models are the simulation type models which "describe the allocation of resources in a market economy as a result of interaction of supply and demand, leading to equilibrium prices" (BORGES, 1986: 8). Although the CGE models are very useful in modelling and studying economic interlinkages, their practical application for the transition economy such as Ukraine is not free of problems:

- "The most frequently mentioned weakness is the lack of empirical validation of the model, in the sense that usually there is no measure of the degree to which the model fits the data or tracks the historical facts" (BORGES, 1986: 19). This especially concerns the transition economies where the relationships among economic actors are highly unstable. 
- Continuing the streamline of the first problem, the CGE models are better suited to study economies where the market mechanism - even if constrained by government interventions - still remains the dominant mode for allocating resources. If all the major decisions on resource allocation are taken by the government or are not subject to competitive behaviour, which is still the case in Ukraine, the CGE models should be replaced by more appropriate and more useful models (BORGES, 1986).

- The CGE models are usually based on the certain period of time which might be called 'equilibrium' or 'sustainable'. This sustainable period is difficult to define for Ukraine simply because its economy is in the course of important continuous structural changes.

- And finally, this dissertation is targeted, to a large extent, to Ukrainian policy makers. The 'black box' of the CGE models could be a difficult framework for them to properly understand the relationships within an economy.

Although the CGE model could have been more straightforward in addressing the main objectives of the dissertation, above-mentioned problems constrain its application for Ukraine's transition economy over the last decade. The analysis of interlinkages between agriculture and macroeconomics in this dissertation, therefore, is based on a list of different methodologies within a general equilibrium framework. It gives a certain leeway in targeting every important issue separately by using various techniques. This approach also permits avoiding the bias of complex models with large data sets.

\subsection{Real exchange rate and agriculture}

The impact of the RER on agriculture is a popular topic in the economic literature. No doubt, the most important paper on exchange rates, other macroeconomic phenomena, and agriculture is the classic paper of EDWARD SCHUH entitled "The Exchange Rate and U.S. Agriculture" (see SCHUH, 1974). "What makes this paper so important is not the sophistication of the analytical argument. Rather it perceives the problem and the implications of that problem well in advance of the rest of the profession" (PAALBERG and CHAMBERS, 1988: 8). Short literature overview, presented in the dissertation for developed, developing and transition economies, is based on 'rich' literature that appeared world-wide after SCHUH's research. Theoretical foundations of effects of the RER on agriculture follow the literature overview.

\subsubsection{Literature overview}

\subsubsection{Exchange rates and agriculture in developed economies}

The relationships between the RER (and other macroeconomic variables) and agriculture is studied most intensively for the United States. The nature of the relationship between the macroeconomics and relative prices in agriculture for the U.S. was analysed in details by SCHUH $(1974 ; 1989)$. The basic idea of SCHUH's papers is that the U.S. exchange rate policy during the post-war era had effectively taxed agricultural exports, thus, tending to diminish agricultural exports, agricultural prices, agricultural incomes, returns to farm labour, and ultimately agricultural land values. He also used an induced-innovation hypothesis in combination with an overvalued exchange rate to 
partially explain a shift away from land-intensive cultivation practices to capital-intensive practices in the United States.

SHANE (2001) indicates that historically shifts of exchange rate have accounted for approximately $25 \%$ of the change of the U.S. agricultural export value. Other factors, such as income growth rate in developing countries, growth and productivity of foreign agricultural sectors that compete with the United States and weather conditions accounted for much of rest. Since 1995 the appreciation of the U.S. dollar has become a handicap for the U.S. agricultural exports. According to the author, appreciation of the dollar was a major factor in 2\% decline in global share of all U.S. agricultural exports between 1992 and 1998. From a peak of nearly US\$60 bln (\$) in fiscal 1995, the U.S. agricultural exports declined to \$49 bln in 1999.

ChAmBers and JUST (1981) found that the level of the U.S. grain exports had been very sensitive to fluctuations in the exchange rate. The estimated price elasticity equalled 0.5 , though the elasticity varies among different commodities. In the case of the appreciation they found that "... for all markets exports increase rapidly and then decline somewhat after several quarters. The continued high level of exports is then sustained partially by a long-term declining trend in inventories" (cited in KUHL, 1998: 57).

Although the RER appreciation has a negative direct impact on agricultural exports, the importance is not in appreciation per se, but rather in its sustainability. If the RER appreciates to its new lower equilibrium level, it brings the positive signals to the farmers in the form of lower interest rates and higher productivity growth in the non-farm sector with a more robust domestic market. The experience of the United States is also interesting in this respect. During the both 1980s debt crisis and recent financial crises in Asia, Russia and Brazil, the farming sector experienced a high-valued dollar. However, other economic policies made a difference. The 1980s saw a tight monetary policy with high interest rates, high inflation and a weak domestic banking system - in sharp contrast to the situation when the Asian financial crisis hit in 1997. Although the last financial crisis did indeed result in a higher-valued dollar, its rise was brief, small, and not associated with higher interest rates, which could have pushed the value of dollar even higher. "Large amounts of capital flowed into the United States in the aftermath of the financial crises, credit continued to be readily available, and interest rates were lower than before the crises. Changes in the structure of U.S. agricultural trade from recent macroeconomic realignment have been subtle. Lower export receipts for farmers were partly offset by cheaper capital and inputs and a more robust domestic market" (TORGENSON and HAMREK, 2000: 65).

As with the U.S. farmers, exchange rate issues were always important for European farmers as well. They were even more complicated taking into account the agri-monetary system (AMS) - an important facet of the EU's Common Agricultural Policy (CAP). Until 1999, agri-monetary issues were always at the top of the CAP agenda, and served as a mechanism to compensate farm price decrease in the countries with revaluated currencies and to protect farm prices from the exchange-rate fluctuations. The AMS was often revised. For example, during 1962-1999, the units of account included gold parity unit of account, joint float of account, ECU, and agricultural or green ECU (VON CRAMON-TAUBADEL, 1994). Use of these special agricultural exchange 
units isolated the EU farmers from the market exchange rate fluctuations and thus, distorted relative price incentives for farmers in the member states.

The introduction of Euro $(€)$ on January 1, 1999 liquidated the previous system of the special agricultural exchange rates, but it opened an era of new challenges. The most actively discussed link between the exchange rate and the agriculture in Europe is the costs of the CAP financing. A substantial part of the CAP budget expenditures is directed to the financing of the export subsidies. The value of the export subsidies depends on the difference between the world market prices (usually denominated in \$) and internal EU prices(denominated in $€$ ). In 2001 and 2002, the $€$ was weak vis-a-vis the $\$$ (meaning that the difference between world and internal EU prices was lower) that allowed the European Commission to make considerable budget savings (see AGRITRADE, 2002).

For EU countries, which did not join the Euro zone yet, changing exchange rates continue to influence the farmers. For example, in the United Kingdom, the strong pound is called to be a serious problem for farmers (FT, 2001). During 1995-2000 the real exchange rate against $€$ appreciated by about 35\% (IFS, 2002), and the exchange rate effects seem to be significant not only due to the lower farm output prices, but also due to the lower subsidies values initially denominated in $€$, and then exchanged into sterling (though these negative effects are partially compensated through lower farm input prices). Articles stating that "with milk prices at a 15-year low, and beef and sheep sectors suffering from the strength of sterling, the UK livestock producers have a justifiable case to get the EU compensation" (FT, 2002), therefore, are not seldom.

\subsubsection{Agriculture and real exchange rate in developing countries}

Literature on an impact of the RER on agricultural development in developing countries richly covers Latin America, Africa, and Asia. Early discussions of the bias against agriculture as a result of industrialisation policies pursued by developing countries is found in DiAZ-ALEJANDRO (1970) and LITTLE et al. (1970). "In the 1960-70s the agrarian society by its very nature was regarded as socially and economically backward, governed by tradition, impervious to market signals, and devoid of links to other sectors that could bring the benefits of progress in agricultural production to the economy as a whole" (SCHIFF and VALDES, 1999: 4). Industrialisation policies, therefore, were aimed at achieving a long-term economic growth (see also JOHNSON, 1993b). DIAZALEJANDRO used relative prices to examine the impact of industrial protectionism on agriculture in Argentina during 1930-1964. He found that significant bias against agriculture was mainly a result of domestic policies. LITTLE at al. compared domestic value-added and value-added at world prices in seven developing countries in the 1950s and 1960s. "They found in several countries extremely high levels of manufacturing protection, e.g. 313\% in India in 1961 (the lowest being 27\% in Mexico in 1960). In four of the seven cases, nominal protection exceeded $100 \%$, far higher than could be justified by those who argued in favour of protection of infant industries" (cited in SCHIFF and VALDES, 1999: 14).

In the early 1980s, influenced by the work of SJAASTAD (1980), the Trade Policy Program at the IFPRI adapted and extended the 'true protection' approach to analyse the issue of how industrial policies affected the price of agricultural tradables relative to non- 
tradable goods. On the premise that an import tariff is an implicit tax on exports (the Lerner Symmetry Theorem ${ }^{1}$ ), SJAASTAD derived an incidence parameter $\omega$, that measured the effect of an increase of import prices on the domestic price of nontradables. When the government sets high import tariffs to protect its industry, domestic prices for imports raise. That shifts consumer demand away from imports, resulting in excess demand in the other sectors. Partially consumer demand is shifted to nontradables, inducing a rise in their prices. The multiplier of the demand shifting (or incident parameter $\omega$ ) reflects the propensity to spend on non-tradables when the import prices raise. A growth of prices of non-tradables is accompanied by a decrease in the relative prices of the unprotected tradables (for example, exportables). Therefore, SJAASTAD stated that import tariffs had similar effects on exporters, comparable to export taxes. The equation that SJAASTAD used in his empirical estimation was:

$$
\ln \left(P_{N} / P_{x}\right)=\alpha+\omega \ln \left(P_{m} / P_{x}\right)
$$

where $\omega$ ("incidence" parameter) reflects proportional change of non-tradable goods price relative to exportables as a function of proportional changes of the price in importables relative to exportables, $P_{N}$ is the price of non-tradable goods, $P_{x}$ is the price of exportables, $P_{m}$ the price of importables, and $\alpha$ is a constant.

Table 1 presents the estimation of the incidence parameter $(\omega)$ found in several studies. These studies report a high level of substitution between non-tradable goods and importables, implying a strong negative impact on relative price of exportables to nontradable goods. If $\omega$ equals to 0.6 , a $10 \%$ increase of importables price is associated with a $6 \%$ decline in the domestic price of exportables (mainly agricultural products in these countries) relative to home goods.

Table 1: Estimates of the incidence parameter $(\omega)$ as it affects agriculture

\begin{tabular}{lcc}
\hline Country & Author & Value of $\boldsymbol{\omega}$ \\
\hline \hline Argentina & Sjaastad & 0.4 to 0.5 \\
Chile & Sjaastad & 0.5 to 0.6 \\
Colombia & Garcia & about 0.9 \\
Nigeria & Oyejide & 0.6 to 0.9 \\
Peru & Valdes & about 0.7 \\
Philippines & Bautista & about 0.8 \\
Zaire & Tshibaka & about 0.8 \\
\hline
\end{tabular}

Source: $\quad$ SCHIFF and VALDES (1999: 15).

Finally, KRUEGER et al. (1988) and SCHIFF and VALDES (1992) adapted an 'elasticity' approach to exchange rate determination in conjunction with an explicit

\footnotetext{
${ }^{1}$ The Lerner (also called Marshall-Lerner) theorem states the elasticity conditions under which a change in a country's exchange rate would improve its balance of trade. The rule states that the price elasticities of demand for imports and exports must sum to greater that unity for an improvement to be effected. If the price elasticity of exports plus the price elasticity for imports is less than unity, it means that the increased cost of imports in terms of the domestic currency outweighs the value of the growth of exports.
} 
treatment of non-agricultural prices. These works explored the combined effect of direct (sector-specific) and indirect (economy-wide) policies on agriculture in a sample of eighteen developing countries. The authors found that indirect taxation generally exceeded direct taxation. The total taxation of studied countries equalled $30 \%$, with $8 \%$ of direct price interventions toward agriculture, and $22 \%$ of indirect taxation through macroeconomic policy and often overvalued RER (see table 2). The authors also found that high taxation of agriculture was associated with low growth of agriculture and of the whole economy. This so-called KRUEGER-SCHIFF-VALDES approach is used in this dissertation to study the direct and indirect effects of macroeconomic policy (mainly the RER) on agricultural incentives in Ukraine (see section 2.3.3), though the estimation of the RER equilibrium differs from authors' original approach.

Table 2: Direct and indirect rates of nominal protection, 1960-1984, period average in $\%$

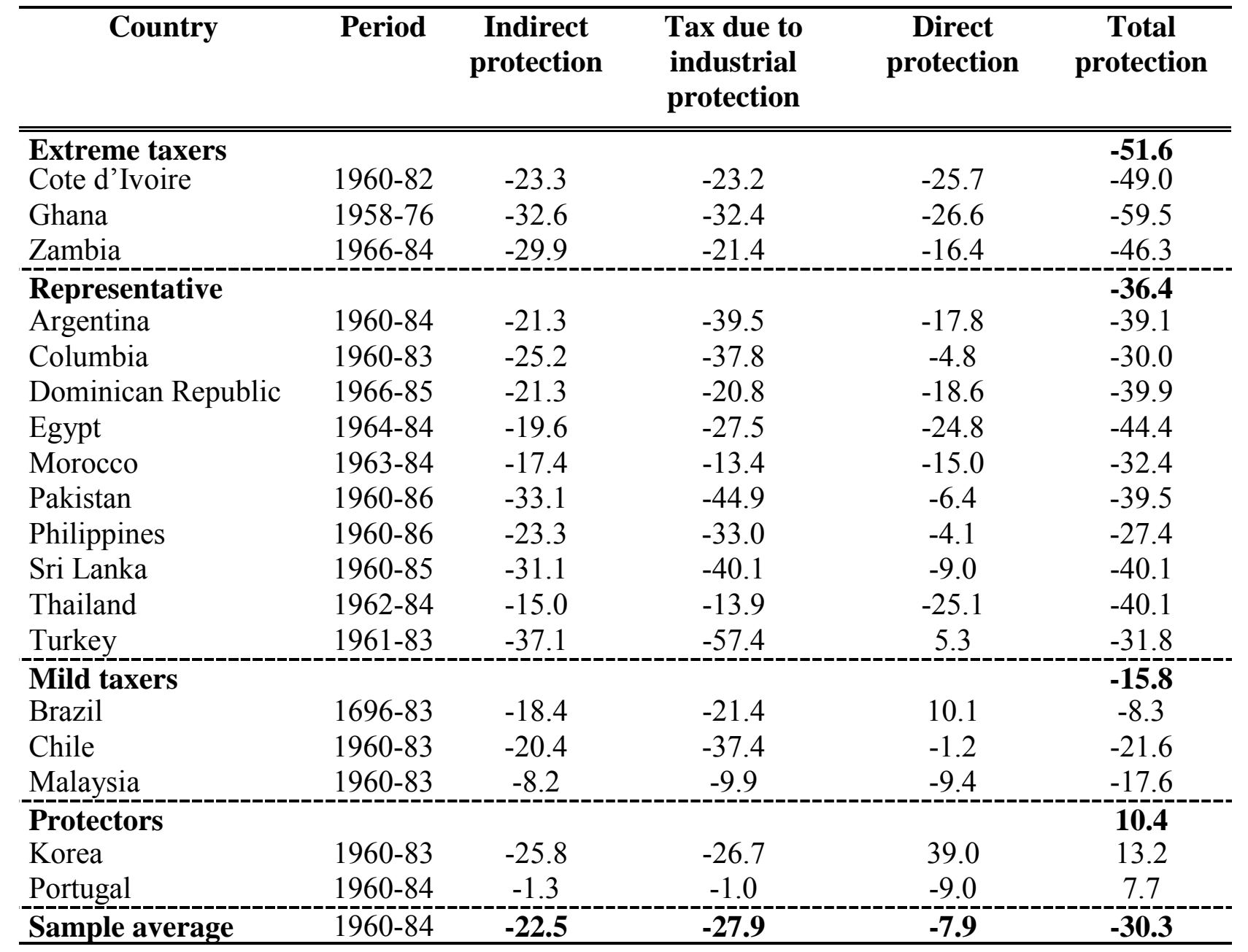

Source: SCHIFF and VALDES (1999: 20). 


\subsubsection{Agriculture and exchange rates in transition economies}

In comparison to the literature on developed and developing economies, there is little applied research on studying a dependence of agricultural development on exchange rate management in the CEE transition economies. This is especially surprising taking into account the vast macroeconomic changes in these countries over the last decade. ${ }^{2}$ One study with respect to the RERs and agriculture in the CEE countries was written by BOJNEC et al. (1997). The authors used different approaches to estimate the equilibrium RER (purchasing power parity (PPP) and Big Mac PPP index ${ }^{3}$ ) and simulated EU accession scenarios under different exchange rate assumptions. They demonstrated how much agricultural price distortions, protection rates and budgetary costs of EU accession in the CEE countries depended on these exchange rate assumptions and recommended the policy makers to account for changes in the RER in designing agricultural policy.

Second study in this context considered the impact of different variables (including the RER) on agricultural protection in several CEE countries. HARTELL and SWINNEN (2000) explained the level of agricultural protection defined in terms of the Producer Subsidy Equivalent (PSE) to be dependent upon RER, relative income, structure of the economy, net agricultural trade position, and institutional structure in Estonia, Czech Republic, Hungary, Poland, Slovenia, and the Slovak Republic for the period 1992-1996. The authors have found that changes in the RER had a statistically significant and large impact on the level of agricultural protection and that lower RERs in the studied countries were usually associated with higher farm support.

The impact of financial crisis on agriculture in the Eastern Europe becomes a popular issue especially after the recent 1997-1998 financial crises in East Asia, Russia, and Brazil. According to the USDA/ERS, the Russian crisis generated large-scale capital flight, depreciation of the rubble against the U.S. dollar from August to December 1998 of about $75 \%$, high inflation (120\% from August 1998 to July 1999), and falling GDP (a drop of $5 \%$ in 1998). The crisis reduced demand for food as well as lowered food consumption for two reasons: (1) substantial depreciation of the rouble raised domestic prices for foodstuffs and (2) the crisis reduced consumer wealth and income. However, the crisis helped rather than hurt Russian agriculture. Rouble depreciation has improved the price competitiveness of the Russian economy, and although the depreciation has also raised prices for some tradable agricultural inputs which by increasing production costs hurts producers' competitiveness, these inputs account for only a certain fraction of the value of most of agricultural outputs. From August 1998 to spring 1999, Russian agriculture's terms of trade improved about 35\% (LIEFERT, 2000).

\footnotetext{
2 Actually first thoughts on the RER in transition economies were related to the discussion whether agriculture in these countries was effectively subsidised or taxed under the central planning.

3 The Economist's Big Mac index was originally introduced as a bit of fun and "to make economic theory more digestible" (The Economist, April 27, 1996), but later it has inspired several serious studies. The Big Mac Index uses as basket the McDonald's Big Mac, which is made to roughly the same recipe in more than 80 countries. The Big Mac PPP is the exchange rate what would make a burger cost the same in America as it does abroad.
} 
A word-wide literature on importance of the RER for agricultural development implies a high importance of this issue for Ukraine. To understand the intersectoral linkages and resource flows through the impact of the RER, the next section presents the DEPENDENT ECONOMY MODEL (DEM).

\subsubsection{Dependent Economy Model}

The DEM is derived from the works of Australian economists MEAdE, SALTER and SWAN. This model was extended and now is extensively used to analyse trade and exchange rate issues. ${ }^{4}$ Before presenting the DEM, the difference between nominal and real exchange rates is defined.

Exchange rate plays a very important role in determining agricultural competitiveness through output/input price and resource allocation effects. In this context the real exchange rate is usually considered instead of nominal exchange rate (NER). Although the concept of NER is very important in analysing exchange-rate-regimes or debt issues (EDWARDS, 2000), RER is used in the analysis of competitiveness or macroeconomic equilibrium issues (HELMERS, 1988). Changing the exchange rate alters the relationship between domestic and foreign prices, and so does inflation, at home and abroad. The concept of RER attempts to adjust nominal exchange rates for relative inflation to determine the combined effect on incentives to produce, purchase and hold. In general, RER absorbs all important internal and external shocks in the economy and, therefore, it, to the large extent, reflects the quality of economic policy (MOELLERS and SIEDENBERG, 1999).

There is no universally accepted definition of the RER and the choice between the concepts depends partially on the immediate reasons for comparing them. In this thesis, the definition of the RER given by SEBASTIAN EDWARDS is used where the RER is defined as a ratio of prices of tradables to those of non-tradables (EDWARDS, 1989). Tradable goods are those traded internationally, for example, grain, fertilisers, cars or oil. Non-tradable goods are mainly 'services', such as construction, communication, transportation, financial and other services that are available only on the domestic market. An increase of RER (its depreciation) ensures better price ratio for tradable goods, while a decrease of RER (its appreciation) improves the relative position of the non-tradable goods sector through higher relative prices of these goods. As agriculture is a sector that produces mainly tradable goods, depreciation (appreciation) of the RER has a significant impact on competitiveness of agricultural exports, real agricultural prices and consequently, growth. MUNDLAK (1989: 34) states that "in principle, all agricultural products are tradable, and if they are not traded, it is because the domestic price lies in the interval formed by export and import prices of the given product, where width of the interval reflects the cost of transportation, broadly interpreted. Variations in world prices and in transportation costs may convert a product non-traded to be traded, or visa versa".

Basic assumption of the DEM model is a small open country producing two types of goods, i.e. tradables and non-tradables. Generally, this economy consumes

\footnotetext{
${ }^{4}$ See original model in Meade (1951), Salter (1959) and Swan (1960) and for further applications see DORNBUSCH (1980), DORNBUSCH (1988a).
} 
domestically produced goods and imported ones $(M)$. The importables are a substitute for domestically produced goods and that is why the domestic production is importcompeting. The level of exports $(X)$ is determined by excess supply of the exportable tradable goods over their domestic consumption. For simplicity it is assumed that all three goods are final products so as not to complicate the model with the intermediate goods. In the model exportable and importable goods are aggregated into the total tradables $(T=X+M)$. The non-tradable goods $(N)$ are confined only to the domestic market.

The prices of the tradable goods $\left(P_{X}^{*}\right.$ and $\left.P^{*}{ }_{M}\right)$ are determined exogenously in the world markets, and the assumption of a small open economy implies that a country has no influence on them. ${ }^{5}$ Moreover, the nominal exchange rate and the relevant trade policy instruments influence the domestic prices of the tradable goods. Domestic prices of the imported goods are defined as

$$
P_{M}=E P^{*}{ }_{M}\left[1+t_{M}\right]
$$

where $E$ is the nominal exchange rate and $t_{M}$ is the implicit tariff rate which would be negative in case of an import subsidy. Similarly

$$
P_{X}=E P_{X}^{*}\left[1-t_{X}\right]
$$
subsidy.

where $t_{X}$ is the export tax, similarly this would be positive in the case of an export

Prices of the domestically produced non-traded goods $\left(P_{N}\right)$ are solely determined by domestic supply and demand, as well as by production costs and fiscal and monetary policy instruments that have impact on domestic prices. Finally, the model makes the traditional neo-classical assumptions concerning flexibility of the prices and wages, as well as the full employment. "This assumption can be relaxed on the premise that any rigidity in the non-tradable price, for instance, will result in excess supply of $N$ and consequently unemployment" (see CORDEN, 1997: 263). Capital is assumed to be sectorfixed at least in the short run and the major mobile factor in the model is labour.

To derive the equilibrium properties of the model, prices of exportables and importables are combined in one composite tradable good $(T)$ with the price determined by the following equation:

$$
P_{T}=\eta P_{M}+[1-\eta] P_{X}
$$

where $\eta$ is a share of importables in the tradable goods.

This aggregation enables the derivation of the key variable of interest in the model, i.e. the RER (e) which is defined as a ratio of relative prices of tradables to those of non-tradables, i.e. similarly to above EDWARDS's definition:

$$
e=P_{T} / P_{N}
$$

Overall equilibrium condition of the model requires a simultaneous achievement of the external and internal equilibrium, i.e. equilibrium in the tradable and non-tradable markets. The equilibrium in the non-tradables market holds when demand for non-

\footnotetext{
${ }^{5}$ An asterix (*) on a variable denotes foreign prices.
} 
tradable goods clears their supply (in this situation the economy is in full employment). The demand for non-tradables $\left(D_{N}\right)$ is a function of the RER and a domestic absorption $(A)$, which is in turn defined as a sum of domestic private consumption $(C)$, investments $(I)$ and state consumption $(G)$. A rise of the RER (or its devaluation) makes the nontradables cheaper compared with the tradables (see equation (2.4)) and thus leads to an increase in its demand. A drop of the RER, i.e. the RER appreciation, initiates the converse and decreases the demand for non-tradables in relation to tradables. This holds only if the negative income effect of the price change dominates over an accompanying positive substitution effect (CORDEN, 1997). The demand for non-tradables is defined as follows:

$$
D_{N}=D_{N}\left(P_{T} / P_{N}, A\right)
$$

The supply of non-tradables $\left(S_{N}\right)$ is a function solely of the RER - a rise in the RER incurs a decline of the production of the non-tradable goods as a response to the lower relative prices $P_{N}$. Based on an earlier mentioned assumption about price flexibility, the market is a subject to the strict equilibrium at any point of time, i.e. the market of non-tradables always clears.

$$
S_{N}=S_{N}\left(P_{T} / P_{N}\right)
$$

Figure 3 demonstrates the $\mathrm{NN}$ curve with various possible combinations of domestic absorption and RER. The negative slope of the curve shows the negative relation between RER and non-tradables. A real appreciation will lead to an excess supply of the non-tradable goods, but the magnitude of this excess depends on the substitutability between tradable and non-tradable goods. At a constant level of absorption, a real appreciation will cause the supply of non-traded good to rise and its demand to fall. Therefore, equilibrium can only be maintained if the level of absorption adjusts (increases) to make up for the change in the RER. Points above the $N N$ schedule correspond to an excess demand for non-traded good, and conversely points below the schedule reflect an excess supply of them. 


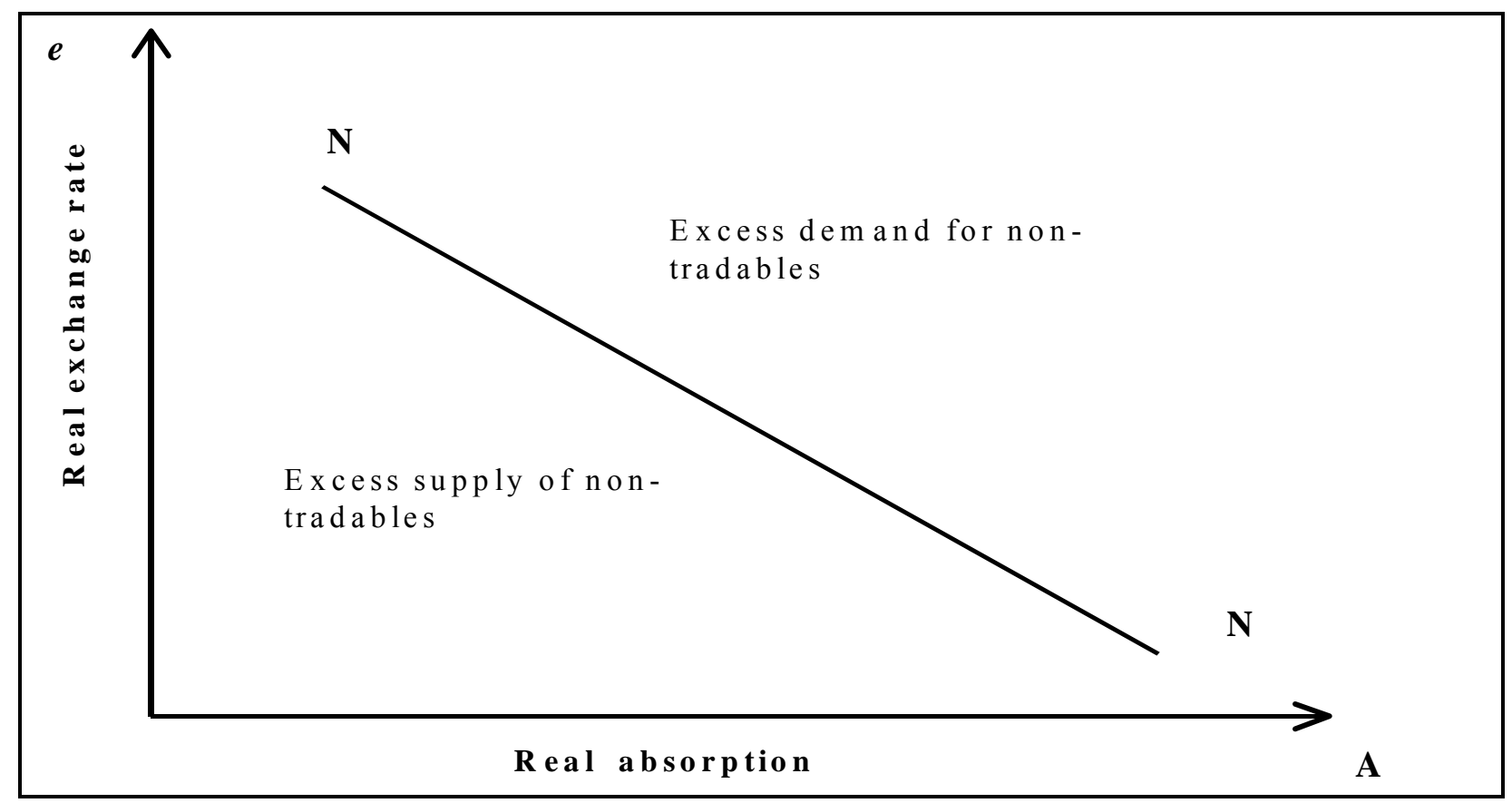

Source: $\quad$ Adapted from SwAN Diagram (1963).

Equilibrium in the tradables market is similarly derived from the supply and demand status in the market. The demand for tradables $\left(D_{T}\right)$ is affected by changes in the RER and in domestic absorption. RER devaluation makes tradables more expensive for domestic consumers, inducing lower consumption of the tradables. A fall in the relative price equally initiates the reverse.

$$
D_{T}=D_{T}\left(P_{T} / P_{N}, A\right)
$$

A supply of tradables $\left(S_{T}\right)$ is determined mainly by the RER. The RER determines the relative profitability of the production of tradables and consequently the movement of production factors between two sectors.

$$
S_{T}=S_{T}\left(P_{T} / P_{N}\right)
$$

An equilibrium condition in the tradables market is not so strict as in the nontradables one. In the former, the external balance $(T B)$ is allowed to deviate from its equilibrium in the short run, because in reality short-term deviations could be, and often are financed via capital inflows, temporarily excluded from the model for simplicity. In the long run, however, trade deficits or unsustainable imbalances are not allowed. An equilibrium condition in the tradables market can be represented as

$$
T B=S_{T}\left(P_{T} / P_{N}\right)-D_{T}\left(P_{T} / P_{N}, A\right)
$$

Figure 4 shows the situation in the tradable goods market (curve TT) and, similarly to figure 3, it demonstrates all possible combinations of the RER and levels of domestic absorption. $T T$ is positively sloped since a rise of the RER (depreciation) causes an increase of the tradable goods' supply and, simultaneously, decreases its demand. This results in a trade surplus or overall disequilibrium that can be restored by increasing real spending on tradable goods. Points above the $T T$ schedule correspond to a trade balance surplus while points below correspond to a deficit. 


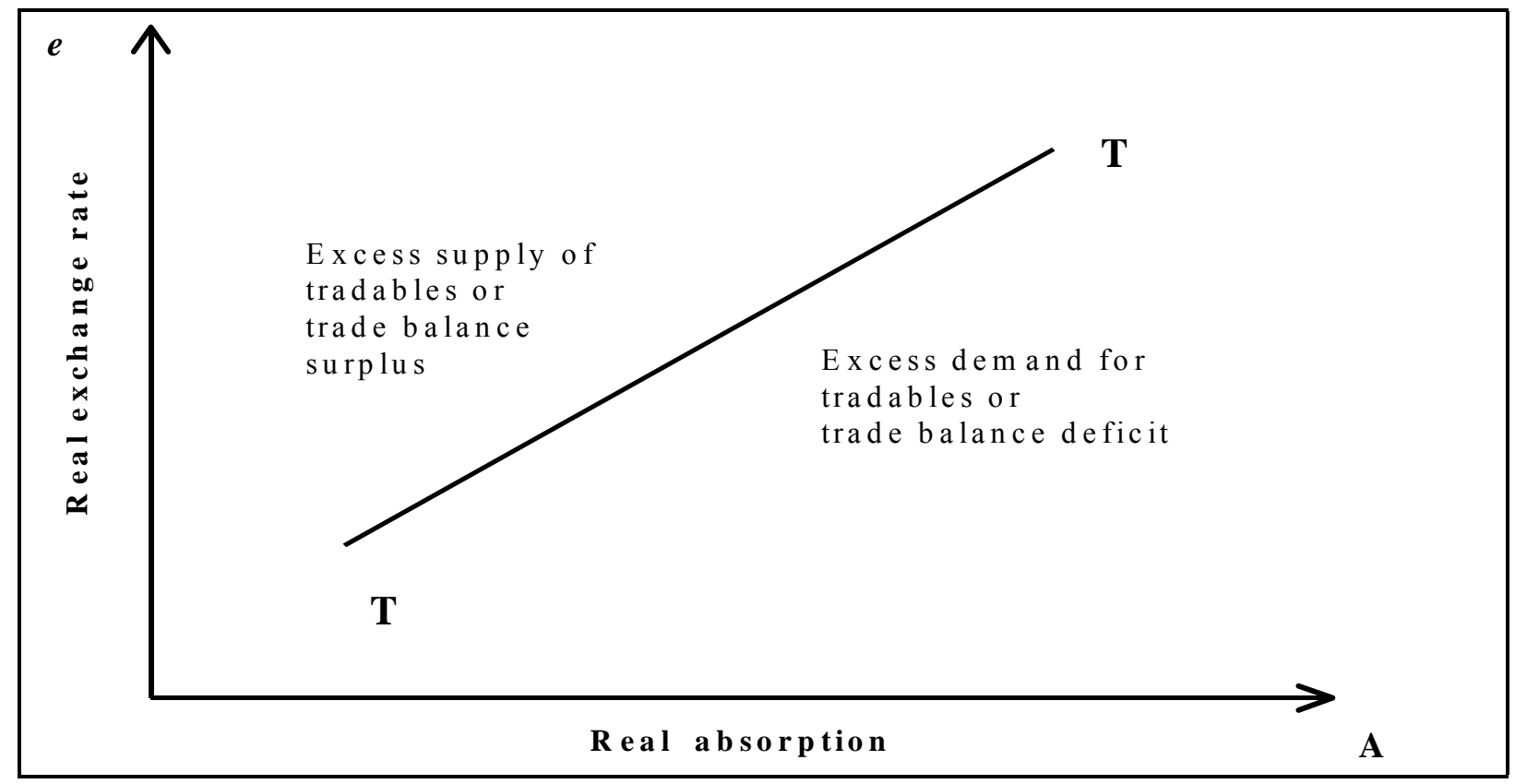

Source: $\quad$ Adapted from SwAN Diagram (1963).

Overall equilibrium in the economy is attained by deriving aggregated supply and demand equations. Total production in the economy $(Y)$ represents the output of tradable $\left(\mathrm{S}_{T}\right)$ and non-tradable $\left(\mathrm{S}_{N}\right)$ sectors. Measured in terms of the non-tradable goods this can be expressed as

$$
Y=S_{N}\left(P_{T} / P_{N}\right)+e S_{T}\left(P_{T} / P_{N}\right)
$$

Total supply is determined by the output of both goods and the RER depreciation (a rise in prices of tradables) is expected to increase the supply of tradables through both income and substitution effects. It is also expected to reduce the supply of non-tradables because of the dominance of the substitution over income effects (CORDEN, 1997).

Total absorption $(A)$ in the economy is derived from the demand functions for tradable and non-tradable goods:

$$
A=D_{N}\left(P_{T} / P_{N}, A\right)+e D_{T}\left(P_{T} / P_{N}, A\right)
$$

An overall equilibrium condition, therefore, is attained when total income and total absorption are equal. The overall equilibrium is attained through the clearance of both markets with the help of the RER and the switch of absorption between goods:

$$
Y-A=\left(S_{N}-D_{N}\right)-e\left(S_{T}-D_{T}\right)
$$

The overall equilibrium in the DEM is graphically shown in figure 5 . In figure 5 the schedules $N N$ and $T T$, along which the non-tradable goods market and trade balance, respectively, are in equilibrium. Full equilibrium is obtained at point $S$ where there are both internal and external balances, and where, accordingly, income equals the expenditures. Anywhere north-west of $S$, for example, there would be trade balance surplus and anywhere south-west of it there would be insufficient demand for nontradable goods. 
Deviations from the point $S$ are grouped into four zones which are called by SwAN "Zones of Economic Unhappiness" (SWAN, 1963). In Zone I there is a trade surplus and excess demand for non-tradable goods. In Zone II there is a trade balance surplus and insufficient demand for non-tradable goods. In this situation, the most probable outcome is a rise of domestic unemployment. In Zone III there is a trade balance deficit and unemployment and in Zone IV, a deficit and excess demand for domestic non-tradable goods.

Figure 5: Overall equilibrium in the DEM

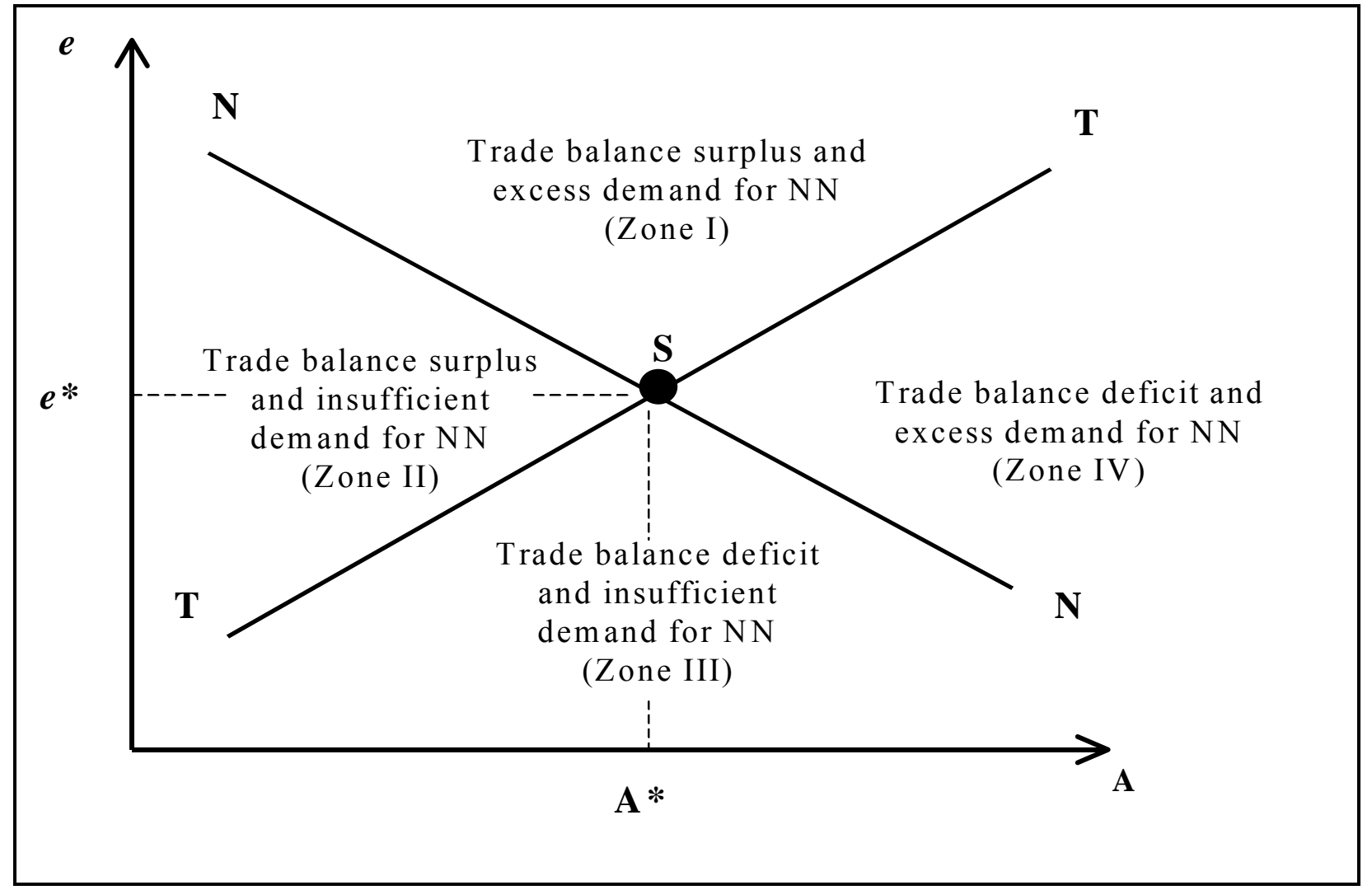

Source: $\quad$ Own presentation based on SwAN (1963).

An adjustment mechanism in SWAN diagram is presented by considering any point in Zone IV, for example. If an economy is in Zone IV, there is a trade balance deficit and excess demand for domestic non-tradable goods. The most probable reason of such an imbalance is a temporary inflation shock under a fixed exchange rate regime. Let us consider the adjustment mechanism without capital inflows first. As higher domestic inflation pushes $T T$ schedule to the right $\left(T_{1} T_{1}\right)$, the equilibrium temporary shifts to the point $S_{l}$ (see figure 6). As the capital inflows are excluded, there is no source to finance a resulted trade deficit. The RER appreciates (drop from $e_{0}{ }^{*}$ to $e_{1}{ }^{*}$ ). At this point, the nontradables market is also in disequilibrium with an excess supply of non-tradable goods. It is cleat that this new equilibrium is not long living. To restore an initial equilibrium, expenditure reduction and expenditure switching are required at the same time. An expenditure reduction causes a domestic absorption to shrink from $A_{0}^{*}$ to $A_{2}^{*}$. This brings economy to the point $S_{2}$ where the trade deficit is eliminated. As a real devaluation switches the expenditures from tradable to non-tradable goods, the initial equilibrium is restored. 
Figure 6: Adjustment mechanism in the Figure 7: Adjustment mechanism in the DEM: elimination of excessive inflation

DEM: elimination of excessive inflation with capital inflows

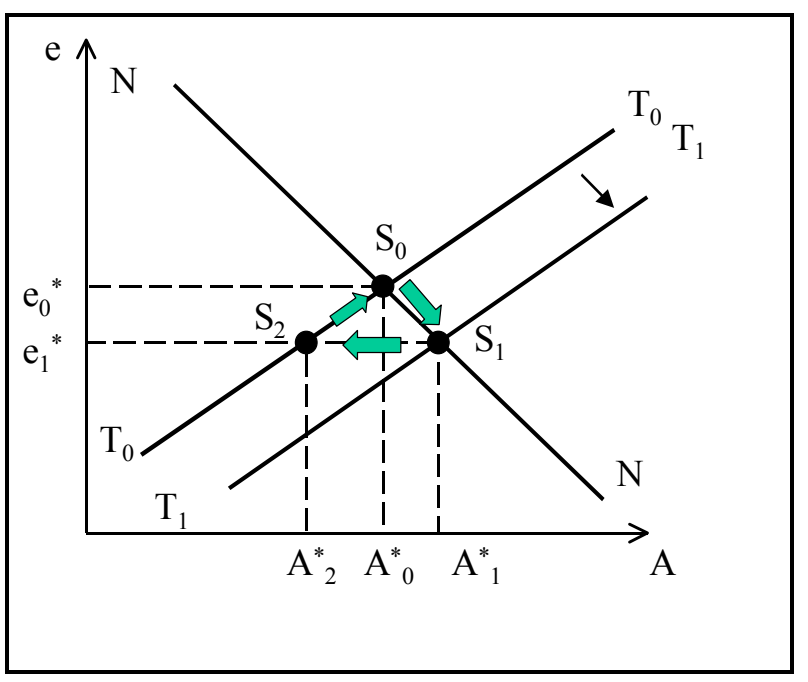

Source: Own presentation.

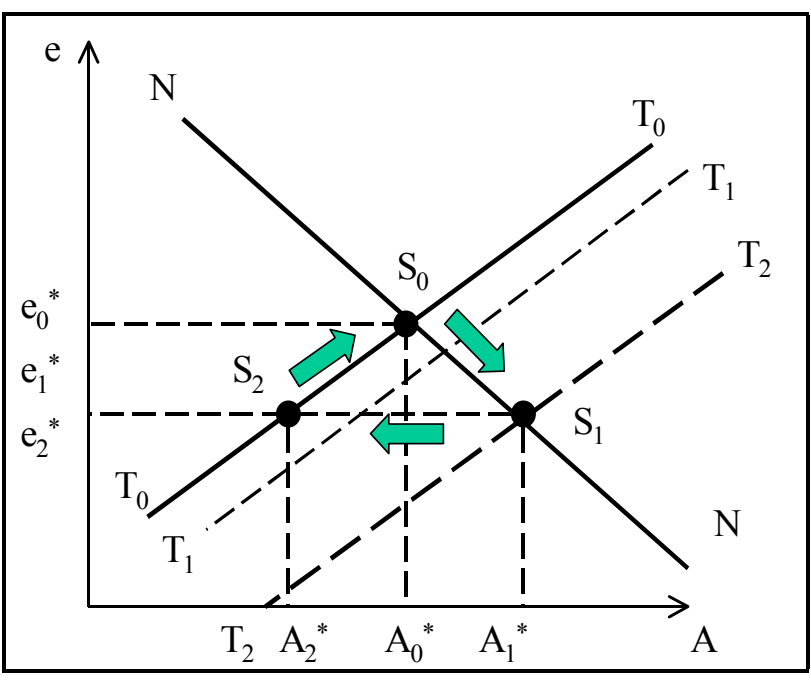

Source: Own presentation.

The case with capital inflows starts with the same initial equilibrium at point $S_{0}$ before the temporary shock takes place. In the tradables market in response to the shock, the $T T$ schedule moves to $T_{2} T_{2}$ (through $T_{1} T_{1}$ ) and the economy reaches a new equilibrium point $S_{l}$. In contrast to the situation in figure 6 , at this point the new appreciated RER is maintained $\left(e_{2}^{*}\right)$, because the trade deficit is financed through the capital inflows. If this equilibrium is sustainable, the population is better off due to higher incomes and lower price levels.

However, if the trade deficit is structural and capital inflows are short-term, the capital will probably flow out in a certain time. A very large contraction in the domestic absorption (from $A_{1}^{*}$ to $A_{2}^{*}$ ) and real devaluation (from $e_{2}^{*}$ to $e_{0}^{*}$ ) will be required to restore the equilibrium (first the movement from $S_{1}$ to $S_{2}$ and then to $S_{0}$ ). The painful adjustments in terms of expenditure reduction and real devaluation in the case with capital inflows are much larger than without inflows. The case with capital inflows, therefore, demonstrates an importance of pursuing a sound macroeconomic policy to avoid large temporary capital inflows, but rather to attract sustainable long-term inflows such as foreign direct investments, which move the equilibrium RER to a lower sustainable level.

Based on the DEM foundations, it is evident that the RER would substantially influence agricultural development in transition economies through setting price incentives and driving a transfer of factors among different sectors of the economy. Most CEE transition economies experienced an initial RER depreciation aimed to correct depressed output and assets prices after cancellation of the large subsidies, and then a strong RER appreciation. In some countries that appreciation was driven by productivity increases and positive structural changes, while in others by macroeconomic mismanagement (see HALPERN and WYPLOSZ, 1996; LINNE, 1998; ROUBINI and WACHTEL, 1998; GERLOFF, 2001). The financial crisis in Asia and Russia in 1997-1998 forced many countries, including Ukraine, to give up fixed exchange rates and made 
them more attentive to the requirements of the open economy rules. All these changes of exchange rate in transition economies aggravated the usual problems met by farmers in the developed countries. The following section will link the RER and agricultural incentives (i.e. relative prices) in a small open economy.

\subsubsection{Krueger-Schiff-Valdes approach}

As was mentioned in section 2.3.1.2 above, the KRUEGER-SCHIFF-VALDES methodology on linking the agricultural incentives with macroeconomic policies is used in this dissertation (see KRUEGER et al., 1988; SCHIFF and VALDES, 1992; BAUTISTA and VALDES, 1993; SCHIFF and VALDES, 1999). Taxation or support of agriculture is measured by both nominal (NPR) and effective (EPR) protection rates with an inclusion of the macroeconomic variables such as the RER and industrial import protection. There are no distinct differences between methodologies: while in the former relative output prices are considered, in the latter - value-added. The EPR analysis is especially useful in the context of transition economies where the dynamics of value-added could significantly differ from price developments, mainly because of intensive government interventions into input markets and farm inefficiencies. BAUTISTA et al. (1998: 1), for example, found that "effective protection of industrial products in the developing countries was often much higher than indicated by nominal protection rates, and the costs of interventions were shown to be very high indeed". Therefore, in the empirical part of the thesis both protection rates are used to estimate the level of total agricultural protection (or taxation) for Ukraine. But here only the NPR is used to present the KRUEGER-SCHIFF-VALDES approach.

Direct nominal protection rate is estimated as

$$
N P R_{D}=\frac{\frac{\left[P_{d}-P_{w}\right]}{P_{n a}}}{\frac{P_{w}}{P_{n a}}}=\frac{P_{d}}{P_{w}}-1
$$

where $P d$ is farm-gate (domestic) price for agricultural tradable product; $P w$ is border price $P_{b p}$ converted into local currency at the official nominal exchange rate $E_{0}$ and adjusted for marketing, transport, and other costs, so that $P w=E_{0} P_{b p}$; and $P_{n a}$ is non-agricultural price index, which consists of a tradable share $\beta$ with a price $P_{n a T}$ and of a non-tradable share $1-\beta$ with a price $P_{n a N T}$, so that $P_{n a}=\beta P_{n a T}+[1-\beta] P_{n a N T}$.

Indirect nominal protection rate would be

$$
N P R_{I}=\frac{\frac{P_{w}}{P_{n a}}-\frac{P_{w}^{*}}{P_{n a}^{*}}}{\frac{P_{w}^{*}}{P_{n a}^{*}}}=\frac{\frac{P_{w}}{P_{n a}}}{\frac{P_{w}^{*}}{P_{n a}^{*}}}-1=\frac{\frac{P_{w}}{P_{n a}}}{\frac{E^{*} P_{w}}{E_{0} P_{n a}^{*}}}-1=\frac{P_{n a}^{*} E_{0}}{P_{n a} E^{*}}-1
$$

where $P^{*} w$ is the border price at the equilibrium exchange rate $E^{*}$ and adjusted as before so that $P^{*} w=P_{b p} E^{*}=P w E^{*} / E_{0}$; and $P^{*}{ }_{n a}$ is a non-agricultural sector price index, where the price index of the tradable part is evaluated at $E^{*}$ and in the absence of trade 
interventions $\left(t_{n a}\right)$ affecting non-agricultural tradables, so that $P_{n a}^{*}=\frac{\beta P_{n a T} E^{*}}{E_{0}\left[1+t_{n a}\right]}+[1-\beta] P_{n a T}$.

Total nominal protection is

$$
N P R_{T}=\frac{\frac{P_{d}}{P_{n a}}-\frac{P_{w}^{*}}{P_{n a}^{*}}}{\frac{P_{w}^{*}}{P_{n a}^{*}}}=\frac{\frac{P_{d}}{P_{n a}}}{\frac{P_{w}^{*}}{P_{n a}^{*}}}-1
$$

Because the denominator of equation (2.14) differs from that of equation (2.15) as well of (2.16), $N P R_{D}+N P R_{I} \neq N P R_{T}$. To make the three measures comparable, another direct protection rate is defined as

$$
n p r D=\frac{\frac{P_{d}}{P_{n a}}-\frac{P_{w}}{P_{n a}}}{\frac{P_{w}^{*}}{P_{n a}^{*}}}
$$

which measures the impact of direct policies $\left[\frac{P_{d}-P_{w}}{P_{n a}}\right]$ as a percentage of the relative price that would prevail in the absence of all interventions [ $\left.P_{w}^{*} / P_{n a}^{*}\right]$, the same denominator is used in equations (2.15) and (2.16). Then, $n p r D+N P R_{I}=N P R_{T}$.

\subsubsection{Exchange rate misalignment}

The key issue in the above equations is the deviation of the exchange rate $\left(E_{0}\right)$ from its equilibrium value $\left(E^{*}\right)$. The actual exchange rate is often called a short-term exchange rate, while the equilibrium RER is called the long-term exchange rate. A difference between these exchange rates is called 'misalignment'. RER misalignment is now a standard concept in international macroeconomics and policy. In theory, the RER misalignment negatively affects economic performance, though in practice the magnitude of the negative effects depends on the type of misalignment, e.g. overvaluation or undervaluation. Overvaluation (undervaluation) means that the actual value of the exchange rate $\left(E_{0}\right)$ is smaller (greater) than its equilibrium value $\left(E^{*}\right)$. RAZIN and COLLINS (1997: 1) call the RER misalignment as "a situation in which country's actual RER deviates from some notion of an implicit "ideal RER". An exchange rate is labelled 'undervalued' when it is more depreciated than this ideal (or equilibrium), and 'overvalued' when it is more appreciated than ideal. Such misalignments are widely believed to influence economic behaviour. In particular, overvaluation is expected to hinder economic growth, while undervaluation is sometimes thought to provide an environment conductive to growth. 
In general, RER misalignment can arise when there are changes in fundamentals that trigger a change in the equilibrium RER, but that are not reflected in changes in the actual RER and visa versa. A different type of misalignment takes place when macroeconomic policies become incompatible with maintaining internal and external equilibrium, and give rise to a sustained appreciation of the actual RER. From a theoretical standpoint, the concept of misalignment requires assuming the existence of institutional or other type of rigidities that prevent the RER from adjusting rapidly towards its medium- to long-run equilibrium level (EDWARDS and SAVASTANO, 1999).

Misalignment means both overvaluation and undervaluation. Both influence economic growth through different channels. The main effects of overvaluation are spelled in DORNBUSCH (1988b):

- $\quad$ Undermining external competitiveness by overpricing exports. This would result in deterioration in the external balance and a depletion of foreign exchange reserves. This, in turn, may ultimately lead to a sharp devaluation in the wake of an external balance of payment crisis with the associated adverse impact on domestic prices and production.

- $\quad$ Causing misallocation of resources by distorting the prices of domestic goods relative to each other and to international prices. This would adversely affect domestic investment, causing losses to domestic production through reduced efficiency.

- Adversely affecting domestic financial markets, by increasing uncertainty in financial markets and by encouraging speculation against the domestic currency. If the overvaluation is sustained, many industries and banks may fail due to speculation. In the latter case, the government may have to bear heavy costs to bail out the financial system.

The negative impact of the RER misalignment (especially overvaluation) on economic growth was proven empirically. For example, EDWARDS (1988) studied 12 developing countries for the period from 1965-1985 and found out that the RER misalignment significantly undermined the growth in these countries. DOMAC and SHABSIGH (1999) found the significantly negative relationship between the RER misalignment and economic growth in Egypt, Jordan, Morocco and Tunisia during 19701995.

While the negative effects of the RER overvaluation are generally understood and accepted, the RER undervaluation is more controversial. RAZIN and COLLINS (1997) studied the relationship between RER misalignment and economic growth in 93 developed and developing countries over the period 1975 to 1992 and found that moderate to high (but not very high) undervaluations appear to be associated with more rapid economic growth. The undervaluation ranged from 1.2\% in the 'low' group to $10 \%$ in the 'very high' group.

Actually, low undervaluation may promote growth through increased competitiveness of domestic economy in the international markets and improved macroeconomic variables such as foreign reserves and interest rate. This is possible in the short run. From the other side, 'very high' undervaluation or 'low' undervaluation during long periods distorts the short-run profitability of foreign trade with respect to longer 
term opportunities. Therefore, it provides no guidance for capacity restructuring, encourages distress exports (i.e. unprofitable in equilibrium) especially in association with restrictive monetary policy, and disrupts patterns of production and trade which would be viable at a sustainable equilibrium rate. But the most damaging effect in the short run is probably its generation of inflationary pressures, under the guise of high profitability of exports and lack of competitiveness of imports (NUTI, 1996).

The balanced RER management, therefore, is distinctive issue to sustain economic growth. How the interest rate is important for economy in general and agriculture in particular, will be explored in the next sections. 


\subsection{Interest rates and agriculture}

Similarly to the previous section on influence of the RER on agricultural incentives, an analysis of impact of the interest rate on agriculture begins with a literature overview for developed countries. Again, literature on the U.S. agriculture is abundantly available.

\subsubsection{Literature overview}

\subsubsection{Interest rate and agriculture in developed countries}

In recent decades, agriculture has become one of the most capital-intensive sectors of the U.S. economy. According to THOMPSON (1988), the capital-output ratio in agriculture reached three times figure of the U.S. economy as a whole by decades ago. Moreover, agriculture has become increasingly dependent on debt financing. During the 1970s, the total debt burden of American farmers increased from $\$ 65$ bln to more than $\$ 200$ bln. "As a result, the interest rate has actually become the only important price affecting farmers' bottom line. In 1984, the U.S. farmers have paid \$21 bln in interest on borrowed money - six times the $\$ 3.4$ bln spent in 1970 . In the U.S. agriculture a $1 \%$ change in the real rate of interests leads to about $\$ 2$ bln change in farm interest expenses" (KNUTSON et al., 1995: 198). The impact on investment decisions, price of land, storage of commodities, or value of dollar is considerably more obscure. According to GERTEL (1990), for example, since the 1970s, the real interest rate along with returns have become a major determinant of farmland prices in the United States.

In the last 50 years the interest rate played an important role for development of the U.S. agriculture. CRAMER et al. (1997) summarise the general impact of short-run changes in monetary and fiscal policies on the U.S. agriculture during this period as follows:

- $\quad$ Expansionary monetary policies during the 1970s led to increasingly high inflation rates, low real interest rates, and a depreciated dollar at the international money markets, which helped to spur the foreign demand for the U.S. agricultural commodities. High inflation and increased prices of farm inputs increased the U.S. farm production costs, but export demand expansion kept farm prices and net income rising. Also, farm debt grew over this period of time, since many farmers borrowed not only against their rising land values to add to their land holdings, but also from other funds to increase their production.

- At the end of 1979 , monetary policy abruptly became a contractionary with the objective of lowering the rate of inflation. As a result, the interest rates reached record levels in the 1980-82 period. Simultaneously, foreigners began to view the United States as a more favourable place to invest, causing the value of the dollar to increase by $50 \%$ between 1980 and early 1985. Foreign demand for U.S. agricultural products fell both because of dollar's appreciation and because many food-importing countries suffered economic reverses that limited their purchasing power. The U.S. agriculture was severely hit by the combination of lower product demand and higher production costs - especially when much larger interest payments were required to service a sharply increased farm debt. 
- The contractionary monetary policy was successful in reducing the rate of inflation from more than $10 \%$ in the early 1980 s to about $3 \%$ in $1984-85$. Nominal interest rates began to decline in 1984, partially because of lowered inflation expectations. Current interest rates declined to the lowest level in 25 years. The exchange value of the dollar peaked in early 1985, and by 1995 had declined to its 1980 level. These changes, along with emphasis on trade liberalisation, were favourable to the U.S. agriculture. Foreign demand for the U.S. agricultural products has improved with the economic recovery in many other countries.

This short historical overview of CRAMER, JENSEN and SOUTHGATE proves the great importance of interest rate and other macroeconomic variables for the adjustment processes of the U.S. agriculture. That the interest rate conditions the development of the U.S. agriculture is also enlightened by KNUTSON et al. (1995). The authors write that as during the period of 1973 through 1979, real interest rates were negative; the clear signal for the farmers was to borrow, to invest, and to expand. Encouraged by high farm prices and incomes, farmers began to borrow. Farm debt rose threefold from $\$ 63$ bln in 1972 to $\$ 181$ bln in 1981. In addition, farmers bought farm machinery and land. The average value of farmland increased from $\$ 219$ per acre in 1972 to $\$ 819$ per acre in 1981 . The change in macroeconomic policy in 1981 shifted real interest rates to the opposite extreme, which resulted in a sharp and the highest rise of the real interest rate to up nearly $12 \%$. Investment in land and farm machinery tumbled with a corresponding decline in asset values. The value of farmland declined to as low as $\$ 547$ per acre in 1987. The subsequent relative stabilisation of real interest rates in the late 1980s and early 1990s, combined with relatively stable farm policy led to some recovery of average land prices up to $\$ 685$ in 1992.

An importance of effects of interest rate on agricultural exports through the transmission mechanism to RER was already mentioned above. NILES and ORDEN (1998) describe this mechanism, stating that the U.S. interest rates relative to the rest of the world ultimately have a detrimental effect on the U.S. agricultural exports. Foreign investors become eager to invest to the U.S. financial markets; to do this they must buy dollars with their foreign currency, generating a high demand for the U.S. dollars. A high demand for US dollars, induced by high domestic interest rates or other factors, thus manifests itself in an appreciation of the dollar, which makes the U.S. exports less competitive in the world markets.

Australian farmers are similarly sensitive to the interest rate changes as in the United States. WARREN TRUSS, the Minister for Agriculture, Fisheries and Forestry of Australia, called the half percent cut of the market interest rate in 2001 as "exactly the sort of encouragement our farmers need to develop new and innovative products or to improve their farming techniques and practices". A farmer with average debt of $\$ 170000$ will typically save another $\$ 850$ in annual loan servicing costs. Moreover, TRUSS adds that "the rate cut will further strengthen business confidence on the farm and boost the contribution of the agriculture to the wider Australian economy" (see TRUSS, 2001). O'MARA et al. (1987: 446) states that "while it is difficult to assess the precise magnitude of the change in interest rates which might accompany such a movement in the real exchange rate, it might be noted that interest payments on farm debt would fall by around $\$ 80$ mln per year for each 1 percentage point decline in the interest rate". 
The impact of the interest rate on the agricultural variables such as prices and exports is often estimated by vector autoregressive (VAR) models. In this context, let us mention two studies on the European agriculture. SCHMITZ and HofFMANN (1996) estimated the impact of macroeconomic variables on agricultural prices and agri-food exports in Germany over 1976-1994. They found no large impact of the interest rates on the farm prices, but rather long-term increased cost effect on farm profits. On the other hand, the impact of the interest rate on the agricultural exports is significant as the higher interest rates induce the appreciation of the RER through an encouragement of capital inflows. KAABIA and GIL (2000) revealed the significantly negative effect of the increase of interest rate on agricultural exports in Spain during 1978-95. Higher interest rates led to the RER appreciation pushing agricultural prices down, and increasing production costs. Moreover, real prices for agricultural inputs remained significantly above their original level over longer time than in the case of real output prices.

In contrast to the literature on developed countries, research in developing countries concentrates on the functioning of rural financial markets and poverty alleviation, rather than on the influence of interest rate on farm production costs and exports (see, for example, QUERESHI et al., 1996; ZELLER et al., 1996; ZELLER and SHARMA, 1998). Agriculture in these countries is mainly labour-intensive and the farms are very small-scaled. Although the examples from the developing countries could be useful for this literature overview, especially for issues of rural financial markets, their consideration is not critically important here. Hence, we directly turn to the literature overview for the CEE transition economies.

\subsubsection{Interest rate and agriculture in transition economies}

Literature on the CEE transition economies pays a special attention to the role of financial markets in accelerating the transition from a centrally planned to market economy, while empirical estimations of the impact of the interest rate on agriculture are rare. Transition from a plan to a market economy induces significant changes in capital markets of these countries. SWINNEN (2002) stresses out that in early period of transition, credit markets have worked notoriously imperfectly with disruption due to privatisation and overall restructuring. That caused major problems for farms, not only because of a lack of funds for long-term investment, but also because of a diminished access to working capital. These resulted in reductions in output; and the success of the recovery in some countries was at least partially reached due to improvements in the general economic climate which improved the working capital situation for the farms.

That financial markets are important for farm performance is also supported by KOESTER (2001). He states that financial markets are important for the functioning of today's markets. At the same time they link today's markets with tomorrow's markets. "Without functioning financial markets, savings will hardly be mobilised and funds will not be directed to their most profitable location. Thus, the economy is distorted, more in favour of consumption goods at the expense of capital goods and more in favour of short term investment than of medium and long term. These economies grow less rapidly than those with functioning financial markets" (KOESTER, 2001: 2).

To attract more capital to the agricultural sector, many governments of the CEE countries subsidise interest rates. In this manner, the policy makers want to compensate the underdevelopment of the financial markets. The literature on this issue conclusively 
suggests that such a policy is predestined to fail, as credit subsidies address the symptoms of the problem, not the causes (KOESTER, 2001; STRIEWE et al., 2001a; PETRICK, 2002).

Among many preconditions, macroeconomic stability is in great importance for functioning of the financial markets. It ensures not only low interest rate for farmers, but it also makes agricultural sector less risky. HAYASHI (2001: 17) points out that "the macroeconomic instability affects the profitability of the agricultural sector because of the uncertainties and risk created for producers and the difficulty for lenders to assess the risk." A sound macroeconomic policy, therefore, is not less desirable than the level of interest rate per se.

While the macroeconomic stability is an important determinant of the creation of viable financial markets, there is a broad consensus that profitable agriculture is not less important precondition as well. To attract finance and credit, agriculture needs to generate sufficient profits. The following issues of agricultural profitability with regard to rural finance are often discussed: bad prospects with respect to finance for a nonrestructured agricultural sector, reform of farm business management, debt resolution of large farms, transparent agricultural policy, and efficiency of the whole food chain (see VON PISCHKE, 1999; CSAKI and LERMAN, 2001; KOESTER, 2001; VON PISCHKE, 2001).

Concerning Ukraine, SEDIK (2001) and STRIEWE et al. (2001a) considered the farm debt problem as a major handicap to attract external finance. At the same time, it is stressed out in both papers that the underlying problem of Ukrainian farms appears to be not debt but lack of profits. "Public policies that diminish incentives for good financial performance, continued production of livestock products and considerably more labour and land employed in Ukrainian farms than in comparable market oriented farms" are among main reasons for these low profits (SEDIK, 2001: 119). How low farm profitability in Ukraine affects macroeconomics and probably the rate of interest itself will be considered in section 3.3 of this dissertation. Now it will be explained though which channels interest rate can influence the economy in general on the one hand and agriculture in particular on the other.

\subsubsection{Interest and exchange rates in an open economy framework}

Interest rates affect production, consumption and investment decisions. Usually, higher interest rate results in lower production, lower investments and higher savings. The linkages between interest rates and output are often studied by using the IS-LM model. This model considers the relationship between money and good markets and demonstrates how changes in fiscal and monetary policies can affect output via interest rate. In comparison to the Dependent Economy Model presented above, the IS-LM model considers the interest rate as a distinct factor for the real domestic demand. Although it makes theoretical framework more complicated, it permits distinguishing the short- and long-term economic relationships.

The $I S$ curve in the model describes the combinations of income and interest rates at which the market of goods is in equilibrium (such that planned spending equals income), while the $L M$ curve describes the combinations of income and interest rates at which the market of money is in equilibrium (such that money demand equals money 
supply) (see DORNBUSCH et al., 1998: chapter 10). This model finds values of a GDP $\left(Y_{0}\right)$ and an interest rate $\left(i_{0}\right)$ which simultaneously clear goods (presented by $I S$ curve) and money ( $L M$ curve) markets (see figure 8).

\section{Figure 8: Goods and money market equilibrium in IS-LM model}

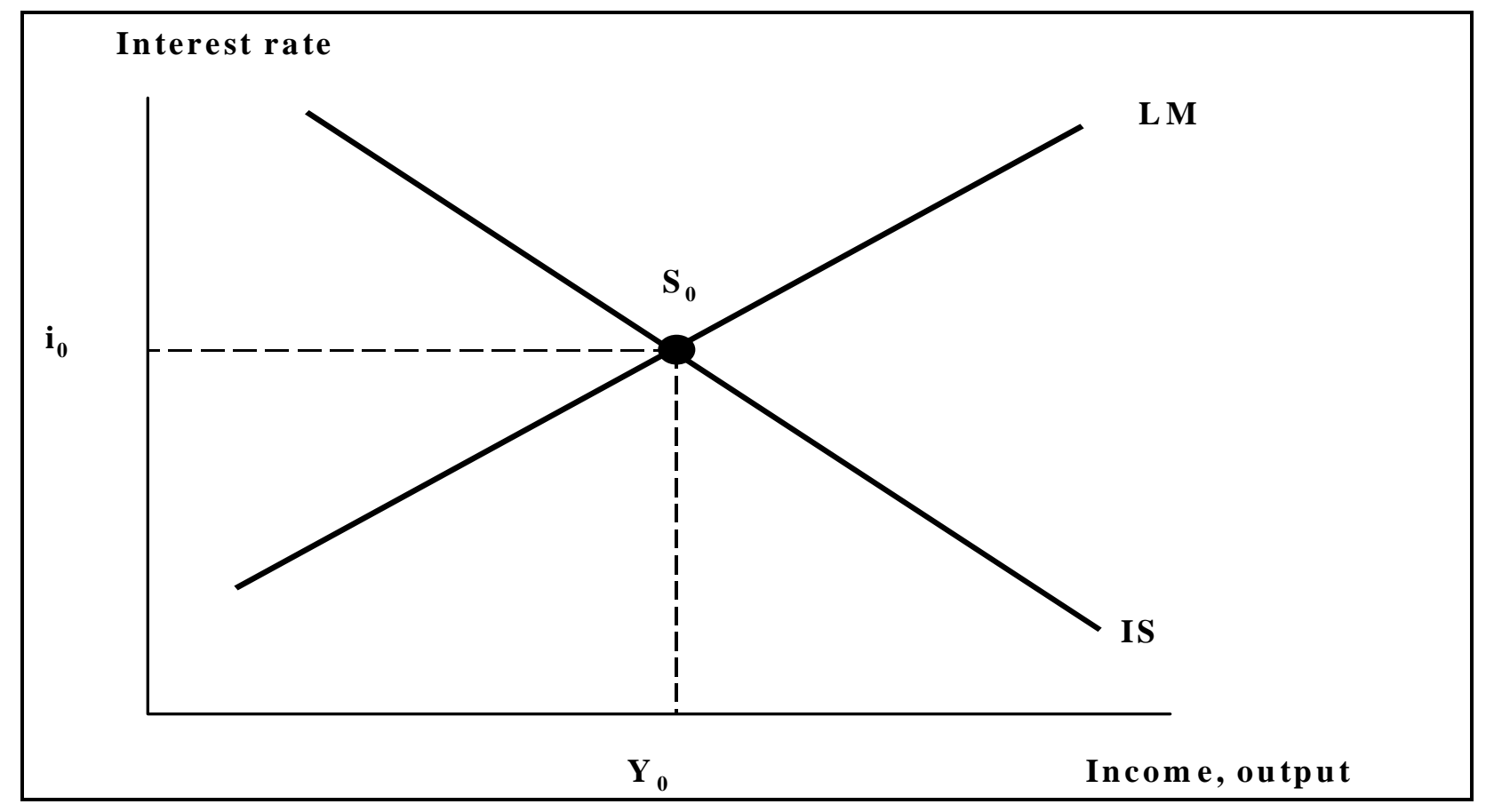

Source: DORNBUSCH et al. (1998: 230).

In an open economy, changes in the interest rate have macroeconomic consequences well beyond their direct effects on investment and production decisions. So far, the external sector was excluded from our discussion. An extension of the standard IS-LM model to the open economy under perfect capital mobility has a special name, the MUNDELL-FLEMING MODEL (see KENEN, 1995 for broader insights). This model allows studying the impact of fiscal and monetary policy on output under constraints of capital inflows. In this context the relationships between real exchange and interest rates are in a paramount importance. It is assumed that the world rate of interest $\left(i_{w}\right)$ is exogenously given, and any deviation of the domestic interest rate $(i)$ from the world level ultimately encourages capital flows until interest rates are equalised, i.e. $i=i_{w}$. The balance of payments can be specified in the way to produce these relationships. With the capital inflows, the balance of payments surplus $(B P)$ is equal to the trade surplus $(N X)$ plus the capital account surplus $(C F)$ (DORNBUSCH et al., 1998: 517):

$$
B P=N X(Y, e)+C F\left(i-i_{f}\right)
$$

Equation (2.18) shows the trade balance as a function of domestic income $(Y)$ and RER (e) and the capital account as depending on interest rate differentials. An increase of income worsens the trade balance, and an increase in the interest rate above the world level pulls in capital from abroad and thus improves capital account. It follows that when domestic income increases, even the tiniest increase in interest rates is enough to maintain an overall balance of payments equilibrium. The trade deficit would be financed by capital inflows. 
The potential for capital inflows to finance a current account deficit is extremely important. Countries frequently face policy dilemmas, in which a policy designed to deal with one problem worsens another problem. Similarly to the above DEM, there is sometimes a conflict between the goals of external and internal balance (see figure 9). Recall that external balance exists when the balance of payments is close to balance, while internal balance exists when output is at full-employment level.

\section{Figure 9: Internal and external balance in the Mundell-Fleming model}

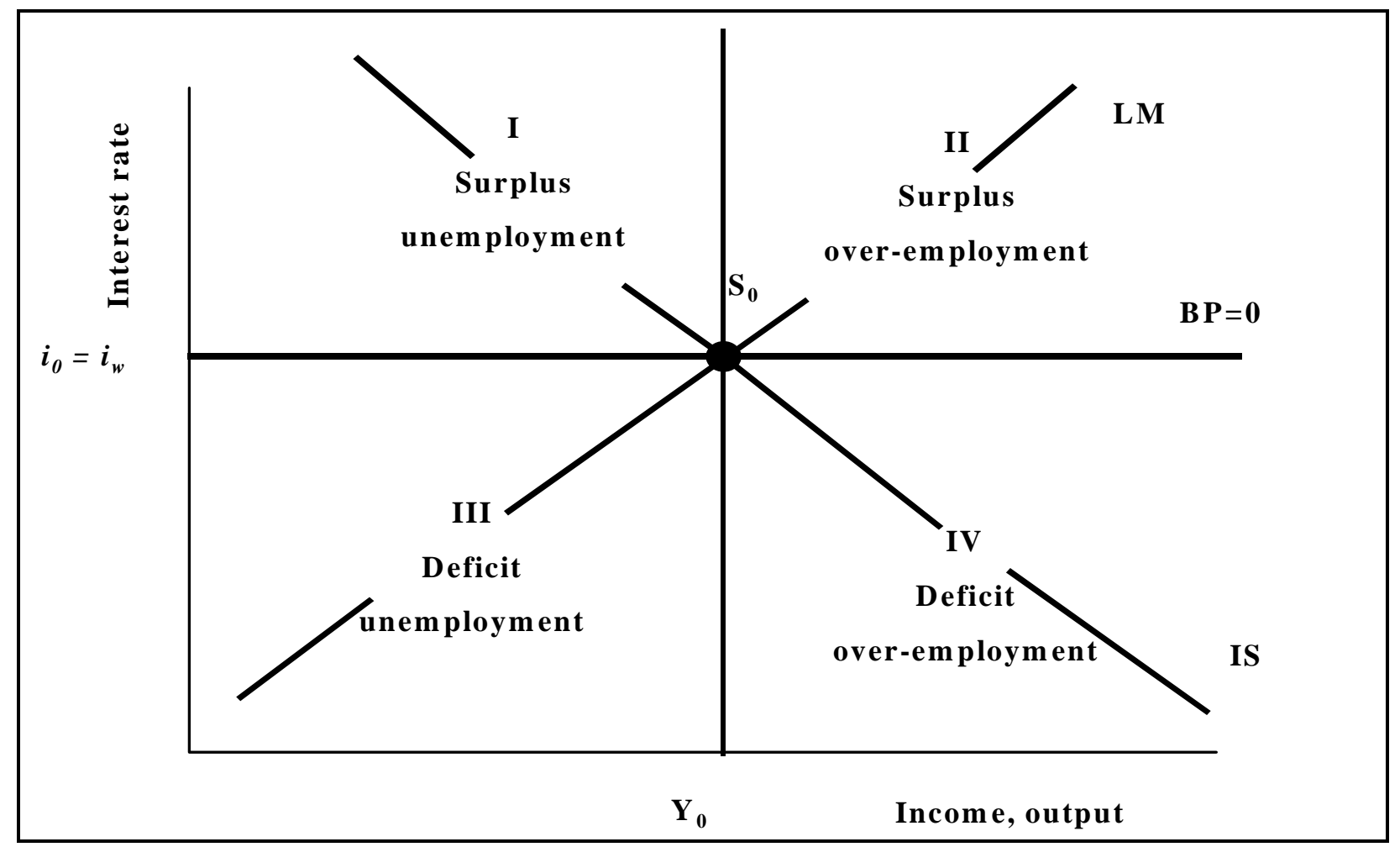

Source: $\quad$ Adapted from DORNBUSCH et al. (1998: 282-285).

In figure 9 the schedule $B P$ equals 0 , along which we have balance of payments equilibrium. The key assumption of the model - perfect capital mobility - forces the $B P=0$ line to be horizontal. Points above the $B P=0$ schedule corresponds to a $B P$ surplus, and points below to a deficit. At the same time, points to the link from the equilibrium employment level $Y_{0}$ correspond to unemployment, while points to the right - overemployment. Similarly to SWAN diagram of the DEM, the policy makers face four "zones of economic unhappiness". At any point that deviates from the overall equilibrium $\left(S_{0}\right)$, the economy finds itself in unbalanced position. It can return to the equilibrium position through the automatic adjustment process, but it may take a very long time and require a very long recession. Policy makers have the opportunity to use the instruments of monetary and fiscal policies to accelerate and smooth the process of equilibrium restoration.

In an open economy, the choice of policy instruments hinges on the nominalexchange-rate-regime maintained in the country, because various exchange rate systems constraint the efficiency of use of either monetary or fiscal policies. Let us assume that domestic prices remain constant, which is close to the short-term consideration (later this assumption will be relaxed to consider the long-term effects). 
First, in the situation of a fixed exchange-rate-regime, the central bank stands ready to buy and sell its currency at a pre-announced price in terms of foreign currency. Suppose a country wishes to raise interest rates. It tightens its monetary policy (i.e. monetary contraction), and interest rate increases (see figure 10). As the $L M$ schedule shifts up and to the left, and the economy moves to the point $S_{1}{ }^{6}$ Immediately, portfolio holders world-wide shift their wealth to take advantage of the new higher rate. As a result of capital inflows, the balance of payments shows a surplus; foreigners try to buy domestic assets, tending to cause the exchange rate to appreciate and forcing the central bank to intervene to hold the exchange rate at fixed pre-announced level. It buys the foreign money, in exchange for domestic money. This intervention causes the home money stock to increase. As a result, the initial monetary contraction is reversed. The process comes to the end when domestic interest rate has been pushed back down to the initial level. The conclusion is this: "Under fixed exchange rate and perfect capital mobility, a country cannot pursue an independent monetary policy. Interest rates cannot move out of line with those prevailing in the world market. Any attempt at independent monetary policy leads to capital flows and a need to intervene until interest rates are back in line with those in the world market" (DORNBUSCH et al., 1998: 283).

While monetary policy is essentially infeasible, fiscal policy under fixed exchange rate system with perfect capital mobility is, by contrast, extremely effective. With the money supply initially unchanged, a fiscal expansion moves the $I S$ curve up and to the right (point $S_{1}$ ), tending to increase both the interest rate and the level of output (see figure 11). ${ }^{7}$ The higher interest rate would cause the capital inflows and the exchange rate to appreciate. To maintain the exchange rate, the central bank has to expand the money supply, thus increasing income further. Equilibrium is restored when the money supply has increased enough to drive the interest rate back to its original level $\left(i=i_{w}\right)$. The economy moves to the new equilibrium $S_{2}$ at which more output $\left(Y_{2}\right)$ is produced at the stable interest rate.

\footnotetext{
${ }^{6}$ A length of the shift depends on size of the monetary policy multiplier, which shows how much an increase in the real money supply increases the equilibrium level of income, keeping fiscal policy unchanged.

${ }^{7}$ Similarly to the monetary policy multiplier, the shift of the IS curve depends on fiscal policy multiplier which shows how much an increase in government spending changes the equilibrium level of income, holding the real money supply constant.
} 
Figure 10: Effects of monetary policy Figure 11: Effects of monetary policy under under fixed exchange rate fixed exchange rate
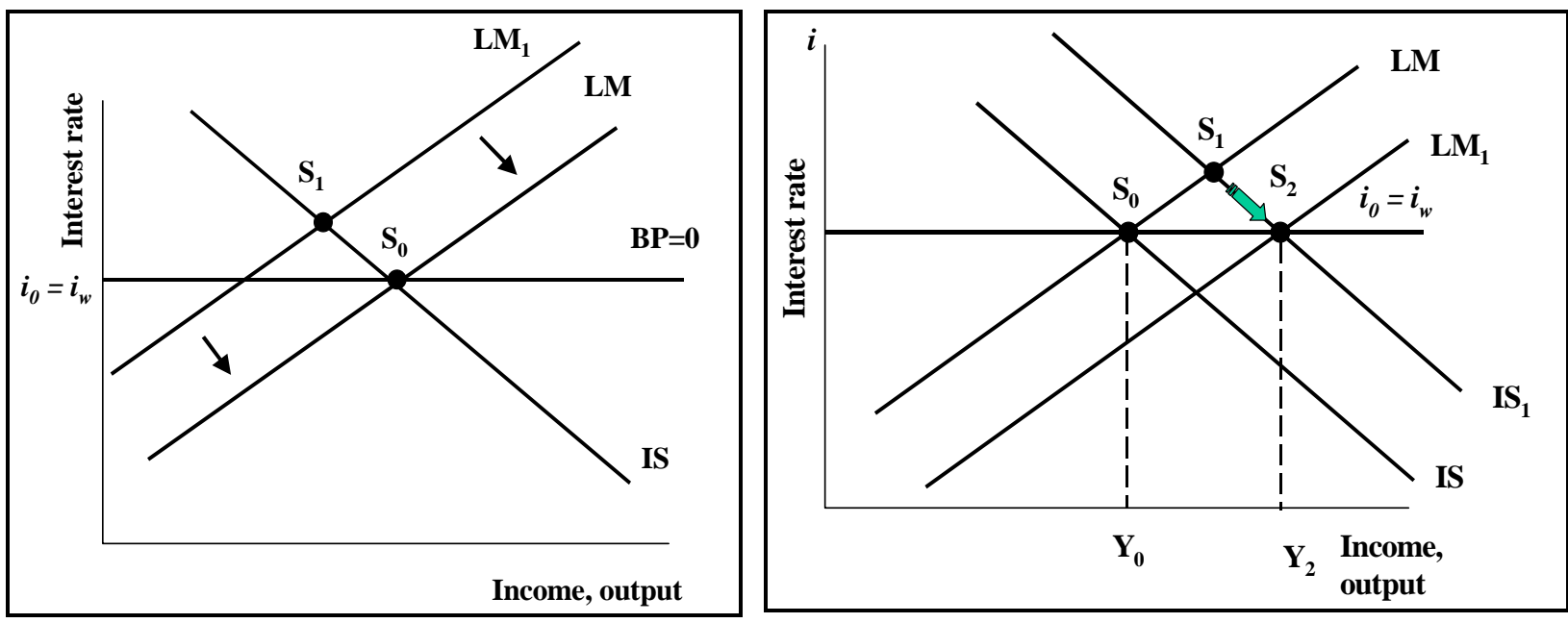

Source: DoRNBUSCH et al. (1998: 285).

Source: Adapted from DORNBUSCH et al. (1998).

In a world of flexible exchange rate regime, the central bank does not intervene in the foreign exchange market. The exchange rate must adjust to clear the market so that the demand for and supply of foreign exchange are in balance. Any current account deficit (surplus) is financed by capital inflows (outflows) since adjustments in the exchange rate ensure that the sum of the current and capital accounts is zero.

A second implication of the flexible exchange rates is that the central bank can set money supply at will. Since the central bank has no obligations to intervene, there is no longer the link between the balance of payments and the money supply. Hence, in this case the monetary policy is extremely effective. The adjustments in the economy after the monetary expansion are presented in figure 12. Starting from the initial position $\left(S_{0}\right)$, an increase of the stock of money will increase the real money supply. At $S_{0}$ there will be an excess supply of real balances. To restore the equilibrium, the interest rate would have to be lower, or income would have to be larger. Accordingly, the $L M$ schedule moves down and to the right to $L M_{1}$. At $S_{1}$ the goods and money markets are in equilibrium, but interest rates have fallen below the world market level. Capital outflows therefore put pressure on foreign exchange, inducing the exchange rate depreciation. Import prices grow, while domestic goods become more competitive. The depreciation shifts the $I S$ schedule up and to the right. The depreciation continues until two interest rates are equal and the new equilibrium shifts to the point $S_{2}$. Under flexible exchange rates and perfect capital mobility the monetary expansion, therefore, is an effective policy tool to expand the equilibrium output.

In contrast, the fiscal policy does not have power under flexible exchange rate (see figure 13). A fiscal expansion, for example, leads to an expansion in the demand for domestic goods. The $I S$ curve shifts up and to the right to $I S_{l}$. At point $S_{l}$, high interest rate would encourage capital inflows and induced RER appreciation would cause a fall in exports and increased imports. An exchange rate appreciation will bring the economy back to the initial equilibrium $S_{0}$. This process is called complete crowding out "because the exchange appreciation reduces net exports" (DORNBUSCH et al., 1998: 289). 
Figure 12: Effects of an increase in Figure 13: Effects of fiscal expansion money stock under flexible exchange rate

\section{under flexible exchange rate}

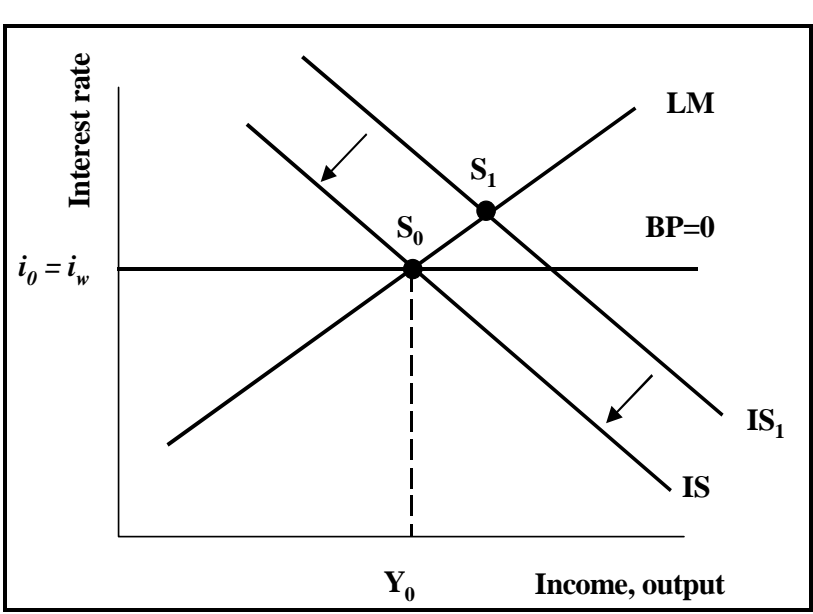

Source: DoRNBUSCH et al. (1998: 290).

Source: DORNBUSCH et al. (1998: 288).

Finally let us turn to the situation when domestic prices are allowed to fluctuate. In above discussion, the price level was constant that did not allow distinguishing among nominal and real exchange rates. Relaxation of fixed price assumption helps to show the adjustment processes in an open economy both in short and long run. Again, the interdependencies between exchange and interest rates will hinge on the exchange rate system in place.

Let us start with the situation under fixed exchange rate regime. First, recall the definition of the real exchange rate: $e=E P_{f} / P$, where $E$ is the nominal exchange rate, $P_{f}$ is the index of foreign prices and $P$ is the index of domestic prices. Consider the economy from another perspective (see figure 14). The total supply is presented by the $S$ curve, while the total demand equals to the sum of domestic demand $\left(D D_{0}\right)$ plus net exports $\left(N E_{0}\right)$. At the point $S_{0}$ the economy is in equilibrium. How does this economy adjust to the various shocks?

Let us consider the case with decrease of foreign demand for domestic goods. The net export moves down and to the right to $S_{l}$. At $S_{1}$, the country has a trade deficit and unemployment. The central bank can finance this deficit through either its foreign reserves or it can borrow money abroad. But maintaining and financing the trade deficit indefinitely, or for very long periods of time is impossible. The economy has to find some way of adjusting the deficit. Similarly to the DEM framework, a combination of expenditure switching which shifts demand between domestic and foreign goods, and expenditure reducing policies, can cope with the restoration of the equilibrium. The major policy instrument for dealing with payment deficits and consequent unemployment is devaluation, which usually has to be combined with restrictive monetary and/or fiscal policy. Devaluation is primarily an expenditure switching policy since it increases relative import prices and makes the domestic goods cheaper and thus, more competitive on world markets. The process of devaluation is demonstrated by shifting to the new equilibrium $S_{2}$ in figure 14 . 
Figure 14: Effects of loss of export revenue and necessity of real depreciation

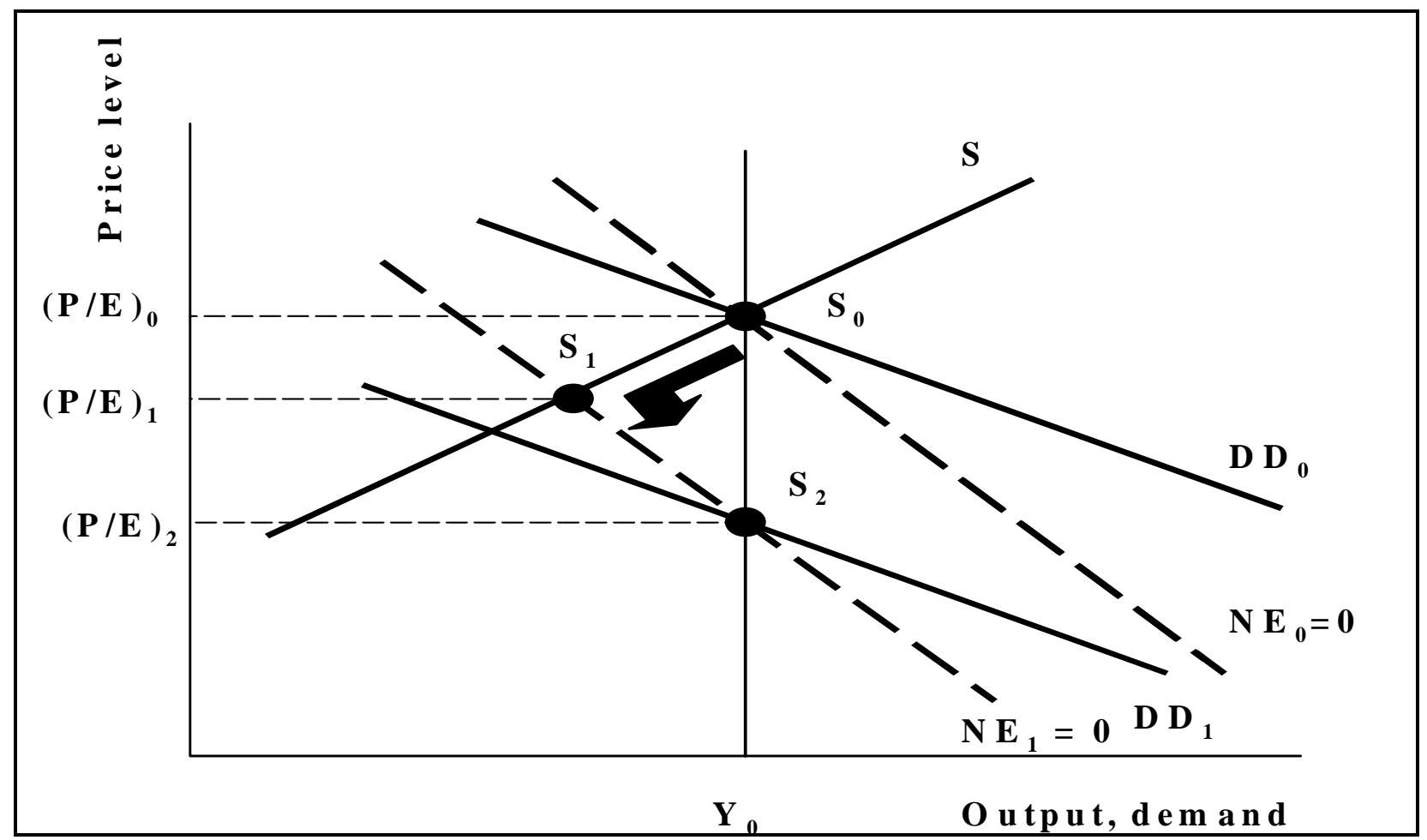

Source: $\quad$ Adapted from DoRnBUSCH et al. (1998: 497).

Along the ordinate axis (price level) is not nominal, but rather real exchange rates are shown. The reason is that devaluation can be inflationary and lead to an increase in domestic prices. If the nominal exchange rate $(E)$ and domestic prices $(P)$ grow at the same rate, devaluation of the exchange rate is ineffective, because it did not change relative price ratio $(\Delta P / \Delta E=1)$. Hence, exchange rate devaluation can be sustainable only if the policy makers keep domestic prices in line with foreign prices. For that purpose, long-term structural policies are in a paramount importance.

The analysis of a monetary expansion under flexible exchange rate regime with given domestic prices presented above shows that it is an effective way to increase income by depreciating the exchange rate. How is the model modified once the price adjustment is taken into account? The situation in the long run is presented in figure 15. As in figure 12 the analysis starts with point $S_{0}$ with full employment, a payments balance, monetary equilibrium, and equilibrium in the domestic goods market. Now a monetary expansion takes place and shifts the $L M$ schedule to $L M_{l}$. As in $S_{l}$ the interest rate is lower than the world market rate, the exchange rate immediately depreciates, rising home competitiveness, and thus shifting the $I S$ schedule to $I S_{l}$. The economy moves to $S_{2}$, output has risen, the exchange rate has depreciated, and the economy has thereby gained in external competitiveness. But with flexible domestic prices, this is not the end of the story (as is the case in figure 12).

At $S_{2}$ the economy is above the full employment level. Prices are therefore rising, and that implies that real balances are falling. As the real money stock (money supply divided by prices) declines, the $L M$ schedule shifts to the left. Interest rate tends to raise, capital to flow in, and resulting appreciation now leads to a worsening competitiveness that also shifts the $I S$ schedule back towards the initial equilibrium. The process 
continues until the economy reaches the point $S_{0}$. What does it mean for the economic adjustment? It means that in the long run money is entirely neutral.

\section{Figure 15: Short- and long-term effects of monetary expansion}

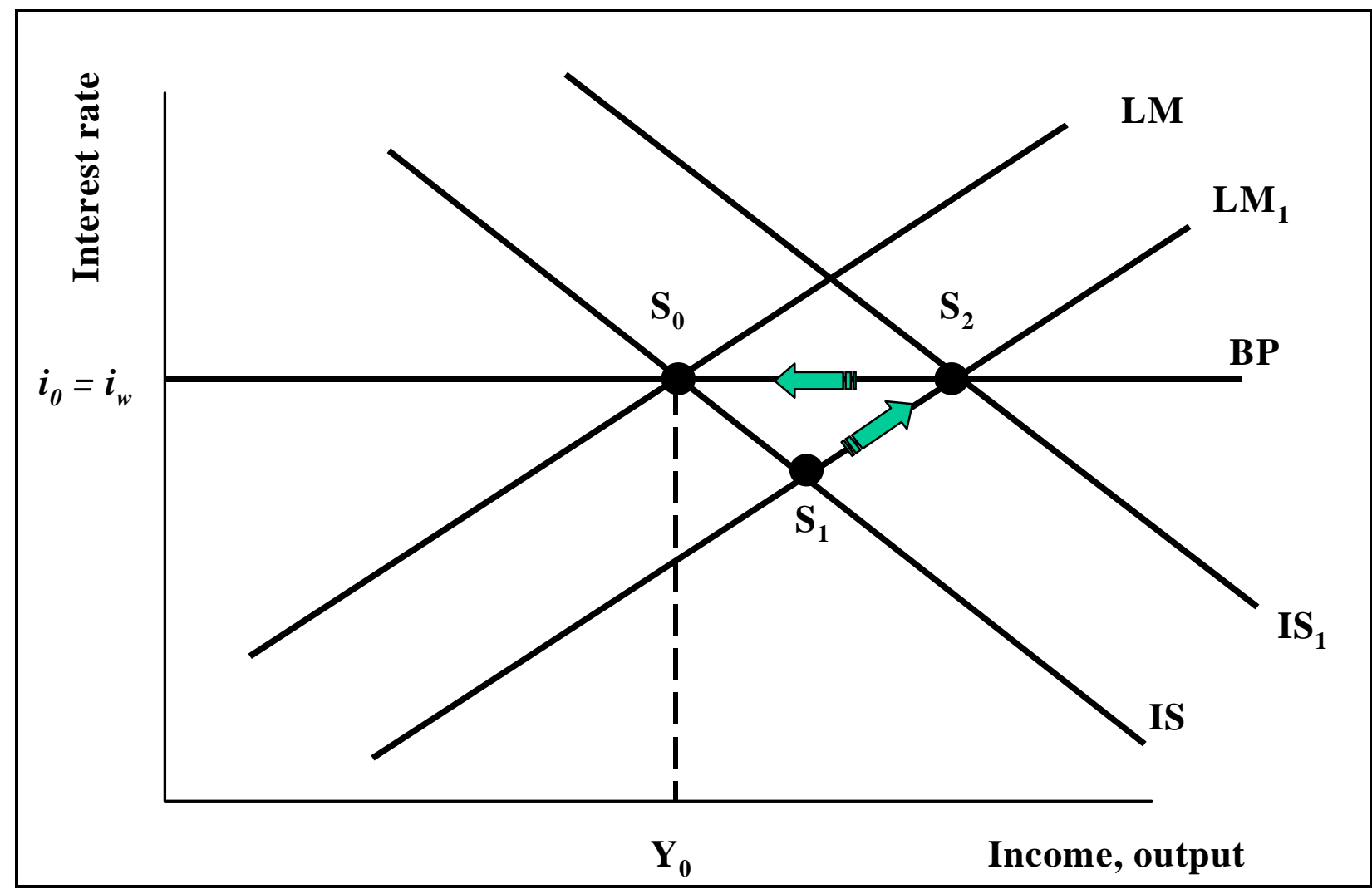

Source: $\quad$ Adapted from DoRNBUSCH et al. (1998: 512).

The above-conducted theoretical analysis of complex interlinkages in an open economy urges policy makers to carefully design the intervention measures. Reality is additionally burdened by market imperfections and rigidities which are difficult to model. For instance, cases of perfect capital mobility are rare in the transition economies: the interest rate differentials should be additionally adjusted to country specific risks. From the above analysis it is also evident that the macroeconomics of the open economy is important for agriculture as well. An important article in this respect is those of SNAPE (1989), who explores the relationships between exchange and interest rates on the one hand, and their impact on agricultural development in the Mundell-Flemming framework on the other.

The important outcomes of the above analysis for agriculture can be summarised as the follows:

- Any change of the real interest rates leads to the shifts of the RER,

- An increase (decrease) of the real interest rate usually induces the RER appreciation (depreciation) through encouragement of the capital inflows (outflows), and,

- The increases of the interest rate negatively affects farmers not only by increasing production costs and constraining access to the external financing, but also through the RER appreciation. 
The usual outcomes of fiscal and monetary policies on some agricultural and macroeconomic variables as well as of interactions of the real exchange and interest rates are presented in the table 3 .

Table 3: Influence of monetary and fiscal policies on some agricultural and macroeconomic variables

\begin{tabular}{lcccc}
\hline & $\begin{array}{c}\text { Monetary policy } \\
\text { (Changes in money supply) }\end{array}$ & $\begin{array}{c}\text { Fiscal policy } \\
\text { (Changes in government spending) }\end{array}$ \\
\hline \hline Domestic farm prices & Increase & Decrease & Increase & Decrease \\
Export farm prices & Increase & Decrease & Decrease & Increase \\
Farm input prices & Increase & Decrease & Increase & Decrease \\
Inflation & Increase & Decrease & Increase & Decrease \\
Real interest rate & Decrease & Increase & Increase & Decrease \\
Real exchange rate & Depreciate & Appreciate & Appreciate & Depreciate \\
\hline Source: $\quad$ Own presentation based & on CRAMER et al. & $(1997:$ 238) and PENSON et al. &
\end{tabular}

\subsubsection{Interest rates, farm production costs, and farm debts}

In addition to the impact on various macroeconomic variables, the interest rate has direct significant effects on agricultural sector. First of all, its effects are important because agriculture uses a high level of physical capital per unit of output and because the farm sector is an active user of external financing. In this context the interest rates greatly affect the choice of farm technologies. Secondly, for commodities in which large stocks are held, the interest rate is an extremely important determinant of the profitability. And finally, interest rates determine the rental and thus, purchasing prices of the agricultural land.

Along with production factors, interest rates influence farm competitiveness through the choice between different technologies (for example, capital versus labour intensive) in the production processes. Capital has an opportunity cost and can be rented like labour or land. Compensation for its use is accomplished through the interest rates. In this case real interest rates are used to estimate the opportunity costs of using capital in the production process. In general, farmers are concerned with their terms of trade, i.e. with ratio of 'wage' of capital (interest rates) to price of produced output. Therefore, real instead of nominal rates of interest are used to estimate the impact of the interest rates on production costs.

Any production technology consists of variable and fixed costs, where capital often plays the leading role. ${ }^{8}$ To produce wheat or sugar beet, the farmer uses seeds, fertilisers, chemicals, fuel, etc. To purchase these inputs, the farmer can use his own capital or borrow working capital from commercial banks, input suppliers (in the form of

\footnotetext{
${ }^{8}$ The division between variable and fixed costs is relevant only for the short-term period. For the long-term production decisions all costs are variable (see BENECKE (2000)).
} 
trade credit) or the state. In the former case interest equals to the alternative use of own capital (at the shadow interest rate), while in the latter - the interest paid for short-term credits. As a rule, a short-term credit is given for around six months, i.e. from seeding to harvest campaign. The interest accrued, therefore, often equals to a half of annual real interest rates.

Moreover, the agricultural machinery and equipment, as well as other movable and fixed assets should be used to maintain competitiveness. Since in many transition economies, including Ukraine, the machinery park is very old and almost completely depleted, large long-term capital investments are needed to sustain farm competitiveness. If the farmer attracts the long-term external financing, the real interest rate on capital used raises farm production costs.

Similarly, the interest rates determine the technologies of livestock production. Currently in Ukraine the livestock production is labour intensive. But to increase profitability and sustain over a long run, the investments into better feed, breeding, herd inventory, milking equipment and fixed assets are inevitable. Such investments are linked with the interest rates (see VENEMA, 2002). Table 4 presents the schema of 'gross margin' calculation and highlights the role of interest rates in it and the following equation summarises the influence of interest rate on production costs:

$$
\sum_{t=1}^{n} P C_{j t}=\left[\sum_{t=1}^{n} V C_{j t}+\frac{12}{m} i c_{t}\right]+\left[\sum_{t=1}^{n} F C_{j t}+i c_{t}\right]
$$

where $P C_{j t}$ are production costs of $\mathrm{j}$ in period $1 \ldots \mathrm{n}, V C_{j t}$ are variable costs (without interest rate costs), $F C_{j t}$ are labour costs and depreciation (without interest rate costs), $i c_{t}$ is interest rate costs, and $m$ is a number of months of accrued working capital. ${ }^{9}$

Table 4: Schematic presentation of gross margin calculations

\begin{tabular}{cl}
\hline+ & Sales revenue (yield x price) \\
+ & Revenue from sale of joint product (e.g. straw) \\
+ & Per hectare subsidies \\
\hline$=$ & Total revenue \\
\hline \hline- & Seed costs \\
- & Fertiliser costs \\
- & Pesticide and herbicide costs \\
- & Machinery costs (e.g. seeding, harvesting) \\
- & Other variable costs \\
\hline$=$ & Grerest rate on short-term credits \\
\hline \hline- & Fixed machinerv costs (depreciation + interest rate on long-term credits) \\
\hline = & Labour costs \\
\hline Source: & Adapted from BENECKE and VON CRAMON-TAUBADEL (2001: 216)
\end{tabular}

${ }^{9}$ In this equation the universal real interest rate is used for simplicity, while in the reality for each production factor different rates of interest can be applied. It especially concerns short-term versus long-term credits. This is discussed in details and empirically estimated for Ukraine in section 4.2 . 


\subsubsection{Storage costs and interest rate developments}

The interest rates affect not only production costs and farm debts, but also the storage costs of the agricultural commodities. While the former determines mainly production costs through combination of different technologies, the latter affects both production costs and output prices. Storage costs directly influence the storable commodities and indirectly non-storable (perishable) commodities such as vegetables or meat through storable products such as feed. Prices, consumption, and production are all deeply affected by the presence of competitive storage, both at one moment in time and over time (WILLIAMS and WRIGHT, 1991).

Storage fulfils the different tasks (HENRICHSMEYER and WITZKE, 1991: 317):

- It allows to ensure the stable production and consumption of any firm;

- It moderates the seasonal price fluctuations; and

- It reduces price variations between 'good' and 'bad' harvests.

The effects of the storage are demonstrated in figure 16. In the absence of storage, 'bad' harvest reduces the supply of, for example, wheat in the short run from $S_{1}$ to $S_{2}$. As a result, the wheat price will jump from $P_{1}$ to $P_{2}$ (part b). The availability of stored stocks can dampen such price increase through supply of additional wheat to the market $\left(X_{L 1}\right)$. In this case, wheat supply is not fixed, but rather price elastic, i.e. the supplied quantity depends on the price that consumers are willing to pay $\left(S_{1}+S_{S}\right)$. In the case of 'bad' harvest and with new supply curve $\left(S_{2}+S_{S}\right)$, the wheat price will rise anyway, but the magnitude in the latter case $\left(P_{3}\right)$ is certainly less than in the former one $\left(P_{2}\right)$. Moreover, in contract to the situation without storage, consumers will retain more of their consumer surplus not only because of lower wheat prices, but also because of higher wheat supply $\left(X_{3}\right.$ instead of $\left.X_{2}\right)$.

Figure 16: Storage and price formation

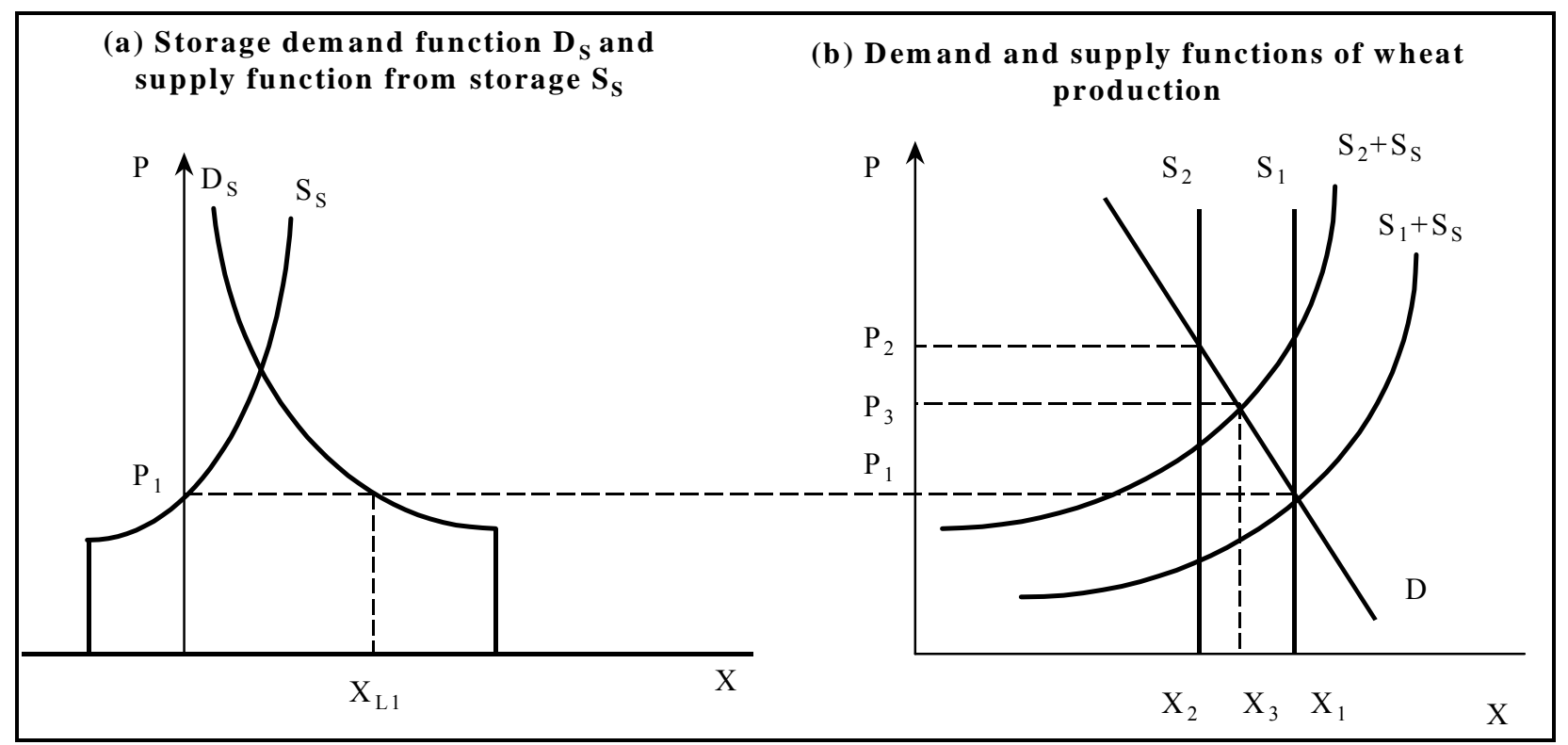

Source: HENRICHSMEYER and WITZKE (1991: 320) 
Thus, the storage costs fulfil important tasks by linking current and future agricultural prices. The general relationship for the prices of any storable product can be explained by using figure 17 . The price of corn - for example, $P_{t}-$ will be determined not only by its supply $S_{t}$ and demand $D_{t}$ within a particular time period, but also by supply from the storage $S S_{t}$ and demand from the storage facilities $D S_{t}$. At the same time, the stock's building and reduction depend not only on current output price $P_{t}$, but also on future price $P_{t+1}$ and storage costs. If the difference between future and current prices is larger than the storage costs, there would be a tendency to build up commodity stocks. Due to the increased demand, the current output price $P_{t}$ will rise as well. At the same time, the higher stored stocks will push down the expected future price $P_{t+1}$. $P_{t}$ will increase, and $P_{t+1}$ will be decreasing until the price difference equals storage costs (KOESTER and VON CRAMON-TAUBADEL, 2002).

\section{Figure 17: Relationship between prices over time}

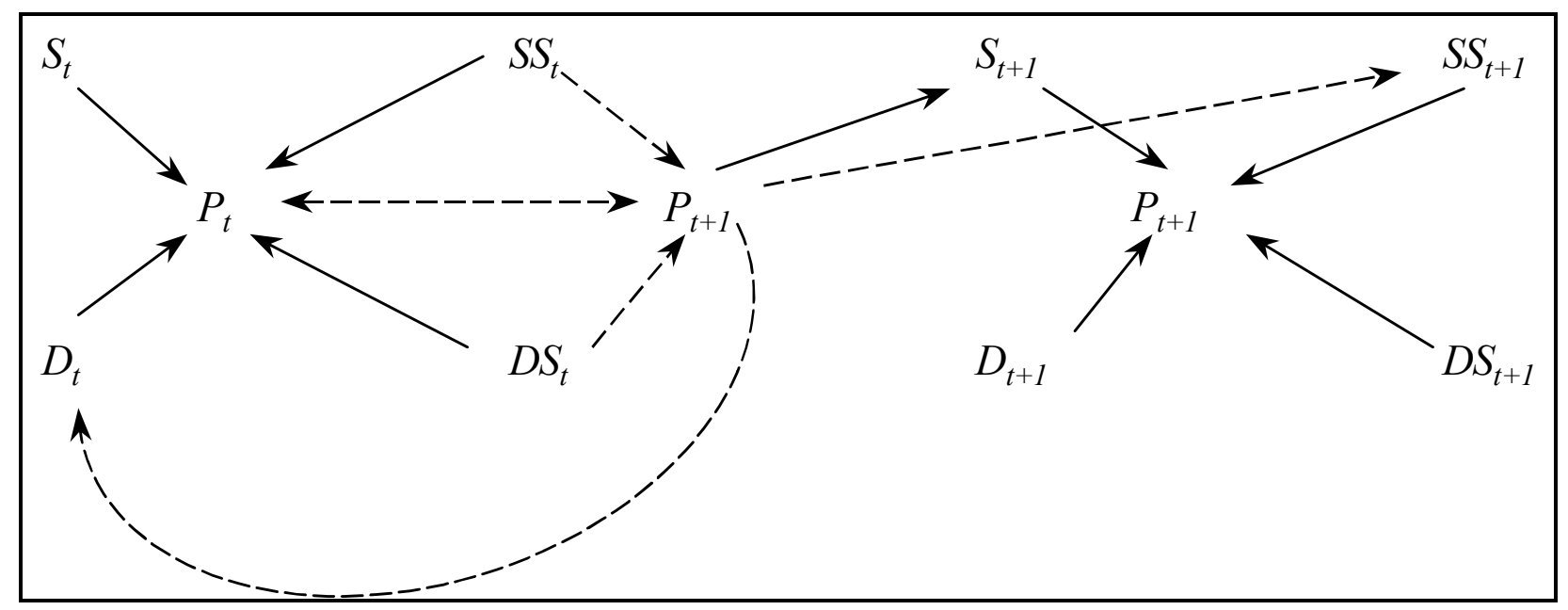

Source: $\quad$ KoEster and VON CRAMON-TAUBADEL (2002: 3).

The equilibrium steady-state on the commodity market is reached when the price difference is equal to the 'total storage costs' which include the costs of physical storage, interest costs, and risk premium. The equation (2.20) shows this relationship:

$$
\frac{P_{t+1}-P_{t}}{P_{t}}=s c+i+r \text { or } P_{t+1}=P_{t}^{*}(1+s c+i+r)
$$

where $s c$ is the costs of physical storage, $i$ is the real interest rate, and $r$ is the risk premium. If the future price of the commodity is lower than the current commodity price, discounted for the 'total storage costs', farmers are inclined to sell the commodity without storing it, and visa versa.

The interest rate is taken into account in total storage costs both explicitly and implicitly. The direct effect is evident - the interest rate $(i)$ is included to total storage cost by showing the opportunity costs of holding the stocks instead of selling crops and accumulating interest on cash holdings. When interest rate rises, the cost of holding commodities in storage increases likewise. It is clear that there is an incentive to sell farm products from the field and pay off money borrowed to buy inputs as opposed to storing commodities in hope of higher prices. 
The indirect effects are less visible. Marketing was essentially a non-issue in the USSR. Thus, the creation of efficient marketing infrastructure is an important task of the economic reforms in Ukraine to ensure higher market integration and higher farmer prices. High interest rates discourage investments and thus, hamper the modernisation of the elevators, transportation, ports, etc. In this way, higher interest rate may translate into greater physical costs of storing $(s c)$.

\subsubsection{Interest rates and land market}

Finally, the interest rates influence the price of agricultural land. Although agricultural land in Ukraine is not yet subject to purchase and sale,${ }^{10}$ understanding of the land price determination has important implications for individual farm operations at the microeconomic level, as well as for development of the agricultural sector and design of appropriate agricultural policies at the macroeconomic level in the future (VON CRAMONTAUBADEL and STRIEWE, 2001). The purchasing price of agricultural land derived from the rental price is the following:

$$
P_{p}=\sum_{t=1}^{\infty}\left[\frac{P_{r}}{(1+q)^{t}}\right]
$$

where $P_{p}$ is the purchasing price of a hectare of land, $P_{r}$ is the rental price of land, and $q$ is the discount rate that is used to discount future streams of income to derive their present value.

Equation (2.21) shows that the higher the discount rate is, the lower is the agricultural land price. The discount rate $(q)$ consists of two important elements agricultural policy element and interest rate on capital. From the one hand, unstable agricultural policies increase the discount rate through rising uncertainty about future income that the farmer will generate from a given hectare of land and thus reduces the purchasing price of land. On the other hand, high interest rates 'tax' land owners because (1) they increase the costs of agricultural production, thus reducing net income accrued to land and (2) "they discount future income when calculating the present value of the right to farm a hectare of land at certain future date" (VON CRAMON-TAUBADEL and STRIEWE, 2001: 204). Hence, high interest rates reduce both rental price of land and purchase land price that corresponds to any given rental price.

\footnotetext{
${ }^{10}$ In 2001 the new Land Code was adopted that allowed to sell and purchase the agricultural land since 2005 .
} 


\subsection{Agriculture and macroeconomic equilibrium}

Open-economy economics foresees interlinkages in both directions: from macroeconomy to agriculture and from agriculture to macroeconomy. The importance of former linkages was already demonstrated in sections (2.3) and (2.4) above. Real exchange and interest rates are of a paramount importance to farm decision-making, farm incomes, and consequently, agricultural policy. This section, in contrast, presents possible impacts of agriculture on the rest of the economy and stresses out that economic growth is hardly sustainable without an efficient agriculture. Generally, the impact of agriculture on the rest of the economy will depend on its size, of course. In the industrialised west, general economic effects are increasingly small except in regions that are very rural, though even in these countries, the impact of distortive agricultural policy should not be underestimated. As usual, this section begins with the literature overview.

\subsubsection{Literature overview}

\subsubsection{Agriculture and macroeconomics in developed economies}

Despite of the small share of the agriculture in developed economies, it still plays an important role in the overall economy. In the United States, for example, farming accounts for only $1.4 \%$ of GDP and $2 \%$ of the jobs. But farm production (the sum of inputs and farming) was $6.6 \%$ of GDP and $6.3 \%$ of the jobs in 1990 (KNUTSON et al., 1995). Assuming no reduction of the output, every $\$ 1$ bln increase of demand-driven gross farm income generates about \$3 bln of the additional GDP and 30-35 thousand jobs. "Moreover, each dollar earned from agricultural exports results in another $\$ 1.52$ of output in the U.S. economy" (LIPTON, 1991).

Similar to that how agriculture can contributes to the overall economic growth, distortions coming from agriculture can slowdown economic developments. Distortions in the developed countries are often triggered by the protectionist agricultural policy. In 2001 , for example, total farm support in OECD is estimated to equal \$258 bln or roughly $37 \%$ of the gross farm receipts (OECD, 2002). According to KOESTER (1991), farm support policies can be classified with respect to their side-effects. "Instruments from the class 1 positively contribute to farmers' income by encouraging more efficient use of farmers' resources. Farmers and a whole society benefit from such policies. Instruments belonging to class 2 transfer income from non-farmers to farmers, but without negatively affecting total income in the economy. Non-farmers may accept such policies on the basis of social arguments. Class 3 instruments also transfer income in favour of farmers, but non-farmers have to give up more than farmers gain. This type of policy makes society as a whole not better, but worse off' (KOESTER, 1991: 5).

The examples of the class 3 policies can be found in each OECD country. For example, "there are many years when the EU had to pay more for the imported feed needed for milk production than it received for the final product butter on world markets. All of the people and capital employed in mixing feed, transporting it to the farms, building stables for cows, feeding and milking cows, processing milk to butter and so on, did not help to increase welfare in the EU. Instead, this work was not only useless in economic terms, but other people, not directly involved in dairy business, had to incur losses in economic well-being" (KOESTER, 1991: 10). 
The impact of farm protection on the rest of the economy is often studied in the general equilibrium framework to estimate not only the direct costs of the farm protection, but also its effects on total employment, budget deficit or GDP growth. FELTENSTEIN (1989) studied the impact of the agricultural policy on the U.S. Federal Budget and U.S. trade deficit. He found that during 1985-86 the removal of all farm subsidies would reduce the U.S. budget deficit by $\$ 37$ bln or $16.7 \%$ in 1986 and improve the trade balance by $\$ 42$ bln or $27.8 \%$ in 1986 . The removal of the subsidies would result in a direct budgetary savings plus additional savings through its impact on interest rates and the tax base, while the improvements in the trade balance would steam from the impact of an increase in the real interest rate on domestic savings and investments, as well as a relative decline in the export price index. Feltenstein's foundings were supported by ROBINSON et al. (1989) and HERTEL et al. (1989), who also found the significant impact of probable liberalisation of the farm policies on the U.S. economy.

VINCENT (1989b) analysed the influence of large farm protection in Japan on the competitiveness of non-agricultural trade activities in the 1980s. He found that farm protection implicitly taxed Japanese manufacturing, particularly the sectors producing and exporting transport equipment, other machinery, mineral and metal products, and chemical products. The tax was sufficient to curtail manufacturing export earnings by about 3\%. This led to the reduction of output in these sectors over the short or medium term between 0.3 to $2 \%$ and reductions in manufacturing employment demand from 0.4 to $4 \%$.

VINCENT (1989a) studied the interlinkages of agricultural protection in Korea and non-agricultural exports in the 1980s. High farm protection in Korea (in 1984 the nominal rate of agricultural protection equalled to $137 \%$ ) substantially reduced real wages and international competitiveness of Korean export activities. If agricultural protection were removed, real wages would increase by about $6 \%$ in 1987. Aggregate export earnings would increase by nearly $9 \%$ and the total employment would rise by more than $8 \%$.

The fiscal burden of the Common Agricultural Policy (CAP) has inspired substantial analyses of the impact of agricultural protection on macroeconomic variables in studies such as GYLFASON (1995) and STOECKEL and BRECKLING (1989). GYLFASON argued, that although partial equilibrium analysis has revealed the dead-weight losses resulting from farm policies represented about $1 \%$ of GDP, long-term general equilibrium considerations show an estimated loss to $3 \%$ of GDP. The CAP has been 'responsible' for higher consumer food prices and the increased tax burden. "Total per capita agricultural transfers per full-time farmer equivalent averaged $\$ 17700$ in the EU, compared with the median labour income of \$12000 in 1992" (cited in SCHIFF and VALDES, 1999).

STOECKEL and BRECKLING (1989) examined the effects of removing both the CAP and national agricultural protection in the four largest EU countries, namely Germany, France, Italy and the UK. They found that the elimination of either measures of protection could generate an increase in aggregate output of over $1 \%$, create $3 \mathrm{mln}$ new jobs, and lead to a $5 \%$ increase in manufacturing exports to the rest of the world.

DICKE et al. (1989) focused on the case of West Germany, the largest economy in the EU and the largest contributor to the CAP. They found that Germany would 
experience gains from liberalisation similar to those estimated by STOECKEL and BRECKLING. Total public subsidies to German agriculture equalled to about $70 \%$ of the sector's gross value-added at domestic prices. Assuming an increase of $10 \%$ in world agricultural prices and constant wages, agricultural liberalisation would result in a reduction in the rate of unemployment from 9 to $5 \%$, along with a $3 \%$ gain in real GDP and a 5\% increase in foreign trade. Given the small share of agriculture in the economy of the EU and Germany, the effects found in the above studies seem to be large indeed.

\subsubsection{Agriculture and macroeconomics in developing and transition countries}

In the developing countries, where agriculture, in contrast to the developed economies, usually accounts for a large share of the total GDP and employment, farmers are often subject to high explicit and implicit taxation. Taking into account the role of agriculture, this farm taxation leads to the overall economic contraction. Based on SCHIFF and VALDES (1992)'s analysis of 18 developing countries, high taxation of agriculture resulted in lower agricultural output (2.7\% per year) and lower growth of GDP (4.2\% was the average GDP loss for countries with "very high" and "high" rates of agricultural taxation). In the countries with relatively low farm taxation, agricultural sector annually grew $5.2 \%$, while the overall economy by $5.9 \%$ per year in average. "If these results can be generalised, they suggest that agricultural growth rates can be nearly doubled by ending heavy taxation of the sector. In turn, the growth rate of GDP will increase by about 2\% per year" (BLOCK and TIMMER, 1997: 2-6).

Many studies emphasise the distinct various effects of agricultural growth on the rest of the economy. The most satisfactory approach to measuring so-called "non-market impact" of agriculture on economic growth is demonstrated in recently developed theories of economic growth, which are summarised in BARRO and SALA-I-MARTIN (1995). Typically empirical specifications of modern growth models control for initial conditions, factor accumulation, and quality improvements in labour and capital and then proceed searching for control variables that affect the overall efficiency of resource allocation. Although BARRO and SALA-I-MARTIN did not include agricultural growth as an explanatory variable of the overall economic growth, the efforts to correct this omission are reported in HWA (1988), DAWE (1993) and CHAI (1995). HWA found that the agricultural productivity had larger significance in explaining growth in total factor productivity than inflation or openness, though the others were also significant. CHAI found that 'good' policy with respect to reversing urban bias raised the rate of economic growth per capita by $1.46 \%$ per year. Considering a sample of seventy developing countries within the period of 1960-1985, a highly significant positive relationship was observed between growth in the agricultural sector and in the non-agricultural sector; about $20 \%$ of the growth rate in agriculture was added to the exogenous growth rate in non-agriculture. "Urban bias in government policy contributes roughly one-third of the differences in economic performance between countries that have very rapid growth in income per capita and those that have suffered stagnation or retardation. This positive relationship between that rate of economic growth and growth in rural economies is clearly found in the historical record" (cited in TIMMER, 1998b: 201).

Although the impact of the non-market linkages on economic growth is difficult to disaggregate, CHAI (1995) tested the positive effects of growth in agricultural 
productivity through disaggregation of human capital into rural and non-rural components and found that rural human capital is much more important than non-rural human capital in explaining differential growth rates of income per capita in developing countries. According to the author, an improvement of urban human capital seems not to contribute to economic growth when the level of rural human capital is held constant, "probably because such increase would further increase the degree of urban bias, which has a strongly negative effect on economic growth" (TIMMER, 1998b: 203).

In comparison to the developed and developing countries, there are only few such empirical studies for CEE transition economies. Four studies could be mentioned in this respect. BANSE (2000) analysed the macroeconomic implications of purely agricultural element in the EU accession of all CEE countries by using the CGE model. The author demonstrated that along with the impact of the net trade position to country's economic welfare (net exporters gain, while net importers lose due to the financial solidarity mechanism under the CAP), the EU accession would affect the CEE countries' GDP, RER, and the investment rates. For example, accession to the CAP is expected to result in the appreciation of the RER by $2.3 \%$ in Hungary (mainly due to financial inflows from Brussels), and a depreciation of the RER in Slovenia by $1.0 \%$ (mainly because of financial outflows to Brussels). Gross investments in the overall economy will probably rise by $1.7 \%$ in Hungary, while the may fall by $4.1 \%$ in Slovenia. In the case of extension of direct payments to the acceding countries, the Polish zloty, for instance, would appreciate by $2.8 \%$ in contrast to $0.5 \%$ of real depreciation in the case of the CAP accession without the extension of direct payment scheme. Gross investments in the overall economy of Poland might expand by extra $4 \%$ compared to a situation in which direct payments were not made (BANSE, 2000).

ZORYA (2001a) analysed the impact of inefficient farmers and agricultural policy in Ukraine on the current account sustainability. In particularly, it was found that intensive state financing of the agriculture, bad payment discipline of the farms, inwardoriented agricultural trade policy and weak private ownership on land and assets had greatly contributed to the current account imbalances over 1994-1999 and the financial crisis in the mid-1998.

SWINNEN and GOW (1999: 21) described the agricultural credit problems during the transition in Central and Eastern Europe and stressed out the negative contribution of the agriculture to the high levels of the interest rates and credit unavailability: "The high interest rates reflect both transition and structural problems with CEE agriculture. Lack of collateral, low profitability and macroeconomic uncertainty makes the banks view the agricultural sector as a high risk consumer. Expected declining profitability and macroeconomic uncertainty are discouraging borrowing at high nominal interest rates. Immediate plans of farmers are uncertain because of the lack of working capital. There is also the long-term problem of ensuring adequate funds to facilitate structural adjustment and to enable farmers to apply effective technologies".

When in most CEE countries many private farmers and large scale farm managers would name 'high interest rate' as the main constraint in accessing credits (see SWINNEN and GOW, 1999; PETRICK, 2002), in Ukraine, where the capital market and banking system in general are among the weakest in the world (LEVINE, 1997), the farmers' complaint over high interest rates is probably even stronger. In this context, STRIEWE et 
al. (2001a) also pointed out the responsibility of farmers for their low bank financing in Ukraine. Commercial banks were reluctant to credit farms with low profitability and thus, poor creditworthiness, while many farms with good performance could receive banking credits even at high interest rates (see also section 2.4.1.2).

Various linkages explored in this literature overview are structured in the theoretical analysis below.

\subsubsection{Linkages between agriculture and non-agriculture}

The influence of agricultural performance on economic growth remains significant well into development process. TIMMER (1998a) points out at least four phases of agricultural transformation. It begins when the agricultural productivity per worker increases and "agriculture starts moving" (MOSHER, 1966). "The increased productivity creates a surplus, which in the second phase can be tapped through taxation and factor flows. This surplus can be utilised to develop a non-agricultural sector. This second phase has been the focus of most of the dual economy models of development. For resources to flow out of agriculture, rural factor and product markets must become better integrated with those in the rest of the economy. The integration of the agriculture into the macro economy via improved infrastructure and market-equilibrium linkages, represents a third phase in agricultural development. When this phase is successful, the fourth phase is barely noticeable; the role of agriculture in industrialised economies is little different from the role of steel, housing, or insurance sector" (TIMMER, 1998a: 116).

As agricultural transformation is always 'continuous', its impact on the rest of the economy is changing as well. Hence the impact of Ukrainian agriculture on macroeconomy will vary over different phases of the transformation. Successful transition of Ukrainian agriculture from a planned to a market economy will contribute to the overall economic transition. In contrast, the extraction of the resources from the rest of the economy will hardly help to complete transition, but rather dampen its process. After the transition from a planned to a market economy is 'successfully' completed, it does not mean that the agriculture would stop contributing to the relatively developed rest of the economy. Even in the developed countries, farmers continue to contribute to the overall economic growth through different channels. In general, the agricultural growth contributes to the total factor productivity in non-agriculture through (1) competitive costs structure, (2) stability, and (3) growth in agricultural productivity (HwA, 1988; BLOCK and TIMMER, 1997).

Two broad categories of linkages create these connections. The first are the traditional market-mediated linkages that form the core of economic analysis of the role of agriculture in economic development. These are often divided into LEWIS linkages, which operate through factor markets that transfer labour and capital from agriculture to industry, and JOHNSTON-MELLOR linkages, which operate through product markets (TIMMER, 1998a). The factor-market linkages between agriculture and industry have been so important to the growth process that they led LEWIS (1954) to the following observation: "Industrialisation is dependent upon agricultural improvement; it is no profitable to produce a growing volume of manufactures unless agricultural production is growing simultaneously. This is also why industrial and agrarian revolutions always go 
together, and why economies in which agriculture is stagnant do not show industrial development" (cited in TIMMER, 1998b: 200).

The traditional market-mediated linkages are listed in JOHNSTON and MELLOR (1961):

(1) the increase of food supply for domestic consumption; (2) the release of labour for industrial employment; (3) the enlargement of the size of the market for industrial output; (4) the increase of the supply of domestic savings; and (5) earning of foreign currency.

The second category of linkages is often called non-traditional. They focus on a set of nebulous and hard-to-measure connections between growth of agricultural productivity and rest of the economy. Considering such linkages, the contribution of agricultural growth to productivity growth in the non-agricultural economy originates from at least five sources: (1) the contribution to learning by doing, both by governments and firms; (2) food security and political stability; (3) greater efficiency in decision making as rural enterprises claim a larger share of output; (4) higher productivity of industrial capital as urban bias is reduced; and (5) higher productivity of labour as nutritional standards improve. ${ }^{11}$

Table 5 presents the detailed explanation of agricultural growth linkages. The three basic ingredients (cost structure, stability, and agricultural productivity) are interlinked and interdependent. They all influence the macroeconomic stability and can induce the economic growth, though at different stages of agricultural transformation, the macroeconomy is affected by agricultural sector differently (depending on the integration of the agriculture into the general economy, for example).

${ }^{11}$ See BLOCK and TIMMER (1997) details on both traditional and non-traditional linkages. 


\section{Table 5: Agricultural growth linkages to the economy's total factor productivity}

$\mathrm{TFP}_{\text {nag }}=\mathrm{f}[$ Cost Structure; Stability; Agricultural Productivity $\mathrm{ag}]$

A. Cost structure

1. Capacity utilisation

- raw materials

- foreign exchange for imported inputs

- labour supply

2. Competitiveness pressure

- openness of economy

- domestic regulations

- size of economy (small is less competitive)

3. Technology

- research and development

- extension and education

- exogenous

B. Stability

1. Macro stability

- inflation or variance of inflation

- export instability

2. Food price stability

- macro effects

- political economy effects

C. Agricultural productivity

1. Learning by doing

- government

- industry with captive domestic market

2. Food security and reduced price instability

3. Efficiency of rural decision making

- low costs of household resources in non-farm activities

- uncounted investments in rural areas

4. Effects on capital productivity of reducing urban bias

- shifting investments from low productivity in the urban economy to high productivity in the rural economy

5. Effects on labour productivity of improved nutrition 


\subsection{Summary of the chapter}

Macroeconomic policy plays an important role in determining agricultural sector performance world-wide. The real exchange and interest rates are especially distinctive for capital-intensive sector that produce tradable goods, such as that of agriculture. As these macroeconomic variables reflect the general economic climate in the country, observations for their development over time are very useful for designing agricultural policy and making efficient farm decisions.

These variables are especially important in a market economy, where the policy makers cannot know what consumers want and what producers should produce. Rather, in a market economy, it is the prices of different goods and services, and in particular their relative prices, that guide demand for goods and services by consumers and supply from producers. But for this process to work efficiently, it is essential that the price system be protected from macroeconomic disorder.

To study the effects of macroeconomic policy on agriculture, a list of the theoretical concepts within a general equilibrium framework is used. Theoretical framework for studying the impact of RER on agriculture consists of the Dependent Economy Model and the Krueger-Schiff-Valdes approach. The former model examines intersectoral linkages and resource flows in a small open economy such as Ukraine and highlights the role of the RER in determining agricultural growth. The latter concept provides the base to study the effects of RER misalignment on agricultural incentives. The world-wide experience demonstrates that these effects could be large indeed and often could even exceed direct effects of the agricultural policy.

A presentation of the theoretical foundations to study an impact of real interest rates on the agricultural sector starts with the consideration of macroeconomic linkages in an open economy within the Mundell-Fleming model. Complex relationships between interest rates, capital inflows, exchange rates, investments and production urge that policy makers abstain from making sectoral-specific decisions without taking into consideration their economy-wide effects. After macroeconomic effects are enlighten, agriculture specific issues at micro level are considered, including the relationship between interest rate and production costs, farm debts, storage costs, and land prices. In such a transition country as Ukraine, the interest rate plays an important role in allocating scarce capital to the most efficient users. If the policy makers intervene and distort interest rate incentives (e.g. interest rate subsidisation), losses in social welfare are inevitable.

Often the agriculture is 'taxed' by macroeconomic disorder, initially initiated by agricultural sector itself. Or, in the other words, similarly as the macroeconomics determines agricultural growth, agricultural development may influence overall economic development, in turn. There are different type of linkages between agriculture and overall economy that could be grouped into traditional market-mitigated linkages and nontraditional linkages. At different stages of the economic development, agriculture contributes to the economic growth through various linkages and these linkages are in evolution themselves. Even in developed economies where the role of agriculture is relatively small, distortive agricultural policies diminish overall social welfare. But in the countries where the agriculture occupies an important place in the system of national 
accounts, 'weak' farm performance may initiate overall long-term economic disorder, which is difficult to overcome without structural reforms in the agricultural sector.

The next chapter considers the transition of Ukrainian economy from a centrally planned to a market economy with a special attention to the macroeconomic variables highlighted in this theoretical chapter, as well as to the distinct issues of agricultural development which are important in considering the role of Ukrainian agriculture in overall economic development over the last decade. 


\section{Ukrainian Economy in Transition}

This chapter describes the development of Ukrainian economy in general and agriculture in particular since obtaining Independence. An analysis of the overall economic development and macroeconomic policies is followed by an overview of the main trends of agricultural transformation with respect to farm performance and agricultural policy. This analysis permits a linkage of the development in farm and nonfarm sectors and it provides the information required for the empirical part of the dissertation.

\subsection{General economic performance in Ukraine}

An overview of general economic development in Ukraine over 1991-2001 begins with an explanation of GDP development. It is analysed by considering fiscal, monetary, exchange rate, and trade policies of the country. After this macroeconomic overview, an analysis of agricultural sector performance will be conducted.

\subsubsection{Development of gross domestic product in Ukraine}

Developments of Ukrainian GDP can be divided into two distinct phases: firstly, a severe output contraction during 1991-1999 by 74.3\% and secondly, a sharp GDP growth (see figure 18). ${ }^{12}$ Especially deep GDP decline was observed in the first years of transition. Later, during 1996-1998, the decline slowed down. In the mid-1998 Ukraine went through the financial crisis that marked the beginning of the economic recovery. After a number of liberal reform steps were undertaken by the GOU in 2000 and 2001, accumulated real GDP growth over 2000-2002 reached 19\%.

Ukraine's output performance follows the expected U-shape for the transition economies. The period of initial output decline is followed by the output recovery, but being an "intermediate" reformer Ukraine is only in the middle of this curve in comparison to more advanced transition economies (HAVRYLYSHYN et al., 1999). Figure 19 demonstrates that all countries of the Central and Eastern Europe went through an initial output decline. But after that changes in output diverged strongly: while several countries have recorded growth after four years of transition (Poland, Slovenia, Slovakia, Hungary, and Czech Republic), real output in Ukraine, as well as in Bulgaria, Romania, and Russia was declining until 2000. "While advanced reformers, at the end of the Ushape, are reaping the benefits of the new market environment, and are generally showing sustained growth, Ukraine just started to grow 'wasting' several years to create an environment conductive to growth" (HAVRYLYSHYN et al., 1999: 13).

\footnotetext{
${ }^{12}$ Of course, official Ukrainian statistics on GDP should be interpreted with caution. JOHNSON et al. (1997) found that a shadow economy accounted for roughly 49\% of Ukraine's GDP in 1995. The State Statistics Committee of Ukraine increased the official GDP estimate by $20 \%$ from the shadow economy in 1999, while MELOTA and GREGORY (2001) raised the estimation in that year to $32 \%$.
} 
Figure 18: Changes of real GDP in Ukraine, 1991-2002, (in \% to previous year)

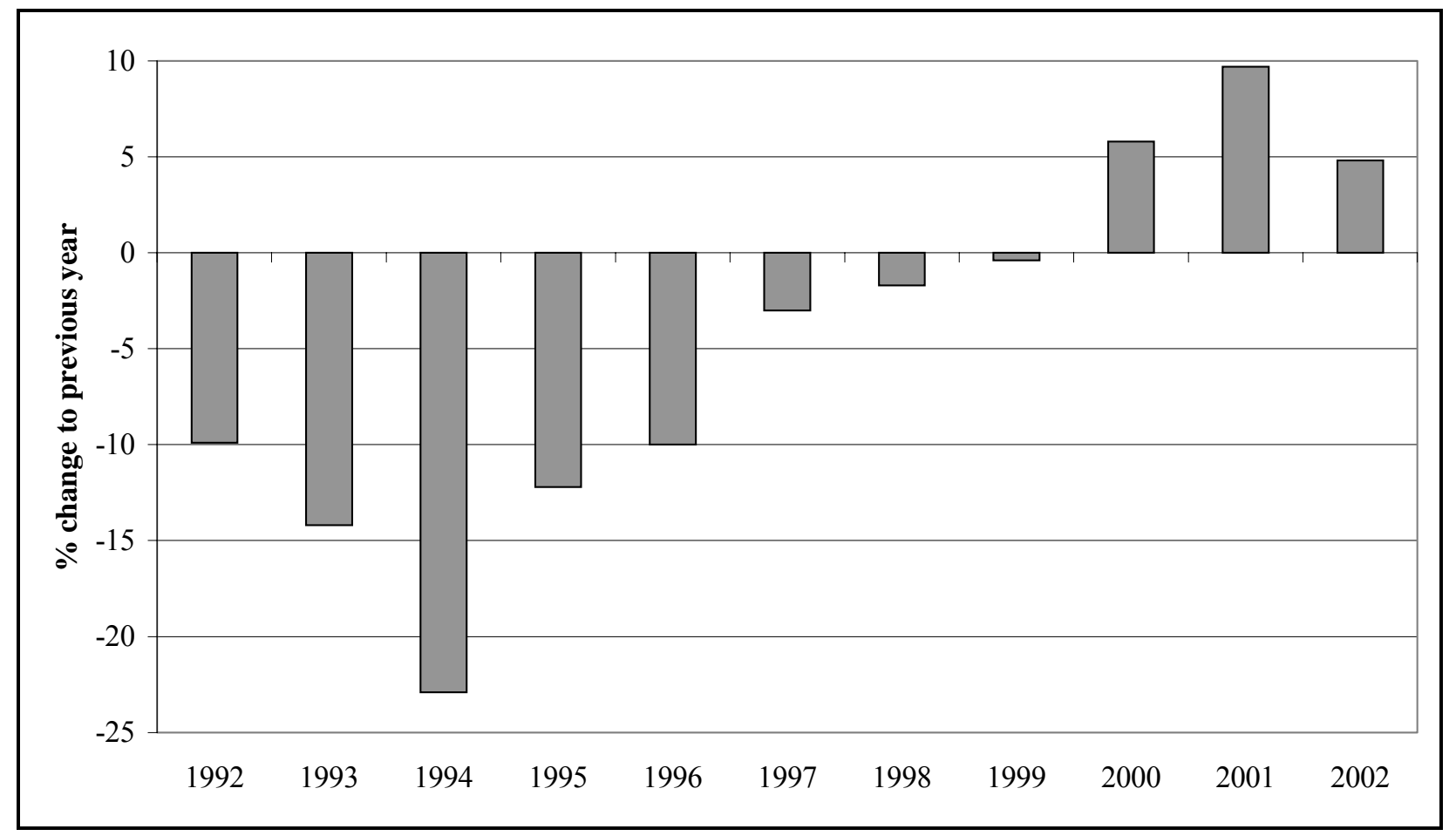

Source: $\quad$ UEPLAC (2002) and IER (2000-02).

Figure 19: Changes in real GDP in selected CEE countries, 1989-2001, (in \%)

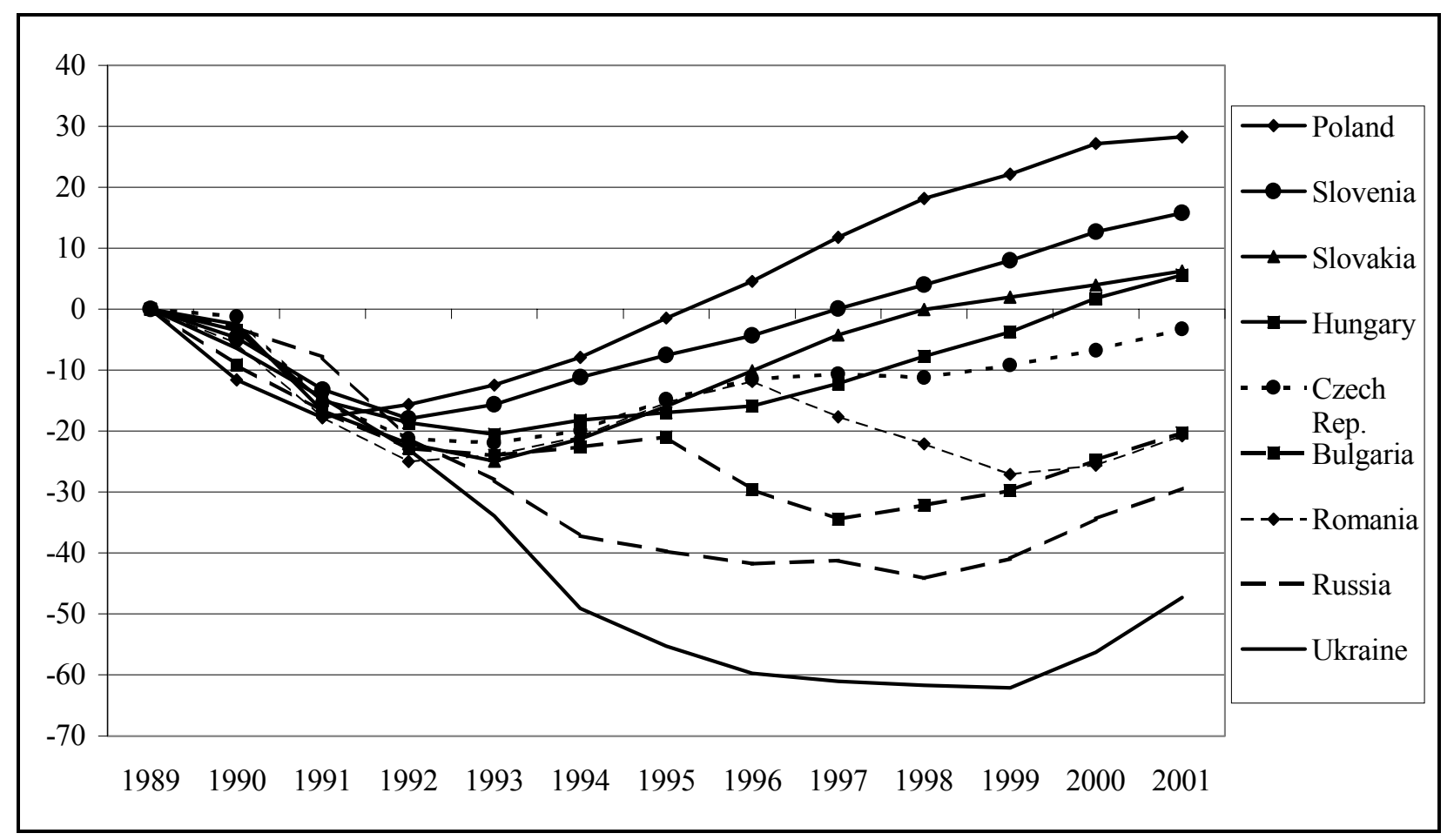

Source: $\quad$ SwINNEN (2001: 7) and DBR (2002).

Recent literature on the growth in the transition economies is very broad and the following variables are typically included in the regressions to explain the different countries' performance: initial conditions; inflation representing macroeconomic policy; 
index of structural reforms; and size of the government measured by government expenditures in percent of GDP, representing factors such as crowding out, distortions through high taxation and large bureaucracies (DE MELO and GELB, 1996; SACHS, 1996; FISCHER et al., 1998; BERG et al., 1999; HAVRYLYSHYN et al., 1999). The main conclusions of these studies are that (1) while initial conditions seriously influenced transition, their influence is mostly on output changes and less on productivity developments; (2) as transition progresses, structural and macroeconomic reforms compensate the influence of initial conditions; ${ }^{13}$ and (3) the countries which pursued reforms faster and more thoroughly are currently performing better. In the sections below, developments of the macroeconomic policy in Ukraine will be described and analysed to help explaining the GDP shape and, further, the agricultural performance.

\subsubsection{Fiscal policy in Ukraine}

The legacy of the Soviet system left a trace on post-soviet fiscal policy in Ukraine. Although the GOU often stated that fiscal stabilisation was a precondition for successful economic transformation, in practice, the fiscal reforms often lagged political statements. Actually, the weakness of the whole fiscal system was among the most important determinants of the economic contraction throughout the 1990s (PYNZENYK, 2000). Financing of the budget deficit though 'printing off' money and attracting short-term capital inflows greatly diminished the sustainability of such a policy and resulted in the financial crisis of 1998. Although the recent changes in fiscal policy are for the better, it can still hardly be called growth-oriented, balanced, and transparent. In spite of the substantial reduction of government expenditures as a share of GDP, they remain high from an international perspective (SULTAN, 2000), and until 2000, these expenditures continued to be higher than the actual budget revenue. Moreover, the 'hidden' deficit was the norm due to the accumulation of the budget arrears. In contrast, 'relative' fiscal discipline in 2000 and 2001, when the budget was in surplus, seemed to be among the origins of the economic growth. The key indicators of the fiscal policy in Ukraine are summarised in table 6 .

${ }^{13}$ The impact of the adverse initial conditions was significantly negative on Ukraine's growth (see OdLING-SMEE and VAN ROODEN, 1999 and HAVRYLYSHYN et al., 1999). But this effect could have been easily overcome by stepping up structural reform policies. The additional reform effort would require the reform index to be increased from a level of 0.57 in 1997 to 0.64 , which is comparable to the level of more advanced reformers of the CIS, but which is still less than the levels reached in CEE (0.73 on average in 1997). Alternatively, to compensate for the relatively worse initial conditions, the size of the government could be reduced by about $8 \%$ of GDP from $42 \%$ of GDP in 1997 to $34 \%$ of GDP, which is still higher than CIS average of $28 \%$ of GDP. Of course, combination of both policy responses could be chosen as well to achieve the same result. 
Table 6: Key indicators of the fiscal policy in Ukraine, 1992-2001

\begin{tabular}{lcccccccccc}
\hline & $\mathbf{1 9 9 2}$ & $\mathbf{1 9 9 3}$ & $\mathbf{1 9 9 4}$ & $\mathbf{1 9 9 5}$ & $\mathbf{1 9 9 6}$ & $\mathbf{1 9 9 7}$ & $\mathbf{1 9 9 8}$ & $\mathbf{1 9 9 9}$ & $\mathbf{2 0 0 0}$ & $\mathbf{2 0 0 1}$ \\
\hline $\begin{array}{l}\text { Consolidated budget } \\
\text { revenues, UAH bln }\end{array}$ & 0.02 & 0.57 & 5.31 & 20.43 & 30.14 & 36.89 & 37.40 & 43.83 & 62.94 & 72.12 \\
$\begin{array}{l}\text { Consolidated budget } \\
\text { expenses, UAH bln }\end{array}$ & 0.02 & 0.66 & 6.45 & 24.44 & 33.76 & 43.09 & 39.42 & 45.33 & 61.05 & 71.55 \\
$\begin{array}{l}\text { Consolidated budget } \\
\text { balance, UAH bln }\end{array}$ & 0.00 & -0.09 & -1.14 & -4.04 & -3.62 & -6.20 & -2.02 & -1.70 & 1.89 & 0.57 \\
\hline $\begin{array}{l}\text { Budget revenues as a } \\
\text { share of GDP, \% }\end{array}$ & 32.8 & 40.0 & 49.1 & 40.1 & 38.6 & 42.4 & 39.6 & 37.0 & 40.4 & 37.7 \\
$\begin{array}{l}\text { Budget expenses as a } \\
\text { share of GDP, \% }\end{array}$ & 45.0 & 46.5 & 59.7 & 48.0 & 43.2 & 49.6 & 41.7 & 38.4 & 39.2 & 37.3 \\
$\begin{array}{l}\text { Budget balance as a share } \\
\text { of GDP, \% }\end{array}$ & -12.0 & -6.5 & -10.6 & -8.0 & -4.6 & -7.1 & -2.1 & -1.4 & 1.2 & 0.3
\end{tabular}

Note: $\quad$ The fiscal indicators include the payments to the State Pension Fund.

Source: UEPLAC (2002).

\subsubsection{Budget revenues}

Although during the observed period the budget revenues always increased in the nominal terms, budget revenues as a share of GDP hardly grew. ${ }^{14}$ The average share of the budget revenues in Ukraine's GDP during the observed period was $37.8 \%$. Actual revenues were chronically lower than the planned ones: for example, from 1997 to 1999 the planned budget income was realised only at 89.2, 95.6 and $94.4 \%$ respectively (ZHYLYAEV and ORLOVA, 2000). The main sources of the budget income have been the value-added tax (VAT), enterprise profit tax, excise tax, Chernobyl Fund tax, income tax, and Pension Fund tax. The cumulative share of these taxes in total revenue decreased from $89 \%$ in 1992 to $61 \%$ in 2001 (UEPLAC, 2002).

Initially the major sources of the budget incomes were the VAT, enterprise profit tax, and the Pension Fund tax, while the importance of the personal income tax was negligible in comparison to the developed countries. Gradually, revenue sources switched to the payroll taxes as the incomes from the VAT and the enterprise profit tax have been decreasing. Main reasons of this switching were the following:

- $\quad$ Proliferation of the non-monetary transactions;

- Growth of rent-seeking interests;

- Gradual reduction of the number of the profitable enterprises, and their rate of profitability; and

\footnotetext{
${ }^{14}$ Although 1993 and 1994 are out of this trend, a sharp increase of the budget income was rather a result of the strong GDP decline (-14.2 and -22.9 correspondingly) than the revenue increase. The real increase took place only in 2000.
} 
- $\quad$ Finally, as the budget income was not enough to cover the planned expenses as well as to inject 'easy' money to the inefficient enterprises, tax breaks and debt written offs proliferated, with their peaking in 1998 and 1999.

One of the disturbing factors in the Ukrainian tax system was the use of the barter or mutual cancellations as the means of paying taxes. Many of these involved offsetting taxes for bartered goods and services, particularly energy; or, on the opposite side, offsetting the state's arrears on pensions against pensioners' arrears on utility bills and apartment rent. So-called 'kartoteka-2, ${ }^{15}$, along with the low personal incomes are often mentioned as the reasons for these non-monetary transactions (SULTAN and PASIKA, 2000). The most critical fact was that the state itself had been at the heart of the nonmonetary syndrome (BOSS, 2000; SZYRMER, 2000).

The volume of the non-monetary transactions with the budget was frustrating. Its share in the total budget revenues increased from $4 \%$ in 1995 to $23 \%$ in 1999 (ZHYLYAEV and ORLOVA, 2000: 57). This growing tendency resulted in the gradual reduction of the budget revenues and, simultaneously, in higher levels of rent-seeking behaviour and corruption. The negative impact of non-monetary transactions on the economic growth came through distortions of the prices in the economy, under-fulfilment of the planned budget revenues, decrease of the transparency of the budget management, and anticipation of the future 'settlements' with the prolongation of activities of the bankrupt companies (IMF, 1999; BOSS, 2000; ZHYLYAEV and ORLOVA, 2000).

Along with the non-monetary transactions rent-seeking behaviour in Ukraine increased. A new class of the rent-seekers emerged from the corrupt Soviet system (LEVINE and SZYRMER, 2000), simply adapting itself to the new economic conditions (ASLUND, 1999, 2002). "The power of these interests was reflected in the tenacity and creativity with which they persuaded the government and the parliament to prevent reforms that would threaten their position" (VON CRAMON-TAUBADEL and ZORYA, 2001: 28).

'Soft budget constraints' allowed many enterprises either not to pay taxes at all or generate tax arrears. Before 1991, enterprises and individuals in the USSR did not pay taxes in the modern sense. Consequently, building up a functioning fiscal system to fund public institutions in a non-inflationary way has not been an easy task (Boss, 2000). Since the GOU did not have enough budget income to 'support' loss-making enterprises, it tried to collect too much revenue from the profitable businesses and redistribute it to inefficient enterprises. Generally, the situation in Ukrainian economy did not differ significantly from the Soviet time in the sense of the role of the state: the enterprise sector was kept dependent on centrally-distributed resources and concessions. In such a system the effectiveness of the whole economy entirely dependent upon an effectiveness of the government, while the role of the private sector was severely limited. And if the government did not work effectively enough, the whole economy appeared at lower efficiency.

15 'Kartoteka-2' is the operation which establishes commercial banks direct compulsion block any business transactions before the tax payments. To avoid the tax payments and to fulfil the contract commitments, the enterprises used barter operations. In 2001, 'kartoteka-2' was cancelled. 
Tax arrears were the norm for such an economy, while enterprises, entrepreneurs, and workers in the shadow economy did not pay taxes at all. For example, in 1999 (1995) the total tax arrears as a share of GDP reached $14.7 \%(2.2 \%)$ or $37.1 \%(5.6 \%)$ of the consolidated budget revenue (IMF, 1999). In addition to tax arrears, the exemptions, amnesties and negotiated ad hoc rates were popular instruments which substantially reduced the budget revenues. These exemptions especially proliferated in 1998 and 1999. As the former Minister of Economy TYHIPKO stated in early December 1999, the value of tax exemptions at over UAH 30 bln was comparable in magnitude to the central government's entire revenue (cited in BOSS, 2000). DOWNEY (1999) estimated the tax break losses as a share of the budget income at up to $105 \%$ in 1998 and $90 \%$ in 1999 .

In 2000 and 2001, the budget policy was reformed, and many tax exemptions and barter transactions were cancelled. In 2000, the share of tax break losses decreased to $28 \%$ of the budget income (DOWNEY, 1999) and the budget income reached its record level of $40.4 \%$ of GDP (see table 6 ). The economic growth during this period helped to ensure stable budget incomes, while still existing tax privileges continued to burden tax payers who did not have them. "At the beginning of 2001, around $17 \%$ of the enterprises in Ukraine gained from different tax privileges that resulted in the budget losses at the amount of UAH 30 bln" (HOFFMANN and VINCENTZ, 2002: 467).

\subsubsection{Budget expenditures}

After their peak in 1994 (59.7\% of GDP), the state expenditures decreased to about 38\% in 1999-2001, although before 2000 expenditures remained higher than the actual budget revenues (see table 6). The main directions of the budget expenditures were social transfers, economy subsidies, and education and health expenditures. Generally, the share of the expenditures directed to the tradable sector has decreased from $30.8 \%$ in 1992 to $13.6 \%$ in 2001, while the share of the non-tradable sector expenditures increased by $15.6 \%$ during the same period (UEPLAC, 2002). ${ }^{16}$

In spite of the cuts, the GOU expenditures are still high in comparison to other CEE and CIS countries, which shows the preponderant role of the government in the economy. In 1997, for example, the share of the state expenditures in GDP in all transition economic equalled roughly $36 \%$, in the CEE countries $-41 \%$ and in the CIS 30\% (ODLING-SMEE and VAN ROODEN, 1999: 15).

In addition, large portion of the expenditures are heavily titled towards unproductive sectors, such as subsidies to enterprises, large bureaucracy, and an untargeted social safety net. Expenditures on infrastructure and adequate wages for 'essential' staff are relatively modest. In the structure of expenditures, the social transfers prevailed (around 25\% of GDP during 1992-2001). Until 1999, the actual social expenditures did not reach their planned levels. The state itself was an example of the non-payment culture. For example, the state wage and pension arrears together reached

${ }^{16}$ Generally tradable sector is represented by the national economy, while the non-tradable sector - by social transfers, infrastructure, health and education, military and policy, foreign debt servicing, etc. But share of tradable sector is probably overestimated, as most subsidies to the tradable sector were used for the non-tradable objectives: wage payments or social infrastructure maintenance. 
$2.9 \%$ of GDP in 1998 , even exceeding the ex post consolidated budget deficit in $2.6 \%$ of GDP. In December 1999, the state's overdue wages and pensions, though reduced from their peaks, still amounted to $1.5 \%$ of GDP versus $1.4 \%$ budget deficit (SULTAN and PASIKA, 2000). The social debts accumulated in the budget substantially changed the real value of the budget deficit (table 7).

Table 7: 'Real' budget deficit in Ukraine, 1995-1999

\begin{tabular}{lllllc}
\hline & $\mathbf{1 9 9 5}$ & $\mathbf{1 9 9 6}$ & $\mathbf{1 9 9 7}$ & $\mathbf{1 9 9 8}$ & $\mathbf{1 9 9 9}$ \\
\hline \hline Official budget deficit, UAH mln & 4043 & 3167 & 6169 & 2065 & 1696 \\
Increase of the budget debts, UAH mln & 1756 & 3195 & 1954 & 2435 & -781 \\
'Real' budget deficit, UAH mln & 5799 & 6812 & 8150 & 4500 & 1145 \\
Real budget deficit as a share to GDP, \% & 11.4 & 8.7 & 9.4 & 4.8 & 1.0 \\
$\begin{array}{l}\text { Difference between official and real budget } \\
\text { deficit, \% }\end{array}$ & 3.5 & 4.1 & 2.3 & 2.2 & -0.4 \\
\hline
\end{tabular}

Source: $\quad$ SULTAN and PASIKA (2000).

The share of expenses for the economy gradually decreased as state support for the enterprises switched from the direct budget financing to the indirect support, as described in the previous section. The largest recipients of the budget financing were agricultural and coal mining sectors - the most depressed sectors in the economy. The level of state support itself was closely correlated with the poor performance of these two sectors (LUNINA and VINCENTZ, 1998; LEGEIDA, 2001; VON CRAMON-TAUBADEL and ZORYA, 2001).

Officially recorded budget expenditures were just a part of the actual expenditures. Implicit financing greatly reduced the transparency, distorted expectations, and encouraged corruption. The real economy was heavily subsidised through different state agencies, among which the most important are the Innovation Fund, the State Leasing Fund, and the State Material Reserve. Moreover, many enterprises 'enjoyed' additional financing from the reserve fund of the GOU. In 1999, for example, the number of socalled non-budget funds reached 7150 in Ukraine, which accumulated around UAH 10 bln (SULTAN and PASIKA, 2000). These funds are not shown in the budget and are controlled by different Ministries and Government agencies. In 2000, most of these funds were liquidated or subordinated, but some of them, such as the State Material Reserve, continue operating.

\subsubsection{Financing of the budget deficit}

Before 2000, Ukraine had the budget deficits ranging from 12\% of GDP in 1992 to $1.4 \%$ in 1999 (see table 6). "Accumulation of public debt through budget deficits means that some of today's disbursements by the government will have to be paid for in the future. This is justified if future returns cover both principle and interest payments" (THIESSEN and HofFMANN, 1999: 81). It was not the case in Ukraine. Before 1995, the budget deficit was fully financed by the National Bank of Ukraine (NBU) that had lead to the inflation and even to the hyperinflation at the beginning of transition (see table 8). ${ }^{17}$

\footnotetext{
${ }^{17}$ Inflation in Ukraine and its reasons will be considered in details in section 3.1.3.1.
} 
Table 8: Financing of the budget deficit in Ukraine, 1992-2001

\begin{tabular}{lccccc}
\hline & $\begin{array}{c}\text { Budget deficit, } \\
\text { UAH mln }\end{array}$ & $\begin{array}{c}\text { Budget deficit } \\
\text { as share to } \\
\text { GDP,\% }\end{array}$ & $\begin{array}{c}\text { Financing in \% of budget deficit } \\
\text { N }\end{array}$ & $\begin{array}{c}\text { NBU } \\
\text { External }\end{array}$ & Bonds \\
\hline \hline 1992 & -6.3 & -26.9 & 100.0 & 0 & 0 \\
1993 & -92.8 & -12.9 & 100.0 & 0 & 0 \\
1994 & -1139.7 & -16.9 & 100.0 & 0 & 0 \\
1995 & -4043.3 & -15.9 & 72.7 & 19.8 & 7.4 \\
1996 & -3617.0 & -10.7 & 40.2 & 22.8 & 37.0 \\
1997 & -6196.4 & -14.4 & 1.6 & 26.7 & 71.7 \\
1998 & -2018.3 & -5.1 & 0.8 & 68.0 & 31.2 \\
1999 & -1696.3 & -3.7 & 0.1 & 13.7 & 86.2 \\
2000 & 1891.8 & 3.1 & 0 & 0 & 0 \\
2001 & 571.6 & 0.8 & 0 & 0 & 0 \\
\hline
\end{tabular}

Source: UEPLAC (2002).

In September 1995, the GOU issued treasury bills for the first time. But the interest of the foreign investors in Ukrainian treasury bills became apparent in 1996 and steadily grew on. In general, the GOU has used four types of the securities: internal and external state saving bonds (T-Bills), eurobonds, and special bonds (HIID/CASE, 1998). In 1997, the treasury bills became the major source of the budget financing, apart from official external borrowings from the international organisations, mainly the IMF and the World Bank. The performance of the T-bill market was quite successful until end- 1997 . The desire to attract external resources, combined with Ukraine's low credit rating and competition with the Russian security markets, pushed the GOU to raise the real interest rates (ZORYA, 2001a). High yields attracted foreign investors. The effective annual rate of return was $143.3 \%$ in $1995,102.5 \%$ in 1996 , and $42.9 \%$ in 1997 . The demand for the T-bills was additionally encouraged when the NBU gave permission in November 1997 for banks to include investments in the T-bills in their mandatory reserves that later was one of the reason of the banking crisis in 1998 (HIID/CASE, 1998).

Over time, however, due to the increased loss of confidence in transition economies after the Mexico and Asia financial crises in 1994 and 1997, "this instrument became less attractive and investors started to pull out or were interested only in hedged operations" (IMF, 1999: 39). During the first half of 1998, the commercial banks and investors were reluctant to purchase treasury bills, and the GOU had to rely only on the NBU to finance the budget deficit and to service the public debts. In August-1998, due to the financial crises, Ukraine lost its access to the external markets while debts payments created a significant cash-flow problem for the budget.

Since 1995 along with resources from the security markets, the GOU has received the official credits and grants from the international organisations. In spring of 1995, the IMF has launched its stand-by program (IMF, 1997). Ukraine has also made intensive an use of the World Bank's structural adjustment lending, as well as the EU loans. In addition, Russia and Turkmenistan were important creditors, mainly due to the debts for 
the gas and oil supplies. After the financial crisis in the mid-1998, these official credits were the main sources of financing the budget deficit.

In general, the sources of the deficit financing in Ukraine were very volatile. The NBU financing was followed by 'hot' short-term loans and portfolio inflows which were very responsive to the short-tern changes in the interest rate and country's risk (DRABEK and GRIFFITH-JONES, 1998), and by official financing from the international organisations, which often meant the inability of the government to finance the deficit in other way (ROUBINI and WACHTEL, 1998) and which indicated that the situation could worsen in the future (DORNBUSCH, 2001). As a result, the foreign debt of Ukraine increased to an unsustainable level (THIESSEN and HOFFMANN, 1999; ZORYA, 2001a). Table 9 demonstrates the development of the foreign debts indicators, as well as the reserve adequacy.

Table 9: Foreign debts, debt service and reserve adequacy in Ukraine, 1994-2001

\begin{tabular}{lcccccccc}
\hline & $\mathbf{1 9 9 4}$ & $\mathbf{1 9 9 5}$ & $\mathbf{1 9 9 6}$ & $\mathbf{1 9 9 7}$ & $\mathbf{1 9 9 8}$ & $\mathbf{1 9 9 9}$ & $\mathbf{2 0 0 0}$ & $\mathbf{2 0 0 1}$ \\
\hline \hline Foreign debts at the end of year, \$ bln & 7.2 & 8.2 & 8.8 & 9.6 & 11.5 & 12.4 & 10.4 & 12.1 \\
Foreign debt as a share of GDP, \% & 18.9 & 22.2 & 19.8 & 19.1 & 27.4 & 39.4 & 32.6 & 32.2 \\
Foreign debt as percent of exports & 43.1 & 48.1 & 43.4 & 46.9 & 65.2 & 76.6 & 53.1 & 47.6 \\
Debt service ratio as percent of exports & 11.2 & 8.0 & 6.6 & 7.5 & 12.5 & 16.1 & 14.5 & 14.5 \\
\hline NBÜ gross international reserves, \$ bln & 0.65 & 1.05 & 1.96 & 2.34 & 0.76 & 1.05 & 1.40 & 3.10 \\
Reserves in weeks of imports & 1.9 & 3.2 & 4.9 & 5.6 & 2.2 & 3.7 & 4.2 & 10.2 \\
Reserves to M2, \% & 20.2 & 15.3 & 21.7 & 18.8 & 4.8 & 4.8 & 4.5 & 6.9 \\
Reserves as share of total foreign debts, \% & 9.1 & 12.8 & 22.7 & 24.4 & 6.6 & 8.4 & 13.5 & 38.8 \\
Reserves as share of short-term foreign & 44 & 77 & 143 & 143 & 32 & 35 & 59 & na \\
debts, \% & & & & & & & & \\
\hline
\end{tabular}

Source: $\quad$ UEPLAC (2002) and NBU (2002).

The foreign debts of Ukraine at the end of 2001 equalled to $\$ 12$ bln or $32.2 \%$ of GDP, greatly decreasing from its peak of 39.4\% of GDP in 1999. Together with the internal state debts, the share of the total debts in GDP equalled to 36\% (or $\$ 14$ bln) in 2001 (MINFIN, 2002). To assess the reserve adequacy, three ratios from table 9 will be considered: (a) reserves to import coverage, (b) reserves to $\mathrm{M} 2$, and (c) reserves to foreign debts of different maturity. The coverage of these indicators is necessary "as the crude rule of thumb that reserves have to equal at least three months of imports and it would be enough to maintain the financial stability has lost much of its relevance as openness and external vulnerability are no longer merely defined in terms of trade shocks" (DE BEAUFORT WIJHOLDS and KAPTEYN, 2001: 9). It is necessary to take into account an increased importance of capital flows and to relate the size of reserves to a country's short-term external debt.

First of all, the international reserves in Ukraine have never exceeded even a two month import coverage, indicating constantly low provision of reserves in the country. Secondly, the reserves to M2 ratio was relatively low in Ukraine compared with suggested by the IMF " $10-20 \%$ for countries with a managed float or fixed exchange- 
rate-regime and 5-10\% for independently floating regime" (DE BEAUFORT WIJHOLDS and KAPTEYN, 2001: 15). Being an indicator of the potential for capital flight, the reserves to M2 ratio determines the certain fraction of the broad domestic money supply that could be used to purchase foreign currency (i.e. the potential demand for foreign assets from domestic sources). In the case of Ukraine, the ratio of $7 \%$ in 2001 under the managed float exchange-rate-regime, for instance, was relatively low for financial stability. Moreover, this rate should be also adjusted for high country's risk. The third indicator of the reserve adequacy is the country's liquidity or the rate of reserves to foreign debts. In this respect the long-term and short-term debts should be distinguished: in the former case, the insolvency means that the borrower lacks the net worth needed to repay debts out of future earnings, while in the latter the illiquidity means that the borrower lacks the cash needed to repay current debts even though he might be perfectly able to honour his debts in the long run (BUCHS, 1999). Looking at table 9, Ukraine was neither solvent nor liquid during the observed period. Only in 1996 and 1997, the liquidity ratio was relatively high, but after the years of the debt accumulation Ukraine's reserves could cover only $50 \%$ of its current debts in 2001 despite restructuring of the foreign debts in 2000 and 2001 (ZORYA, 2001a).

Despite the low liquidity of Ukraine's economy, in 2000 and 2001 the situation substantially improved. Balanced budgets greatly contributed to the recent economic growth. And if these developments become sustainable, the situation with the country's liquidity and growth would surely continue to improve.

\subsubsection{Monetary and exchange rate policies in Ukraine}

Similarly to the fiscal stabilisation, the financial stabilisation has also been a very important goal of the GOU throughout the last decade. In the Soviet Union the prices were significantly distorted through the subsidies and state administrative controls. Nonrealistic exchange rate had wrongly, if at all, translated the world market prices into the domestic ones. Moreover, "during the Soviet time the money overhang had been built, i.e. the money supply exceeded the money demand without the creation of the inflation" (GERLOFF, 2001: 45). The first step of the financial stabilisation for Ukraine, therefore, was designed to be the correction of initially distorted prices and price ratios, as well as the achievement of money market equilibrium. In spite of the predicted rise of inflation, these painful corrections were necessary to allow formation of non-distorted prices at which the market agents could make their decisions on production and saving/investment in the absence of the centrally-planning system. In addition, the creation of the exchange market was needed to ensure the undistorted transfer of price signals from the world markets and to maintain the external balance of Ukraine's economy.

\subsubsection{Inflation and development of the monetary indicators}

Predictions of high inflation in Ukraine have been fully confirmed. During 19911995, Ukraine experienced the hyperinflation of around $40 \%$ per month. The peak of the hyperinflation was reached in 1993 with the level of $10250 \%$ per annum; in 1995 it decreased to a still high level of $280 \%$ (NBU, 2002b). The main reasons of the hyperinflation were already mentioned in section 3.1 - the weak fiscal discipline and NBU's printing off money to finance the huge fiscal deficit. Besides, real money demand in the early transition period appeared to be very low. According to the IMF (1997: 31), 
"before 1994, the real money demand exceeded its long-term relationship with the growth of the real industrial output, pointing out the administrative control over prices. With price liberalisation in late 1994, real money demand collapsed, falling below its long-term relationship. Only in 1996, real demand started to recover, though only gradually". So, the actual inflation in early transition was only partially attributed to the price corrections mentioned above. Existence of the administrative control over prices and partial price liberalisation measures (e.g. on exchange market) did not allow the creation of the basis for future economic growth (see figures 18 and 19).

In 1996, Ukraine achieved sustained price stability for the first time since declaring Independence. Inflation dropped to an average monthly rate of $2.8 \%$ (see figure 20). Inflation rate increased again in the aftermath of the financial crisis in 1998, but in 2001 it dropped to relatively low level of $6.1 \%$ per annum. Three key factors underlie the stabilisation in 1996: firstly, the rapid development of the treasure-bill market allowed the GOU to give up crediting the budget deficit through the NBU financing; secondly, the NBU improved the general co-ordination of monetary and exchange rate policies; and thirdly, Ukrainian national currency, hryvnia, was introduced in August 1996 which strengthened the population's confidence in the domestic currency. Throughout 1996-97, the NBU built up its international reserves and continued to address the changes in the banking sector (see figure 21).

Figure 20: Prices and money supply in Ukraine, 1996-2001 ${ }^{18}$

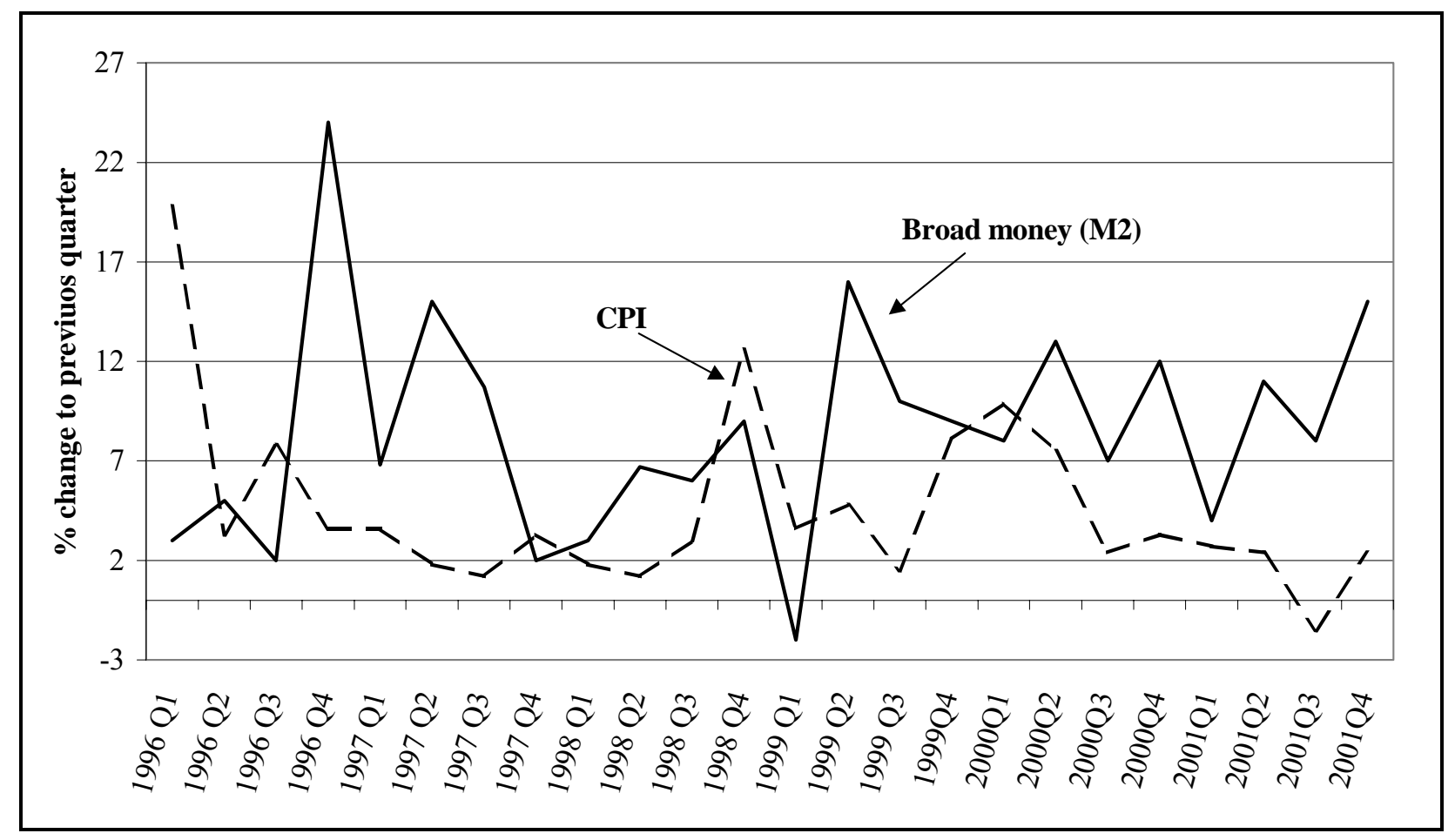

Source: $\quad$ NBU (2002b).

\footnotetext{
18 The monetary and price developments are shown beginning from 1996 in order not to distort the presentation of the figures to years with lower inflation levels.
} 
Figure 21: Liquid international reserves in Ukraine, 1996-2001, (\$ mln)

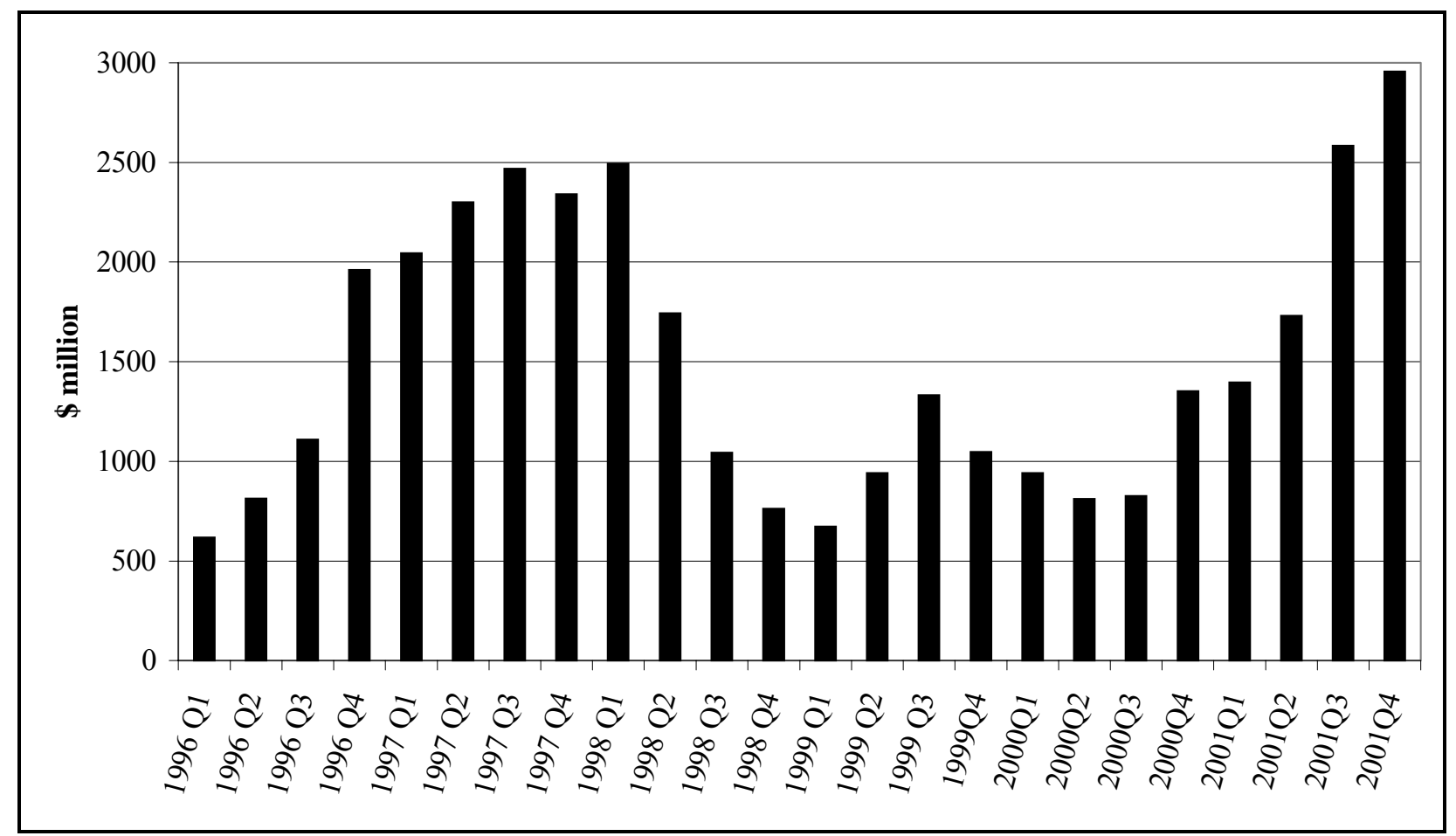

Source: $\quad$ NBU (2002b).

Moreover, tight monetary policy neutralised previous major source of inflation. ${ }^{19}$ But since the fiscal and structural policies did not support relatively successive monetary policy, this financial stabilisation was short-lived. The economy's degree of monetisation (M2 relative to GDP) in 1997 increased slightly to $13.5 \%$ compared with $10.4 \%$ in 1995 . "This represented extreme under-monetisation, or to put it another way, very high velocity of circulation of the hryvnia, implying that the currency was accepted as a medium of exchange but not a store-of-value asset" (MOELLERS and SIEDENBERG, 1999: 64).

At the end of 1997, in the aftermath of the Asian financial crisis and due to the weak progress in the overall economic reforms, the foreign capital started to flow out from Ukraine's treasury-bill market (IMF, 1999). This put financial policy and external reserves under considerable pressure. With little or no access to international or domestic creditors, the GOU relied heavily on borrowing from the NBU to finance the deficit and service public debts. The decision to support the hryvnia at the time of substantial downward pressures on the exchange rate required heavy NBU intervention into the foreign exchange markets. In September 1998, the NBU stopped selling foreign exchange to the market and introduced a number of administrative measures to control the foreign exchange market.

In 1999 and 2000, the annual inflation rate equalled to 19.2 and $25.8 \%$. The inflation in these years has been mainly driven by an increase of the food prices and

${ }^{19}$ The excessive money supply over domestic money demand was this major inflation source. According to VoLOSOVYCH (2002), the $1 \%$ change of M2 after eight months results in $0.34 \%$ change of the inflation in Ukraine. 
housing and public utility prices. Moreover, Ukraine continued to experience capital outflow and with low international reserves it could not dampen the currency devaluation (see section 3.2.3). Finally, in 2001 the annual inflation was only $6.1 \%$, achieved through an increased real money demand in Ukrainian economy encouraged by the domestic economic reforms and the fall in the world oil prices (VAKHNENKO, 2001).

\subsubsection{Interest rates}

The developments of interest rates in Ukraine are shown in figures 22 and 23. In years of the hyperinflation, in spite of the positive nominal interest rates, real interest rates were negative until 1996Q1. This was a strong signal for the firms to borrow, but not necessarily to invest into production, especially because of significant uncertainty. In 1993 , for example, when inflation reached up to $10000 \%$, state credits were granted to the agricultural enterprises at $20 \%$ rates of interest, and thus, represented gifts to those who could quickly convert them into currency or tradable commodities (ASLUND, 1999). Since not all economic actors had an equal access to the capital, the rent-seeking behaviour grew. In such a situation, the interest rates did not play their proper role of allocating capital and inducing the economic growth.

Although at the end of 1996 and in 1997 real interest rates in Ukraine remained high, nominal interest rates moved down, especially during the first three quarters of 1997, when inflation sharply declined (see figure 23).

Figure 22: Interest rates in Ukraine, 1993-1996, (in \% per quarter)

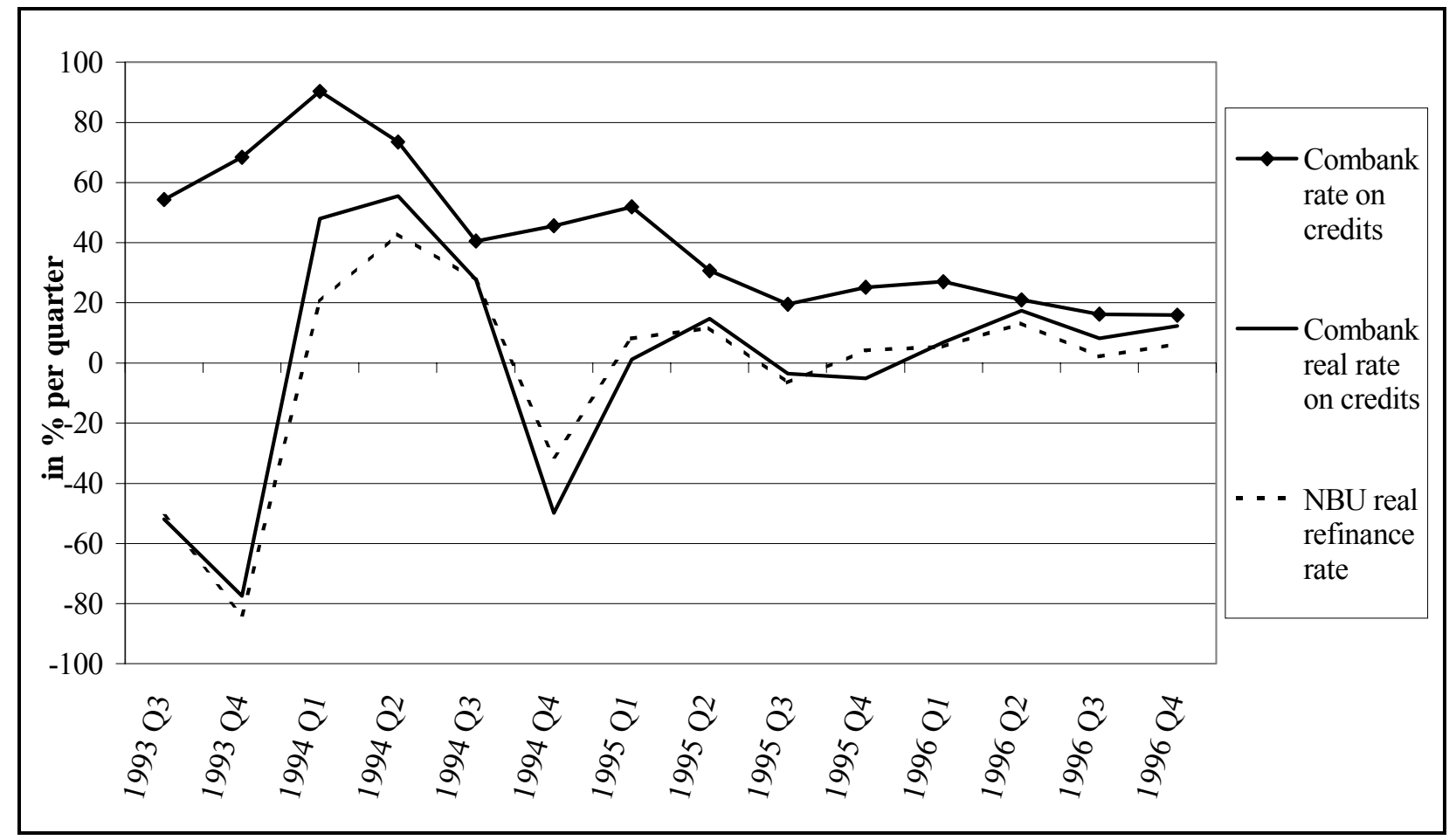

Source: $\quad$ NBU (2002b). 
Figure 23: Interest rates in Ukraine, 1997-2001, (in \% per quarter)

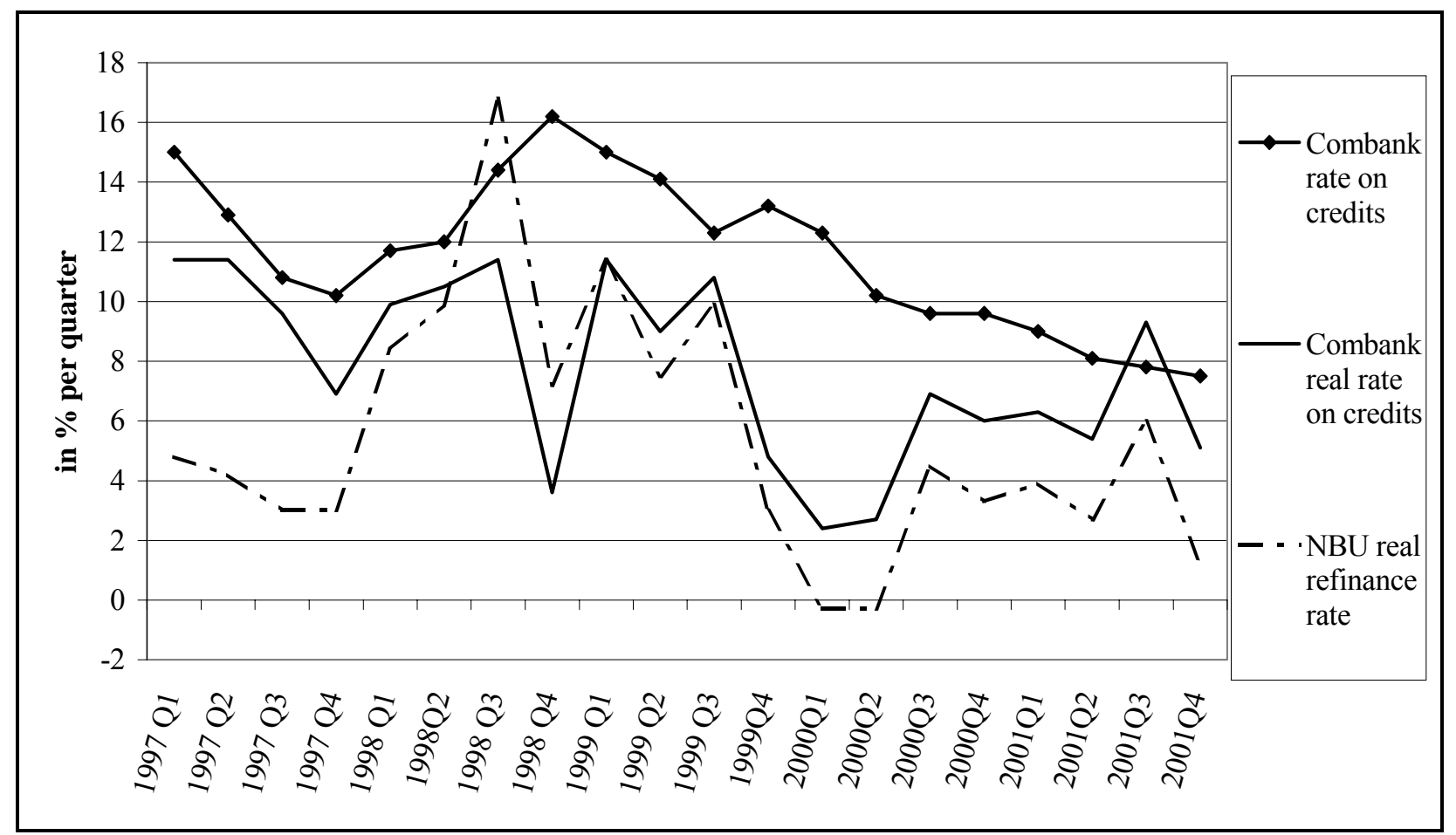

Source: $\quad$ NBU (2002b).

The decline of the average commercial bank lending rate, which was legally tied to the NBU refinance rate until September 1996, mirrored the fall of the statutory refinance rate during this period (IMF, 1997). But this fall in the commercial bank lending rate had relatively little significance, because of the cautious lending policies of commercial banks and investments into the lucrative treasury-bills that crowded out loans for the real economy.

When foreign investors started to leave the Ukrainian treasury-bill market, the NBU sharply raised the refinance rate to attract new investments into the state security market and to increase domestic savings. In this period it became obvious that the NBU had lost its leadership in establishing short-term interest rates. Changes in the refinance rate did not significantly influence either volumes of commercial bank refinancing or their interest rates. "Other factors, including generally low efficiency of the Ukrainian financial system and riskiness of business environment, seemed to determine interest rate policy of commercial banks, countervailing the NBU refinancing rate policy" (IER, 2002: 53). This situation did not change significantly even in 2001.

After the financial crisis in the mid-1998, the real interest rates followed the upand-down trend. Interest rates have started to gradually decline for the first time since 1999. Against the background of lower inflation levels, real interest rates in 2000-2001 reached their lowest level since 1995. At the end of 2001, the annual commercial bank real lending rate equalled $26.4 \%$ in average (UEPLAC, 2002), which is still high even compared with the CEE transition economies. In 2000, in Hungary, for example, a commercial bank real lending interest rate equalled $2.6 \%$ per annum, in Czech Republic $3.1 \%$, in Slovakia $-2.5 \%$, and in Poland - 9.1\% (IFS, 2002).

The most important reasons for this situation are the high operating costs of many Ukrainian commercial banks, high risks of 'bad' loans, slow structural reforms, and 
political risks. First of all, the efficiency of the banking system, measured by the difference between the credit and deposit interest rates, is very low in Ukraine. During 1994-1997, this difference equalled to around 30\%, and although it declined in 2001 to $21 \%$, it remains high. "This high spread covers the bank operating costs only" (see STRIEWE et al., 2001a: 67). Poor management of the credit portfolio, manipulations of accounting system, and disbalance between credits and reserves conditions, worsen efficiency of many Ukrainian banks (KIREEV, 2002). Moreover, low trust of the population to the banking system further increases (nominal) deposit interest rates, which in 2001 equalled $20-24 \%$ per annum.

Secondly, the risk of 'bad' loans is still substantial. Commercial banks hesitate to expand their credit activities because of the absence of appropriate collateral and risk insurance mechanisms, and because of the bad experience of the previous years when large amounts of bad loans were accumulated (CONTEXT, 2002). The risk of bad loans closely correlates to the political risks (i.e. third reason of high interest rates). Commercial banks had bad experience with treasury-bill market and political pressure lend to certain enterprises or even sectors (for example, agriculture). In 1998, for example, the NBU restructured most of its debts to private banks without their approval. Moreover, Ukraine had a very low international credit rating, as a warning signal not only for the international creditors, but for domestic ones as well.

Finally, the demand for credits remains high even with steep interest rates. Slow structural reforms allow some firms to get privileged access to modern technologies which enable them to pay high interest rates (PrOSOROV, 2002). In this situation, banks do not want to lose income, since clients agree to pay such a high interest (around $73 \%$ of all credits are disbursed by five biggest banks, which allows them to control the interest rates (BUGRIY, 2002)). These four reasons determine high interest rates in Ukraine.

Without these inefficiencies and risks and with free capital mobility, interest rates in Ukraine would have been much lower than their actual levels. According to the interest rate parity theory (see BOFINGER, 2001: 392), interest rates in Ukraine can be defined in the following way:

$$
i=i^{*}+\Delta e / e
$$

where $i$ is the domestic real interest rate, $i^{*}$ is the foreign interest rate, and $\Delta e / e$ is the expected real currency depreciation. The interest rate parity theory states that in the long run the domestic interest rates in Ukraine should equalise with the world rate of interest. If this is true, the actual real interest rate in Ukraine could have been much lower (see table 10). 
Table 10: Actual and implied real interest rates in Ukraine, 1996-2001, (annual average in percent)

\begin{tabular}{lrrrrrr}
\hline & $\mathbf{1 9 9 6}$ & $\mathbf{1 9 9 7}$ & $\mathbf{1 9 9 8}$ & $\mathbf{1 9 9 9}$ & $\mathbf{2 0 0 0}$ & $\mathbf{2 0 0 1}$ \\
\hline \hline Actual NBU real refinancing interest rate & 62.04 & 24.60 & 60.96 & 50.04 & 30.60 & 19.80 \\
$\begin{array}{l}\text { Average real interest rates in Germany for } \\
\text { local bonds }\end{array}$ & 6.22 & 5.66 & 4.57 & 4.51 & 5.27 & 4.81 \\
$\begin{array}{l}\text { RER depreciation (appreciation) in Ukraine, } \\
+ \text { (-), UAH/ }\end{array}$ & -21.42 & -0.23 & 30.02 & 1.49 & -13.76 & -0.77 \\
\begin{tabular}{l} 
Implied real interest rate in Ukraine \\
\hline
\end{tabular} & -15.20 & 5.43 & 34.59 & 6.00 & -8.49 & 4.04 \\
\hline
\end{tabular}

Source: $\quad$ Own presentation based on UEPLAC (2002) and DBR (2002).

In 1996 and 1997, the real interest rates in Ukraine were substantially raised to attract the short-term capital into the state security market. Despite high interest rates in those years, the share of the portfolio and short-term investments equalled roughly $10 \%$ of the capital account (NBU, 2001). In 2001, when the actual interest rate was four times higher than the implied one, portfolio investments outflow accelerated to the sum of $\$ 866 \mathrm{mln}$. The weak response of the foreign capital to high interest rates in Ukraine can be explained by high risks associated with the business and investment activities in the country (see also IER, 2002: 52-53). These risks substantially limited the foreign capital inflows in Ukraine and impeded economic transformation.

The level of the commercial credits in the Ukrainian economy remains low, though it is gradually increasing. In 1993, commercial banks have directed UAH $406 \mathrm{mln}$ of the credits to the economy that equalled to $27 \%$ of the GDP (or $30.6 \%$ of all payables). Since then the nominal credit disbursement increased, but its share of GDP first decreased to $7 \%$ in 1996, and then started gradually to increase, reaching $13 \%$ in 2001 (NBU, 2002b). The share of the credits in total payables increased from $2.9 \%$ in 1999 to $6.9 \%$ in 2001 (UEPLAC, 2002). The further reforms in the real economy and banking sector are urgently needed to attract more credits to the economy and consequently, to ensure the sustainable economic growth.

\subsubsection{Exchange rates in Ukraine}

\section{Nominal exchange rate regimes in Ukraine}

There was little liberalisation of the currency exchange market in Ukraine between 1991 and 1994. From the end of 1994 and till mid-April of 1997, Ukraine had an exchange rate regime close to a float since structural weaknesses did not allow stabilisation of the value of the currency. The GOU believed that a fixed-exchange-rateregime would strengthen confidence in the government's economic policy. However, at the beginning of this period, the NBU had extremely low international reserves to give up a float (see figure 14). Moreover, the uncertainty of exchange rate fluctuations due to unpredictable public behaviour after introduction of the hryvnia explained rather careful and conservative behaviour by the monetary authority (DEKHTIARCHUK, 1999). The subsequent boom in portfolio investments has replenished the currency reserves, and with the achievement of the sustained price stability, Ukraine switched to the fix-exchangerate-regime. In April 1997, the government unofficially announced a narrow band of UAH 1.7-1.9 per U.S. dollar, which was formalised in September (IMF, 1999). After 
that, several wider bands have been set, and since January 2000, the government announced that it would follow a floating exchange rate policy (see table 11).

The first three quarters of 1997 were characterised by significant capital inflows and persistent upward pressures on the hryvnia. The capital inflows were associated, to a large extent, with purchases of treasury bills by non-residents, as well as stability in international financial markets, the liberalisation of capital account restrictions, and unrestricted access of foreign residents to the treasury-bill market. The NBU significantly replenished its international reserves during this period.

Table 11: Currency corridor policies in Ukraine, 1997-1999

\begin{tabular}{lcccc}
\hline $\begin{array}{c}\text { Date of band } \\
\text { announcement }\end{array}$ & $\begin{array}{c}\text { Range } \\
\text { (UAH per US\$) }\end{array}$ & $\begin{array}{c}\text { Announced } \\
\text { time limit }\end{array}$ & $\begin{array}{c}\text { Devaluation, } \\
\%\end{array}$ & $\begin{array}{c}\text { Compliance with } \\
\text { established limits }\end{array}$ \\
\hline \hline April 1997 & $1.7-1.9$ & End of 1997 & 12 & Yes \\
October 31, 1997 & $1.75-1.95$ & $\begin{array}{c}\text { First half of } \\
1998\end{array}$ & 11 & Till January 19, 1998 \\
January 19, 1998 & $1.8-2.25$ & End of 1998 & 25 & Till September 3, \\
September 5, 1998 & $2.5-3.5$ & Not announced & 40 & Till February 8, 1999 \\
February 9, 1999 & $3.4-4.6$ & End of 1999 & 35 & Yes \\
\hline
\end{tabular}

Source: DEKHTIARCHUK (1999).

The financial crisis that hit many Asian economies during August and September 1997 disrupted the favourable external environment that had facilitated Ukraine's progress toward financial stabilisation, while weak support from the real economy had further worsen the confidence in the exchange rate band. Till mid-1998, the GOU twice changed upward the peg bands, and it has still believed that the existence of clear currency policy objectives for the next year would renew the confidence of investors and reduce pressure on the currency market. Unfortunately, these bands turned out to be unrealistic (DEKHTIARCHUK, 1999).

In September 1998, the NBU has stopped selling foreign exchange to the market, introduced a number of administrative measures to control the foreign exchange market, and moved the exchange rate band to UAH 2.5-3.5 per \$1. This band lasted until February 1999, thanks only to the strict regulation of the currency market. The NBU established limits on transactions for freely convertible currency, including a reduction of the margin between the currency sales and purchase rates; mandatory sale of $75 \%$ of currency revenues (subsequently reduced to 50\%) and shutting down the Inter-bank currency market. The most negative effect of these innovations was the deterioration of public confidence in NBU management, while earlier it had enjoyed the greatest measure of credibility compared to other state institutions.

After one more currency band of UAH 3.4-4.6 per \$1 in 1999, in 2000 the GOU and the NBU issued a joint statement on switching to a managed floating exchange rate regime. This managed float still remains in operation. Developments of the NER along with the RER in Ukraine will be discussed further. 


\section{Real exchange rates in Ukraine}

The RER is an important issue in the international economics. It is at the heart of the current discussions on financial crises and economic growth-encouraging policy. It is widely accepted that a bad balance sheet (or illiquidity) and overvalued real exchange rate are the main reasons of the 'modern financial crises' (DORNBUSCH, 2001). The RER may be defined in different ways. According to HALPERN (1996), there are five commonly used indicators of the RER. The first is computed on the basis of industrial wholesale prices. The second is computed by the consumer price indices. The third is the ratio of the price indices of traded to non-traded sector proxied by the ratio of producer to consumer price indices (see EDWARDS, 1989). The fourth is the RER based on unit labour costs, and finally the fifth indicator proposed by LIPSCHITZ and MCDONALD (1992) relates the total nominal relative wage costs to the relative production at current prices.

Although it might be important for some reasons to analyse in details all the indicators, in this section only third and fifth indicators will be considered to make a short analysis of the development of the RERs. These two indicators are the most useful in reaching the objectives of this thesis. The development of the RERs (third indicator) in Ukraine is presented in figure 24.

The bilateral RERs are defined as the wholesale (or producer) price indices of foreign trade partners multiplied by correspondent NER and divided by Ukrainian consumer price index (CPI). An increase (decrease) of the RERs means the RER depreciation (appreciation). For simplicity, only bilateral exchange rates against U.S. dollars, Euro, and Russian Rouble with equal shares (1/3 to each currency) are taken into account (see reasons of this approach in Mankovska et al., 2002).

Figure 24: The development of real exchange rates in Ukraine, 1994-2001, (PPI/CPI based)

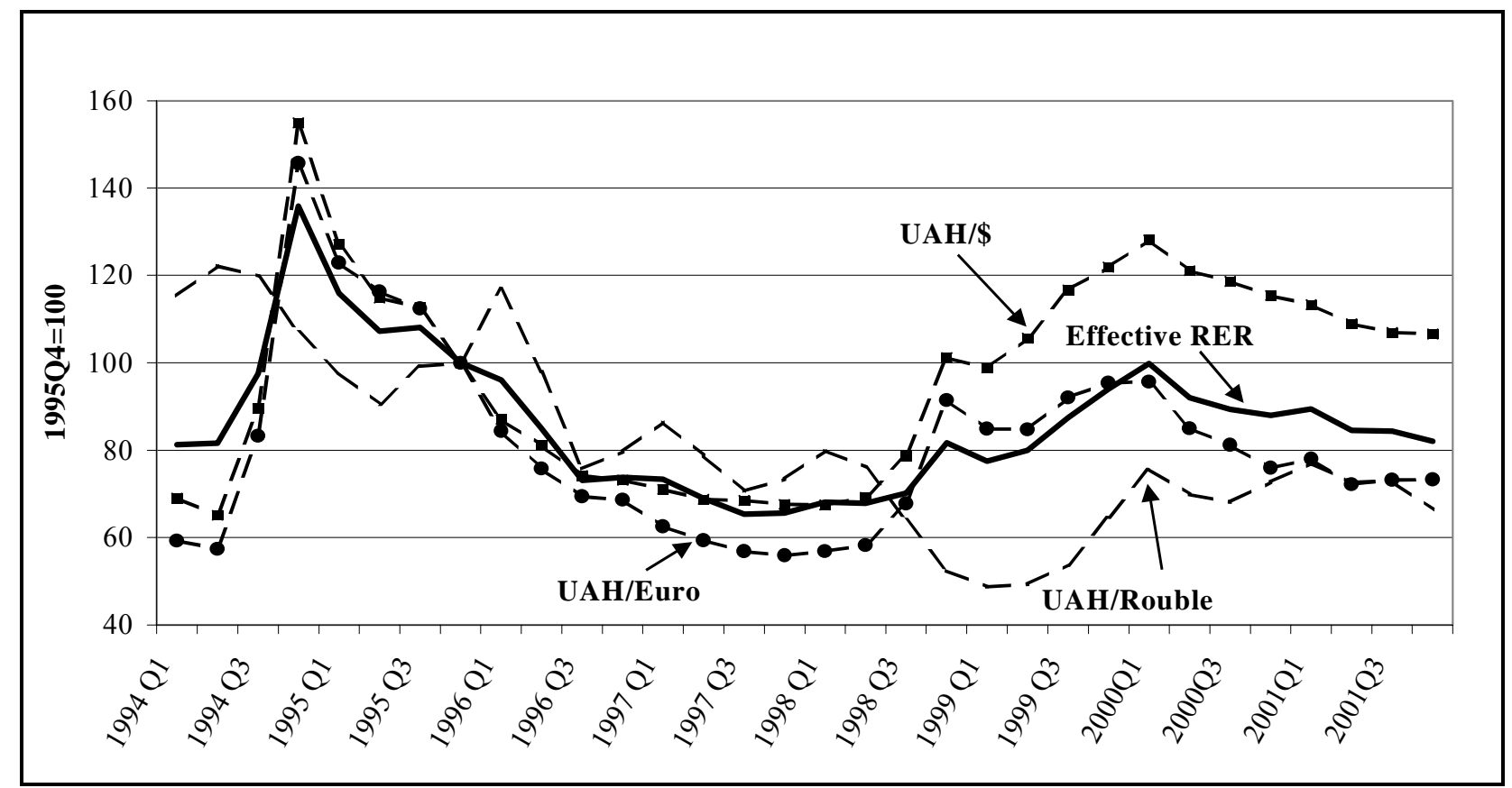

Source: Own presentation based on UEPLAC (2002) and OECD (2001a). 
The development of the effective RER in Ukraine can be divided into four distinctive phases:

1. During 1991-1994, an initial sharp depreciation.

2. During 1995-mid-1998, a real appreciation.

3. Financial crisis and a consequent strong real depreciation, and

4. Exchange rate stabilisation and since 2000, a gradual appreciation.

There is almost no disagreement concerning the first phase of the effective RER development. Similarly to other CEE transition economies, the initial depreciation in Ukraine was associated with the end of the command economy, when the system of previously prevailing multiply exchange rates was replaced by a single rate set in a reasonable free market. HALPERN and WYPLOSZ (1996: 5) proposed the following explanations of such a development: "The long-repressed demand for foreign assets (previously reflected in the black market premium) faced a negligible supply. Since the available net stock of foreign assets could not increase simultaneously in volume, market equilibrium required a price increase. The undervalued exchange rate allowed for the net acquisition of foreign assets through current account surpluses. Over time, correction from undervaluation led to the closing of the current surplus as the domestic stock of foreign assets rises to meet demand at the equilibrium exchange rate. Moreover, the freeing of prices in the presence of monetary overhang was met by a sudden burst of inflation. It also increased demand for foreign assets, in this case foreign cash. This disequilibrium situation resulted in undervaluation."

An agreement concerning the second phase of the effective RER development in Ukraine is straightforwardly reached. During this phase, the effective RER strongly appreciated (mainly through the appreciation of $\mathrm{UAH} / \$$ and $\mathrm{UAH} / €$ exchange rates). During 1995Q1-1998Q2, the effective RER appreciated by 71\%. A real appreciation took place mainly due to high domestic inflation since the effective NER depreciated by $30 \%$ (see figure 25). ${ }^{20}$

Concerning transition economies, there are two views on the sustainability of the RER appreciation. From one point of view (misalignment view), the RER appreciation in the transition economies has caused a loss of competitiveness that worsens the current account (BRADA, 1998; LINNE, 1998; ROUBINI and WACHTEL, 1998; BEGG and WyPLOSZ, 1999). From the other point of view (fundamental view), it represents real sector fundamentals that alter the balance of savings and investment. In latter case, any RER appreciation is an adjustment, or return to, a long-run equilibrium RER (HALPERN and WYPLOSZ, 1996; GRAFE and WYPLOSZ, 1997; KRAJNYAK and ZETTELMEYER, 1997).

${ }^{20}$ The depreciation (appreciation) is calculated as $\frac{R E R_{t+1}-R E R_{t}}{R E R_{t+1}}$. 
Figure 25: Effective nominal and real exchange rates in Ukraine, 1994-2001

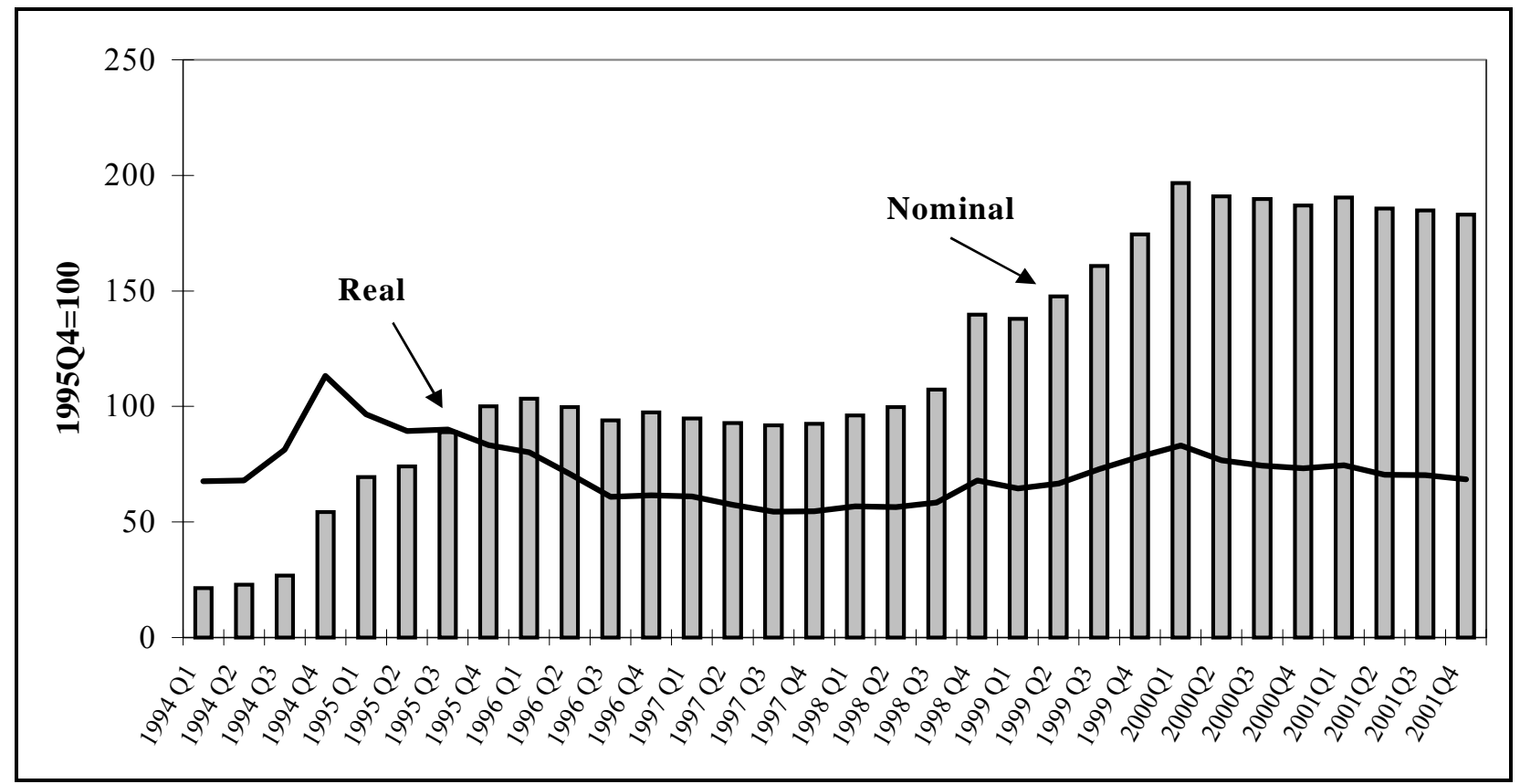

Source: $\quad$ Own presentation based on UEPLAC (2002) and OECD (2001a).

The fundamentalists explain the RER appreciation as a 'right' track of economic recovery. The transition from a centralised to a market economy needs significant adjustments which should lead to the RER appreciation. HALPERN and WYPLOSZ (1996) argue that the RER appreciation in transition economies gradually corrected initial undervaluation and is a result of the transformation process. Through 'positive' changes in the productivity growth (Balassa-Samuelson effect), improved quality of products, growth of the wages in initially depressed non-traded sector, and there are capital inflows in the form of the foreign direct investments. The appreciation, therefore, corrected initial RER undervaluation and adjusted the RER to positive structural changes in the economy. According to KRAJNYAK and ZETTELMEYER (1997), the RER in Ukraine expressed in the actual dollar wage in 1996 was still 51\% lower than its equilibrium level, pointing to a huge scope for further RER appreciation.

The representatives of the misalignment view argue that the RER appreciation in the transition economies can be a consequence of the choice of an inappropriate/unsustainable exchange rate regime and ensuring the capital inflows; therefore, it represents a loss of real competitiveness. Early in transition, disinflation was a key policy concern in most transition economies. Nominal anchors were seen as commitments to guide central banks and offer them some protection against pressure for easy money. "Such pressure was intense, from cash-strapped governments, from unprofitable firms accustomed to automatic state financing, and from various actors who did not believe that inflation is a monetary phenomena" (BEGG and WYPLOSZ, 1999: 3). And if the fixed exchange rate regime was accompanied by slow structural reforms, persistent fiscal imbalances, and protectionist commercial policy, the RER probably had been misaligned (overvalued in comparison to its equilibrium path) and country's competitiveness was seriously hurt. Moreover, an increase of the gap between domestic and world interest rates in order to attract foreign investors accelerated the RER 
appreciation, meaning the loss of the competitiveness in those cases where future productivity would not improve from the use of inflowing capital.

I believe that the RER appreciation in Ukraine developed under the misalignment scenario. This statement for Ukraine is explicitly and implicitly supported in MOELLERS and SiEDENBERG (1999), HIID/CASE (1998), DEKHTIARCHUK (1999), and ZORYA (2001a). The 1998's financial crisis provided evidence in favour of this hypothesis. In spite of the belief that the fixed-nominal-exchange-rate-regime calls for better macroeconomic policy, in the case of Ukraine, this regime was accompanied by the 'sound' macroeconomic policy in a way comparable to that of many other emerging economies which tried to improve the government's behaviour in this way (see EDWARDS and SAVASTANO, 1999; EDWARDS, 2000). Probable RER misalignment before the financial crisis is supported by figure 26. In the years of the effective RER appreciation (1996-1998), the trade balance was negative, and the magnitude of the appreciation seemed to shape the magnitude of the trade deficit. After the sharp effective RER depreciation, the trade balance showed a surplus, proving that the previous real appreciation hurt Ukraine's competitiveness. ${ }^{21}$

The RER in Ukraine performed under the well-known scenario of the unsustainable appreciation described by DORNBUSCH (1996) for the Mexican crisis in 1994: "Exchange rate-based stabilization goes through three phases: The first one is very useful ... Exchange rate stabilization helps bring under way a stabilization... In the second phase increasing real appreciation becomes apparent, it is increasingly recognized, but it is inconvenient to do something... Finally, in the third phase, it is too late to do something. Real appreciation has come to a point where a major devaluation is necessary. But the politics will not allow that. Some more times is spent in denial and then sometime - enough bad news pile up to cause the crash".

The crash of Ukraine's RER was significant indeed and there is a suspicion that the RER had even overshot its sustainable level. Over 1998Q3-2000Q1 (third period), the ERER depreciated by over 30\% (while the effective NER depreciated by $45 \%$ ).

During the forth period, the effective RER gradually appreciated driven by the real appreciation of UAH/\$ and UAH/€ exchange rates. The RER with Russian Rouble instead started to depreciate, dampening the total rate of appreciation. During 2000Q22001Q4, the effective RER has appreciated by 9\% due to the appreciation of the RER of $\mathrm{UAH} / \$$ by $13 \%, \mathrm{UAH} / €$ by $16 \%$, and the depreciation of the RER of UAH/Rouble by 4\%. The sustainability of such an appreciation as well as the development of the RER during the whole observed period will be empirically studied in section 4.1.1.5. In short, in Ukraine the ERER appreciation in this period could be sustainable due to the increase of the productivity and balancing of the budget, or it could be just short-term appreciation due to the state debt restructuring that dampened the capital outflow. Moreover, the RER appreciation could be just the correction of the previous RER overshooting.

\footnotetext{
${ }^{21}$ MANKOVSKA et al. (2002) found out that the trade balance in Ukraine reacted to the changes of the effective RER as a J-curve - in the first quarter after the effective RER depreciation, the trade balance worsens, but already in the second quarter the balance starts improving.
} 
Figure 26: Impact of the effective RER on trade balance in Ukraine, 1996-2001

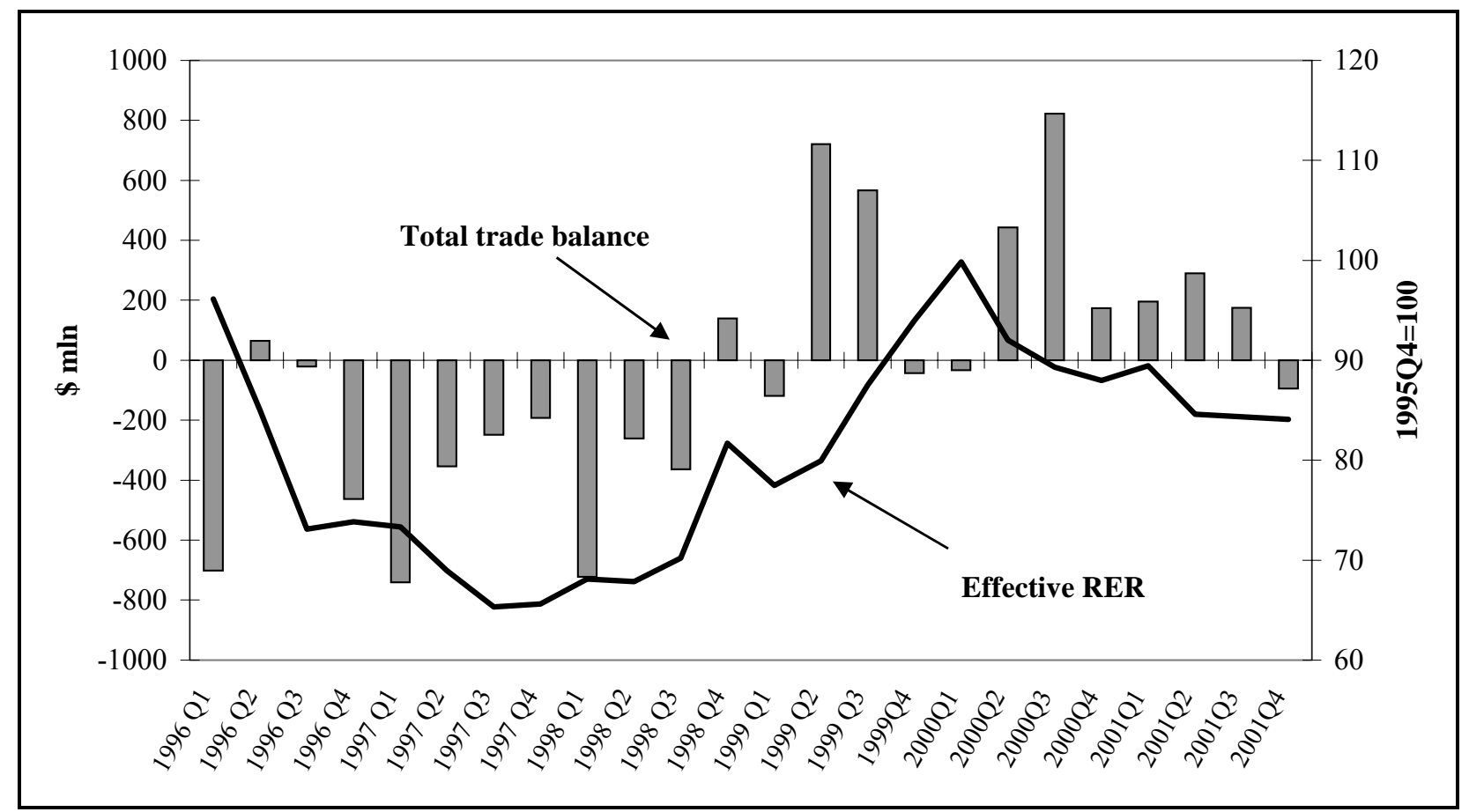

Source: $\quad$ Own presentation based on UEPLAC (2002).

Another RER indicator in Ukraine is the ratio of the labour productivity to unit labour costs (ULC). The productivity rate is calculated as the ratio of gross value-added per worker employed, while the unit labour costs are the average labour costs per nominal GDP. This indicator compares the total nominal relative wage costs with relative production at current prices and it shows the combined effects of productivity and labour costs on the industry's competition. If the RER is increasing, labour productivity increases faster than the unit labour costs, which shows increased competitiveness in a sector or the economy. In this case one may state that the RER depreciates and visa versa. The development of the RER for Ukrainian economy as a whole is demonstrated in figure 27. Until 1998, the RER appreciated, i.e. the ULC grew quicker than the labour productivity. In this period, a sharp increase of the ULC "rendered a large part of the existing capital stock unprofitable and led it to being scrapped, resulting in a large output decline" (BERENGAUT et al., 2002: 32). A RER appreciation over 1993-1998 is another proof of unsustainability of the effective RER in the 'second phase' of its development (see discussions above). During 1998-2000, the RER depreciated as "subsequent decline in real labour costs brought part of the mothballed capacity back into production, resulting in a strong increase of industrial output" (BERENGAUT et al., 2002: 32). In 2001, the RER slightly appreciated, as the average ULC growth exceeded labour productivity growth in the whole economy. 
Figure 27: Ratio of labour productivity to ULC in Ukraine, 1993-2001

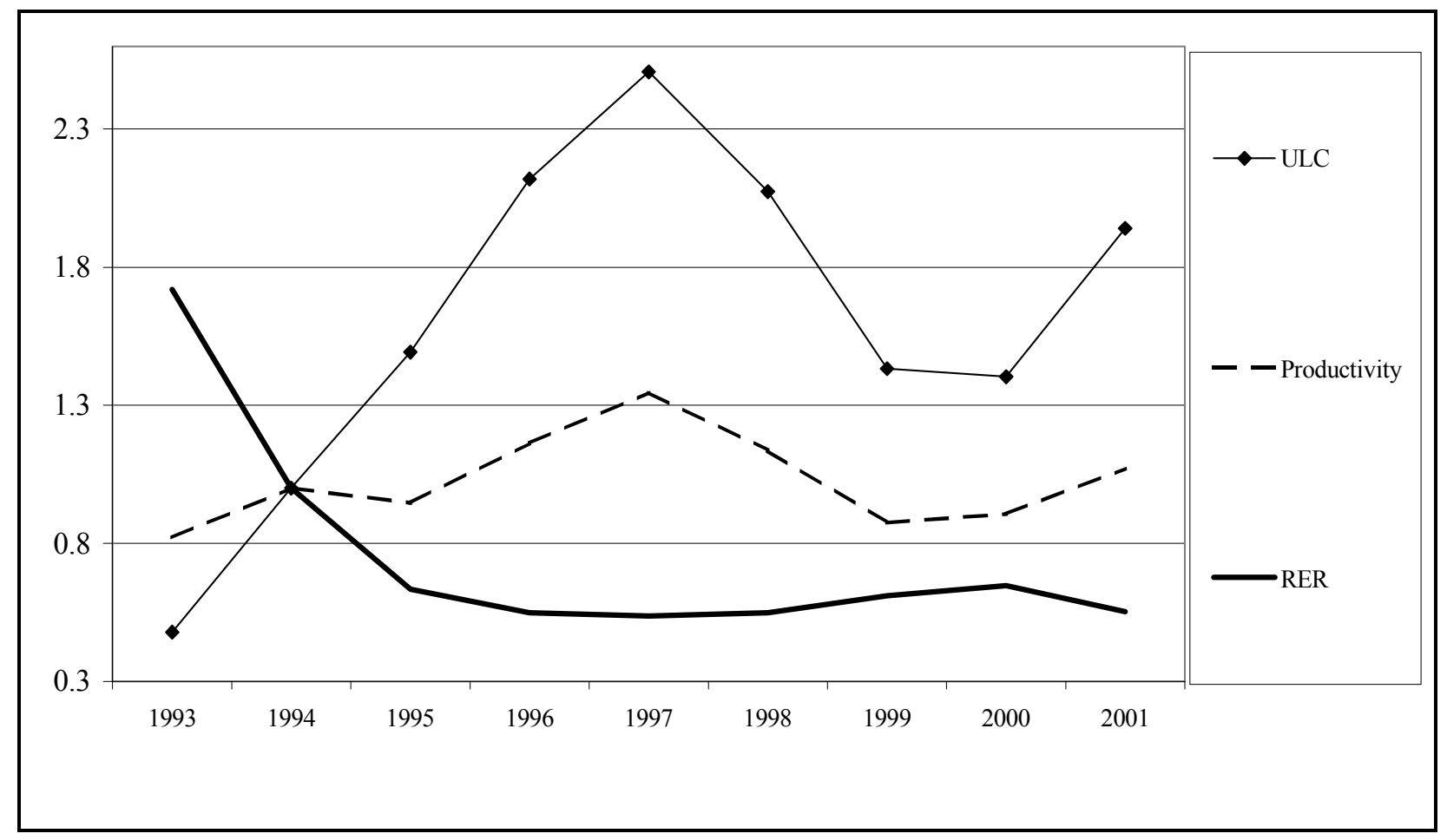

Source: $\quad$ Own presentation based on UEPLAC (2002) and BERENGAUT et al. (2002).

\subsubsection{Foreign trade policy in Ukraine}

In the Soviet Union, Ukraine was weakly integrated into the world trading system. Liberalisation of the foreign trade policy, therefore, was and is a very important task of the GOU reform package since Independence. The use of the country's comparative advantages along with meeting the preferences of the foreign buyers encourage the restructuring of the domestic firms and the improvement of the output quality, and foreign competition provides price signals from the world markets. This serves to recognise opportunity costs of production (or purchasing), to induce the effective resource allocation, to ensure output mix production, and to increase general economic efficiency. It was empirically proved in Ukraine that an export-oriented strategy encourages the firm restructuring and, thus improves their performance (AKIMOVA, 2001). In spite of certain progress in liberalising foreign trade, the GOU still has much to do to complete its real outward orientation.

Until 1999, Ukraine's foreign trade balance was always negative (see figure 28). From 1994 to 1998, the average deficit equalled to $-\$ 1$ bln. In 1999 Ukraine experienced the first positive balance in $\$ 1.8 \mathrm{bln}$. The foreign trade balance is the major part of the current account which improved from $-3.1 \%$ of GDP in 1994 to $3.6 \%$ of GDP in 2001 (NBU, 2002b).

Seven positions of Ukrainian trade account for over $90 \%$ of merchandise exports and imports (see table 12). The most important export goods are non-precious metal, chemical products, and agricultural and food (agri-food) products. In general, the Ukrainian export structure is insufficiently diverse and has a strong emphasis on the unreformed metallurgic and chemical industries which have questionable economic value (IER, 2002). 
Figure 28: Foreign trade of goods and services in Ukraine, 1994-2001

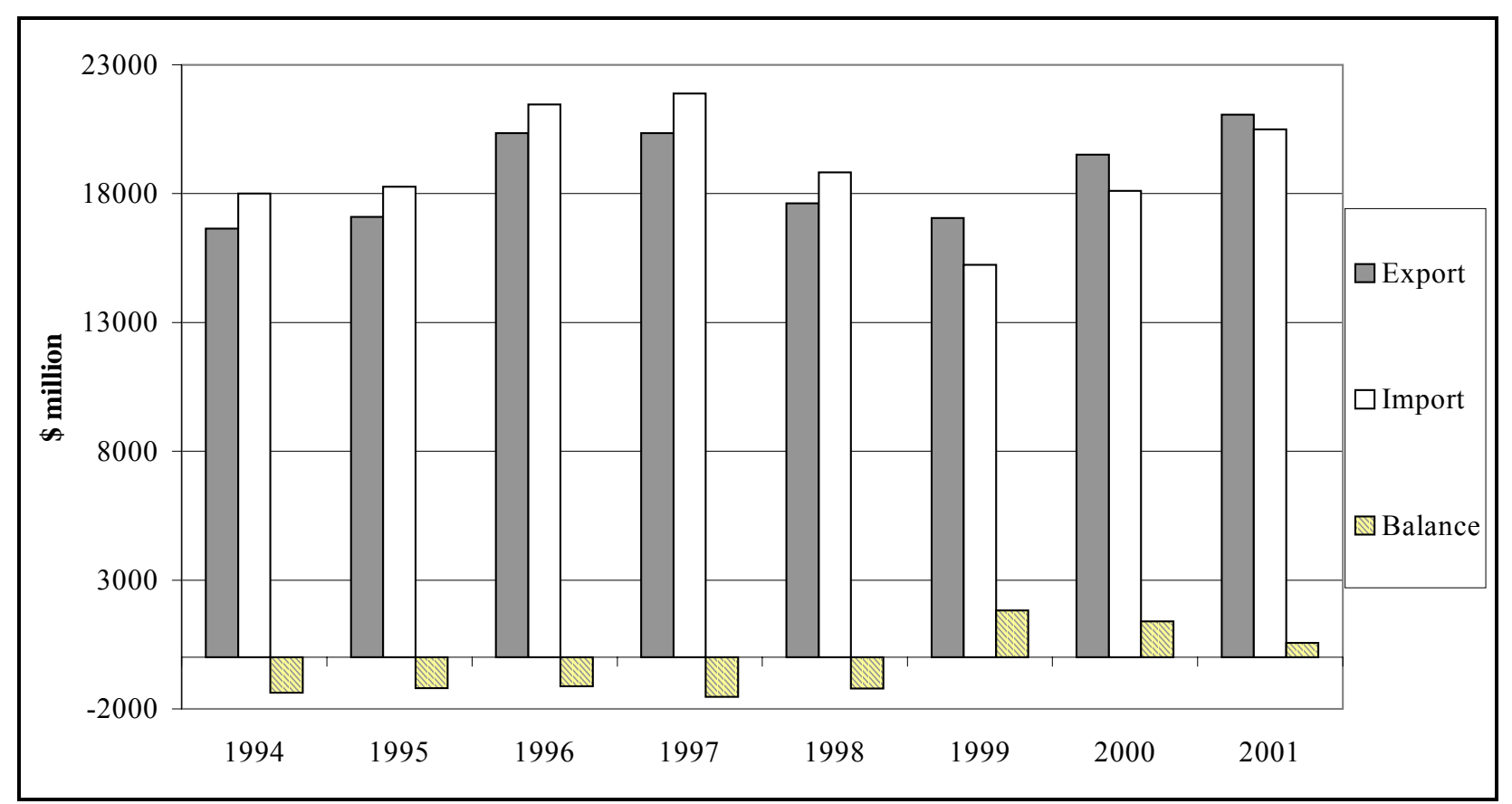

Source: UEPLAC (2002).

Table 12: Structure of merchandise exports and imports in Ukraine, 1994-2000, (in \% to total export and import)

\begin{tabular}{lrrrrrr}
\hline & $\mathbf{1 9 9 6}$ & $\mathbf{1 9 9 7}$ & $\mathbf{1 9 9 8}$ & $\mathbf{1 9 9 9}$ & $\mathbf{2 0 0 0}$ & $\mathbf{2 0 0 1}$ \\
\hline \hline \multicolumn{1}{c}{ Exports } & & & & & & \\
Agricultural and food products & 20 & 12 & 10 & 11 & 9 & 11 \\
Fuel and energy products & 7 & 7 & 7 & 8 & 8 & 9 \\
Chemicals & 14 & 13 & 13 & 11 & 12 & 11 \\
Wood and wood products & 1 & 1 & 2 & 3 & 3 & 3 \\
Textile & 4 & 4 & 5 & 5 & 5 & 5 \\
Non-precious metal & 30 & 38 & 39 & 39 & 42 & 39 \\
Machinery and equipment & 13 & 13 & 13 & 11 & 12 & 14 \\
\hline \hline & & & & & & \\
Agricultural and food products & 7 & 5 & 6 & 7 & 6 & 7 \\
Fuel and energy products & 45 & 42 & 38 & 42 & 43 & 39 \\
Chemicals & 10 & 11 & 11 & 11 & 11 & 12 \\
Wood and wood products & 3 & 3 & 3 & 3 & 3 & 4 \\
Textile & 4 & 4 & 5 & 5 & 5 & 5 \\
Non-precious metal & 4 & 3 & 4 & 3 & 5 & 5 \\
Machinery and equipment & 15 & 19 & 19 & 17 & 18 & 20 \\
\hline Source: UEPAC & & & & & &
\end{tabular}

Source: UEPLAC (2002).

The import of energy resources is dominated by Russia which accounts for $90 \%$ of total energy import bill. The level of the intra-industry trade is low and continues to decline (GOLOVEN, 2001). The geography of the foreign trade is not very diverse with around $40 \%$ of the exports going to the former USSR countries and over $60 \%$ to the rest of the world, while the import share with the former USSR amounts $58 \%$, mainly due to the import of energy resources (NBU, 2002a). 
Using the universal openness indicator (a ratio of sum of exports and imports of goods and services to official GDP (EDWARDS, 1997)), Ukrainian economy is open (see table 13). But it is well known that "the lion share of Ukraine's imports is made up of energy supplied from Russia and Turkmenistan, and that exports are largely composed of metallurgical products that in many cases are only competitive because the firms in question do not have to pay energy bills (which has led to many anti-dumping cases)" (ZORYA, 2001a: 42). Often such imports and exports are artificially supported by the state. The high apparent openness of Ukrainian economy, therefore, should be considered with caution.

Table 13: Openness of Ukraine's economy, 1994-2001

\begin{tabular}{lcccccccc}
\hline & $\mathbf{1 9 9 4}$ & $\mathbf{1 9 9 5}$ & $\mathbf{1 9 9 6}$ & $\mathbf{1 9 9 7}$ & $\mathbf{1 9 9 8}$ & $\mathbf{1 9 9 9}$ & $\mathbf{2 0 0 0}$ & $\mathbf{2 0 0 1}$ \\
\hline \hline Openness: $(\mathrm{X}+\mathrm{M}) /$ Nominal GDP & 0.91 & 0.96 & 0.94 & 0.84 & 0.87 & 1.03 & 1.18 & 1.11 \\
\hline
\end{tabular}

Source: Own calculations based on UEPLAC (2002).

The import tariffs in Ukraine are not very high, except for agri-food products (table 14). Over last years the average import tariff rate for industrial products equalled roughly $5 \%$, though exclusion of energy products (imported under zero tariff rates) raised the import tariff rate up to $10 \%$. Agricultural tariffs were significantly increased by the Law on State Regulation of Import of Agricultural and Food Products dated to July $1997 .^{22}$

Table 14: Trade weighted import tariffs in Ukraine, 1995-2001

\begin{tabular}{lccccccc}
\hline & $\mathbf{1 9 9 5}$ & $\mathbf{1 9 9 6}$ & $\mathbf{1 9 9 7}$ & $\mathbf{1 9 9 8}$ & $\mathbf{1 9 9 9}$ & $\mathbf{2 0 0 0}$ & $\mathbf{2 0 0 1}$ \\
\hline \hline Total & 4.2 & 5.1 & 4.1 & 7.5 & 7.5 & 7.5 & 7.5 \\
Total (without energy) & 6.4 & 7.5 & 6.7 & 12.6 & 12.6 & 12.6 & 12.6 \\
Industrial goods & 2.3 & 3.1 & 3.2 & 5.8 & 5.8 & 5.8 & 5.8 \\
Industrial goods (without energy) & 4.0 & 4.7 & 5.4 & 10.4 & 10.4 & 10.4 & 10.4 \\
Agri-food products & 15.2 & 17.1 & 22.7 & 25.9 & 25.9 & 26.0 & 26.0 \\
\hline
\end{tabular}

Note: $\quad$ In 2001, the rates of the import tariffs are assumed to equal to the rates in 2000.

Source: $\quad$ Adapted from QUAISSER (1999).

In spite of the relatively low rate of the import tariffs, non-tariff barriers in Ukraine are very high. At the beginning of transition, Ukraine had almost no explicit administrative barriers (MICHAELY, 1999). In 1996, the import regime became more restrictive mainly due to diversification of technical barriers to imports. The level of nontariff barrier index for 2001 was $195 \%$ of the 1996 level, showing a sharp increase in trade protection (MOVCHAN, 2002) ${ }^{23}$ According to Ukraine's Tax Administration, the import of oil products, machinery and equipment, vehicle, chemical products and foodstuffs is a subject to the most pervasive non-tariff trade barriers (ICPS, 2002).

\footnotetext{
${ }^{22}$ See section 3.2.6 with detailed description of the agricultural trade policy in Ukraine.

${ }^{23}$ Non-tariff barrier index incorporates the following measures: quotas, licenses, excise charges, anti-dumping measures, and minimum customs value.
} 
Moreover, Ukraine is not yet a member of the World Trade Organisation (WTO), though the accession negotiations have started in 1993. "The rent-seeking interests in the old industrial enterprises or even whole sectors of the economy and political weaknesses prevent the completion of the WTO accession which will negatively affect the long-term competitiveness of Ukrainian economy" (AHT, 2002: 1). The current status of the WTO negotiations proves that Ukraine's foreign trade is not yet liberalised to a level comparable with that of the other 136 members of the WTO, and this adversely affects the economic growth in the country.

The economic development of the country is negatively affected by carrying out a so-called 'import substitution strategy'. Distorted price signals from world markets and the closure of the domestic market from the modern technologies slow down economic growth since the use of ideas and knowledge is substituted by the distorted information about the opportunity costs of production and consumption (see IER, 2002: 21-27). The outward-oriented policy, therefore, is the only choice to sustain the economic development of the country in the long run. And the evidence suggests that Ukraine has still much to do to really liberalise both its import and export regimes. 


\subsection{Agricultural development in Ukraine during the last decade}

The analysis of the agricultural development during the last ten years is conducted here in a way to prepare the basis for empirical investigation of the impact of the macroeconomic policy on agriculture in Ukraine, and simultaneously, of the effects of agricultural performance and policy on the macroeconomic balance in the country. This section begins with the short presentation of the Soviet agriculture to further build the bridge between past and present, which is very important in considering recent agricultural transformation in Ukraine. Then the agricultural development is analysed by looking at output development, the role of the sector in the overall economy, structure of the farms, and agricultural fiscal and trade policies of Ukraine.

\subsubsection{Soviet agriculture}

Prior to analysing current farm policy in Ukraine, it is worthwhile reviewing Soviet-era agricultural policy. For 70 years prior to Independence in 1991, the central planning determined the structure of Ukraine's agricultural sector. Currently, it continues to influence the opinions of many agricultural policy makers.

The Soviet agricultural sector has consisted of large-scale state and collective farms. The rural economy was based mainly on the agricultural sector. Productivity improvement was not an objective. As a result, the total factor productivity in the USSR was the lowest in the world and declined over time (WONG and RUTTAN, 1990). Total subsidies directed to execute agricultural policy in the USSR were estimated to be RUB 90 bln in 1989 or $15 \%{ }^{24}$ of the total budget expenditures (JOHNSON, 1993a). The average PSE during 1986-1990 was 90.4\% (KWIECINSKI and PESCATORE, 2000), while, at the same time, the average Producer Support Estimate (PSE) in the USA and the EU was $25 \%$ and $44 \%$ correspondingly (OECD, 2000). Most farm support was provided through cheap inputs, in particularly fuel and fertilisers, subsidised credits, forgiven debts, and tax exemptions, i.e. the most trade and production distortive policy instruments.

Throughout the Soviet period, the farm management performance was judged, above all, by success in achieving planned gross output and sales to the state. Through its state order system, the state controlled both physical and capital input supply as well as output marketing. The 'first commandment' for the Soviet farm manager was fulfilment of the delivery plan. The resulting desire to meet the targets at all costs engendered a disregard for production costs and efficiency, which remains a prevalent attitude today (VAN ATTA et al., 1998). "Delivery plans were set so high that most farms had no hope of fulfilling them and remained chronically in debt to the state. These debts were periodically 'forgiven' by the state (most recently in 1982, 1985, and in 1991 in the USSR, and in 2000 in Ukraine), a practice which is the foundation of today's poor

\footnotetext{
${ }^{24}$ In 1989 the total budget income in the USSR was RUB 500 bln and the expenditures - RUB $600 \mathrm{bln}$. Thus, the total budget deficit equaled almost exactly the agricultural subsidies of RUB 100 bln.
} 
payment discipline and the lax attitude toward debt that is common in Ukrainian agriculture" (VON CRAMON-TAUBADEL and ZORYA, 2000: 166).

Agricultural and food pricing policy was characterised by centralised price determination. Producer and consumer prices were set without reference to international prices. Producer prices of individual commodities were generally established without reference to each other (e.g., animal feed was not priced with reference to livestock prices), since producers responded to centrally-determined production targets and not market signals. "The agricultural production in Ukraine was strongly biased in favour of livestock production, as in the late $1980^{\text {th }}$, for example, the rouble prices for grains and vegetables were $20-30 \%$ below international prices, while those for milk and meat products were 30-40\% higher" (WORLDBANK, 1994). Finally, consumer prices did not necessarily cover producer prices plus processing and marketing.

As a result, after gaining its Independence in 1991, Ukraine inherited highly distorted agricultural sector without private initiative and with wrong incentives concerning efficiency. Moreover, the market institutions such as land market, contract enforcement mechanisms, and/or bankruptcy procedure were absent.

\subsubsection{Development of agricultural output in Ukraine}

The development of the GAO in Ukraine is demonstrated in figure 29. The accumulated GAO of all farms has declined between 1991 and 1999 by $67 \%$, while during 2000 and 2001 it grew by 16\% (similarly to overall GDP presented in figure 18). During the whole period over $50 \%$ of the GAO was produced by the private sector, and the agricultural production in the private sector increased while that of collective farms declined. Over 55\% of the agricultural output were crop products, and around $45 \%-$ the livestock products (see table 15). But, in fact, the success of the private households was partially ensured through a strong cross subsidisation from the large farms. If the large farms were commercial, the private households would have hardly performed so well (KoESTER, 1999; TARASEVYCH, 1999; NEDOBOROVSKY, 2001).

Farm output performance in Ukraine lagged the performance of the advanced CEE countries, where the GAO had already recovered in 1993-1994 (see SWINNEN, 2001, figure 2). Worse macroeconomic conditions certainly played a negative role in the agricultural development of Ukraine, but the sectoral problems and government failures were also important determinants. The importance of the agriculture, its structure, farm support policy, as well as agricultural trade and price policy in Ukraine will be considered below. 
Figure 29: The GAO in Ukraine by type of farms, 1990-2001

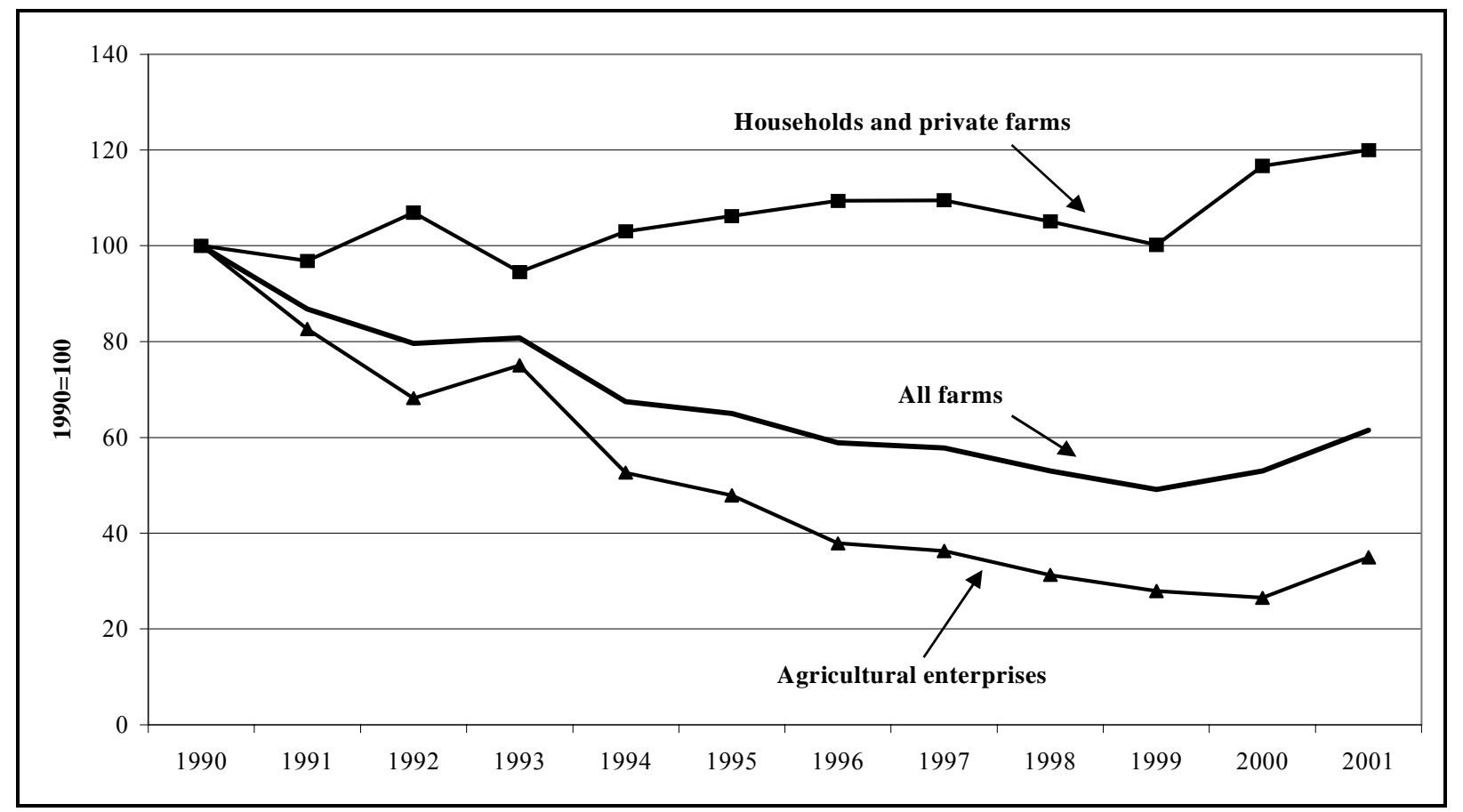

Source: State Statistics Committee of UkRaine (2001e).

Table 15: Production of selected agricultural products in Ukraine, 1985-2001, (in mln tons)

\begin{tabular}{lrrrrrrrrr}
\hline & $\mathbf{1 9 8 5}$ & $\mathbf{1 9 9 0}$ & $\mathbf{1 9 9 2}$ & $\mathbf{1 9 9 4}$ & $\mathbf{1 9 9 6}$ & $\mathbf{1 9 9 8}$ & $\mathbf{1 9 9 9}$ & $\mathbf{2 0 0 0}$ & $\mathbf{2 0 0 1}$ \\
\hline \hline Grains & 37.9 & 51.0 & 38.5 & 35.5 & 24.6 & 26.5 & 24.4 & 24.4 & 39.7 \\
Sunflower & 2.3 & 2.6 & 2.1 & 1.6 & 2.1 & 2.3 & 2.7 & 3.5 & 2.3 \\
Sugarbeet & 39.0 & 44.3 & 28.8 & 28.1 & 23.0 & 15.3 & 13.9 & 13.2 & 15.5 \\
Potatoes & 20.0 & 16.7 & 20.3 & 16.1 & 18.4 & 15.3 & 12.8 & 20.2 & 20.3 \\
Milk & 23.0 & 24.5 & 19.1 & 18.1 & 15.8 & 13.7 & 13.4 & 12.6 & 13.4 \\
Meat & 3.7 & 4.4 & 3.4 & 2.7 & 2.1 & 1.7 & 1.7 & 1.7 & 1.5 \\
Eggs (bln) & 16.6 & 16.3 & 13.5 & 10.2 & 8.8 & 8.3 & 8.8 & 8.7 & 8.7 \\
\hline Source
\end{tabular}

Source: $\quad$ StATE StATISTICs COMMITTEE OF UkRAINE (2001e).

\subsubsection{Importance of agriculture for Ukrainian economy}

Agriculture plays an important role in Ukrainian economy (see table 16). Agricultural land occupies 69\% (41.9 mln ha) of all land resources in Ukraine. According to the official statistics, over $23 \%$ of the employed population works in the agricultural sector and together with employment in the food processing industry and related transportation, catering, storage and logistics that form so-called agri-food sector, employment reaches around $40 \%$ of the working population (SSCU, 2001e). The importance of the agriculture is especially felt in the rural areas where around $70 \%$ of the working rural population are farming-dependent in this or another way.

Concerning agricultural employment, it is important to distinguish between labour employed by the large agricultural enterprises and those working on the private 
household plots. This distinction is important for further analysis of the farm support in Ukraine (for example see section 3.2.5). Over 1997-2001 an average share of the large farms' labour equalled roughly $13 \%$ of the national employment (in contrast to often stated 24\%) (SSCU, 2001e).

Table 16: Role of agriculture in Ukrainian economy, 1991-2001

$\begin{array}{llllllll}1991 & 1993 & 1995 & 1997 & 1998 & 1999 & 2000 & 2001\end{array}$

\begin{tabular}{lcccccccc}
\hline \hline $\begin{array}{l}\text { Agricultural labour force, thousand } \\
\text { people }\end{array}$ & 4921 & 4874 & 5258 & 4935 & 5028 & 4932 & 4934 & 5000 \\
$\begin{array}{l}\text { Share of agricultural labour force in total } \\
\text { employment, \% }\end{array}$ & 19.1 & 20.4 & 22.2 & 22.1 & 22.5 & 22.6 & 23.2 & 23.7 \\
$\begin{array}{l}\text { Share of agricultural labour force } \\
\text { employed by large farms, in \% from total }\end{array}$ & 17.1 & 16.6 & 15.1 & 13.1 & 13.2 & 12.8 & 12.9 & 11.5 \\
$\begin{array}{l}\text { Share of agriculture in GDP, \% } \\
\text { Share of agri-food exports in total }\end{array}$ & 21.8 & 21.5 & 14.6 & 12.1 & 11.2 & 11.4 & 14.0 & 14.7 \\
$\begin{array}{l}\text { merchandise exports, \% } \\
\text { Share of agri-food imports in total } \\
\text { merchandise imports, \% }\end{array}$ & na & 13.1 & 18.7 & 11.7 & 10.1 & 11.4 & 8.9 & 10.7 \\
\hline
\end{tabular}

Note: na - data is not available.

Source: $\quad$ State Statistics Committee of Ukraine (2001e) and NBU (2002a).

The share of agriculture in the total GDP of Ukraine, in average, equals $15 \%$ for the period from 1991 to 2001, though its share first sharply decreased from $21.8 \%$ in 1991 to around $11.6 \%$ in 1997-1999, and then grew again to $14 \%(14.7 \%)$ in 2000 (2001). Agriculture along with the food processing sector was among the fastest growing sectors in 2000 and 2001. Assuming $4.5 \%$ of the share of the food processing industry in the GDP, the share of the agri-food sector grew up to around $20 \%$ of Ukrainian GDP in $2001 .^{25}$

The agri-food sector plays an important role in determining the trade balance and the current account. During 1994-2001, the share of the agri-food in the total merchandise exports has been $13 \%$, ranking behind only metal, chemical, and machinery exports (IER, 2002). The share of agri-food imports equals to 6\%. Moreover, the agrifood sector accounts for a large share of the foreign direct investments in Ukraine. By the end of 2000 , the food processing industry alone attracted $\$ 776 \mathrm{mln}$ or $20 \%$ of the total accumulated foreign direct investments, while the share of agriculture was only $2 \%$ (SSCU, 2001f). "Taking into account the large capital outflows in 2000 and 2001, the capital inflows into the agri-food sector were especially important for the capital account balance and Ukraine's balance of payments" (IER, 2002: 24).

${ }^{25}$ Ukrainian statistics does not provide data on the share of food industry in total GDP. Rather, information about the share of the food processing industry in the industrial output is available. Assuming close correlation between the share of output and the sectoral GDP as well as considering the share of the industry in total GDP, the share of the food processing GDP can be calculated. 
Based on the above presented data, it is obvious that agriculture is an important sector of Ukraine's economy. Overall economic growth, therefore, cannot be achieved without reforms in agriculture and the creation of the commercially viable and efficient farms. The role of agriculture in Ukraine's economy is much larger than in the OECD countries, and it is expected, therefore, that in Ukraine, the agriculture should contribute to the economic growth, instead of extracting resources from non-agricultural sector.

\subsubsection{Structure of the agricultural sector in Ukraine}

Real reforms of the agricultural enterprises in Ukraine started only after the issuance of the Presidential Decree No. 1529/99 "On the Urgent Measures for Accelerating the Restructuring of the Agricultural Sector of the Economy" dated December 3, 1999. Before 2000, the structure of the Ukrainian agricultural sector did not differ significantly from the structure of Soviet agriculture. At the outset of transition, most farms (around 14000) were redefined as collective agricultural enterprises (CAE), which hardly differed from 'kolkhoses'. In 1999 they possessed $63 \%$ of the total agricultural area (PUHACHOV and PUHACHOVA, 2001). The average sized CAE disposed of around 2000 ha of the agricultural land. At the same time, though the number of the private farms in Ukraine grew from 82 in 1991 to 35485 in 1999, their average size was only 29 ha per farm and their role in the total agricultural output was insignificant (PUHACHOV and PUhachova, 2001). Finally, over the transition period, the subsidiary households, possessing around $12 \%$ of the agricultural land or 0.5 ha per family, have become the important agricultural producers, producing much more than required for their subsistence (see figure 22). In 1998, for example, 60\% of households, surveyed by the WORLD BANK, reported sales of farm products from household plots, and these households sold on average about half of their output (LERMAN and CSAKI, 1999). The importance of the private households is especially visible in the livestock sector, where around $60 \%$ of all milk and meat is produced (SSCU, 2001e).

The dual structure of Ukrainian agriculture - the co-existence of the very large collective farms and very small private households - did not appear from nothing. Frankly, many Ukrainian politicians wanted such a structure for the agriculture, since large agricultural enterprises could serve a social shelter for the rural inhabitants during the transition period. To preserve the large farms, land market formation and the introduction of farm bankruptcy procedures were hampered until 1999. The peasants rationally reacted to incentives. Being the members of the collective agricultural enterprises, private householders were allowed, and sometimes encouraged, to shift the production, their working time and capital from the CAEs to their private plots. The organisational structure of the large farms with their high transaction costs and complex decision-making procedure drove agricultural production into the household sector and simultaneously led to the decline in the CAEs (KOESTER, 1999). Private households were cross subsidised by the large farms either in the form of low-priced feed or other inputs purchased from the CAEs or 'in-kind' wages (NEDOBOROVSKY, 2001). Moreover, with the private households not paying any taxes (income tax or value-added tax, for example) have further encouraged the members of the CAEs to shift the production from the taxable official sector to the free-tax household zone. As a result, this structure of Ukrainian agriculture has substantially contributed to the overall inefficiency of the agricultural sector through creating impediments for the large farms to adjust to the new 
economic conditions and become really commercial (during 1995-1999, around 70\% of all CAEs reported net losses). Hence, instead of contributing to the overall economic growth of the country, during 1991-1999 the agricultural sector extracted resources from the non-agriculture.

After the issuance of the above mentioned Presidential Decree in December 1999, "all members of the CAEs were granted the right to leave these CAEs freely and withdraw their land and property shares" (PUHACHOV and PUHACHOVA, 2001: 196). Within one year the CAEs have disappeared and on their base different types of the farms were created. These farms remained large, but, as a rule, farm operators leased land and assets from their own workers and paid leasing payments in turn. Decision-making in most farms has become more transparent and simple, because managers of the farms instead of the general meetings - were making business decisions. Clearer property rights and lower transaction costs in farm decision-making have greatly contributed to the agricultural growth in 2000 and 2001 so that in 2000 (2001) 50\% (67\%) of all farms reported net profits (see figure 30 ).

Since recently, the share of the competitive farms in Ukraine started to grow, and approximately $20 \%$ of the large farms appear to be internationally competitive in producing milk, grain, and oil seeds (VENEMA, 2002; ZORYA and VON CRAMONTAUBADEL, 2002). Use of substantial internal reserves will probably permit many good farms to operate successfully foreseeable future, but already in the medium run even these farms will have to further improve management and to invest into new machinery and technologies to sustain their competitiveness.

Figure 30: Distribution of the farms on the rate of profitability in Ukraine in 2000

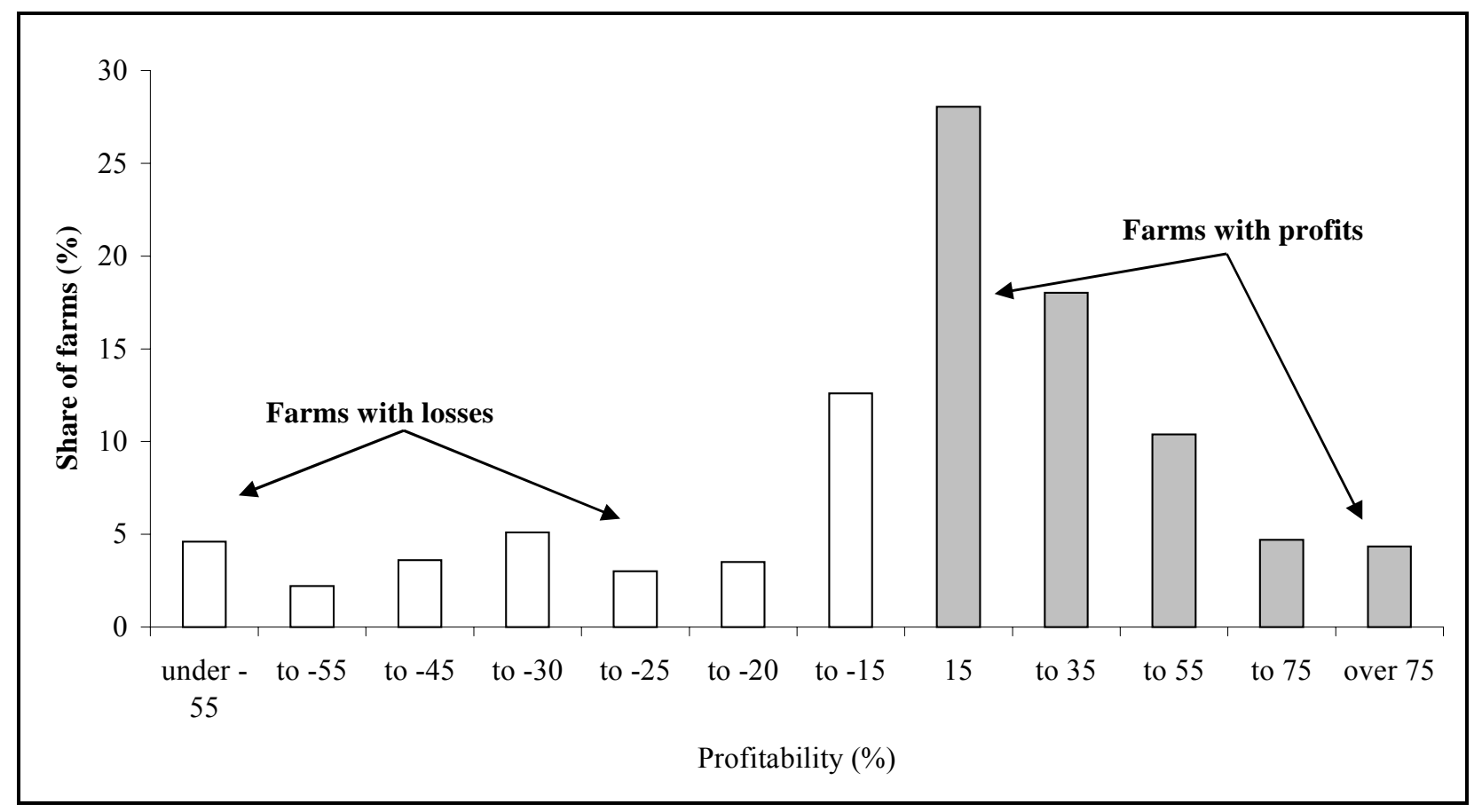

Note: The rate of profitability is calculated as the profit (revenue minus total production and marketing costs) to the total costs.

Source: State Statistics Committee of Ukraine (2001e). 
At the same time, the average level of the farm efficiency and the competitiveness remains very low. Since 2000, the farms enjoy substantial tax privileges. Low tax burden ensures survival of many farms irrespective of efficiency. Also, the capital from the nonagricultural sector is being invested in agriculture, and huge agri-holdings are being created - often for the purpose for optimising tax payments (DEMYANENKO and ZORYA, 2002; LAKEMEYER, 2002). Hence, further creation of the market institutions and abolishment of the distortive subsidies are crucial to ensure the growth of the number of the viable commercial farms in Ukraine.

\subsubsection{Farm support policy in Ukraine}

Supportive farm policies are seen by GOU as an essential part of the agricultural policy to ensure farm profitability and to accelerate the agricultural development as a whole. Until 2000, there was little indication that the GOU changed its attitude to the farm support compared with the Soviet times. State support of the farms remained to be highly distortive, and the GOU intervened severely in the input supply, agricultural production, and output marketing. As the low budget revenues constrained direct subsidies, indirect support prevailed during this period. Main support instruments included zero-interest budget loans, debt restructuring and write-offs, tax exemptions, supply of agricultural machinery and equipment via the State Leasing Fund and state sovereign guarantees against foreign credits (VON CRAMON-TAUBADEL and ZORYA, 2000). The largest portion of these instruments are highly invisible, have many negative economy-wide effects, and thus, considered everywhere as the most distortive. In 2000, the GOU substantially changed its agricultural policy in respect to the transparency of the policy instruments and encouraged the private initiative by withdrawing itself from the input and output markets. The estimations of monetary values of the farm support in Ukraine are presented in table $17 .^{26}$

Before considering the state support indicators, a few words of caution have to be said. Neither the State Statistics Committee nor the Ministry of Agricultural Policy of Ukraine provides data on farm support. Moreover, there are no independently conducted estimations of the Producer and Consumer Support Estimate in Ukraine as was done for Russia by the OECD. The calculations, therefore, are based on information presented by both official and media sources, which were difficult to collect for the period until 1998. Although the figures may be greatly distorted for the individual items, the total farm support estimations are very close to the reality (see also KoBUTA and SHEVZOV, 2002).

\footnotetext{
${ }^{26}$ Here only a support from tax payers is estimated. A support of farmers from consumers, which is a part of well-known OECD PSE indicator, is not considered not to confuse the readers with possible deviations from official PSE and CSE calculations for Ukraine expected to appear in the near future from the OECD.
} 
Table 17: State budget support of the farms in Ukraine, 1998-2001, (UAH mln)

\begin{tabular}{lrrrr}
\hline & $\mathbf{1 9 9 8}$ & $\mathbf{1 9 9 9}$ & $\mathbf{2 0 0 0}$ & $\mathbf{2 0 0 1}$ \\
\hline \hline Debts on budget loans & 1241 & 1098 & 0 & 0 \\
Farm debt write-offs & 70 & 41 & 0 & 129 \\
Debt restructuring & 140 & 200 & na & 236 \\
Tax exemptions & na & 2259 & 2208 & 1893 \\
Tax arrears & 915 & 599 & $0 *$ & $0 *$ \\
Subsidies to livestock producers & 168 & 400 & 680 & 684 \\
Interest rate compensation & 0 & 0 & 51 & 150 \\
Cattle weight payments & 0 & 0 & 0 & 125 \\
Farm debts for machinery supplied by the State Leasing Fund & 4 & 15 & na & na \\
Farm debts for foreign machinery purchased under the state & 90 & 162 & 300 & 276 \\
Livestock breeding and crop selection & na & 44 & 30 & 106 \\
Other production support & 176 & 122 & 65 & 238 \\
'Green box' financial support** & 414 & 491 & 446 & 605 \\
\hline Total farm state support & $\mathbf{3 2 5 3}$ & $\mathbf{5 5 7 5}$ & $\mathbf{3 7 8 0}$ & $\mathbf{4 4 4 2}$ \\
\hline Note: & At the end of 2000 and 2001, farmers had the tax debts at UAH 101 and 75 \\
$\quad$ correspondingly. But in contrast to 1998 and 1999, these debts were collected. & \\
$\quad * *$ 'Green box' measures are the WTO definition of the support measures which
\end{tabular}

Source: $\quad$ Own presentation based on Ministry of Agricultural Policy of Ukraine (1992-2000) and VERKHOVNA RADA (diff. years).

Until 2000, the main instrument of the agricultural support were budget loans in the form of fuel, fertilisers or feed grains provided to the farms through state input suppliers such as the 'Khlib Ukrainy' or 'Ukragrokhim' (SEDIK et al., 2000). Inherited from the Soviet time incentives not to pay their bills and soft budget constraints applied to both agricultural enterprises and state input suppliers resulted in the accumulation of the significant debts of farms against input suppliers and, correspondingly, by state input suppliers against the state budget. At the end of 1999, the farms owed state suppliers UAH 2.4 bln, while only 'Khlib Ukrainy' owed to the budget UAH 1.3 bln (ACU, 2000). Inability of the GOU to collect budget loan debts also encouraged many farms not to pay their tax bills. According to CHAPKO (2000), in 1991 the level of the fulfilment of tax obligations by the farms was 75\% from accrued taxes, while in 1999 this level declined to $53 \%$.

Adding to weak tax payment discipline and accumulated tax arrears, farmers were also granted different tax exemptions. In 1999, the fixed agricultural tax (FAT) was introduced, which integrated twelve taxes previously paid by the farms. ${ }^{27}$ The FAT will

${ }^{27}$ See Law of Ukraine “On Fixed Agricultural Tax” dated December 17, 1998. 
be in effect until 2004 and represent the large subsidy for farms. Thus, the tax burden was decreased from UAH 98 per ha to UAH 20 per ha (DEMYANENKO and ZORYA, 2002). In 1999-2000, the farms paid only $70 \%$ of this tax, leaving out payments to the local budgets. Moreover, since 1999, the farms were exempted from paying the VAT which increased the farm income additionally by UAH $493 \mathrm{mln}$ per year (MINAGRO, 2002).

In addition, farms sold their meat and milk at zero VAT rate. At the same time, the processing plants had to return $70 \%$ of the VAT received from sale of meat and dairy products (Ministry of Agricultural Policy accumulated another 30\% to finance the livestock breeding programs). Also, the farmers received agricultural machinery and equipment from the State Leasing Fund and foreign machinery (U.S. John Deere and Case Corporation) from the state suppliers, for which they were also reluctant to pay (see table 16).

The GOU, being unable to provide capital investments to the farms itself, crowded out the private investments. In 1990, the share of agriculture in total capital investments was $21 \%$, while in 2001 it decreased to $5 \%$. The investment quota in agriculture (total capital investments to nominal agricultural GDP) declined from $1.5 \%$ in 1996 to $0.6 \%$ in 2000 , while the investment quota in industry remained at relatively stable level of $7 \%$ (SSCU, 2001f).

In 2000, the GOU wrote off the farms' state debts, withdraw itself from the input supply market, and introduced the partial compensation scheme for the interest rate paid by the farms for commercial credits. Moreover, additional payments for cattle weight were introduced to stimulate the cattle growing. The GOU achieved significant results in having its support not only more transparent and less distortive, but keeping it lower in relation to the GAO and especially agricultural GDP (see table 18).

\section{Table 18: Significance of state farm support in Ukraine, 1998-2001}

\begin{tabular}{lrrrr}
\hline & $\mathbf{1 9 9 8}$ & $\mathbf{1 9 9 9}$ & $\mathbf{2 0 0 0}$ & $\mathbf{2 0 0 1}$ \\
\hline \hline State farm support, UAH mln & 3253 & 5575 & 3780 & 4442 \\
State support as a share of farm gross receipts, \% & 9.0 & 13.0 & 6.8 & 6.4 \\
State support as a share of large farm gross receipts, \% & 19.2 & 27.2 & 17.0 & 15.6 \\
State farm support as a share of agricultural GDP, \% & 28.3 & 37.6 & 19.9 & 14.5 \\
State farm support as a share of total GDP, \% & 3.2 & 4.3 & 2.2 & 2.1 \\
\hline
\end{tabular}

Note: $\quad$ Under the methodology of the OECD, farm gross receipts are the sum of the gross agricultural production estimated at the farm-gate prices plus state budgetary support.

Source: $\quad$ Own calculations based on State Statistics Committee of Ukraine (2001E) and UEPLAC (2002).

With the cancellation of the budget loans, the introduction of the fixed agricultural tax and VAT tax exemptions, local authorities lost their major channels to intervene into farm decision-making. This has greatly contributed to economic growth through rational activities of many farm managers (DEMYANENKO and ZORYA, 2002). Despite these achievements, farm support is continued to be based on the relatively distortive policy instruments, such as tax exemptions and production stimulation (e.g. of milk and meat production) instead of the visible budgetary expenditures, while the share of the 'green box' measures - the most desirable for the agricultural development and thus, excluded 
by the WTO from the countries' support commitments - remains very low $(12 \%$ of total support on average). In addition to support measures presented in tables 16 and 17, in 2000 the GOU introduced the sugar quota system which is also a distortive policy instrument. In 2001, for example, the cost of financing of this quota (by consumers) is estimated to equal UAH $298 \mathrm{mln}$ (see KOBUTA and SHEVZOV, 2002).

State farm support in Ukraine remains high compared with other countries. According to the OECD (2000), farm support as a share of total GDP in OECD countries in 1997-1999 was $1.4 \%$, declining from $2.3 \%$ in $1986-1988$. However it varies from $0.4 \%$ in New Zealand to $3 \%$ in Switzerland. The EU rate equalled to $1.7 \%$ and U.S. farm support was $1 \%$ of total GDP. ${ }^{28}$ The share of farm support in Ukraine's GPD during $1998-2001$ equalled roughly $2.9 \%$ - this ratio is even higher than in many developed economies.

The Producer Support Estimate, measured as the percentage share of the farm support in the total value of the gross farm receipts, was $40 \%$ for OECD countries in 1997-1999, again varying from 2\% in New Zealand to 70\% in Switzerland (OECD, 2000). If five countries with very high farm support (namely, Switzerland, Korea, Norway, Japan, and Iceland) are excluded, average PSE will be equal $20 \%$. In Ukraine, during 1998-1999, the share of the state support in the farm gross receipts equalled to $10 \%$, reaching the level of many rich OECD countries. Finally, the biggest part of the subsidies in Ukraine are directed to the large agricultural enterprises, which produce only a little over $50 \%$ of the GAO (UEPLAC, 2002). Recalculating the ratio of the state support to farm gross receipts of large-scale farms gives much higher level of the support - from $27 \%$ in 1999 to $16 \%$ in 2001 (compared with 13\% in 1999 and $6 \%$ in 2001 when all farms are considered as in table 17). Despite a significant state support, especially until 2000, the efficiency of most farms in Ukraine was very low and decreased over time (Kurkalova and Jensen, 1996; Murova, 2000; Lissitsa and Odening, 2001). The relationship between state farm support and the GAO is demonstrated in figure 31 .

High and distortive farm support during 1998-1999 initiated the output decline. Significant decrease of the state support and switch to more market-friendly policy instruments in 2000 ensured the agricultural growth. Moreover, in 2000 the farms enjoyed high grain prices (due to the shift from export to import situation on the grain market and high import tariffs for grain) that allowed them to finance sowing and harvest campaigns in 2001. In this period the GOU did not intervene in the price formation permitting 'right' signals from the market, and this stimulated better resource allocation. In 2001, real farm support grew and the real GAO increased by $16 \%$. Surely, the farmers responded to the higher state support, but why it did not take place in 1998-1999? Because not only the farm support itself matters, but also the manner in which support is provided and its impact on farm-gate price formation. As the former aspect was discussed earlier, the latter will be considered in the next section.

\footnotetext{
${ }^{28}$ Note that the farm support measurement in the OECD countries includes not only the budget support, but also the consumers expenditures. The latter equals roughly $60 \%$ of all support. In the case of Ukraine, only the budgetary support is accounted for. Thus, comparable share of farm support in the GDP of the OECD countries should be reduced by roughly $60 \%$ to be compared with the Ukrainian figure.
} 


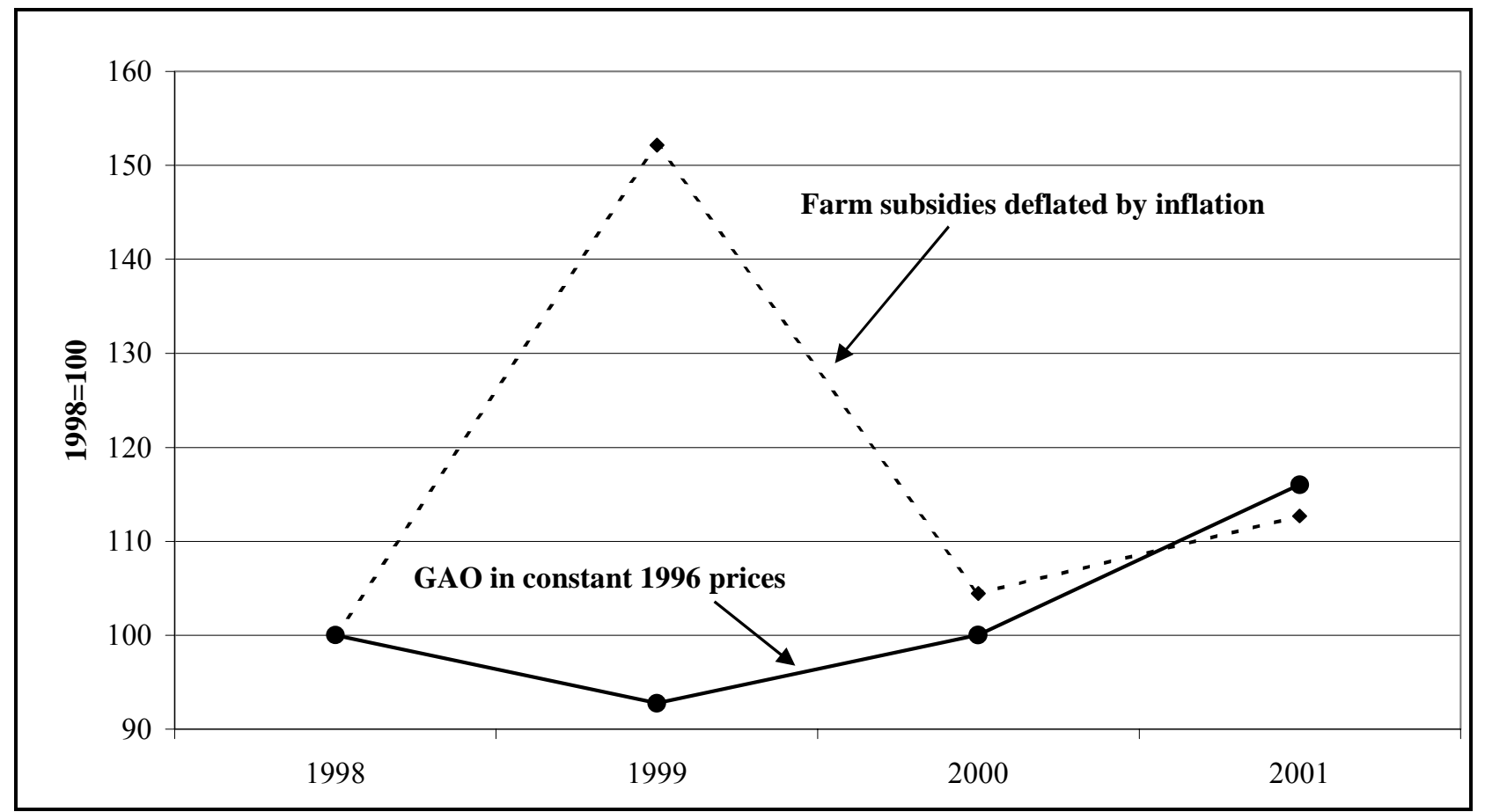

Source:

Own presentation based on UEPLAC (2002) and table 17.

\subsubsection{Agricultural trade and pricing policy in Ukraine}

The Soviet agriculture was characterised by highly distortive price relationships (see section 3.2.1) and weak international integration in the world trading system (see section 3.1.4). At the beginning of transition, Ukraine was expected to go through significant price shock in terms of the correcting not only absolute, but also the relative prices (LIEFERT and SWINNEN, 2002). Moreover, the prices for agricultural products were expected to grow much slower (the livestock prices were even expected to decline) than the prices for industrial goods, especially energy products, as the level of the latter had been much lower than the former ones compared with the world market prices, i.e. declining agricultural 'terms of trade' (see figure 32).

The expected trend of such a price development was not unique for Ukraine. Most CEE countries experienced similar 'price shock' and, according to SWINNEN (2001), this initial decline of the agricultural terms of trade led to a reduction in farm output of 40$50 \%$ in those countries over 1989-1995. In the most CEE countries the agricultural terms of trade continued declining, following the common world trend of declining agricultural prices. However, an increase of agricultural productivity and trade liberalisation moderated the real price decline and increased factoral terms of trade which takes into account productivity improvements (see SIRIN and ZORYA, 2001). In Ukraine, in contrast, both foreign and domestic trade were liberalised only to a certain extent, food prices (or often retail margins) continued to be administrated, and the agricultural productivity started to grow only in 2000. At the same time, prices for industrial goods were 'relatively' liberalised. That substantially strengthened the 'natural' worsening of the 
agricultural terms of trade (see figure 33). Below it will be discussed whether agricultural prices were 'right' or whether they could have been higher (or lower) if certain measures were undertaken on time.

Figure 32: The ratio between prices in the Soviet Union and on world markets

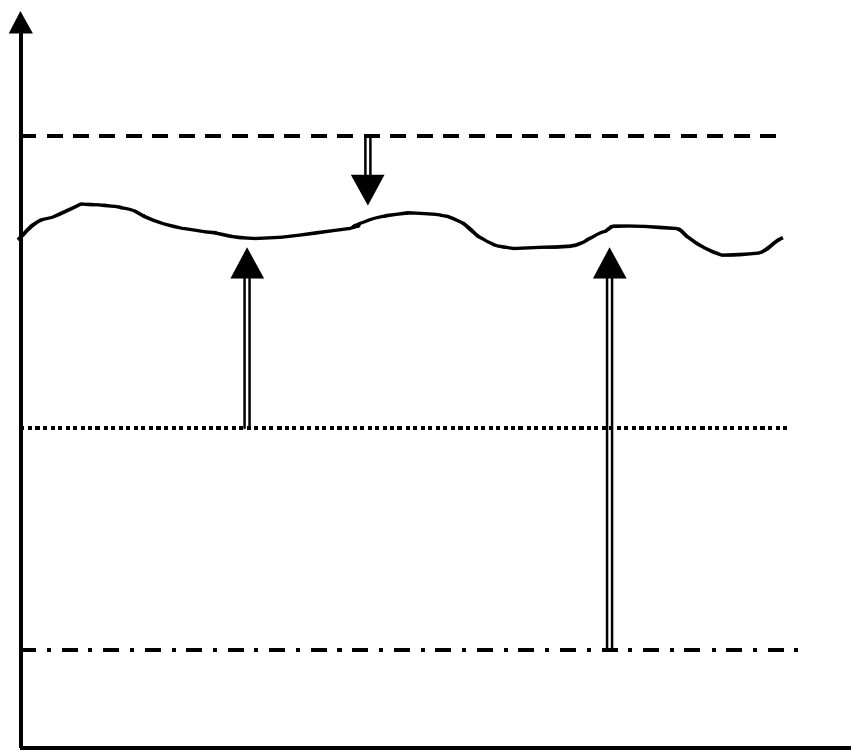

Domestic prices for livestock
products in Ukraine in mid-1992

World market prices

Domestic prices for crop products in Ukraine in mid-1992

Domestic prices for energy products in Ukraine in mid-1992

Source: $\quad$ Own presentation based on BROOKS (1993: 419).

Figure 33: The price indexes for selected products in Ukraine, 1991-2000

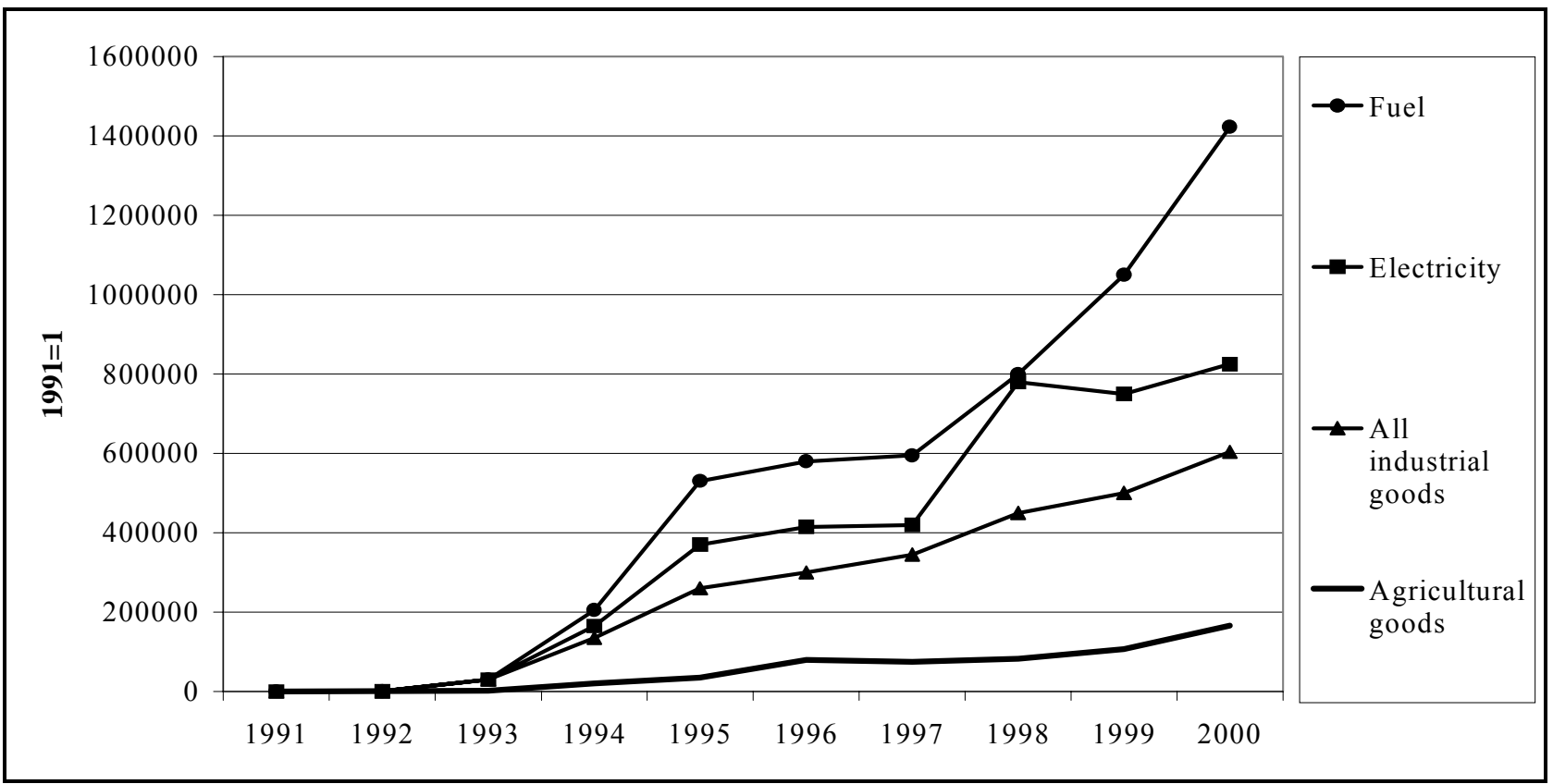

Source: $\quad$ State Statistics CommitteE of Ukraine (2001e).

\subsubsection{Export policy}

After Ukraine became independent in 1991, a universal system of intensive and pervasive state restrictions on exports was imposed, which reached their apex at the end 
of 1993 (MICHAELY, 1999). ${ }^{29}$ Agricultural exports were constrained by both price and quantitative regulations, with high export taxes (most exportable agricultural products subject to rates between 35 and 50\%) and surrender requirements that greatly reduced exporters' income because of the low official exchange rate. Moreover, export quotas and licensing requirements were part of this pervasive system. In December 1993 the export restrictions were relaxed, and the liberalisation of the export transactions was largely completed by 1996. But after the cancellation of all export taxes and quotas, in May 1996, Ukraine established export tax for live animals and hides ranging from 50 to $75 \%$. With this export tax, the GOU intended to stop the decline of the cattle herd, but as time shows, this tax hardly helped to resolve this problem, as it was not related to the real reasons for the cattle herd decrease (i.e. the low profitability of livestock production).

Furthermore, the desire to fill domestic vegetable oil processing capacities encouraged the GOU to limit the exports of sunflower seeds, though this crop was the most profitable cash product in Ukraine in 1996-1998 (VON CRAMON-TAUBADEL and STRIEWE, 1999). In 1998, the Presidential Decree set exporter deposit system for export of sunflower seeds and in September 1999, 23\% of export tax for oil seeds was introduced (accompanied by high 'indicative' export price). In 2001, the export tax for oil seeds was reduced to $17 \%$ with simultaneous prohibiting of so-called 'give-and-take operations'. ${ }^{30}$ This greatly increased the real taxation of farmers through lowering their farm-gate prices, but not really resolved the initial problem - low efficiency of vegetable oil refineries in Ukraine.

Export of other agricultural products is theoretically free, but in practice there are many artificial impediments for private traders. Since 1996, the export of cash commodities such as grain and sunflower seeds was constrained by the regional bans (VON CRAMON-TAUBADEL and ZORYA, 2001). Even in 2001, when Ukraine harvested 40 mln tons of grain and domestic demand was estimated to be $22 \mathrm{mln}$ tons, some oblasts did not allow the moving of grain outside, 'ensuring' their food security (VERNITSKY, 2001). ZORYA (2001b), using the spatial equilibrium regional trade model based on Takayama \& Judge quadratic programming approach for Ukraine, found that not only agricultural producers in banned oblast lost revenue, but also that farmers in other oblasts were negatively affected. "Producer surplus falls due to the increased transportation costs (and consequently falling farm-gate prices) as traders attempt to avoid the oblast that has imposed the ban" (ZORYA, 2001b: 152). In addition to the regional bans for crop products, the barriers on intra-oblast (and even intra-rayon) trade for milk have been even more restrictive. According to SAUER (2002), the difference of milk prices in Donetsk and Dnipropetrovsk oblasts in 1999 equalled to $35 \%$, that could not be explained by only transport costs, but rather by administrative barriers that significantly reduced the farmgate prices and thus, the profitability of the agricultural production.

\footnotetext{
${ }^{29}$ See also the Appendix in VON CRAMON-TAUBADEL et al. (2001) with detailed historical review of the agricultural policy in Ukraine.

${ }^{30}$ Give-and-take operations are intensively used in many 'barterised' CIS transition economies. The seller 'gives' his raw materials for processing and then 'takes' finished good back by paying processing costs partially by given materials. These operations allow either avoiding taxes or compensating cash shortages.
} 
Finally, agricultural exports, and therefore, farm income, were also constrained by the poorly-developed export infrastructure and pervasive export administration. ${ }^{31}$ The issue of the high export marketing costs in Ukraine is well documented. According to STRIEWE and VON CRAMON-TAUBADEL (1999), Ukrainian farmers get only $40 \%$ of the FOB export price from the export of grain, while their German 'colleagues' get $70 \%$ of the FOB price. ZORYA (2001b) estimated that in 1999, Ukrainian wheat producers have lost $\$ 23$ per ton or $\$ 55$ per ha because of inflated (higher than 'natural') marketing costs. ${ }^{32}$ SEDIK (2000) estimated that during 1994-1997 the costs to move the agricultural commodity to the border in Ukraine had substantially exceeded U.S. benchmark costs for wheat, sunflower seeds and sugar beet, while they were lower for meat and milk products. The large grain harvest in 2001 made the policy makers pay more attention to the transactions costs to store, transport and handle grain and certain promising steps have already been made. Other constraints include non-repayment of the VAT to the exporters, ${ }^{33}$ surrender requirements for exporters to sell half of their foreign exchange proceeds (renewed after financial crisis of 1998) and compulsory registration of the export contracts on agrarian exchanges.

\subsubsection{Import policy ${ }^{34}$}

At the outset of economic transition, Ukrainian agricultural import policy developed under opposite scenario of an export one. Ukraine had almost no explicit tariffs and the administrative or quantitative barriers on import. "The import regime remained relatively free through 1992. In early 1993, a tariff system was introduced; but tariff levels were universally modest, and almost no non-tariff barriers existed other than a standardisation requirement that mostly accepted adherence to international standards" (MiCHAELY, 1999: 5). But by the spring of 1996, the import regime for agricultural products has become more restrictive. In July 1997 the Law on State Regulation of

31 According to KROT (2002), the following documents are necessary to export: certificate of origin, veterinary certificate for forage grain, certificate for safety of cargo for captain of the vessel and chief of the port, certificate of fumigation, phyto-sanitary certificate, quality certificate from State bread inspection, price certificate, etc. In most cases, these certificates are not accepted by the other countries and, therefore, have to be received once more from the internationally certified agencies.

32 The calculations are based on 'natural' export marketing costs that inevitably occur to move, for instance, grain from the field on board of the export trailer. The 'natural' costs are assumed to equal to the export costs in the Western Europe. The actual costs in Ukraine are at least twice as high as the 'natural' costs. Note that in our case the marketing costs include not only pure marketing costs, but the harvest and storage losses on the farm level that greatly contribute to the total farm losses.

${ }^{33}$ According to the economic journal Business (from January 13, 2002), the budget debts on VAT to exporters are around UAH 5.8 bln or $2.9 \%$ of Ukraine's GDP. The main problem for farmers is that many exporters add the unpaid export VAT to their expenses further decreasing farm-gate prices. See also DEMYANENKO and ZORYA (2002) and PRIKHODKO (2002).

${ }^{34}$ I would like to thank TATYANA REDINA for providing data and suggestions for this section.

35 "Explicit" - because the barriers implied by restricted access to foreign exchange, or by the need to get into a barter deal with a Russian firm, is very important. 
Agricultural Imports was approved, which currently regulates agricultural and food imports to Ukraine. This Law has established high ad valorem and specific tariff rates under which agricultural imports for almost all products were prohibitive (table 19).

Since 1995, tariff transparency in Ukraine has significantly decreased as most ad valorem rates were replaced by specific or combined tariffs (see table 19). Other things equal, ad valorem tariffs are in general more transparent and less trade distorting than specific tariffs (OECD, 2001b). Ad valorem duties are calculated as a constant proportion of the value of duty of the imported good, where specific tariffs are expressed as a fixed monetary amount per physical unit of weight of the product imported, so that the associated degree of protection is dependent on the import price and can change independently of the rate itself. "When world prices decline, specific tariffs provide more protection proportionately than ad valorem tariffs and vice versa. Specific tariffs are more regressive and tend to distort domestic production patterns more than ad valorem tariffs because the level of protection depends on the value of the product. Further, specific tariffs may conceal high ad valorem equivalents as the estimation of average tariff level is cumbersome, thereby making real protection level estimation is very difficult" (OECD, 2001b: 24).

In Ukraine tariff rates are high and domestically produced products are usually more protected. For many products, the tariff rate ranges from 30 to 50\%. During 19952000 average agricultural import tariffs were much higher than total trade weighted import tariffs (table 14), and the share of the import of agricultural and food products in total merchandise imports equalled to around 6\% (see table 12). Although the rate of intra-industry trade in Ukraine is not very high in all sectors (QUAISSER, 1999), GOLOVEN (2001) states that the rates of the intra-industry trade in the agriculture and food processing industry are among the lowest in the Ukrainian economy. According to the total Grubel-Lloyd index, that measures the rate of intra-industry trade, being 0.085 in 2000 , this index in agriculture and food sector equalled to 0.030 and 0.063 respectively. The most importable agri-food products to Ukraine were cocoa and coca products, sugar, palm oil, food mixes, and tobacco.

The economic losses associated with a country's tariff structure depend not only on the average tariff rates, but also on the variance in these rates across products within a country. "For a given overall tariff average, the greater the dispersion in tariff rates, the greater the likelihood that consumers' and producers' decisions are distorted by the tariff structure" (OECD, 2001b: 24). A low average tariff rate could thus disguise significant economic and trade distortions if the dispersion of tariff rates is high. Dispersion also provides an indication of the complexity of a country's tariff schedule. Dispersion of tariffs could be measured as the proportion of items for which the tariff rate exceeds a reference level. In case of Ukraine, this reference level is the average agricultural import tariff rate of $26 \%$ (table 19), and the tariffs, which exceed that level, are called 'domestic spikes'. "International spikes' are customarily defined as those tariffs which exceed $15 \%$. The greater the proportion of 'spikes' in a country's tariff schedule, the greater the potential economic distortion" (OECD, 2001b: 25). From the data presented in table 19, it is clear that the most of Ukraine's tariffs exceed 'domestic' and 'international' reference levels, emphasising the complexity and distortive nature of trade protection in the country. 
Table 19: Import MFN tariff rates for major agri-food products in Ukraine

\begin{tabular}{|c|c|c|c|c|c|c|c|}
\hline & 1995 & 1996 & 1997 & 1998 & 1999 & 2000 & 2001 \\
\hline $\begin{array}{l}\text { Live animals } \\
01.01-01.06\end{array}$ & 5 & $\begin{array}{l}5-10, \text { but } \\
\text { less than } \\
0.04-0.1 \\
\text { ECU per } \\
\text { kg of live } \\
\text { weight }\end{array}$ & $\begin{array}{c}10-30, \text { but } \\
\text { not less } \\
\text { than } 0.2- \\
0.3 \mathrm{ECU} \\
\text { per kg of } \\
\text { live weight }\end{array}$ & $\begin{array}{l}10-30, \text { but } \\
\text { not less than } \\
0.2-1 \text { ECU } \\
\text { per kg of } \\
\text { live weight }\end{array}$ & $\begin{array}{c}\text { 10-30, but } \\
\text { not less } \\
\text { than } 0.2-1 \\
\text { ECU per kg } \\
\text { of live } \\
\text { weight }\end{array}$ & $\begin{array}{l}\text { 10-30, but not } \\
\text { less than } 0.2- \\
1 \text { ECU per kg } \\
\text { of live weight }\end{array}$ & $\begin{array}{c}0.2-0.3 € \\
\text { per кг of } \\
\text { live weight }\end{array}$ \\
\hline $\begin{array}{l}\text { Beef } 02.01- \\
02.02\end{array}$ & $15-20$ & $\begin{array}{l}20-30, \text { but } \\
\text { not less } \\
\text { than } 0.25- \\
0.4 \mathrm{ECU} \\
\text { per kg }\end{array}$ & $\begin{array}{l}\text { 30, but not } \\
\text { less than } \\
0.5-1 \mathrm{ECU} \\
\text { per kg }\end{array}$ & $\begin{array}{l}\text { 30, but not } \\
\text { less than } \\
0.5-1 \mathrm{ECU} \\
\text { per kg }\end{array}$ & $\begin{array}{l}\text { 30, but not } \\
\text { less than } \\
0.5-1 \mathrm{ECU} \\
\text { per kg }\end{array}$ & $\begin{array}{l}30, \text { but not } \\
\text { less than } 0.5- \\
1 \text { ECU per kg }\end{array}$ & $1 €$ per kg \\
\hline Pork 02.03 & 20 & $\begin{array}{l}\text { 30, but not } \\
\text { less than } \\
0.5 \mathrm{ECU} \\
\text { per kg }\end{array}$ & $\begin{array}{l}\text { 30, but not } \\
\text { less than } 1 \\
\text { ECU per } \\
\text { kg }\end{array}$ & $\begin{array}{l}30 \text {, but not } \\
\text { less than } 1 \\
\text { ECU per kg }\end{array}$ & $\begin{array}{l}30 \text {, but not } \\
\text { less than } 1 \\
\text { ECU per kg }\end{array}$ & $\begin{array}{l}30, \text { but not } \\
\text { less than } 1 \\
\text { ECU per kg }\end{array}$ & $1 €$ per kg \\
\hline $\begin{array}{l}\text { Sunflower } \\
\text { seeds } 12.06\end{array}$ & 2 & $\begin{array}{l}2, \text { but not } \\
\text { less than } \\
0.01 \mathrm{ECU} \\
\text { per kg }\end{array}$ & $\begin{array}{l}50, \text { but not } \\
\text { less than } \\
0.5 \mathrm{ECU} \\
\text { per kg }\end{array}$ & $\begin{array}{l}50, \text { but not } \\
\text { less than } 0.5 \\
\text { ECU per kg }\end{array}$ & $\begin{array}{l}50, \text { but not } \\
\text { less than } \\
0.5 \mathrm{ECU} \\
\text { per kg }\end{array}$ & $\begin{array}{l}50 \text {, but not } \\
\text { less than } 0.5 \\
\text { ECU per kg }\end{array}$ & $0.5 €$ per kg \\
\hline Wheat 10.01 & 10 & $\begin{array}{l}15 \text {, but not } \\
\text { less than } \\
40 \mathrm{ECU} \\
\text { per ton }\end{array}$ & $\begin{array}{l}15-30, \text { but } \\
\text { not less } \\
\text { than } 40 \\
\text { ECU per } \\
\text { ton }\end{array}$ & $\begin{array}{l}10-30, \text { but } \\
\text { not less than } \\
40 \text { ECU per } \\
\text { ton }\end{array}$ & $\begin{array}{l}10, \text { but not } \\
\text { less than } 40 \\
\text { ECU per } \\
\text { ton }\end{array}$ & $\begin{array}{l}10, \text { but not } \\
\text { less than } 40 \\
\text { ECU per ton }\end{array}$ & $40 €$ per ton \\
\hline Barley 10.03 & 10 & $\begin{array}{l}20 \text {, but not } \\
\text { less than } \\
0.01 \text { per } \mathrm{kg}\end{array}$ & $\begin{array}{l}10-30, \text { but } \\
\text { not less } \\
\text { than } 20 \\
\text { ECU per } \\
\text { ton }\end{array}$ & $\begin{array}{l}30 \text {, but not } \\
\text { less than } 20 \\
\text { ECU per ton }\end{array}$ & $\begin{array}{l}30, \text { but not } \\
\text { less than } 20 \\
\text { ECU per } \\
\text { ton }\end{array}$ & $\begin{array}{l}30 \text {, but not } \\
\text { less than } 20 \\
\text { ECU per ton }\end{array}$ & $20 €$ per ton \\
\hline Corn 10.05 & 10 & $\begin{array}{l}10 \text {, but not } \\
\text { less than } \\
0.01 \mathrm{ECU} \\
\text { per kg }\end{array}$ & $\begin{array}{l}\text { 10-30, but } \\
\text { not less } \\
\text { than } 20 \\
\text { ECU per } \\
\text { ton }\end{array}$ & $\begin{array}{l}30 \text {, but not } \\
\text { less than } 20 \\
\text { ECU per ton }\end{array}$ & $\begin{array}{l}\text { 30, but not } \\
\text { less than } 20 \\
\text { ECU per } \\
\text { ton }\end{array}$ & $\begin{array}{l}30 \text {, but not } \\
\text { less than } 20 \\
\text { ECU per ton }\end{array}$ & 0 \\
\hline $\begin{array}{l}\text { Vegetables } \\
07.01-07.09\end{array}$ & 10 & $\begin{array}{l}\text { Potatoes } \\
50 \% \text {, but } \\
\text { no less } \\
\text { than } 0.6 \\
\text { ECU per } \\
\text { kg }\end{array}$ & $\begin{array}{l}0,1-0,3 \\
\text { ECU per } \\
\quad \mathrm{kg}\end{array}$ & $\begin{array}{l}\text { 30-50, but } \\
\text { no less than } \\
0.1-0.3 \mathrm{ECU} \\
\text { per kg }\end{array}$ & $\begin{array}{c}30-50 \text {, but } \\
\text { no less than } \\
0.1-0.3 \\
\text { ECU per kg }\end{array}$ & $\begin{array}{l}30-50 \text {, but no } \\
\text { less than } 0.1- \\
0.3 \text { ECU per } \\
\text { kg }\end{array}$ & $\begin{array}{c}0.2-0.3 € \\
\text { per } \mathrm{kg}\end{array}$ \\
\hline $\begin{array}{l}\text { Vegetables } \\
\text { cut, and dried } \\
07.12-07.13\end{array}$ & 10 & 10 & 10 & $\begin{array}{l}30, \text { but no } \\
\text { less than } 0.6 \\
\text { ECU per kg }\end{array}$ & $\begin{array}{l}\text { 30, but no } \\
\text { less than } \\
0.6 \mathrm{ECU} \\
\text { per kg }\end{array}$ & $\begin{array}{l}30 \text {, but no } \\
\text { less than } 0.6 \\
\text { ECU per } \mathrm{kg}\end{array}$ & $0.6 €$ per kg \\
\hline $\begin{array}{l}\text { Nuts, citrus } \\
\text { and wine } \\
\text { grapes } 08.01- \\
08.05\end{array}$ & 10 & 10 & $\begin{array}{l}0.1-0.3 \\
\text { ECU per } \\
\text { kg }\end{array}$ & $\begin{array}{l}20-30, \text { but } \\
\text { no less than } \\
0.1-0.3 \mathrm{ECU} \\
\text { per kg }\end{array}$ & $\begin{array}{c}20-30, \text { but } \\
\text { no less than } \\
0.1-0.3 \\
\text { ECU per kg }\end{array}$ & $\begin{array}{l}\text { 20-30, but no } \\
\text { less than } 0.1- \\
0.3 \text { ECU per } \\
\text { kg }\end{array}$ & $\begin{array}{c}0.1-0.3 € \\
\text { per } \mathrm{kg}\end{array}$ \\
\hline $\begin{array}{l}\text { Apples, } \\
\text { cherry, } \\
\text { pineapples } \\
08.08\end{array}$ & 10 & 10 & $\begin{array}{c}0,5 \mathrm{ECU} \\
\text { per kg }\end{array}$ & $\begin{array}{l}30, \text { but no } \\
\text { less than } 0.5 \\
\text { ECU per } \mathrm{kg}\end{array}$ & $\begin{array}{l}\text { 30, but no } \\
\text { less than } \\
0.5 \mathrm{ECU} \\
\text { per kg }\end{array}$ & $\begin{array}{l}30, \text { but no } \\
\text { less than } 0.5 \\
\text { ECU per kg }\end{array}$ & $0.5 €$ per $\mathrm{kg}$ \\
\hline Kiwi, banana & 0 & 0 & 30 , but no & 30 , but no & 30 , but no & 30 , but no & 30 , but not \\
\hline
\end{tabular}




\begin{tabular}{|c|c|c|c|c|c|c|c|}
\hline $\begin{array}{l}\text { and exotic } \\
\text { fruits } 08.10\end{array}$ & & & $\begin{array}{l}\text { less than } \\
0.6 \mathrm{ECU} \\
\text { per kg }\end{array}$ & $\begin{array}{l}\text { less than } 0.6 \\
\text { ECU per } \mathrm{kg}\end{array}$ & $\begin{array}{l}\text { less than } \\
0.6 \mathrm{ECU} \\
\text { per kg }\end{array}$ & $\begin{array}{l}\text { less than } 0.6 \\
\text { ECU per kg }\end{array}$ & $\begin{array}{c}\text { less than } \\
0.6 € \text { per } \mathrm{kg}\end{array}$ \\
\hline $\begin{array}{l}\text { Non- } \\
\text { concentrated } \\
\text { milk } 04.01\end{array}$ & 5 & $\begin{array}{l}20, \text { but no } \\
\text { less than } \\
0.1 \text { ECU } \\
\text { per litre }\end{array}$ & $\begin{array}{l}20 \text {, but no } \\
\text { less than } \\
0.1 \text { ECU } \\
\text { per litre }\end{array}$ & $\begin{array}{l}\text { 20, but no } \\
\text { less than } 0.1 \\
\text { ECU per } \\
\text { litre }\end{array}$ & $\begin{array}{l}20, \text { but no } \\
\text { less than } \\
0.1 \text { ECU } \\
\text { per litre }\end{array}$ & $\begin{array}{l}20 \text {, but no } \\
\text { less than } 0.1 \\
\text { ECU per litre }\end{array}$ & $\begin{array}{l}0.1 € \text { per } \\
\text { litre }\end{array}$ \\
\hline $\begin{array}{l}\text { Concentrated } \\
\text { milk, yoghurt, } \\
\text { cheese } 04.02 \text {, } \\
04.03,04.06\end{array}$ & 5 & $\begin{array}{c}30,20, \text { but } \\
\text { no less } \\
\text { than } 0.4- \\
0.45 \text { ECU } \\
\text { per litre }\end{array}$ & $\begin{array}{c}0.5-0.8 \\
\text { ECU per } \\
\text { litre }\end{array}$ & $\begin{array}{c}0.5-0.8 \mathrm{ECU} \\
\text { per litre }\end{array}$ & $\begin{array}{c}0.5-0.8 \\
\text { ECU per } \\
\text { litre }\end{array}$ & $\begin{array}{c}0.5-0.8 \text { ECU } \\
\text { per litre }\end{array}$ & $\begin{array}{c}0.5-0.8 € \\
\text { per litre }\end{array}$ \\
\hline Butter 04.05 & 5 & 5 & $\begin{array}{l}50, \text { but no } \\
\text { less than } \\
1.5 \mathrm{ECU} \\
\text { per kg }\end{array}$ & $\begin{array}{l}50, \text { but no } \\
\text { less than } 1.5 \\
\text { ECU per kg }\end{array}$ & $\begin{array}{l}50, \text { but no } \\
\text { less than } \\
1.5 \mathrm{ECU} \\
\text { per kg }\end{array}$ & $\begin{array}{l}50, \text { but no } \\
\text { less than } 1.5 \\
\text { ECU per kg }\end{array}$ & $1.5 €$ per kg \\
\hline $\begin{array}{l}\text { Sugar } 17.01- \\
17.02\end{array}$ & $10-30$ & $\begin{array}{c}10-30,50, \\
\text { but no less } \\
\text { than } 0.2- \\
0.3 \mathrm{ECU} \\
\text { per kg }\end{array}$ & $\begin{array}{c}30-50, \text { but } \\
\text { no less } \\
\text { than } 0.3 \\
\text { ECU per } \\
\text { kg }\end{array}$ & $\begin{array}{l}50, \text { but no } \\
\text { less than } 0.3 \\
\text { ECU per } \mathrm{kg}\end{array}$ & $\begin{array}{l}50, \text { but no } \\
\text { less than } \\
0.3 \mathrm{ECU} \\
\text { per kg }\end{array}$ & $\begin{array}{l}50, \text { but no } \\
\text { less than } 0.3 \\
\text { ECU per kg }\end{array}$ & $\begin{array}{l}50, \text { but not } \\
\text { less than } 1 \\
€ \text { per kg }\end{array}$ \\
\hline $\begin{array}{l}\text { Confectionery } \\
17.04\end{array}$ & 10 & $\begin{array}{l}\text { 30, but no } \\
\text { less than } 1 \\
\text { ECU per } \\
\text { kg }\end{array}$ & $\begin{array}{l}\text { 30, but no } \\
\text { less than } 1 \\
\text { ECU per } \\
\text { kg }\end{array}$ & $\begin{array}{l}30, \text { but no } \\
\text { less than } 1 \\
\text { ECU per kg }\end{array}$ & $\begin{array}{l}30, \text { but no } \\
\text { less than } 1 \\
\text { ECU per kg }\end{array}$ & $\begin{array}{l}30, \text { but no } \\
\text { less than } 1 \\
\text { ECU per kg }\end{array}$ & $1 €$ per kg \\
\hline $\begin{array}{l}\text { Flour 11.01- } \\
11.02\end{array}$ & 10 & $\begin{array}{l}20, \text { but no } \\
\text { less than } \\
0.03-0.04 \\
\text { ECU per } \\
\text { kg }\end{array}$ & $\begin{array}{c}20-30, \text { but } \\
\text { no less } \\
\text { than } 0.1 \\
\text { ECU per } \\
\text { kg }\end{array}$ & $\begin{array}{l}30, \text { but no } \\
\text { less than } 0.1 \\
\text { ECU per } \mathrm{kg}\end{array}$ & $\begin{array}{l}\text { 30, but no } \\
\text { less than } \\
0.1 \mathrm{ECU} \\
\text { per kg }\end{array}$ & $\begin{array}{l}30, \text { but no } \\
\text { less than } 0.1 \\
\text { ECU per kg }\end{array}$ & $0.1 €$ per kg \\
\hline $\begin{array}{l}\text { Corn oil } \\
15.15 .21\end{array}$ & 10 & 10 & 10 & $\begin{array}{l}50, \text { but no } \\
\text { less than } 0.8 \\
\text { ECU per } \mathrm{kg}\end{array}$ & $\begin{array}{l}50, \text { but no } \\
\text { less than } \\
0.1 \text { ECU } \\
\text { per kg }\end{array}$ & $\begin{array}{l}50, \text { but no } \\
\text { less than } 0.1 \\
\text { ECU per kg }\end{array}$ & $0.8 €$ per $\mathrm{kg}$ \\
\hline $\begin{array}{l}\text { Palm and coco } \\
\text { oil } 15.11 \text {, } \\
15.13\end{array}$ & 10 & 0 & 0 & 0 & 0 & 0 & 0 \\
\hline $\begin{array}{l}\text { Rape seed oil } \\
15.14\end{array}$ & 10 & 10 & 10 & $\begin{array}{l}\text { 30, but no } \\
\text { less than } \\
0.15 \mathrm{ECU} \\
\text { per kg }\end{array}$ & $\begin{array}{l}30, \text { but no } \\
\text { less than } \\
0.15 \mathrm{ECU} \\
\text { per kg }\end{array}$ & $\begin{array}{l}\text { 30, but no } \\
\text { less than } 0.15 \\
\text { ECU per kg }\end{array}$ & 5 \\
\hline $\begin{array}{l}\text { Sunflower oil } \\
15.12\end{array}$ & 10 & 10 & 10 & $\begin{array}{l}50, \text { but no } \\
\text { less than } 0.8 \\
\text { ECU per kg }\end{array}$ & $\begin{array}{l}50, \text { but no } \\
\text { less than } \\
0.8 \mathrm{ECU} \\
\text { per kg }\end{array}$ & $\begin{array}{l}50, \text { but no } \\
\text { less than } 0.8 \\
\text { ECU per kg }\end{array}$ & $0.8 €$ per $\mathrm{kg}$ \\
\hline
\end{tabular}

Source: $\quad$ LADYGINA (1998) and UNIFIED CUSTOMS TARIFFS (2001).

Moreover, since 1998, Ukraine has been using seasonal tariffs. ${ }^{36}$ They are twice as high as MFN rates during 2-4 months after harvest. These tariffs are used for vegetables,

\footnotetext{
36 The Law of Ukraine "On State Regulations of Agricultural Imports to Ukraine” from July 17, 1997 manages the seasonal tariffs.
} 
fruits, grain, and sunflower seeds. They further distort price signals from world markets and decrease the predictability of the price developments.

Finally, the tariff rate schedule in Ukraine is characterised by the tariff escalation. "Tariff escalation occurs when the tariff applied on a product "chain" rises as goods undergo further processing, resulting in a higher effective protection for the processed industry than otherwise would be the case. It thus produces a bias against processed goods and creates impediments to imports of higher value-added" (OECD, 2001b: 27). Tariff escalation in Ukraine is presented for several production chains (table 20).

Table 20: Tariff escalation in Ukraine

\begin{tabular}{|c|c|c|c|}
\hline & Raw product & Semi-final product & Final product \\
\hline \multirow[t]{2}{*}{ 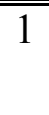 } & Live cattle & Beef and pork & Meat products \\
\hline & $0.2-0.3 €$ per $\mathrm{kg}$ & $1 €$ per kg & $30 \%$, but not less than $0.8 €$ \\
\hline \multirow[t]{2}{*}{2} & Grain & Flour & Flour products \\
\hline & $0.02-0.04 €$ per $\mathrm{kg}$ & $0.1 €$ per $\mathrm{kg}$ & $30 \%$, but not less than $0.5 €$ \\
\hline \multirow[t]{2}{*}{3} & Sugar beet & Sugar & Confectionery \\
\hline & $30 \%$, but not less $0.15 €$ per & $50 \%$, but not less than $1 €$ & $1 €$ per kg \\
\hline \multirow[t]{2}{*}{4} & Vegetables & Dried and cut vegetables & Canned vegetables \\
\hline & $0.2-0.3 €$ per $\mathrm{kg}$ & $0.6 €$ per $\mathrm{kg}$ & $1 €$ per kg \\
\hline \multirow[t]{2}{*}{5} & Raw milk & Concentrated milk & Butter \\
\hline & $0.1 €$ per litre & $0.5-0.8 €$ per litre & $1.5 €$ per $\mathrm{kg}$ \\
\hline
\end{tabular}

Source: $\quad$ Own calculations based on table 19.

\subsubsection{Tariff-rate quotas and other non-tariff barriers}

Ukraine does not use tariff rate quotas on the permanent basis. As a rule, such quotas are opened because of the pressure of the food processing industry's lobby, while farmers oppose them being afraid of agricultural price decrease. These different interests significantly prolong policy debates and the introduction of the quotas and their administration. Transparency is lacking both during preparing and implementing the quota regulation. Since 1998, the tariff rate quotas for sugar, barley and wheat were opened temporarily. In-quota tariff rates were set at zero or at very low level, while overquota rates reached $30-50 \%{ }^{37}$ STRIEWE (2001) argues that the quotas for sugar and wheat in Ukraine did not result in domestic price reduction and the only explanation could be that importers who had access to these quotas colluded not to fill the quotas, and thus, not to allow price decrease so as to maximise their quota rents. The GOU has lost budget revenue and funds allocated to quota administration. "The quota rent from privileged raw sugar import in 2000 is estimated to be $\$ 28 \mathrm{mln}$ and for wheat import within the range from $\$ 5.5$ to $\$ 12.5 \mathrm{mln} "$ (STRIEWE, 2001: 140).

Ukraine uses many non-tariff barriers with the purpose to limit imports. Most of these barriers are applied to all products, and not to specifically agricultural ones (see MOVCHAN, 2002 and section 3.1.4). Import clearing procedures are prohibitive and nontransparent due to the frequent retroactive changes (MICHAELY, 1999). This is a special

${ }^{37}$ See STRIEWE (2001) for detailed analysis of the tariff rate quotas in Ukraine. 
issue of concern for the importers of agricultural machinery, for example. Before March 2000, the minimum customs value system for almost all the agricultural and food products were used to limit legal imports by overpricing their real value. The abolishment of this procedure greatly liberalised Ukraine's trade policy.

Currently the main non-tariff barrier for agriculture is working through inconsistent and non-transparent application of the sanitary and phytosanitary measures. Ukraine is not member of the WTO. Since none of Ukraine's agencies has signed agreements with any of three international organisations that are identified in the WTO Sanitary and Phytosanitary Agreement, the certification documents from other countries are usually not valid to clear import to Ukraine. "Many traders state that Ukraine applies a range of measures which are not based on science or supported by risk assessment, and which differ substantially from international standards" (VON CRAMON-TAUBADEL and ZORYA, 2000: 15). Such not-tariff measures greatly distort price signals from the world markets.

\subsubsection{Farm-gate prices in Ukraine}

As a result of the above-described trade policy, the farm-gate prices in Ukraine were significantly distorted during the observed period. In the Soviet Union, central planning authorities sent price signals to the farmers. Along with prices, the authorities also determined output plans. Therefore, prices did not play the same allocative role as in the market economy. As Ukraine gave up the command-administrative system, price signals would have become leading indicators, on which production and investment decisions were made. Prices reflect the scarcity of factors of production and, consequently, the incomes flowing into each factor. To make the agricultural sector efficient, farmers should orient their production according to world market prices and adjust their decisions to the changes of these prices. If the price signals are distorted, farmers make their decisions based on unsustainable price relations. If once domestic price ratios were to be corrected, many farmers could find themselves in difficult situation.

The below price analysis is conducted by estimating the nominal rate of protection (NPR), the effective rates of protection (EPR), and the cross-product relative prices. ${ }^{38}$ The equations of the NPR were mentioned in section 2.3.3, but here we re-write them. The nominal rate of protection (NPR) is estimated as

$$
N P R=\frac{P_{d}-P_{w}}{P_{w}}=P_{d} / P_{w}-1
$$

where $P_{d}$ is farm-gate (domestic) price for agricultural product; $P_{w}$ is its border price $\left(P_{b p}\right)$ converted into local currency at the official nominal exchange rate $E_{o}$ and adjusted for the "marketing costs":

$$
P_{w}=\left(P_{b p} * E_{o}^{U A H / \$}\right)-(\text { 'MarketingCosts' }) \Rightarrow \quad \text { Export situation }
$$

38 Note that the NPR and EPR will be further used in the section 4.1.2 to estimate the impact of the real exchange rate on the agricultural incentives in Ukraine. 


$$
P_{w}=\left(P_{b p} * E_{o}^{U A H / \$}\right)+\left(' M a r k e t i n g C o s t s^{\prime}\right) \Rightarrow \quad \text { Import situation }
$$

In the export situation, the 'marketing costs' refer to the costs of moving the agricultural product from the Ukrainian farm (field) to the export destination on the world market (usually to the FOB or DAF). In the import situation, the 'marketing costs' refer to the costs of moving the agricultural product from the world market (usually CIF point) to the domestic consumers. The equation (3.2), therefore, consists of four elements: (1) farm-gate price $P_{d}$; (2) world market (or border) price $P_{b p}$; (3) official nominal exchange rate $E_{o}$; and (4) 'marketing costs', which are deducted (or added in import situation) from the world market price to define the given world market price for domestic farmers for the agricultural product in question. The positive value of the NPR refers to the 'support' of the domestic farmers through higher domestic price in comparison with the world market prices. The negative value refers to the 'taxation' of the domestic agricultural producers.

The effective rate of protection (EPR) is estimated as

$$
E P R=\frac{V A_{d}-V A_{w}}{V A_{w}}=V A_{d} / V A_{w}-1=P_{d}^{P_{d}-\sum_{j} a_{l j} P_{j}^{i}} / P_{w}-\sum_{j} a_{l j} P_{j}^{w}-1
$$

where $V A d$ and $V A w$ are the value-added of the agricultural product at the farmgate level and world market prices correspondingly. The $a_{l j}$ are technical coefficients measuring the number of units of intermediate factor $j$ per unit of production of output $l$. The $P_{j}$ are the prices of the intermediate inputs, which form the variable costs of production. The EPR shows the impact of the agricultural policy not only on the agricultural output prices, but also on the agricultural input prices. The GOU could use different schemes to support farmers through cheapening the inputs or taxing them through introduction of the high import tariffs (and/or non-tariff barriers) on the import of the agricultural inputs (for instance, fuel or machinery). The EPR is, therefore, preferable to the NPR, as it considers the price situation in the both output and input markets.

The estimations of the NPR for Ukraine are presented in table 20. Ukraine is the net exporter of the all crops in question, except sugar beet since 1998. ${ }^{39}$ Thus, for an estimation of the world reference market prices $(P w)$, the equation (3.3) should be used. The official nominal exchange rate $\left(E_{o}\right)$ is the average annual official NBU exchange rate for UAH/\$ (UEPLAC, 2002). The export marketing costs for grain and sunflower seeds vary from $\$ 26$ to $\$ 30$ per ton (see detailed explanation of the marketing costs in STRIEWE and VON CRAMON-TAUBADEL, 1999; ZORYA, 2001b). The export marketing costs for sugar (sugar beet equivalent) is assumed to equal $\$ 25$ per ton in 1996-1997, and the import marketing costs are $\$ 10$ per ton.

The farm-gate and the world market (FOB, DAF, and CIF) prices are unweighted average prices for August-December reported by the STATE STATISTICS COMMITTEE OF UKRAINE (2001c), e.g. the months in which large output sales and sometimes exports are

\footnotetext{
${ }^{39}$ Due to the lack of the reliable information about livestock products, the data on crops is only presented.
} 
used to finance the autumn-seeding campaign. Moreover, as credit repayment to the state and the commercial banks dues on November-December for most farms, most sales take place in these particular months (see also ZORYA and VON CRAMON-TAUBADEL, 2002).

Table 21 shows that during 1996-1999, the grain prices were 10-15\% lower than world reference market prices. The taxation of the sunflower seeds was even higher, and after the introduction of the export tax in combination with relatively good harvest in 2001, the Ukrainian farm-gate price for seeds was $44 \%$ lower than the world market reference price. The sugar beet (sugar equivalent) prices were always higher than the world market prices since 1998 when Ukraine became a net importer. Even in the netexport years, Ukraine could export sugar only to the CIS countries, as its prices exceeded the world market level. In 2000, Ukraine imported around 700 thousand tons of wheat and the NPR jumped to $45 \%$. The low grain harvest of 2000 also resulted in the slightly higher prices than world market ones for feed wheat and feed barley. In 2001, Ukraine harvested a record $39 \mathrm{mln}$ ton of grain. The domestic prices fall down nearly to the world market price level, except food wheat. The prices for sunflower seeds rose sharply due to the low seed harvest and strong demand for oil seeds from domestic oil processing plants.

Table 21: Nominal rates of protection for selected agricultural products in Ukraine, 1996-2001 (in \%)

\begin{tabular}{lrrrrrr}
\hline & $\mathbf{1 9 9 6}$ & $\mathbf{1 9 9 7}$ & $\mathbf{1 9 9 8}$ & $\mathbf{1 9 9 9}$ & $\mathbf{2 0 0 0}$ & $\mathbf{2 0 0 1}$ \\
\hline \hline Winter food wheat & -9.4 & 1.8 & -8.2 & -4.6 & 45.2 & 16.4 \\
Winter feed wheat & -32.8 & -13.1 & -7.6 & -3.5 & 12.6 & 0 \\
Winter feed barley & -14.6 & -2.7 & -13.8 & -0.9 & 2.2 & 2.1 \\
Corn & -3.1 & -14.0 & 23.9 & 0.0 & -0.8 & -1.1 \\
Sunflower seeds & -25.2 & -27.2 & -31.6 & -16.2 & -44.2 & 23.1 \\
Sugar beet & 31.9 & 7.19 & 11.3 & 4.1 & 12.4 & 41.2 \\
\hline
\end{tabular}

Source: $\quad$ Own calculations based on UkrAgroConsult (2001-2003), STATE STATISTICAL COMmitTeE of Ukraine (2001d), and Zorya and vON Cramon-Taubadel (2002).

But one should note that these NPR coefficients should be treated with caution. First of all, Ukraine is a large country with poorly integrated markets. Furthermore, different prices are obtained from different marketing channels. This is especially important for the years of 1996-1999 when barter was intensively used and price dispersion was huge. "Finally, recall that the period from August to December - as the period of the highest output sales - is used to calculate average prices. If one compares these calculations with those for calendar or marketing years, the results could be quite different" (ZORYA and VON CRAMON-TAUBADEL, 2002: 5).

To estimate the effective rates of protection, the variable costs at the domestic and world market prices should be calculated first. The variable inputs include fertilisers, chemicals, seeds, and fuel. Domestic prices for these inputs are taken from the price lists of the private input suppliers and official statistics. ${ }^{40}$ For the observed period, the

\footnotetext{
${ }^{40}$ See Zorya and vON CRAMON-TAUBADEL (2002) for detailed list of sources of the data and the comparison of the costs at the domestic and world market prices. See also TARASEVYCH (1999) to compare the domestic and world market prices for agricultural inputs in Ukraine in 1997.
} 
technical coefficients $\left(a_{l j}\right)$ are represented by fixed coefficients and the data for Ukrainian agriculture on average is used (see ZORYA and VON CRAMON-TAUBADEL, 2002).

It seems that the domestic prices for agricultural chemicals equal the world market ones: Ukraine imports duty-free most chemical as they are not produced domestically. Moreover, according to BENECKE (2000), prices for agricultural chemicals in Ukraine closely correspond to the prices in Germany. A similar situation is with the fuel: fuel for agricultural producers during the observed period was imported from Russia duty-free and the domestic prices, therefore, could be said to equal the world reference prices.

"Seed prices greatly depend on the quality of seeding material and, hence, the uniform information on seed prices is not available. Seed varieties may quickly appear on the market and disappear just as quickly after showing worse results than other varieties" (ZORYA and VON CRAMON-TAUBADEL, 2002: 16). Although the import regime for seeds is rather complicated by the long and costly certification and test procedures, it is similarly difficult to estimate these costs for certain types of seeds. The import duties for most seeds are zero, except of seeds for barley (20\%) and sugar beet (70\%) introduced in 1999. Therefore, the internal seed prices are assumed to be equal to the world market prices, excluding barley and sugar beet during 1999-2001. And finally, the domestic prices for fertilisers are assumed to be $10 \%$ lower than the world market prices, as Ukraine is a net-exporter of the most fertilisers. The calculations of the EPR are summarised in table 21 .

The results of table 22 go along the above NPR estimations (table 21), but the rates of taxation and support are strengthened for almost all crops. The grain (except wheat) and sunflower seeds were effectively taxed during 1996-2000. In 2001, the sunflower producers were substantially 'protected', while grain producers generally 'enjoyed' slightly higher domestic value-added compared with the world market situation. Sugar-beet producers were effectively supported, and in 2001, for example, the domestic value-added exceeded the world reference level by $135 \%$.

Table 22: Effective rates of protection for selected agricultural products in Ukraine, 1996-2001 (in \%)

\begin{tabular}{lcccccc}
\hline & $\mathbf{1 9 9 6}$ & $\mathbf{1 9 9 7}$ & $\mathbf{1 9 9 8}$ & $\mathbf{1 9 9 9}$ & $\mathbf{2 0 0 0}$ & $\mathbf{2 0 0 1}$ \\
\hline \hline Winter food wheat & -13.8 & 2.0 & -12.6 & -8.7 & 57.5 & 34.3 \\
Winter feed wheat & -53.6 & -22.6 & -15.7 & -7.2 & 34.0 & 2.4 \\
Winter feed barley & -20.2 & -3.4 & -21.0 & -6.8 & -0.6 & 4.9 \\
Corn & -3.6 & -16.2 & 35.4 & 0.0 & -9.9 & 1.5 \\
Sunflower seeds & -34.9 & -37.5 & -45.5 & -24.6 & -59.0 & 38.6 \\
Sugar beet & 55.6 & 191.0 & 21.2 & 6.0 & 23.2 & 135.4 \\
\hline
\end{tabular}

Source: $\quad$ Own calculations based on UKRAGROCONSULT (2001-2003), STATE STATISTICAL

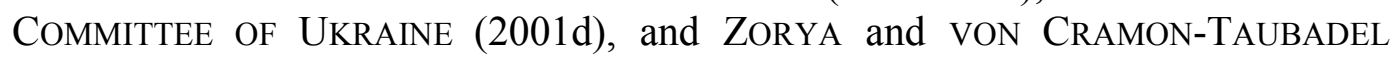
(2002).

Along with the differences between domestic and the world market prices, agricultural price ratios in Ukraine are distorted as well. In the Soviet Union, price ratios were shifted to the higher domestic livestock price and lower crop price ratios, while the variations of the price ratios in Ukraine compared with the price ratios on the world markets were considerable. In our case, price ratio calculations are based on ratios with the wheat prices - a chosen commodity price relative to the wheat price, divided by the 
same price ratios on the world market (a coefficient closer to 1 indicates less distortion). According to the WORLD BANK (1994), the coefficient of variation for sugar, sunflower seeds, eggs, milk, cattle, poultry, and hogs in 1987 equalled to $35 \%$ on average, fell by one-half in 1991 to $18 \%$, and then rose again to $24 \%$ in $1993 .{ }^{41}$ The recent price ratios are presented in table $23 .^{42}$

The price ratios in Ukraine during 1997-1999 did not mirror the world market price ratios. In 1998, for example, the domestic price ratios deviated from the world market ones by $51 \%$. In 2000 , the domestic price ratios seemed to stabilise and the deviations from the world market signals were only $4 \%$. Already in the short run the corrected price ratios positively affected the resource allocation and probably induced recent agricultural growth in 2000 and 2001. In the long run, the correct price ratios are the 'best gift' that the GOU can present to the farms to ensure their long-term sustainable successful performance.

\footnotetext{
${ }^{41}$ Coefficient of variation of $35 \%$, for example, means that the domestic price ratios in Ukraine deviates by $35 \%$ with the correspondent price ratios on the world agricultural markets.

${ }^{42}$ It is true that the 'world market prices' are distorted as well, as they reflect the government interventions all over the world, especially in the OECD countries. But for Ukraine these prices are exogenously given and they mirror the opportunity costs to produce domestically.
} 
Table 23: Distortion in domestic producer price ratios for selected agricultural products in Ukraine (in terms of wheat prices) compared to those on the world market, 1997-2000

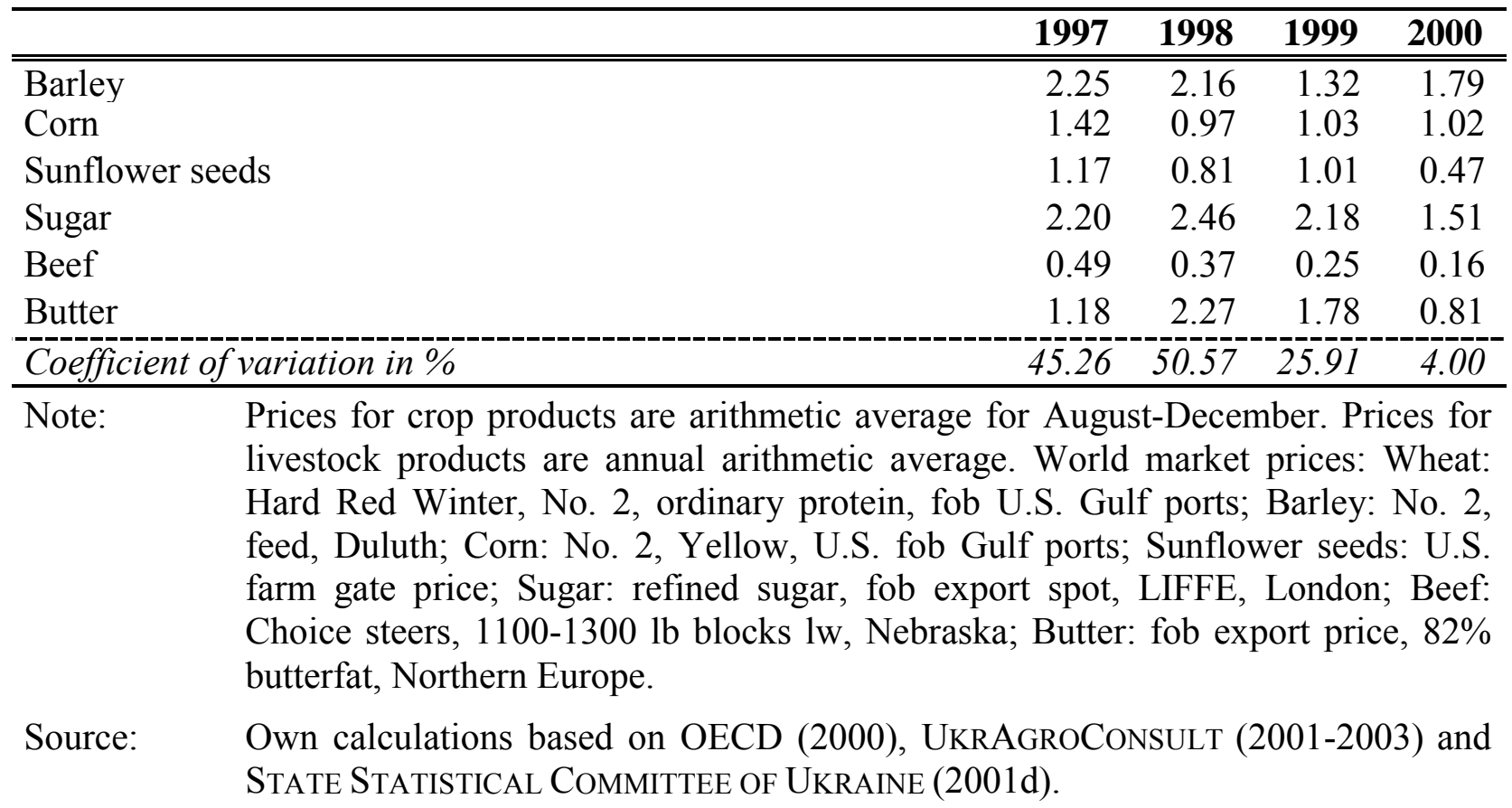




\subsection{Summary of the chapter}

The general economic and agricultural performance in Ukraine during the last decade can be clearly divided into two distinct periods. During the first period (19911999), the loose fiscal policy, inconsistent exchange rate regime, slow structural reforms, and inward-oriented foreign policy ensured the dramatic fall of the country's GDP. Although at the outset of transition, all CEE transition economies experienced a GDP decline, its magnitude and length was much lower and shorter than in Ukraine. Agricultural output followed a falling path of total GDP. Greatly-distorted initial conditions from the Soviet time, soft budget constraints for the farms, distortive farm support, as well as import protection combined with the export discouragement caused the severe agricultural contraction. This period of agricultural development can be hardly called a period of so-called 'creative destruction' (see SWINNEN, 2001), but rather a period of government failures and lost opportunities. Playing a very important role in the overall economy, agricultural decline certainly contributed to the fall of national GDP as well.

In contrast, the second period (end of 1999-2001) is characterised by economic reforms in the fiscal sphere, agricultural and energy sectors, as well as better performance of the floating exchange rate regime. The financial crisis in 1998 opened a new 'window of opportunity' for Ukrainian policy makers and Ukrainian economy, and it seems that this window was successfully used to the certain extent. For the first time since obtaining Independence, Ukrainian agriculture enjoyed macroeconomic stability, high agricultural prices, less distortive farm support, and hard budget constraints. Farmers quickly reacted to positive incentives created by the economic reforms and from this success benefited the overall economy. The use of the substantial internal reserves will allow many Ukrainian farmers to operate successfully in foreseeable future, but already in the medium run more reforms are urgently needed to modernise the agriculture and to sustain farm competitiveness. 


\section{Empirical Estimations of Interdependencies between Agriculture and Macroeconomics in Ukraine}

In this chapter the theoretical foundations of interlinkages between agriculture and macroeconomies and analysis of Ukrainian economy in transition are used to quantify and/or empirically describe the impact of the real exchange and interest rates on agriculture in Ukraine on the one hand, and the effects of agriculture on the rest of the economy on the other. This chapter begins with the estimation of the effects of the RER misalignment on agricultural incentives and agricultural growth in Ukraine over 19962001 .

\subsection{Real exchange rate and agriculture in Ukraine}

To assess the impact of the RER misalignment on agriculture in Ukraine, the equilibrium RER (ERER) is estimated with the help of the Edwards model. The ERER assessment will allow the construction of the misalignment index to determine its impact on agriculture.

\subsubsection{Equilibrium real exchange rate in Ukraine}

\subsubsection{Edwards model of equilibrium real exchange rate}

Modern discussions on macroeconomic policy and economic growth in a small open economy are unimaginable without consideration of the RER and its equilibrium dynamics. The equilibrium real exchange rate is sometimes called an 'ideal' exchange rate (see RAZIN and COLLINS, 1997), i.e. the exchange rate that is compatible with internal and external balance.

Well-known approach to measure the ERER is the Purchasing Power Parity (PPP). It is actively used to estimate the equilibrium state of the RER in developed economies (FROOT and ROGOFF, 1995; ROGOFF, 1996). However, because of many weaknesses it is rarely used in the context of transition as well as developing countries (EDWARDS, 2000). The problem is that a hallmark of the PPP approach to equilibrium exchange rates is the choice of a single equilibrium rate for all periods, without reference to movements in the fundamentals (see BAFFES et al., 1999 with detailed arguments against PPP approach). With such structural changes taken place in Ukraine over a last decade, it is impossible to set a certain single value of the RER and call it 'sustainable'.

Early estimations of the ERER in the CEE transition economies were based on calculations of the equilibrium or sustainable U.S. dollar wage (HALPERN and WYPLOSZ, 1996; KRAJNYAK and ZETTELMEYER, 1997). The key interest of these studies was to explain the RER developments over the different periods of transition, and qualify the RER appreciation in later periods in particular. More recent studies emphasise the importance of Ballasa-Samuelson effect to distinguish between RER overvaluation and RER appreciation due to the productivity improvements (DE BROECK and SLOK, 2001; HALPERN and WyPLOSZ, 2001; EGERT, 2002). The ERER is also started to be estimated 
by using the Natural Real Exchange Model, as, for example, for Czech Republic (see, for example, FrAIT and KOMAREK, 2001).

While all these studies foresee to explain the effects of structural changes on the RER in the CEE transition economies, the key interest of this dissertation is to discuss distinct effects of various policies on the RER. This study is even not so concerned with the calculation of the equilibrium path of the RER per se, as with the demonstration of an importance of sound macroeconomic and structural policies for sustainable economic development in Ukraine. In this respect, so-called EDWARDS model suits very well. This choice is also supported by the fact that it is extensively used to determine the impact of various macroeconomic policies on the exchange rate in the emerging economies (EDWARDS, 1989; BAFFES et al., 1999; EDWARDS and SAVASTANO, 1999).

The model is presented as a reduced-form equation of the RER which is used to calculate the ERER by excluding the effects of transitory variables. The ERER is defined as that RER which results in the simultaneous attainment of internal and external equilibrium for given values of the relevant economic fundamentals explaining the RER. Based on this description, the EDWARDS model combines the elements of popular Fundamental Equilibrium Exchange Rate (FEER) and the Behaviour Equilibrium Exchange Rate (BEER) approaches (CLARK and MACDONALD, 1998). The FEER approach was developed by WILLIAMSON (1994), and it calculates "the real exchange rate that is consistent with the economy operating at capacity output and a sustainable current account position" (CLARK and MACDONALD, 2000: 3). The BEER approach "produces a measure of misalignment that is different from the FEER, as it relates to the deviation between the actual exchange rate and the value given by the estimated equilibrium relationship between the real exchange rate and economic fundamentals" (CLARK and MACDONALD, 2000: 3).

In the following, the short version of the EDWARDS model is presented which is largely based on philosophy of the DEM from section 2.3.2 (see EDWARDS, 1994). The model considers three-goods: exportables, importables, and non-tradables in a small open economy. It is assumed that such a country produces the exportable $(X)$ and non-tradable $(N)$ goods, and it consumes the importable $(M)$ and non-tradable $(N)$ goods. Nationals of the country hold both foreign $(F)$ and domestic $(M)$ money. In the short run the government can borrow abroad, but in the long run it is assumed that the government expenditures are fully financed through taxes. The prices for exportable $\left(P^{*}{ }_{X}\right)$ and importable $\left(P^{*}{ }_{M}\right)$ goods are exogenously given for this small country and the import tariff $(\pi)$ is set. It is assumed that the price of exportables in terms of foreign currency is fixed and is equal to unity $\left(P^{*}=1\right)$.

The nationals hold the following money portfolio:

$$
A=M+E F
$$

where $A$ is total nominal assets, consisting of domestic $(M)$ and foreign money $(F)$ times the nominal exchange rate $(E)$. The real assets $(a)$ in terms of exportable goods are defined as

$$
a=A / E=M / E+F
$$


The demand side of the model identifies the demand for importable and nontradable goods (equation 4.3):

$$
\begin{aligned}
& D_{M}=D_{M}\left(e_{M}, a\right), \frac{\partial D_{M}}{\partial e_{M}}<0, \frac{\partial D_{M}}{\partial a}>0 \\
& D_{N}=D_{N}\left(e_{M}, a\right), \frac{\partial D_{N}}{\partial e_{M}}<0, \frac{\partial D_{N}}{\partial a}>0 \\
& \text { where } e_{M}=P_{M} / P_{N}=\left[E P_{M}^{*}+\pi\right] / P_{N}, \pi \text { is the import tariff, } P_{M} \text { is the domestic }
\end{aligned}
$$
price of importables, $P^{*}{ }_{M}$ is the foreign price of importables, $P_{N}$ is the price of the nontradables. goods:

The supply side shows the supply functions of the exportable and non-tradable

$$
\begin{aligned}
& \quad S_{X}=S_{X}\left(e_{X}\right), \frac{\partial S_{X}}{\partial e_{X}}>0 \text { and } S_{N}=S_{N}\left(e_{X}\right), \frac{\partial S_{N}}{\partial e_{X}}<0 \\
& \text { where } e_{X}=E / P_{N} .
\end{aligned}
$$

The government sector consumes both importables and non-tradables and finances its expenditures through non-distortionary taxes $(t)$ or domestic credit $\triangle D C$ :

$$
\begin{aligned}
& G=P_{N} G_{N}+E P_{M}^{*} G_{M} \\
& G=t+\Delta D C
\end{aligned}
$$

Finally, the external sector is presented through the current account equation:

$$
\begin{aligned}
& C A=S_{X}\left(e_{X}\right)-P_{M}^{*} D_{M}\left(e_{M}, a\right)-P_{M}^{*} G_{M} \\
& C A=\Delta R \text { and } \Delta M=\Delta D C+E \Delta R \\
& e=\alpha e_{M}^{*}+[1-\alpha] e_{X}=\frac{E\left[\alpha P_{M}^{*}+[1-\alpha] P_{X}^{*}\right]}{P_{N}}
\end{aligned}
$$

Equation (4.7) determines the current account as a difference between export supply and import consumed by private and government sectors. The current account also equals the changes in foreign reserves $(\Delta R)$ expressed in the foreign currency, though in the short run the current account can be financed through capital inflows. Equation (4.8) presents the link between changes in international reserves, domestic credit and domestic stock of money. Finally, the model is closed by the real exchange rate $(e)$, which is defined as the relative price of tradables to non-tradables.

Long-run sustainable equilibrium is attained when the non-tradable goods market and the external sector are simultaneously in equilibrium. A steady-state is attained when the following four conditions hold simultaneously: (1) the non-tradables market clears; 
(2) the external sector is in equilibrium: $\Delta R=C A=\Delta M$; (3) fiscal policy is sustainable: $G$ $=t$; and (4) portfolio equilibrium is preserved. "The real exchange rate prevailing under these steady-state conditions is the long-run equilibrium real exchange rate" (EDWARDS, 1994: 65-66).

The market for non-tradable goods clears when

$$
D_{N}\left(e_{M}, a\right)+G_{N}=S_{N}\left(e_{X}\right)
$$

where the $G_{N}$ can be expressed as $G_{N}=e_{X} * g_{N}$, where the $g_{N}$ is real government expenditures on non-tradables in terms of exportable goods. Based on equation (4.10), the equilibrium price of non-tradables can be expressed as a function of $a, g_{N}, P^{*}{ }_{M}$, and $\pi$ :

$$
P_{N}=v\left(a, g_{N}, \pi, P_{M}^{*}\right), \partial v / \partial a>0, \partial v / \partial g_{N}>0, \partial v / \partial \pi>0, \partial v / \partial P_{M}^{*}>0
$$

After finding the steady-state values of the variables, which ensure the equilibrium on the portfolio market $(a=m+F)$, the financing of the government expenditures fully via taxes, and external sector's equilibrium, equation (4.11) can be used to find the longterm ERER (equation 4.12):

$$
e_{L R}=v\left(m+F, g_{N}, \pi, P_{M}^{*}\right), \partial e_{L R} / \partial a<0, \partial e_{L R} / \partial g_{N}<0, \partial e_{L R} / \partial \pi<0, \partial e_{L R} / \partial P_{M}^{*}<0
$$

Based on equation (4.12), the long-term ERER is seen as a function of the real variables only - so-called 'fundamentals'. "Whenever there are changes in these variables, there will be changes in the equilibrium RER. In the short run, however, changes in monetary variables, such as domestic credit and nominal devaluation, will also affect the RER" (EDWARDS, 1994: 67).

\subsubsection{Determinants of the RER}

The long-term ERER derived from the equation (4.12) can be re-written in the following way:

$$
\ln \left(e_{L R t}\right)=\beta_{0}+\beta_{i} \ln \left(F U N D_{i t}\right)+u_{t}
$$

where $e_{L R t}$ is the ERER and the $F U N D_{i t}$ is the vector of fundamental variables. In the long-run the ERER is determined only by the changes of real fundamentals, while in the short run the RER may deviate from its sustainable level due to temporary fluctuations of real fundamentals as well as monetary and fiscal policies. The short-term path of the RER is defined as follows:

$$
\Delta \ln \left(e_{t}\right)=\Theta\left[\ln \left(e_{L R t}\right)-\ln \left(e_{t-1}\right)\right]-\lambda\left[Z_{t}-Z_{L R t}\right]+\theta\left[\ln \left(E_{t}\right)-\ln \left(E_{t-1}\right)\right]
$$

where $e_{t}$ is the RER, $Z_{t}$ is a vector measuring macropolicies, $Z_{L R t}$ is a vector of policy measures that is consistent with the equilibrium rate, $\lambda$ is the speed of adjustment to the sustainable policy value, $E_{t}$ is the nominal exchange rate, and $\Theta$ is the speed of self-adjustment of the short-term RER to its equilibrium value (the smaller $\Theta$ is, the slower will be speed of the self-adjustment). The meaning of this dynamic equation is relatively straightforward: the RER level adjusts between today and tomorrow in the direction of the equilibrium rate (first term on the right hand side) with some frictions 
represented by the adjustment speed $\Theta$, which can be interpreted as the time needed for relative prices in the economy to adjust. In this process, though, changes in policy variables away from the optimal level (second term) and changes in the nominal exchange rate (third term) may disturb this adjustment in either direction. In essence, this dynamic equation states that the RER has a mean reversion property in the long run, where the mean is the equilibrium rate (MONGARDINI, 1998).

Substituting equations (4.13) in (4.14), it is possible to derive the following reduced form equation for the RER (equation 4.15):

$$
\ln \left(e_{t}\right)=\gamma_{0}+\gamma_{i} \ln \left(F U N D_{i t}\right)+(1-\Theta) \ln \left(e_{t-1}\right)-\lambda\left(Z_{t}-Z_{t}^{*}\right)+\theta N O M D E V_{t}+v_{t}
$$

where the parameters $\gamma_{i}$ are a combination of the respective $\beta_{i}$ and $\theta$, and $N O M D E V_{t}$ is the nominal devaluation. After deriving the elasticities of the equation (4.15) and assuming the long-run elasticities of the nominal depreciation and macropolicy variables are zero, i.e. all policy and nominal factors do not affect the ERER, one can estimate the equilibrium RER.

By using the theoretical framework of the Edwards model and the insights into RER misalignment (see section 2.3.4), the following sections are devoted to econometrically estimate the ERER in Ukraine and to construct RER misalignment index. Then this exchange rate data will be used to estimate the impact of the RER misalignment on agricultural incentives and agricultural growth in Ukraine.

\subsubsection{Determinants of the RER in Ukraine}

In order to proceed with the estimation of equation (4.15), the fundamental variables affecting the ERER need to be identified. According to EDWARDS and SAVASTIANO (1999), most empirical studies of the ERER for emerging economies include the following set of variables or 'fundamentals': terms of trade, output growth (or productivity differentials), the country's openness to international trade, import tariffs, government spending and capital flows. The monetary and fiscal variables, as well as the nominal exchange rates, are usually included to reflect short-term deviations of the RER

The sources of Ukraine's information are the NATIONAL BANK OF UKRAINE (2002b), State StATistics COMMitTEe OF UKRAINe (2001f), and UEPLAC/TACIS (2002). In order to maximally avoid data bias, the quarterly time series start from 1996, after the national currency hryvnia was established and hyperinflation ended. The time series end in 2001Q4. In the study of the RER in Kazakhstan, for example, high inflation period of 1994-1995 was also called as a very unstable for econometric tests (KURALBAEVA et al., 2001). It would be also more suitable to use semi-annual or annual data. But the short history of Ukrainian economy does not allow to proceed in any other way. There are only 24 observations, which for cointegration is an extremely short time series that limits and strongly complicates any econometric efforts. Therefore, below estimations are not completely free of problems. The following variables are used in the estimations: 
1. Real exchange rate (RER): to properly measure the impact of the RER misalignment on relative agricultural prices in Ukraine, the bilateral (UAH/US\$) RER is used instead of the effective RER discussed in section 3.1.3.3. This choice is predetermined by the common measurement of world market prices in $\$$, against which domestic prices are compared. Hence, correction of the price relations by the effective ERER would bias the comparison. The RER in Ukraine is defined as the U.S. wholesales price index multiplied with the nominal exchange rates $(U A H / \$)$ and divided by the consumer price index in Ukraine. An increase (decrease) of the RER means the RER depreciation (appreciation).

2. Technological progress (TECHNO): the theoretical foundation of the impact of technological progress on ERER was proposed by BALASSA (1964). According to BALASSA, productivity should rise faster in the traded compared to the non-traded goods sector. This leads to the increase of the wages in the traded good sector. "The central assumption of the Balassa-Samuelson theory is that wage increases tend to be equalised across sectors" (HALPERN and WYPLOSZ, 2001: 9). Thus, the growth of the wages in the traded good sector spills over to the non-traded good sector. To remain competitive, the non-traded sector should increase prices for its goods.

In addition to the inflation initiated by the non-tradable sector, the raise of wages increases real consumption. "If, as usually considered, demand is biased towards services, the bulk of non-traded goods, the demand side effect reinforces the supply side effect" (HALPERN and WYPLOSZ, 2001: 10). This results in the ERER appreciation, which demonstrates catching-up with the rest of the world rather than RER misalignment.

Technological progress in Ukraine is proxied with the ratio of Ukraine's real industrial output per industrial labour employed. According to the theory, higher productivity growth in the tradable (industrial sector) would induce ERER appreciation. If technological progress expectedly affects RER, then an appreciation of the actual RER is justified and even desirable, because in this case the appreciation means an equilibrium shift of the RER.

3. Openness of economy to international trade (OPEN): import tariffs, export taxes, export subsidies, as well as non-tariff barriers affect the ERER. For example, an introduction or increase of import tariffs will affect relative prices by increasing relative prices of importable goods, reducing import demand and lowering the price of foreign exchange. ${ }^{43}$ This causes prices of tradables in domestic currency to fall in relation to those of non-tradables, implicitly discouraging the production of tradable goods. This initiates switching expenditures from importable to exportable and non-tradable goods with the simultaneous reallocation of the resources to the production of import substitutes and non-tradable goods. Excess demand for non-tradables will be translated into a ERER appreciation to restore internal balance equilibrium. At the same time, an increased absorption of exportables with simultaneous reduction of the imports will lead to the incipient trade deficit. Generally, the greater the elasticity of price level of non-tradable goods with respect to the price of importables, the larger is the RER effect of import restrictions (DEVEREUX and CONNOLLY, 1996).

\footnotetext{
${ }^{43}$ Non-tariff barriers will lead to the similar but more distorted results due to their more unpredictable character.
} 
Various indicators can be used to reflect commercial policy, but the best suited to this study is the rate of openness. An increase of openness induces the ERER depreciation and visa versa. It is defined as ratio of the sum of total exports and imports (or foreign trade turnover) to total GDP (see table 13). According to the definition of openness, both export and import increase (decrease), assuming that nominal GDP remains constant, will cause the ERER to depreciate (appreciate).

4. Government spending (GOV): generally, an increase of government expenditure results in the real appreciation. This works through the increased demand for non-tradables and tradables with expected price increase of the non-tradables. Final effects on the long-term ERER depend on sectoral composition of these changes (MONTIEL, 1999). Therefore, changes in government spending on traded and non-trade goods have different outcomes for the equilibrium path of the RERs (EDWARDS, 1994).

The GOU spends mainly on non-tradable goods. Even the budget expenditures foreseen for the economy (around 15\% of all budget expenditures) can be often considered as the resources directed into non-tradable sectors because they are used to pay labour bills or to encourage current consumption versus investments. Thus, an increase of the government spending in Ukraine would lead to the appreciation of the ERER. The government spending are defined as the budget expenditures divided by total GDP.

5. Capital inflows (CAPFY): the impact of the capital inflows on the ERER depends on the distribution of these inflows between tradable and non-tradable sectors. In general, capital inflows lead to the ERER appreciation as they often inflate prices of nontradables, mainly fixed assets. In most transition economies, capital inflows are endogenous, i.e., demanded domestically or attracted via high domestic interest rates. If they are demanded domestically through high GDP growth, capital inflows are not inflationary, but if they are attracted to finance the budget deficit via high interest rates (and often fixed exchange rate to ensure expected returns in real terms), such inflows lead to the RER appreciation and even its overvaluation. Actually, those capital inflows implicitly proxy the impact of interest rate changes on the RER. Capital inflows in Ukraine are expressed as a ratio of net capital inflows to total GDP.

6. Excessive monetary policy (EXCMON): monetary policy is included into the analysis of the RER to estimate its impact on actual path of the RER in the short run, because in the long run its influence on RER is neutral. Monetary policy is proxied by the growth of domestic credit in excess of growth of lagged real GDP. Excessive monetary expansion unmatched by higher growth in the economy will boost the domestic demand for non-tradables and thus induce an appreciation of the RER. This proxy is not perfect, however, because it assumes a constant velocity of money which is not correct for Ukraine.

7. Fiscal deficit ratio (FISC): the second short-term variable in the model, loose fiscal policy, is proxied by the ratio of fiscal deficit to lagged high powered money (monetary base). Under a flexible exchange rate, an increase in fiscal deficit relative to the lagged monetary base (loose fiscal policy) will increase domestic demand for nontradable goods, and thus lead to an appreciation of the ERER. Under a fixed exchange rate, loose fiscal policy will initially boost domestic demand with the upward pressure on interest rate dampened by capital inflows and no impact on the ERER. In the long run, 
the higher demand for non-tradable goods will put upward pressure on inflation, and thus lead to a ERER appreciation (MONGARDINI, 1998).

8. Nominal devaluation (NOMDEV): the last variable appeared in the right-side of the RER equation is the devaluation of the nominal exchange rate (UAH/\$). It is assumed that the nominal devaluation is a powerful tool to re-establish the equilibrium of the RER, but it affects the RER only in the short run. In the long run, if the sources of original disequilibrium are not eliminated, the RER can start to misalign again (see figure 14 and discussions in section 2.4.2). The annual values of the variables are presented in table 24 .

Table 24: Macroeconomic indicators of Ukraine from RER regression, 1996-2001 (year on average)

\begin{tabular}{lcccccc}
\hline & $\mathbf{1 9 9 6}$ & $\mathbf{1 9 9 7}$ & $\mathbf{1 9 9 8}$ & $\mathbf{1 9 9 9}$ & $\mathbf{2 0 0 0}$ & $\mathbf{2 0 0 1}$ \\
\hline \hline Real exchange rate (RER), 1995Q4 = 100 & 78.9 & 69.0 & 79.1 & 110.8 & 120.8 & 108.9 \\
Technological progress (TECHNO), 1992=100 & 52.6 & 55.6 & 58.0 & 58.6 & 59.5 & 60.8 \\
Openness of economy (OPEN) & 0.9 & 0.8 & 0.9 & 1.0 & 1.2 & 1.1 \\
Government consumption in \% of GDP (GOV) & 43.2 & 49.6 & 41.7 & 38.4 & 39.2 & 37.6 \\
Capital inflows in \% of GDP (CAPFY) & 2.5 & 2.6 & 2.1 & -5.9 & -5.2 & -4.0 \\
$\begin{array}{l}\text { Excess of domestic credit over lagged real GDP } \\
\text { (EXCMON), in \% }\end{array}$ & 10.5 & 4.2 & 14.1 & 5.6 & 6.0 & 1.0 \\
$\begin{array}{l}\text { Ratio of fiscal deficit to lagged monetary base } \\
\text { (FISC) }\end{array}$ & -0.2 & -0.3 & -0.1 & -0.04 & 0.04 & 0.02 \\
$\begin{array}{l}\text { Depreciation of nominal exchange rate } \\
\text { (NOMDEV), in \% }\end{array}$ & 0.9 & 0.6 & 13.2 & 7.7 & 3.3 & -0.7 \\
\hline
\end{tabular}

Source: UEPLAC (2002) and NBU (2002b).

\subsubsection{Econometric estimations of the RER in Ukraine}

\section{Stationarity analysis}

In order to estimate the single-equation (4.15), the two-step error-correction model (ECM) of GRANGER (1986) and ENGEL and GRANGER (1987) is used. According to ENGEL and GRANGER, cointegration implies that an error correction specification is adequate for the underlying data-generating process (and visa versa). As the RER is defined in the way to be influenced by both long-term and short-term variables, the error correction specification allows the latter effects to be captured. In the long run, the RER equation has the following form:

$$
\begin{aligned}
& \ln \left(\text { RER }_{t}\right)=\gamma_{0}+\gamma_{1} \ln \left(\text { TECHNO }_{t}\right)+\gamma_{2} \ln \left(\text { OPEN }_{t}\right)+\gamma_{3} \ln \left(\text { GOV }_{t}\right) \\
& +\gamma_{4} \text { CAPFY }_{t-1}+u_{t}
\end{aligned}
$$

But in the short run, rewriting equation (4.15) in the error-correction model with the variables discussed above gives use the following RER equation (equation 4.17): 


$$
\begin{aligned}
& \Delta \ln \left(\text { RER }_{t}\right)=\gamma_{1} \Delta \ln \left(\text { TECHNO }_{t}\right)+\gamma_{2} \Delta \ln \left(\text { OPEN }_{t}\right)+\gamma_{3} \Delta \ln \left(G O V_{t}\right)+ \\
& +\gamma_{4} \Delta\left(\text { CAPFY }_{t-1}\right)-\lambda_{1} \Delta E X \text { CMON }_{t}-\lambda_{2} \Delta \text { FISC }_{t}+\theta N O M D E V_{t}-(1-\Theta) \ln \left(e_{t-1}\right)+u_{t}
\end{aligned}
$$

The starting point of estimation of equations (4.16) and (4.17) is the stationarity check. Testing the causality between variables implies the specification of dynamic relationships which link them. In order to correctly specify these dynamic relationships, one needs first examine the behaviour of each variable over time to determine whether it is stationary. Failure to do so can lead to a problem of spurious regression, whereby the results suggest that there are statistically significant long-run relationships between the variables in the regression model when in fact all that is being obtained is evidence of contemporaneous correlation rather than meaningful causal relations. If non-stationary variables are found, then one needs to find out whether they are cointegrated in order to infer a causal long-run relationship between non-stationary time series (ZHANG, 1996).

Stationarity can be investigated by means of the "augmented Dickey-Fuller test" (ADF) (DICKEY and FULLER, 1981). If stationarity for a time series is achieved with $d$ times of differences, it is said to be integrated of order $d$ or $\mathrm{I}(d)$. To test whether a time series, $X_{t}$, is nonstationary (or contains a unit root), the following regression model is set:

$$
\Delta X_{t}=\alpha+\beta_{0} X_{t-1}+\sum_{i=1}^{n} \beta_{i} \Delta X_{t-i}+\mu_{t}
$$

where $\mu$ is an error term. The null hypothesis that $X_{t}$ contains a unit root is set at $H_{0}: \beta_{0}=0$, against the alternative $H_{1}: \beta_{0}<0$. The null hypothesis is rejected if $\beta_{0}$ is significantly negative. Even though each individual variable is found to have a unit root, it is still possible to infer a causal long-run relationship between non-stationary variables if they are cointegrated.

Table 25 shows the results of the ADF test. Only TECHNO is stationary in levels, $\mathrm{I}(0)^{44}$, but for all other variables the null of I(1) hypothesis cannot be rejected. The RER is significant at the $10 \%$ of significance, which is very weak indicator of the I(1). The problem is common for all variables - short time series do not allow proper estimation of the stationarity of the data. Assuming that this bias will not negatively impact the final regression results, and taking into account that macroeconomic data series are usually $\mathrm{I}(1)$, the long-term cointegration is further estimated.

\footnotetext{
${ }^{44}$ Testing of another proxy of the technological progress (overall GDP per labour employed) gives similar results. This makes us exclude the variable TECHNO from the cointegration analysis.
} 
Table 25: Augmented Dickey-Fuller test for presence of unit root, 1996Q1-2001Q4

\begin{tabular}{llc}
\hline & Levels & First difference \\
\hline \hline Real exchange rate (RER) & -1.294 & $-2.751(*)$ \\
Technological progress (TECHNO) & $3.047(* *)$ & -0.77 \\
Openness of economy (OPEN) & -0.086 & $-3.045(* *)$ \\
Government consumption in \% of GDP (GOV) & -1.357 & $-4.714(* * *)$ \\
Lagged capital inflows in \% of GDP (CAPFY) & -1.753 & $-3.291(* *)$ \\
Excessive monetary policy (EXCMON) & -1.923 & $-4.083(* * *)$ \\
Ratio of fiscal deficit to lagged high powered money & -1.485 & $-3.887(* * *)$ \\
(FISC) & -1.569 & $-4.283(* * *)$ \\
Depreciation of nominal exchange rate (NOMDEV) &
\end{tabular}

Note: $\quad$ The ADF test is done with a constant term in the fitted regression. Lags are defined by the Akaike information criteria. Asterixs $(*),(* *)$ and $(* * *)$ next to the statistics indicates that the corresponding hypothesis cannot be rejected at the 10,5 and $1 \%$ confidence interval. These and all further estimations are done in GAUSS 4.0 package. Data are seasonally adjusted by using Berliner Method from German Institute for Economic Research (DIW).

Source: Own calculations.

\section{Long-term cointegration}

The long-term cointegration is tested by the DICKEY-FULLER statistics (similarly to analysis made by ELBADAWI, 1994: 104) and results are summarised in table 26. Note that in the long run only real variables matter, thus the proxies of monetary and fiscal policies, as well as nominal devaluation, are not included here (equation 4.16). The test provides strong support for cointegration $(\mathrm{ADF}(0)$ value is statistically significant at $1 \%)$, thus permitting an equilibrium interpretation of the estimate of table 26 , as well as providing a justification for the below error-correction specification.

Table 26: Cointegrating regression, 1996Q1-2001Q4

\begin{tabular}{lrcc}
\hline & Coefficient & T-value & Probability \\
\hline \hline Constant & 6.170 & 9.43 & 0.000 \\
Ln (OPEN) & 1.062 & 6.85 & 0.000 \\
Ln (GOV) & -0.462 & -2.65 & 0.015 \\
CAPFY (-1) & -0.007 & -1.93 & 0.068 \\
\hline $\mathrm{R}^{2}=0.93$ & & &
\end{tabular}

DW statistics $=1.52$

F-test $=89.11$

$\operatorname{ADF}(0)=-4.126(* * *)$

$\mathrm{ADF}$ (critical value at $1 \%$ significance) $=-2.949$

Note: $\quad$ The dependent variable is $\ln (\mathrm{RER})$.

Source: Own calculations.

The estimations strongly corroborate the predictions of the theoretical model: all effects have the expected signs and are statistically significant at conventional levels. The 
openness has a positive effect, indicating that an increase of the openness rate calls for the depreciation of the ERER. The results also indicate that larger capital inflows induce the ERER appreciation. The ratio of the government expenditures to GDP has negative and significant elasticity, implying that largest share of the GOU expenditures is devoted to the non-tradable goods sector. Finally, as the technological change (TECHNO) was excluded from the cointegration regression, its impact on the RER cannot be estimated in our constellation. One could certainly expect the existence of the Balassa-Samuelson effects in Ukraine. If this is the case, its impact could be expected to be around -0.4 (1\% increase of the TECHNO induces $0.4 \%$ of the ERER appreciation), estimated for the sample of the CEE transition economies, including Ukraine, over 1993-1998 (see DE BROECK and SLOK, 2001). At the same time, the Balassa-Samuelson effects could have yet not prevailed in Ukraine during the observed period. This can be explained, for example, by still low utilisation of the production capacities that does not allow an increase of the wages in both tradable and non-tradable sectors, and thus, non-tradable goods inflation to appear (see section 3.1.3.3). Longer and better time series are required to finally clarify this important issue for Ukraine.

In order to better understand the sources of the RER changes, table 27 presents the breakdown in the contribution of the different fundamental variables during 1996-2001.

Table 27: Contribution of economic fundamentals to changes of the RER in Ukraine, 1996Q1-2001Q4

\begin{tabular}{lcc}
\hline & Elasticity & Contribution in \% \\
\hline \hline Rate of openness (OPEN) & 1.06 & 55.8 \\
Government expenditures to GDP (GOV) & -0.46 & 36.3 \\
Lagged capital inflows to GDP (CAPFY) & -0.007 & 7.9 \\
\hline
\end{tabular}

Note: $\quad$ During 1996-2001, ln (RER) increased by roughly 27\%. Calculations in table show the contribution of each real variable to this increase.

Source: Own calculations.

The most important source of changes of the RER over 1996-2001 was the changes in the rate of openness: it accounts for roughly $56 \%$ of the total RER change. At the same time, the immediate role of the capital inflows seems to be relatively small. It could mean that Ukraine had not yet entered the dynamic phase of the development, when the transition from a planned to a market economy is completed to the large extent, and the capital inflows satisfy the demand for capital driven by the internal economic growth. Moreover, the capital inflows were rather the result of large fiscal deficits which 'encouraged' the GOU to increase the interest rate on state securities to such a high level that foreign investors could not resist investing in this market (see section 3.1.2.3). At the same time, the capital inflows certainly have an important effect in the longer term: in our specification the model deals with capital flows, not capital stock. If the capital stock is taken into account, the contribution of the capital to the RER changes will be probably greater. Finally, government expenditures still play very important role in the economic development of Ukraine which means that the role of the state remains significant in determining the economic activities. 


\section{Short-term error correction estimation}

The results of the econometric estimations of the short-term dynamics of the RER are presented in table 28 (estimation of equation 4.17). Despite of the small sample size, the most included variables are significant and explain $70 \%$ of the RER. This indicates that real fundamentals as a group indeed play an important role in determining RER behaviour in Ukraine.

The coefficient of the speed of adjustment of the actual RER to its equilibrium level is quite high and statistically significant $(1-\Theta=0.85)$. It means that $\Theta$ equals 0.15 . From the economic perspective, this small value of $\Theta$ implies that, with other things as given, the actual RER converges very slowly toward its long-run equilibrium level in Ukraine. In one year approximately $48 \%$ of this discrepancy will be corrected. The full adjustment $(99.9 \%)$ takes around 8 years. Such an automatic adjustment in Ukraine is similar to those obtained in EDWARDS (1989) for a group of developing countries (0.19), Mongardini (1998) for Egypt (0.21), and ElBADAWI (1994) results for Chile, Ghana and India (around 0.30).

Table 28: Error correction regression, 1996Q1-2001Q4

\begin{tabular}{lcc}
\hline & Coefficient & T-value \\
\hline \hline Ln (ERER(-1) - RER(-1) & $-0.853(* * *)$ & -3.07 \\
$\Delta$ Ln (OPEN) & $0.834(* * *)$ & 3.86 \\
$\Delta$ Ln (GOV) & $-0.785(* * *)$ & -2.74 \\
$\Delta$ CAPFY $(-1)$ & $-0.007(* * *)$ & -3.05 \\
$\Delta$ EXCMON & 0.148 & 0.859 \\
$\Delta$ FISC & $-0.739(* * *)$ & -2.42 \\
NOMDEV & $0.261(* *)$ & 1.59 \\
\hline $\mathrm{R}^{-2}=0.71$ & & \\
F-test $=5.13$ & & \\
DW $=1.26$ & & \\
\hline
\end{tabular}

Note: $\quad$ The dependent variable is $\Delta$ Ln (RER). $* * *$ means the significance at $1 \%$ level and $* *$ - at $5 \%$ level.

Source: Own calculations.

First proxy of the macroeconomic policy (EXCMON) has unexpected sign, but it is statistically insignificant. There, therefore, no evidence of a relationship between the monetary policy and the RER in Ukraine. The problems can arise from the unperfected approximation of the monetary policy mentioned in section 4.1.1.3. Second proxy of the macroeconomic policy (FISC) is significantly negative. This indicates that, in accordance with the implications obtained from the EDWARDS model, as this policy becomes increasingly expansive, the RER will appreciate. If we start from RER equilibrium and other things remain constant in the short run, this appreciation reflects a mounting disequilibrium. If the budget deficit grew at a rate of $10 \%$, the accumulated annual real appreciation would equal $7.4 \%$. In this sense, the estimates for the macroeconomic 
variable's coefficient strongly support the view that inconsistent policies will result in growing pressure that will generate RER overvaluation (EDWARDS, 1994).

The coefficient of nominal devaluation (NOMDEV) is significantly positive, but the low value of the coefficient indicates that even with all other things given, a nominal devaluation will be converted into a much less than a one-to-one real devaluation in the first year. Although the nominal devaluation can serve as a powerful device to reestablish RER equilibrium, it always has a lasting effect, e.g., it is necessary that sources of the original disequilibrium be eliminated. If this is not the case, soon after the devaluation the RER will again become overvalued (recall section 2.4 .2 and figure 14).

Real variables also influence the RER. The rate of openness and the government spending to GDP are significant and with expected signs. Outward-oriented trade policy incurs the RER depreciation - this is true for increase of both exports and imports. The coefficient of the openness is large $(0.83)$ pointing out the decisive role of the openness rate in determining the RER dynamics in Ukraine. The impact of the government spending is also relatively high (-0.79) proving that an increase of the government expenditures would induce the RER appreciation, confirming the GOU's high propensity of spend to non-tradables. Finally, the increase of the capital inflows induce the RER appreciation, though its impact on the RER (elasticity equals to -0.007) is much weaker in comparison to the impact of the openness of the economy to foreign trade.

\subsubsection{Construction of the RER misalignment indicator}

Construction of the ERER and thus RER misalignment is not straightforward, and it consists of three steps (see EDWARDS and SAVASTANO, 1999). The first step consists of computing 'sustainable' values of the fundamentals. This is typically done by decomposing real fundamentals into 'permanent' and 'transitory' components using various techniques. The second step estimates the long run ERER by using 'permanent' values of real fundamentals and estimated long-term elasticities from table 26. And finally, the RER misalignment is defined as actual RER minus ERER. If the RER misalignment greater (smaller) than 0 , the model would suggest that the currency is undervalued (overvalued).

Let us start with the first step. To decompose the 'permanent' and 'transitory' values of real variables, various techniques can be applied. In the literature a permanent and transitory decomposition is often done by using, for example, the Johansen method (JOHANSEN and JUSELIUS, 1990), the Beveridge and Nilson (1981) technique or trend estimation with Hodrick-Prescott filter. Those techniques are applied for developed, developing and transition economies (EDWARDS and SAVASTANO, 1999; HINKLE and MONTIEL, 1999; CLARK and MACDONALD, 2000; FRAIT and KOMAREK, 2001). Each decomposition technique has its own strong and weak sides, but all of them require relatively long time series. If the time series are short, these econometric techniques are not free of problems. In this is the case, many researchers use so-called 'moving-average' approach (see MONGARDINI, 1998; BAFFES et al., 1999; DOMAC and SHABSIGH, 1999). In this dissertation this 'moving-average' approach is also used. Although the choice of sustainability benchmark becomes arbitrary to a certain extent, this technique is relatively simple and transparent. 
The variables of the interest are openness rate (OPEN), government expenditures (GOV), and capital inflows (CAPFY). The 'permanent' values of the openness rate in Ukraine are distinguished for two periods. For each period, the average actual rates of openness are calculated. During the first period (from 1996 to 1998), the 'sustainable' rate of openness is proxied to 0.95 . The second period begins in 1999Q2 in the aftermath of the financial crisis. The 'sustainable' rate of openness over 1999-2001 is equal to 1.20.

The 'permanent' values of the government expenditures to GDP are also distinguished for two periods - for the years with budget deficit (1996-1999) and with budget surplus (2000-2001). Taking into account the low sustainability of the GOU's borrowing on both domestic and foreign financial markets, and requirements of the Edwards model (state expenditures must be financed only via taxes in the long run), the sustainable values of government expenditures over 1996-1999 are assumed to equal to the government incomes in this period. The average 'permanent' value of GOV during this period, therefore, equals $39.4 \%$. In the years with budget surplus, actual government expenditures are assumed to remain sustainable, being lower than government incomes, allowing the GOU to pay its old debts. During 2000 and 2001, the average value of the 'permanent' GOV was 38.4\%.

Finally, the estimation of the 'permanent' and 'transitory' values of capital inflows to the GDP is conducted by using the approach of COTTANI et al. (1990). Based on this approach, the sustainable value for the net capital inflows are given by

$$
C A P F Y_{t}=\left(g_{t}^{e}-r_{t}^{*}\right) * F_{t}
$$

where $F$ is the desired stock of foreign debt as a percentage of GDP, $g^{e}$ is the expected growth rate in GDP, and $r$ is the world real interest rate. "It is argued that if in a particular year the capital inflow exceeds this sustainable level, the equilibrium RER will appreciate" (DOMAC and SHABSIGH, 1999: 17). To detect the years in which Ukraine may have over-borrowed, the following procedure is utilised. The expected growth of the GDP $\left(g^{e}\right)$ is proxied by lagged GDP growth in Ukraine. The world interest rate $\left(r^{*}\right)$ is calculated by subtracting expected foreign inflation (lagged U.S. inflation) from the nominal interest rate of Ukrainian commercial banks. Accordingly, if $g_{t}^{e}>r_{t}{ }_{t}$ then both positive and negative values for $C A P F Y_{t}$ are considered sustainable. However, if $g_{t}^{e}<r_{t}{ }_{t}$, then positive values of $C A P F Y_{t}$ are considered unsustainable.

Since the foreign direct investments are usually considered to be more sustainable and less sensible to interest rate changes than short-term and portfolio inflows, their values are assumed to be permanent. Permanency of other capital flows are judged by above explained procedure. Since 1999Q2, the capital flow out from the country. To smooth this data, the average rate of net capital inflow for 1999Q2-2001Q4 is assumed to equal the permanent value of net capital inflows in that period.

Figure 34 depicts the actual and equilibrium RERs in Ukraine and figure 35 shows the rates of the RER misalignment during the observed period. It is worth stressing again that the constructed RER misalignment index should be treated with caution. Quarterly data biases the results to a certain extent and during some periods the RER misalignments are probably not so large as depicted in figure 35. However, the RER misalignments during 1996-1998 and 1999-2000 are obvious. 
Figure 34: Actual and equilibrium real exchange rates in Ukraine, 1996-2001

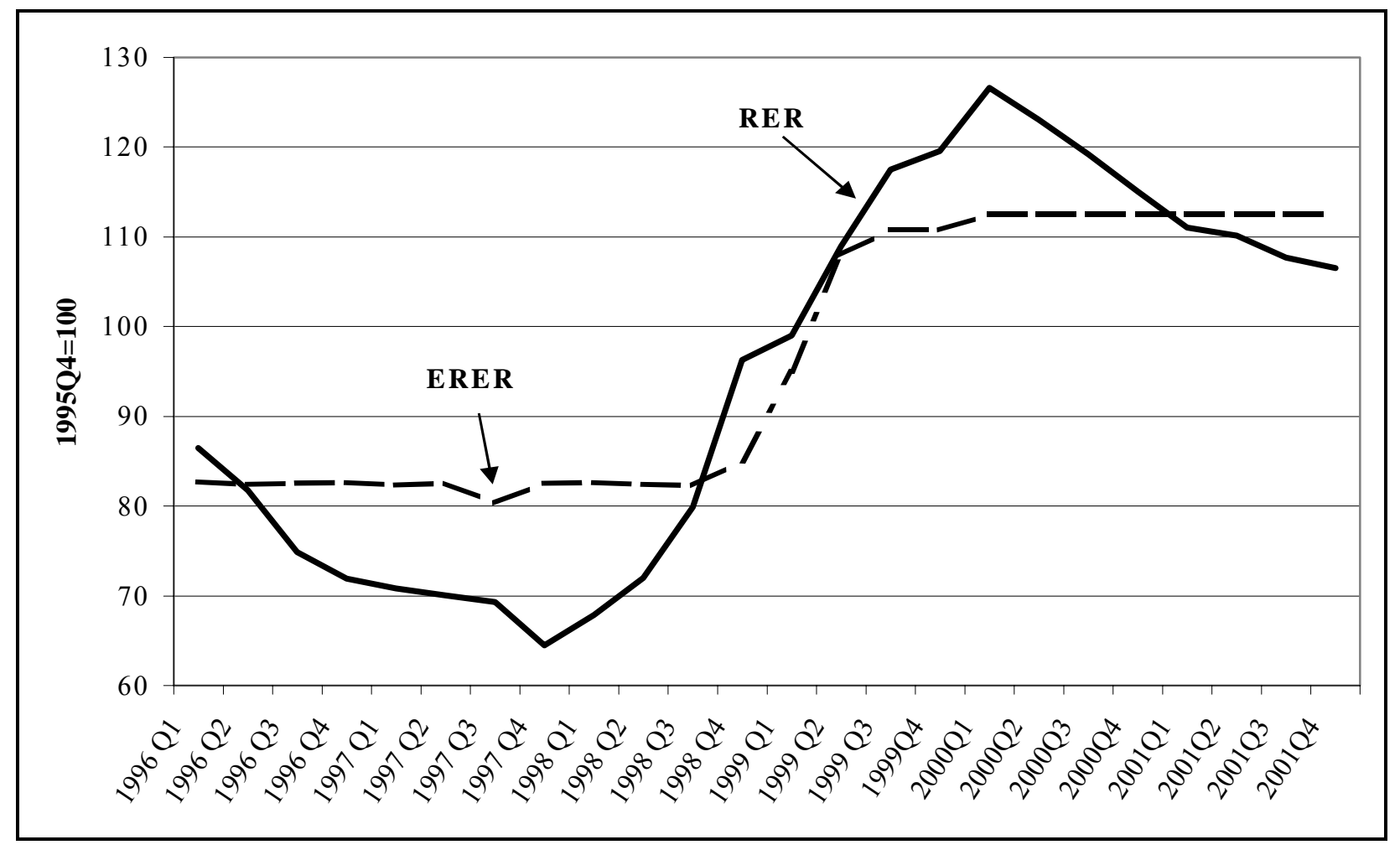

Source: Own calculations.

Figure 35: Misalignment of the RER in Ukraine, 1996-2001, in \% to ERER

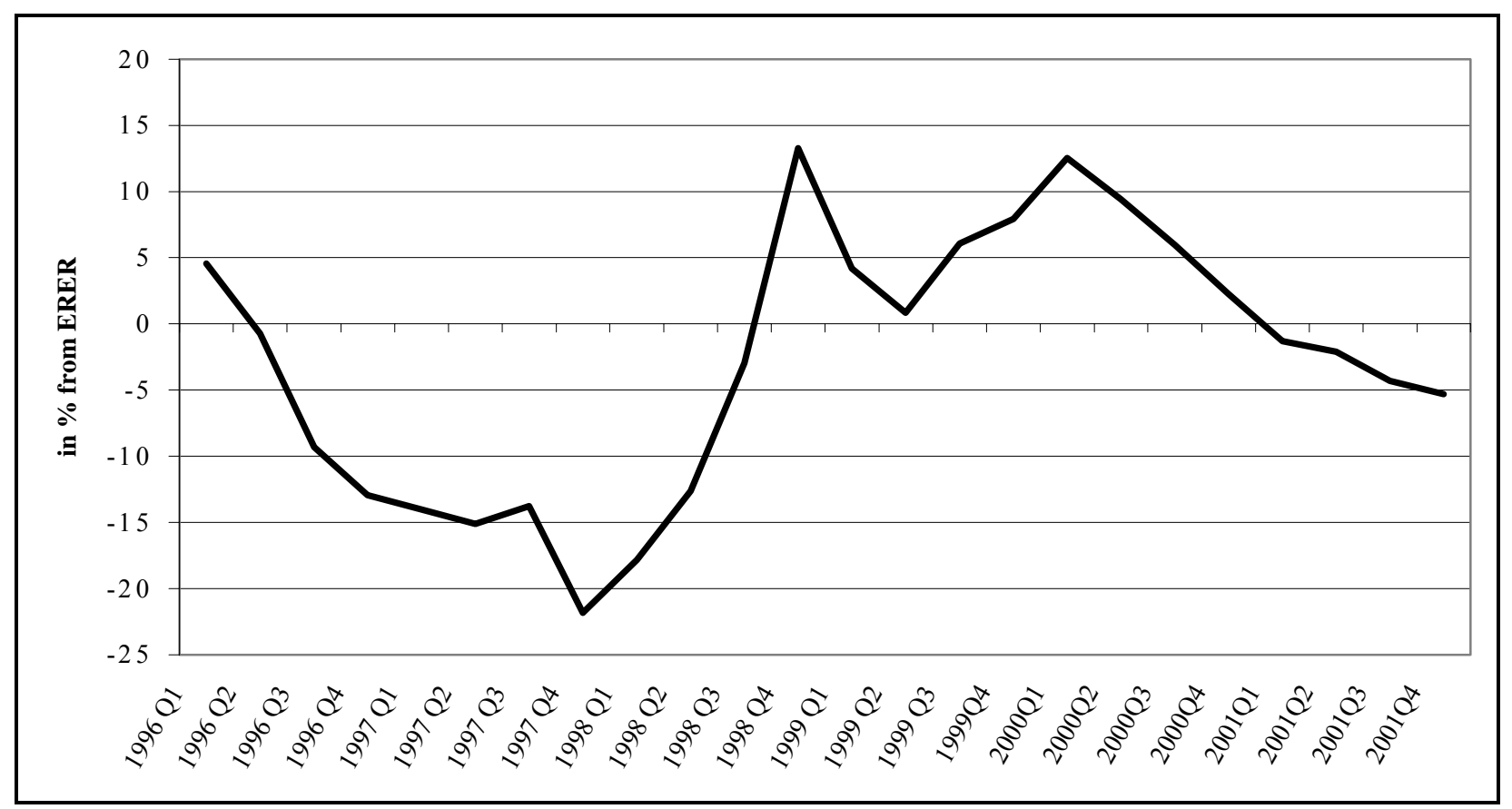

Source: Own calculations.

Developments of the actual and equilibrium RERs in Ukraine during 1996-2001 fit the explanations given in section 3.1.3.3. In 1996Q1, the RER was still slightly undervalued, but it continuously appreciated. This appreciation accelerated in 1997 and over 1996Q2-1998Q4, the RER became overvalued. The peak of the overvaluation was reached in 1997Q4 (21.9\%). In general, the RER in Ukraine was overvalued by $4.6 \%$ in 
1996, $16.2 \%$ in 1997 and 5\% in 1998. In this period Ukrainian economy experienced high government expenditures, unsustainable capital inflows, slow structural changes, and inward-oriented trade policy. Financial crisis in 1998Q4 clearly demonstrated how the macroeconomic mismanagement in an open economy can be punished. Based on the theoretical foundations of section 2.4.2 and figure 14, the only policy choice for the GOU was to devalue.

The devaluation started in 1999, but the GOU tried to avoid a sharp devaluation. In 1999 , the RER was undervalued by roughly $4.8 \%$. In 2000 , the NER started to float, and the actual RER overshoot its equilibrium by $12.5 \%$ in $2000 \mathrm{Q} 2$. In this period, the rate of openness reached its peak, state finances were balanced, and foreign capital flowed out from the country. In 2001, the actual RER returned to its appreciation path, slightly misaligned within a year by $3 \%$. In that year the rate of the openness slightly decreased, decreasing the actual RER. In 2001 Ukraine also experienced a strong GDP growth at $9 \%$, i.e. the Ballasa-Samuelson effect could really took place, and that could not be revealed by the econometric calculations. If the elasticity from the above-mentioned study of DE BROECK and SLOK (2001) is true for Ukraine (-0.4), the expected appreciation in 3.6\% equals our RER misalignment. Therefore, in 2001 the actual RER probably just returned to its equilibrium level. In the following sections the impact of the RER misalignment on relative agricultural prices and economic growth in Ukraine will be estimated.

\subsubsection{Impact of macroeconomic policy on agricultural incentives}

The impact of the RER misalignment and the industrial protection on agricultural incentives in Ukraine is studied by using the KRUEGER-SCHIFF-VALDES methodology described in the theoretical part of this dissertation (see section 2.3.3). Data for the analysis is derived from the above sections: agricultural prices and value-added are taken from section 3.2.6.4; the index of the RER misalignment - from section 4.1.1.5; and the rate of industrial import protection - from table 14. The rate of industrial import protection is additionally increased by $20 \%$ in all years to account for various non-tariff barriers, which are significant in Ukraine indeed (see sections 3.1.4 and 3.2.6). The share of non-agricultural tradable goods in total non-agriculture is assumed to equal $40 \%$, while the share of non-tradable goods (construction, transportation, communication and other services) is correspondingly proxied to $60 \%$ in all the years (calculations based on IMF, 2001). It is also assumed that all agricultural products are tradable: this assumption is very close to the reality for crop commodities in Ukraine, while this is not always true for livestock products originated from small households. High 'transaction costs' do not allow these potentially tradable commodities to be sold to the traders for further reselling on the international markets. The results of the estimation of the nominal and effective direct and indirect protection rates are summarised in table 29 .

Results of table 29 show that the estimations of the nominal and effective rates of protection presented in tables 21 and 22 without taking into account the ERER and industrial protection are biased, and that macroeconomic policy and non-agricultural prices are very important for agriculture. In all years, the impact of indirect sources on both NPR and EPR was significant indeed. 
Table 29: Nominal and effective rates of protection of several crop products in Ukraine, in \%, 1996-2001

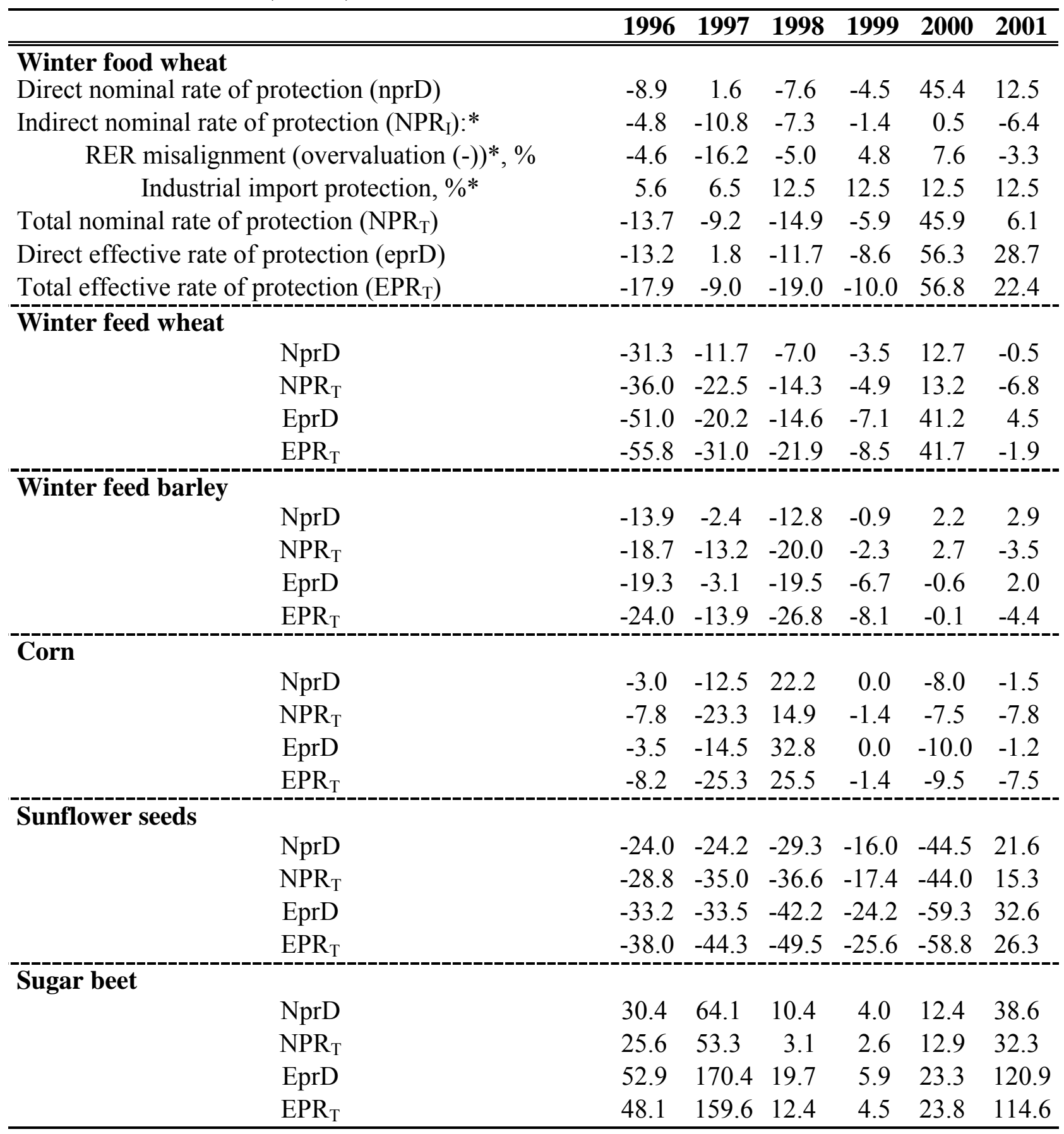

Note: $\quad *$ These indicators are the same for all products, therefore they are shown only once.

Source: Own estimations.

Figure 30 allows making a better look on this issue. This figure presents the average NPRs for five exportable products: milling and feed wheat, corn, barley, and sunflower seeds. Until 2000, these products were directly taxed and rather significantly. But the 'true' level of taxation was even higher when the effects of macroeconomic policy (RER misalignment and industrial protection policies) were accounted for. During 19971999, an impact of indirect policies on agricultural prices was even larger than an impact of the agricultural policy itself. In 2000, the agriculture was directly supported, but the 
'true' level of support was in reality higher due to the RER undervaluation. In 2001, although the agricultural prices were directly supported, indirect taxation greatly neutralised this support. In general, during 1996-2001 the average total NPR (EPR) in Ukraine equalled $\mathbf{- 9 . 9 \%}(-11.3 \%)$, including direct NPR (EPR) in Ukraine $\mathbf{- 4 . 9 \%}$ (6.2\%) and indirect support $\mathbf{- 5 . 0 \%}$. The results obtained suggest that during the observed period the macroeconomic policy was at least seemingly important for agricultural incentives in Ukraine as the agricultural policy itself. In several years, it affected the agricultural relative prices even more than sector-specific policies.

Figure 36: Aggregated direct and indirect NPR on average for wheat, barley, corn, and sunflower seeds in Ukraine, 1996-2001

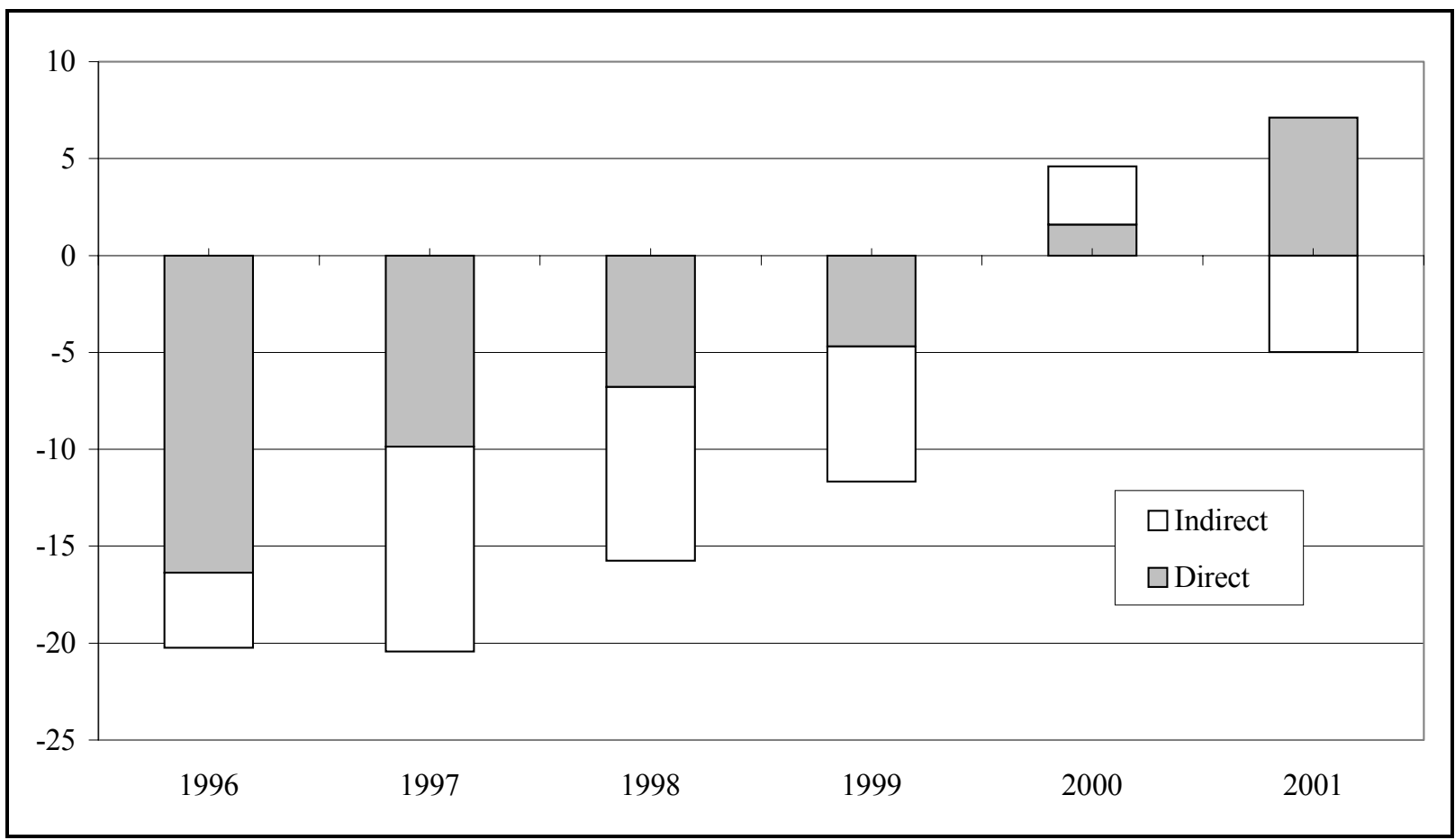

Note: Data for sugar beet is not accounted as it is the importable product, and the total average results with an inclusion of the sugar beet will be, therefore, biased.

Source: Own presentation.

\subsubsection{RER misalignment and agricultural growth in Ukraine}

This section explores the link between RER misalignment and agricultural growth in Ukraine. "Many previous growth studies included the RER indicators as explanatory variables, typically finding the RER instability to be associated with the significantly lower growth" (RAZIN and COLLINS, 1997: 14). In our case the constructed RER misalignment indicator will be used to estimate the impact of the RER misalignment on GAO growth. Arguably, the misalignment of the RER, not the level of the RER or its variability, should be associated with lower growth.

The long-term relationship between the agricultural output and the RER misalignment can be expressed in a very simplified way:

$$
\ln (G A O)=\kappa_{0}+\kappa_{1} R E R M I S+\varepsilon
$$


where $G A O$ is the real agricultural output expressed in the \$ (UEPLAC, 2002), ${ }^{45}$ RERMIS is the RER misalignment and $\varepsilon$ is the error term. This is clear that the GAO was determined not only the RER misalignment. The determinants such as agricultural terms of trade, farm investments, farm structure, human capital or weather probably played much more important role than the RER misalignment. But an absence of quarterly data does not allow including these variables into the above equation, therefore we will look at the impact of only one variable on agricultural output.

Similarly to the above RER econometric analysis, the stationarity check of the data is a starting point of testing cointegration. According to the procedure explained in section 4.1.1.4 the variables of interest are tested by the ADF test. The results of this test are reported in table 30 . The null hypothesis of I(1) cannot be rejected. These results allow estimating the cointegration relationship.

Table 30: Augmented Dickey-Fuller test for presence of unit root, 1996Q1-2001Q4

\begin{tabular}{llcc}
\hline & & Levels & First difference \\
\hline \hline & Real GAO & -1.251 & $-3.507(* *)$ \\
& RERMIS & -1.780 & $-3.191(* *)$ \\
\hline Note: & The ADF test is done with a constant term in the fitted regression. Asterix $(* *)$ next \\
& to statistics indicate that the corresponding hypothesis cannot be rejected at $5 \%$ \\
& confidence interval. &
\end{tabular}

Source: Own calculations.

Again, similarly to the econometric procedure presented above, Granger two-step approach is used here to look at the relationship between the variables in question. The error-correction model is specified in the following way:

$$
\Delta \operatorname{Ln}(G A O)_{t}=\chi_{0}+\chi_{1} \Delta R E R M I S_{t}+\chi_{n} \Delta \text { RERMIS }_{t-n}+\Omega_{e c t} t_{t-1}+u_{t}
$$

where $n$ is a number of lags, ect is the error-correction term and $\Omega$ is a speed of adjustment of the real GAO to its long-term value.

The results of the error-correction model are presented in table 31 . The leg length was chosen using the Akaike information criteria. The results show that $1 \%$ of contemporary increase of the RERMIS causes $0.02 \%$ decrease of the real GAO, while the lagged RERMIS (3 quarters) additionally decrease the real GAO by $0.01 \%$. Although the RER misalignment has an expected sign, its influence on agricultural output growth seems to be small. It can be partially explained by an exclusion of other important variables from the agricultural growth equation. In the combination with those variables (see above), the RER misalignment could affect the agricultural growth greater.

\footnotetext{
${ }^{45}$ Other alternative proxy of the real GAO can be the GAO value in constant 1996 prices, but quarterly time series of this indicator are available only since 1997. Moreover, data for several quarters in 2000 is absent.
} 
Table 31: Error-correction regression of agricultural growth in Ukraine

\begin{tabular}{lcc}
\hline & Coefficient & T-statistics \\
\hline \hline Error-correction term & -0.872 & -3.901 \\
$\Delta$ RERMIS $_{\mathrm{t}}$ & -0.02 & -4.319 \\
\hdashline$\Delta \mathrm{RERMIS}$ & -0.006 & -2.239 \\
\hdashline $\mathrm{R}^{2}=0.607$ & & \\
$\mathrm{DW}=1.570$ & & \\
\hline
\end{tabular}

Note: $\quad$ The dependent variable is $\Delta \operatorname{Ln}(\mathrm{GAO})$.

Source: Own calculations.

In spite of the fact that it is still impossible to distinguish an importance of the macroeconomic policies for the agricultural growth in Ukraine compared with the agriculture-specific issues, after numerous agriculture-specific problems are resolved and agricultural institutions are set, the macroeconomic policy will play much more pronounced role for the agricultural development than it plays now. 


\subsection{Interest rates and agriculture in Ukraine}

After the impact of the RER on agriculture is studied, the next step is to look at the effects of interest rates on Ukrainian agriculture. The empirical analysis uses theoretical foundations presented in section 2.4, and the section begins with the analysis of linkages between the RER and the real interest rate. Then the importance of the interest rate for farm production costs, farm debts and long-term investments is shown in different examples. Finally, the effects of the interest rate on commodity storage are analysed. Although the theoretical part also includes the section about the relationships between the interest rate and land prices, this issue is still hypothetical in Ukraine and thus excluded from the analysis: agricultural land is not yet a subject to purchase and sale.

\subsubsection{Real exchange and interest rates in Ukraine}

Before looking at agriculture-specific issues, let us consider the interdependencies between RER and real interest rate. This analysis foresees to demonstrate how a sound macroeconomic policy is important not only to keep the RER close to its sustainable level, but also to keep the real interest rate low. The theoretical foundations of this analysis are proposed in section 2.4.2.

First, the real interest rate in Ukraine should be properly defined. There are many concepts and measurements of the real interest rate. "It can be defined as the actual riskfree rate of interest discounted by the expected rate of inflation. There are of course no risk-free rates of interest to observe, nor can one directly observe expected inflation. Thus it is common for ex ante real interest rates to be identified with nominal rates of interest on commercial bank loans, deflated by the current rate of inflation. This is a rough and ready proxy" (SNAPE, 1989: 524). Thus, the real interest rate is usually calculated by using so-called FISCHER equation, i.e. the nominal interest rate minus inflation rate:

$$
i_{r}=i_{n}-C P I
$$

where the $i_{r}$ is the real interest rate, $i_{n}$ is the nominal interest rate, and the CPI is the rate of inflation. For example, if the nominal interest rate equals to $10 \%$ per year and the rate of inflation equals to $4 \%$, then the real interest rate will be $6 \%$. However, in the inflationary environment, this type of calculation leads to an overestimation of the real interest rate. To be correct in the years of high inflation it is better to use indices, not percentage changes. The equation (4.22) shows this approach (see in BRANDES and ODENING, 1992: 131):

$$
i_{r}=\frac{\left[1+i_{n}\right]}{[1+C P I]}-1
$$

The real interest rates in Ukraine estimated by both methods are presented in table 32. Especially in the years of high inflation, results greatly differ. In 1994, when the inflation rate reached $400 \%$, the deviation between two real interest rates equalled to $120 \%$ points. Even during lower inflation years, the deviations were substantial - for example, in 1999 the 'true' real interest rate (equation 4.23) was 5.8\% points lower than those calculated by the simplified approach. In 2001, when the inflation rate was moderate for Ukrainian standards, the deviation between two real interest rates was very 
small (1.5\% points). Hence, the real interest rates estimated by equation (4.23) are used for further empirical analysis.

Table 32: Calculation of the real interest rates in Ukraine, (in \%, end of year), 1994-2001

\begin{tabular}{lcccccccc}
\hline & $\mathbf{1 9 9 4}$ & $\mathbf{1 9 9 5}$ & $\mathbf{1 9 9 6}$ & $\mathbf{1 9 9 7}$ & $\mathbf{1 9 9 8}$ & $\mathbf{1 9 9 9}$ & $\mathbf{2 0 0 0}$ & $\mathbf{2 0 0 1}$ \\
\hline \hline $\begin{array}{l}\text { Commercial bank nominal } \\
\text { lending interest rate }\end{array}$ & 249.6 & 126 & 80.4 & 49.2 & 54.0 & 55.2 & 42.0 & 32.4 \\
$\begin{array}{l}\text { Consumer Price Index in Ukraine } \\
\text { (1) Real interest rate }\end{array}$ & 400.0 & 181.7 & 39.7 & 10.1 & 20.2 & 19.2 & 25.8 & 6.1 \\
$\begin{array}{l}\text { (equation 4.22) } \\
\begin{array}{l}\text { (2) Real interest rate } \\
\text { (equation 4.23) }\end{array}\end{array}$ & -150.4 & -55.7 & 40.7 & 39.1 & 33.8 & 36.0 & 16.2 & 26.3 \\
\begin{tabular}{l} 
Deviation between (1) and (2) \\
\hline
\end{tabular} & -30.1 & -19.8 & 29.1 & 35.5 & 28.1 & 30.2 & 12.9 & 24.8 \\
\hline
\end{tabular}

Source: $\quad$ Own calculations based on UEPLAC (2002).

Figure 37 demonstrates the development of both real interest and exchange rates in Ukraine and distinguishes four distinct periods. In the period 1 (1996Q1-1998Q3), the real interest rate in Ukraine was kept high to attract the foreign capital to finance the budget deficit and the deficit of the current account (see section 3.1.3.3). Exactly what Mundell-Fleming model says, the monetary policy was ineffective to stimulate economic growth as the GOU had committed to maintain the NER at the predetermined level. As a result, the RER appreciated to the overvalued level (see section 4.1.1). This period can be considered as the period of double-taxation of Ukrainian farmers (and the economy as a whole), since the RER overvaluation was accompanied by high interest rates.

In the period 2 (1998Q3-1999Q4) Ukraine experienced financial crisis and strong state intervention into the exchange market. Dramatic banking crisis strengthened this disorder. During this period the GOU tried to maintain a 'slowly dying' fixed exchange rate and to limit sharp capital outflows. Due to the high inflation shock in 1998Q4, the real interest rate first decreased, but then increased to the high pre-crisis level. Again, Ukrainian farmers were negatively affected by both variables and overall macroeconomic disorder. 
Figure 37: Development of the effective RER and real interest rates in Ukraine, 1996-2001

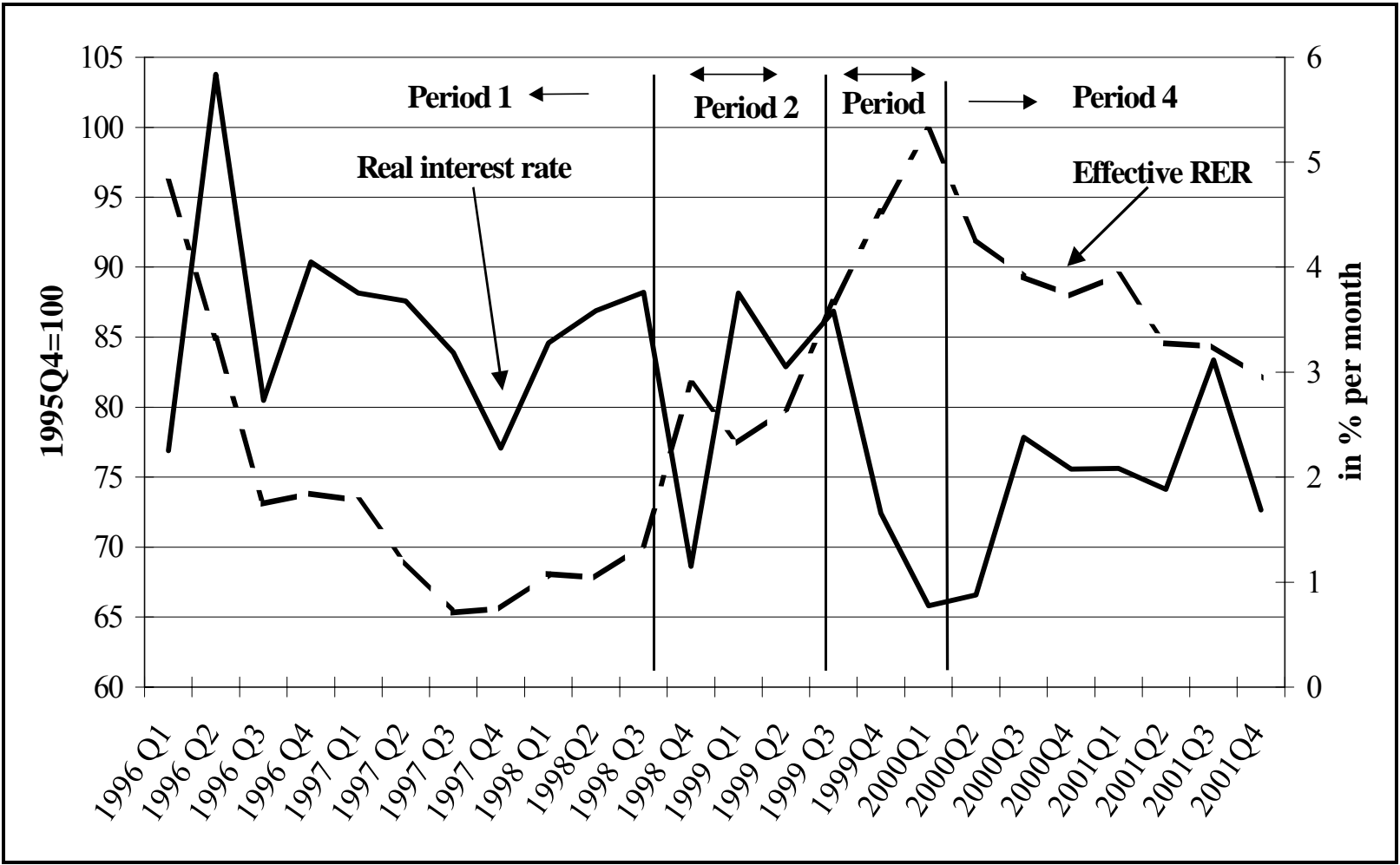

Source: Own presentation based on UEPLAC (2002).

In the third period (1999Q4-2000Q2), positive macroeconomic developments triggered a gradual interest rate decrease. Foreign capital continued to flow out of the country and that encouraged the RER depreciation. At the end of this period, real interest rate reached its lowest level since 1996. In such a situation, Ukrainian farmers enjoyed a good basis for competitiveness: low interest rates and favourable exchange rate level. Moreover, commercial banks started to pay more attention to the real economy since previously attractive market of state securities had collapsed.

Finally, period 4 (2000Q2-2001Q3) is characterised by macroeconomic stabilisation, and consequent economic growth. The RER gradually appreciated, though the GOU did not allow the RER to significantly overvalue again. The real interest rate stabilised at roughly $2 \%$ per month with temporary fluctuations due to seasonal inflation factors. During this period, farmers were granted relatively low interest rates and a soundly managed exchange rate. The positive effects of such a macroeconomic policy translated into strong agricultural growth. In 2001, the real GAO increased by $10.2 \%$ (SSCU, 2002).

\subsubsection{Interest rates and farm production costs in Ukraine}

Similarly to the structure of previous section, the definition of the real interest rate with respect to agriculture is considered firstly. The issue of concern is the use of 'average' interest rate in designing agricultural policy in Ukraine. According to AGRIUKRAINE (2002), in the spring of 2002 the commercial banks lent credits to the farms in Ukraine at $24-35 \%$ per year (in the nominal terms). The difference between 
minimum (24\%) and maximum (35\%) lending rate is $9 \%$ points. Why does the lending rate for Ukrainian farms vary so large?

Because the interest rate for each farm can be called as 'unique' or 'effective'. The 'unique' rate of interest is ensured through the differences in the risk premium for each credit contract and in inflation rates for the farms in question. The most important factors of the level of the lending interest rate are graphically presented in figure 38 .

\section{Figure 38: Important factors of determining credit interest rates}

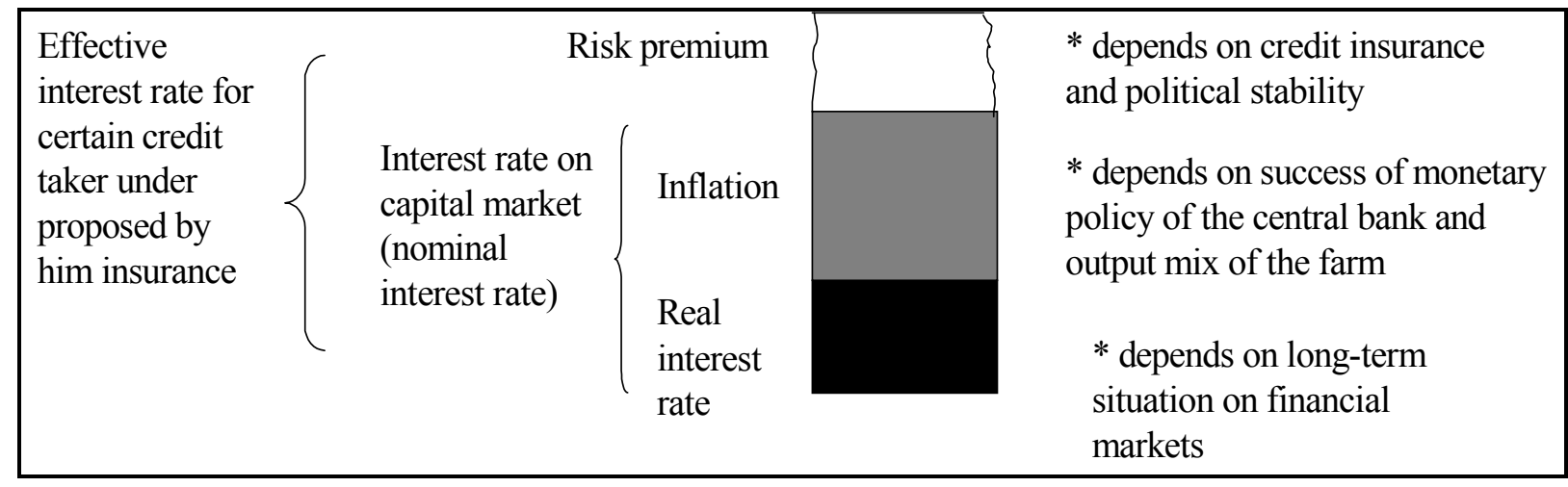

Source: Own presentation based on SCHEUERLEIN (1997: 101)

The issue of the risk premium is well-known and is often mentioned in policy discussions in Ukraine. The availability of secured collateral greatly reduces the 'costs' of the credits. Moreover, political stability and predictability are similarly important determinants of the effective interest rate for the farms as the collateral issues (see STRIEWE et al., 2001a; STRIEWE et al., 2001c with detailed analysis of the supply and demand side of the credits in Ukrainian agriculture).

The uniqueness of the interest rates for the farm in question is also ensured by the 'unique' rate of inflation for that farm. Assuming that agricultural input prices are similar for all farms (farmers are usually price-takers), the real interest rate for 'grain farmer' in 2000 , for example, was much lower than for the 'sunflower seeds farmer' - the prices for sunflower seeds in 2000 increased by only 10\% (compared with 1999), while wheat prices increased twofold. In 2001, the situation diametrically changed - the oil seed producers enjoyed a sharp increase of the prices (almost 120\%), while the prices for wheat decreased from UAH 900 to UAH 500 per ton (SSCU, 2001d), i.e. the seed farmers had to pay lower real interest rates than their grain 'colleagues'.

Usually, the Consumer Price Index is used to calculate the real interest rate - this index presents the growth of the consumption prices for certain basket of foodstuffs, nonfood goods, and services of the 'average' Ukrainian. Is this comparable with the inflation rates of the agricultural producers discussed above? Certainly no, although it remains a good and simply proxy in general.

For the purpose of policy analysis, therefore, consideration of 'average' interest rates should be done with caution. This is especially important for Ukraine, where the farms perform very heterogeneously and where the state interventions on the local level are sometimes pervasive (ZORYA and VON CRAMON-TAUBADEL, 2002). In such an environment, the use of 'average interest rate' for farm subsidisation is similarly questionable as the use of 'average' rate of profitability and 'average' production costs to 
maintain certain 'minimum profits' for farms. At the same time, the calculations with average figures help to estimate the magnitude of certain effects and the trends of general development. Hence, the following estimations of the impact of 'average' real interest rates on 'typical' costs of the farm production in Ukraine have to be interpreted with caution, when farm support objective is, for example, considered.

In section 2.4.3 it was said that any production technology consists of variable and fixed costs. Farmers often purchase intermediate inputs (seeds, fertilisers, fuel or chemicals) by using short-term credits in the terms of roughly half a year. The investments into agricultural machinery and equipment (or livestock buildings) require long-term financing which can be covered either by commercial banks, leasing companies or state agents. Farmers pay interest for use of these long-term financial resources. The interest paid can greatly affect production costs and the magnitude depends on the share of capital in total production costs. In the following, 'typical' costs of producing several major crops in 2001 are calculated (see scheme in table 4). At the outset, it has to be stressed that these calculations are certainly not beyond criticism. Natural conditions vary considerably within Ukraine, so the assumptions on costs will never fit perfectly. However, they can serve as a good 'proxy' of reality, anywhere.

Five crop products are considered here: winter wheat, winter feed barley, corn, sunflower seeds, and sugar beet. To gather data at the farm level, field work was conducted in Lviv, Ternopil, Zhytomyr, Vinnitsa and Cherkassy oblasts. ${ }^{46}$ These oblasts represent almost all agro-climatic zones in Ukraine (Lviv and Ternopil - west, Zhytomyr - middle-north, Cherkassy and Vinnitsa - middle-east). The input-output matrix was built based on collected farm data, data from inputs suppliers, and suggested production technologies from Ukrainian agricultural institutions (PANKIV et al., 2000; SPYCHAK, 2000; KSTUA, 2001). While technical coefficients change over time, the coefficients used here are up-to-date.

Variable inputs include fertilisers, chemicals, seeds and fuel. Input prices are those from section 3.2.6.4 needed to calculate the effective rates of protection. All inputs are assumed to be purchased by farms by using short-term credits with half a year maturity.

Estimation of the value of domestic resources (land, labour and capital) is not straightforward. The following technique was used. For land the opportunity costs are assumed to equal its average rental value. Land lease in Ukraine was legalised only in $1998 .^{47}$ Prior to this time, agricultural land belonged to the members of the collective farms and leasing was not permitted. According to the official statistics, leasing payments in 2001 equalled to UAH 120 per ha.

The opportunity cost of labour is equal to its marginal product in the next best alternative. Labour in the rural areas of Ukraine usually has very few alternatives. Due to high unemployment in urban areas and low capacity utilisation by industrial enterprises,

\footnotetext{
${ }^{46}$ Farm data for Lviv and Ternopil oblasts were collected in October 2001. Data on Zhytomyr oblast was taken from NEDOBOROVSKYY (2001). Data on Vinnitsa and Cherkassy oblasts are based on the meetings with DUAP staff and BENECKE (2000).

${ }^{47}$ Law of Ukraine "On land Leasing" dated October 6, 1998 allowed the leasing of the agricultural land.
} 
household production remains the best job alternative for most rural workers. If the labour market functions properly, farm members will equalise the return from the last hour spent on the farm and on their household plots, respectively. However these returns are difficult to quantify. For example, farm members receive not only wages from their farms, but also different social payments and other incentives. The opportunity cost of labour is assumed to be equal to the wages in crop production of the large farms.

As the information on marginal productivity of capital in its next best alternative use is not available in Ukraine, costs of capital are proxied to the sum of accrued depreciation and real interest rate (see, for instance, BANSE et al., 1998). The real interest rate is fixed at $24.8 \%$ (see table 32 ). Depreciation rates of agricultural machinery and equipment in Ukraine are reported in KSTUA (2001). ${ }^{48}$ All machines and equipment underlying the calculations are produced in Ukraine with the exception of harvesters (data on used Class grain harvesters and Holmers sugar beet harvesters were used), which were not produced in Ukraine until recently. Results of the calculation are presented in tables 33 and 34 .

Table 33: 'Typical' production technologies and costs of major crops in Ukraine in 2001

\begin{tabular}{l|l|ccccc}
\hline Item & \multicolumn{1}{|c|}{ Units } & $\begin{array}{c}\text { Winter } \\
\text { wheat }\end{array}$ & $\begin{array}{c}\text { Winter feed } \\
\text { barley }\end{array}$ & $\begin{array}{c}\text { Corn } \\
\begin{array}{c}\text { Sunflower } \\
\text { seeds }\end{array}\end{array}$ & $\begin{array}{c}\text { Sugar } \\
\text { beet }\end{array}$ \\
\hline \hline Seeds & $\mathrm{kg} / \mathrm{ha}$ or units & 200 & 200 & 60 & 6 & 2 \\
& $\mathrm{UAH} / \mathrm{ha}$ & 107 & 57 & 53 & 112 & 107 \\
Fertiliser & $\mathrm{kg} / \mathrm{ha}$ & 50 & 20 & 20 & 20 & 160 \\
& $\mathrm{UAH} / \mathrm{ha}$ & 25 & 16 & 18 & 10 & 127 \\
Crop Protection & $\mathrm{kg} / \mathrm{ha}$ & 1.4 & 1.2 & 1.2 & 1.2 & 3 \\
& $\mathrm{UAH} / \mathrm{ha}$ & 166 & 53 & 53 & 80 & 435 \\
Fuel & $\mathrm{kg} / \mathrm{ha}$ & 65 & 60 & 65 & 40 & 200 \\
& $\mathrm{UAH} / \mathrm{ha}$ & 89 & 83 & 89 & 55 & 276 \\
Short-term interest rates & $\mathrm{UAH} / \mathrm{ha}$ & 54 & 29 & 30 & 36 & 126 \\
\hline Sum of variable costs & $\mathrm{UAH} / \mathrm{ha}$ & $\mathbf{4 4 0}$ & $\mathbf{2 3 7}$ & $\mathbf{2 4 2}$ & $\mathbf{2 9 3}$ & $\mathbf{1 0 7 0}$ \\
\hline \hline Labour & $\mathrm{Hour} / \mathrm{ha}$ & 45 & 40 & 100 & 44 & 200 \\
& $\mathrm{UAH} / \mathrm{ha}$ & 81 & 72 & 180 & 72 & 540 \\
Land & $\mathrm{UAH} / \mathrm{ha}$ & 120 & 120 & 120 & 120 & 120 \\
Fixed capital costs, incl. & & & & & & \\
Depreciation & $\mathrm{UAH} / \mathrm{ha}$ & 729 & 710 & 865 & 757 & 1516 \\
Long-term interest rates & $\mathrm{UAH} / \mathrm{ha}$ & 241 & 234 & 285 & 250 & 474 \\
\hline Sum of fixed costs & $\mathrm{UAH} / \mathrm{ha}$ & $\mathbf{1 1 7 1}$ & $\mathbf{1 1 3 6}$ & $\mathbf{4 5 0}$ & $\mathbf{1 1 9 9}$ & $\mathbf{2 6 5 0}$ \\
\hline \hline Total production costs & $\mathrm{UAH} / \mathrm{ha}$ & $\mathbf{1 6 1 1}$ & $\mathbf{1 3 7 3}$ & $\mathbf{1 6 9 2}$ & $\mathbf{1 4 9 2}$ & $\mathbf{3 7 2 0}$ \\
\hline Source: & & & & &
\end{tabular}

Source: Own calculations.

\footnotetext{
${ }^{48}$ Only agricultural machinery and equipment is used to calculate capital costs. Ukrainian farms posses fixed assets as well, but the data on these assets are not available or highly unreliable (the value of these assets is often overestimated in farm balance sheets).
} 
Table 34: Structure of production costs of selected agricultural products in Ukraine in 2001 (in \% to total costs)

\begin{tabular}{|c|c|c|c|c|c|}
\hline Costs & $\begin{array}{l}\text { Winter } \\
\text { wheat }\end{array}$ & $\begin{array}{l}\text { Winter } \\
\text { barley }\end{array}$ & Corn & Sunseeds & Sugar beet \\
\hline \multicolumn{6}{|l|}{ Variable costs } \\
\hline Seeds & 6.6 & 4.2 & 3.2 & 7.5 & 2.9 \\
\hline Fertilisers & 1.6 & 1.2 & 1.1 & 0.7 & 3.4 \\
\hline Chemicals & 10.3 & 3.8 & 3.1 & 5.4 & 11.7 \\
\hline Fuel & 5.5 & 6.0 & 5.3 & 3.7 & 7.4 \\
\hline Short-term interest rate costs & 3.3 & 2.1 & 1.8 & 2.4 & 3.4 \\
\hline \multicolumn{6}{|l|}{ Fixed costs } \\
\hline Labour & 5.0 & 5.2 & 10.6 & 4.8 & 14.5 \\
\hline Land & 7.5 & 8.7 & 7.1 & 8.0 & 3.2 \\
\hline Machinery \& equipment & 45.3 & 51.7 & 51.1 & 50.1 & 40.8 \\
\hline Long-term interest rate costs & 14.9 & 17.1 & 16.9 & 16.7 & 12.7 \\
\hline Total share of capital & 18.3 & 19.2 & 18.6 & 19.4 & 16.1 \\
\hline
\end{tabular}

Source: $\quad$ Own presentation based on table 33.

Table 34 shows that interest rate costs account for roughly $18 \%$ of total production costs in Ukraine. If the real interest rate in 2001 were $1 \%$ point lower (e.g. $23.8 \%$ instead of $24.8 \%$ ), with other things remain constant, total production costs of all crops would have been roughly $0.7 \%$ smaller. Although above estimations should be applied with caution for agriculture as a whole, it can be stated that the changes of the interest rate does not yet significantly affects the farm profitability in Ukraine. For the farms that use less capital, effects of changes of the interest rate is even smaller. And for the farms that use more capital than assumed in tables 34 and 35 and that already invested into new modern machinery and equipment, changes of the interest rate become more sensitive.

Ukrainian farms do not attract substantial external financing. According to the annual reports of the Ministry of Agricultural Policy (1992-2000), which reflect the consolidated accounting reports of the large agricultural enterprises in Ukraine (except private farms and private households), over 1992-2000 the large farms almost fully relied on equity capital, while in external capital, the share of the banking credits was nil (table 35). In 2000, for example, Ukrainian large farms possessed four times more own equity capital than borrowed one. Although this ratio probably becomes smaller when fixed assets are estimated at market prices, the share of external capital in farm financing remains very low.

In 2001 and 2002 Ukrainian farmers gradually started to attract more credits from the commercial banks. Although the interest rate compensation program partially helped to direct more credits to the farms, other determinants such as farm restructuring, hard budget constraints, predictable agricultural policy, stable macro economy, were not least important (STRIEWE et al., 2001a). In 1999, the short-term credits to the farms were almost non-existent. In 2000, the enterprises of agricultural and food sector received UAH 1.8 bln of the short-term credits from the commercial banks, from which roughly UAH $818 \mathrm{mln}$ under the interest rate compensation scheme. In 2001, the volumes of short-term credits significantly increased and reached UAH 4.4 bln, including 
UAH 2.2 bln under the compensation scheme. And in 2002, the agri-food sector received UAH 4 bln credits with UAH 2 bln from them under the interest rate compensation scheme. The rates of interest rate compensation for farms varied from $50 \%$ of the NBU refinancing rate in 2000 to $70 \%$ in 2002 (DEMYANCHUK et al., 2002).

Table 35: The financing structure of the large farms in Ukraine, 1992-2000

\begin{tabular}{lccccccccc}
\hline & $\mathbf{1 9 9 2}$ & $\mathbf{1 9 9 3}$ & $\mathbf{1 9 9 4}$ & $\mathbf{1 9 9 5}$ & $\mathbf{1 9 9 6}$ & $\mathbf{1 9 9 7}$ & $\mathbf{1 9 9 8}$ & $\mathbf{1 9 9 9}$ & $\mathbf{2 0 0 0}$ \\
\hline \hline $\begin{array}{l}\text { Share of equity capital in total capital } \\
(\%)\end{array}$ & 83.2 & 80.6 & 60.7 & 83.7 & 92.5 & 89.1 & 84.2 & 80.8 & 77.6 \\
$\begin{array}{l}\text { Share of external capital in total capital } \\
(\%)\end{array}$ & 16.8 & 19.4 & 39.3 & 16.3 & 7.5 & 10.9 & 15.8 & 19.2 & 22.4 \\
$\begin{array}{l}\text { Share of short-term capital in total } \\
\text { external capital (\%) }\end{array}$ & 95.2 & 98.9 & 99.0 & 98.3 & 99.8 & 99.5 & 82.2 & 74.1 & 86.3 \\
$\begin{array}{l}\text { Share of bank credits in total external } \\
\text { capital (\%) }\end{array}$ & 38.3 & 16.0 & 35.0 & 16.0 & 13.0 & 7.0 & 3.7 & 3.1 & 2.2 \\
\hline Number of farms, thousand & 13.7 & 13.8 & 13.8 & 11.7 & 11.6 & 12.2 & 12.3 & 12.3 & 13.3 \\
\hline
\end{tabular}

Source: $\quad$ StRIEWE et al. (2001a: 55) and Ministry OF AGRICULTURAL POLICY OF UKRAINE (1992-2000).

How do the changes of interest rates affect the farm credit repayments? Let us consider the example of year 2001. In 2001, Ukrainian farmers received roughly $50 \%$ of all credits given to the agri-food sector (e.g. UAH $2.2 \mathrm{bln}$ ). The average maturity was half a year. The commercial bank real lending rate for farms equalled to $21.6 \%$ per year (with annual nominal interest rate of $29 \%$ and inflation of $6.1 \%$ ). Roughly UAH $1.1 \mathrm{bln}$ of the short-term credits were provided under the interest rate compensation scheme with the effective interest rate of $13.7 \%$ per year (under $70 \%$ compensation of the NBU refinancing rate). Assumptions on the interest rates do not held in reality, however, because the interest rate varies not only from farmer to farmer (see above), but also in respect to credit volume and maturity. Thus, below calculations should be treated with caution.

Based on these assumptions, at the end of 2001 the farmers had to repay UAH 2.2 bln principle plus UAH 388 mln accrued interest rate payments. If the market interest rate in 2001 were $1 \%$ point lower, with other things remaining constant, Ukrainian farmers would have paid UAH $366 \mathrm{mln}$ or $5.7 \%$ less for the use of credits. Totally, the costs of credit service (principle plus interest rate) would decrease by $0.9 \%$.

These rough calculations demonstrate the importance of keeping the interest rates low to encourage modernisation of Ukrainian agriculture. It is clear that there are many other determinants influencing long-term investments into the agriculture, and the interest rate is probably not the most important one (see section 2.4.1). But the interest rate cannot be ignored. Although the certain share of new investments can be financed by the own capital, the use of external financing is inevitably important to induce technical change and to sustain competitive position. Some farms can continue depleting their assets and remain profitable for several years, but in the long run most farms in Ukraine need urgent modernisation and thus, long-term investments. In that case, any increase of the capital costs would entail additional burden to service annual credit repayments. 


\subsubsection{Interest rate and storage}

Interest rates affect not only farm debts, but also the price formation of agricultural commodities. The theory of relationships between interest rate and storage costs was presented in section 2.4.4. Storage fulfils the important tasks of linking current and future agricultural prices. High storage costs usually 'encourage' farmers to sell products today instead of storing them and selling in the future (see equation 2.20 in section 2.4.4).

In spite of the evidence of excessive storage capacities in Ukraine, farmers are not inclined to store their commodities there. Over the last decade, most grain is sold during the first 2-4 months after the harvest. Farmers get lower prices compared to what they could receive from selling their grain later. Why farmers do not store their grain?

There are mainly four reasons, three of which are related to the interest rate. First of all, table 32 shows that the interest rates in Ukraine are high. In 2001, the real interest rate for credits equalled roughly $25 \%$. Hence, the opportunity costs of storing agricultural commodities are large. At the same time, difference between the deposit and credit interest rates remains substantial: in 2001 it equalled roughly $15 \%$. It means that the effective real deposit interest rate was only 5\% (UEPLAC, 2002). This situation significantly weakens the hypothesis of high opportunity costs in general, while leaving it strong for some farmers who are able to receive various interest rates.

Secondly, farmers sell their harvest so early since many of them have liquidity constraints. October and November are the months in which the farmers should repay their credits to input suppliers and commercial banks. The sale of agricultural commodities is often the only opportunity for many farmers to cover the debts on time. The higher the interest rate on the lending market, the greater are farmers' debts, and thus, the liquidity constraints are more binding.

Thirdly, the physical costs of storage are indirectly affected by interest rates. Storage is only one element of the long chain called 'marketing infrastructure'. Marketing was essentially a non-issue in the USSR. For example, realistic transport costs did not play a role in determining product movements and spatial price integration. Market infrastructure was adjusted to direct imports through Black Sea to the north-east of the country, etc. After ten years of transition, the low efficiency of marketing infrastructure remains an important constraint for economic growth. Marketing costs, both explicit and implicit, are excessively high (see section 3.2.6.1). Large long-term investments are required to modernise storage facilities and to re-adjust the infrastructure from import to export activities. However, high interest rates reduce investment activities, hamper the renovation of the storage facilities, and, thus, increase physical cost of storage.

Finally, uncertainty about future prices increases the risks of storing commodities and, thus encourages early sales. Policy makers are greatly responsible for this uncertainty. Interventions on the local level are sometimes pervasive, at any time grain movement can be banned by the regional authorities. Wide information dissemination of the price forecasts among farmers is rare. The lower the transparency of the policy tools used, the higher is the uncertainty.

To improve farm performance, the linkages of the interest rates with agriculture, therefore, cannot be neglected. Otherwise, the sustainable economic growth will be never 
achieved. The macroeconomics of an open economy urges that the policy makers have economy-wide, not sector specific vision. And the agricultural policy makers have either no excuse. 


\subsection{Agriculture and overall economic development in Ukraine}

While above sections show how sound macroeconomic policy can contribute to agricultural development and how macroeconomic disorder can hamper farm profits, this section, in contrast, deals with the effects of agriculture on the rest of the economy in Ukraine. The theoretical foundations of studying these effects are described in section 2.5. At the outset, the state of farm competitiveness in Ukraine is studied and the outcomes for overall economy are considered. Then, the impact of agriculture on macroeconomic stability is analysed by looking at its effects on budget, inflation, and total exports. Although this analysis does not cover all linkages mentioned in table 5, the major issues for Ukrainian economy are dealt with to a large extent.

\subsubsection{Competitiveness of Ukrainian farms}

The notion of competitiveness is complex and sometimes controversial. In the economic literature, there is no single definition of this term. A widely used definition is provided by FREEBAIRN (1986: 2): "Competitiveness is an indicator of the ability to supply goods and services in the location, at the time they are sought by buyers, at prices that are as good as or better than those of other potential suppliers, while earning at least the opportunity cost of returns on resources employed." First part of this definition considers 'logistic competitiveness', i.e., the ability of farmers to satisfy the needs of, for example, food processors, with respect to punctual deliveries or expected product quality. Second part of the above-definition deals with 'output price competitiveness', i.e., the ability of farmers to meet consumer requirements on both internal and external markets with respect to output prices. If certain farmer cannot supply his products at least at prevailing prices or lower, he can hardly be competitive in the long run, and, therefore, he has to leave the business. And third part of the definition of the competitiveness considers 'input use competitiveness', i.e., the ability of farmers to use employed resources efficiently. Third element is referred to the agricultural productivity. If the farmer meets the requirements of all three components of the definition of competitiveness, his activities positively contribute not only to agricultural development, but also to overall economic growth through the following channels:

- Competitive farmers ensure that downstream sectors enjoy high quality of agricultural raw commodities supplied on timely manner.

- $\quad$ Competitive farmers supply more food, while simultaneously reduce output prices. In this way the farmers directly improve consumers' welfare.

- $\quad$ Competitive farmers receive maximum gains from employing limited resources. They leave to other farmers and non-farmers more resources to use and they ensure high social returns on the resources used.

- $\quad$ Competitive farmers absorb more industrial inputs and pay bills on time.

Various indicators can be used to measure competitiveness. Among these indicators, Domestic Resource Cost (DRC) and the related Private Cost Ratio (PCR) are popular approaches in studying farm competitiveness in developing countries (MONKE 
and PERSON, 1989), as well as in CEE transition economies (BANSE et al., 1998; BANSE et al., 1999; BOJNEC, 1999). ${ }^{49}$ The DRC compares the opportunity cost of domestic production (e.g. the costs of using domestic primary resources - land, labour and capital) to value-added at border prices (TSAKOK, 1990):

$$
D R C_{i}=\frac{\sum_{j=k+1}^{n} a_{i j} V_{j}{ }^{s}}{P_{i}^{s}-\sum_{j=1}^{k} a_{i j} P_{j}^{s}}
$$

where $a_{i j}(\mathrm{j}=\mathrm{k}+1, \mathrm{k}+2, \ldots \mathrm{n})$ in the numerator are the technical coefficients for primary domestic resources and non-traded intermediary inputs (i.e. the amount of input $j$ required to produce one unit of output $i$ ), and $V_{j}^{S}$ are the social prices of these domestic resource and non-traded intermediate inputs. The $P^{S}$ are the border (or social) prices of either output $i$ or input $j$, while $a_{i j}(\mathrm{j}=1,2 \ldots \mathrm{k})$ in the denominator are the technical coefficients (units of input $j$ per unit of output $i$ ) for traded inputs.

Social prices are undistorted border market prices. For exported outputs and inputs, FOB export prices adjusted for marketing costs are used. For imported goods, CIF prices plus import tariffs adjusted for marketing costs are used (see equations (3.3) and (3.4) in section 3.2.6.4). The estimation of social prices of domestic factors is not straightforward. According to theory, primary domestic resources as well as non-traded intermediary inputs are estimated at the 'second-best' social price to represent the contribution of the resource at the margin (BOJNEC, 1999).

For DRC calculations the actual nominal exchange rate is used. The DRC is an indicator of the relative efficiency of producing a dollar's worth of value-added by the producer of a certain product. When the DRC is smaller than 1 , but still positive $\mathrm{e}^{50}$, domestic production is efficient and internationally competitive, because the opportunity cost of using domestic resources is smaller than the net foreign exchange gained from export or saved by substituting for imports. The opposite is true when the DRC is greater than 1.

The PCR is defined as the ratio of the opportunity cost of primary domestic resources and non-traded intermediate inputs to value-added at private (domestic) prices:

49 Another common indicator of international competitiveness is the Social Cost-Benefit Ratio. This indicator treats the costs of tradable and non-tradable inputs equally, which eliminates the possible bias in the DRC if tradable inputs and domestic factors are substantial substitutes among different types of farm (MASTERS and WINTER-NELSON, 2000). This indicator would be useful if we were comparing the competitiveness of large farms and private household plots in Ukraine. As we examine only large commercial farms, the inclusion of this additional measure generates no additional insights.

${ }^{50}$ The DRC is negative if the activity in question is value subtracting. 


$$
P C R_{i}=\frac{\sum_{j=k+1}^{n} a_{i j} V_{j}^{p}}{P_{i}^{p}-\sum_{j=1}^{k} a_{i j} P_{j}^{p}}
$$

where all terms are as in equation (4.23) and the superscript ' $p$ ' indicates that private prices are used instead of social ones. Since the PCR is measured at private (or actual) prices which are often distorted by different policy measures such as import tariffs or input subsidies, it can be compared with the DRC to determine the impact of distortions (taxation or subsidisation) on farm competitiveness.

The competitiveness of crop production in Ukraine is estimated on the base of above presented DRC and PCR ratios. The estimation covers six crop products for the period from 1996 to 2001: winter milling wheat, winter feed wheat, winter feed barley, corn, sunflower seeds, and sugar beet. ${ }^{51}$ The information of tradable inputs and domestic production factors are the same as in section 4.2.2, while data on social and private prices is presented in section 3.2.6.4. The results of the DRC and PCR estimations of Ukrainian farms on average are shown in table 36. The farms are neither competitive at world nor at domestic prices. At both prices, these farms use scarce resources inefficiently as the opportunity costs of using domestic resources is larger than the net foreign exchange gained from export or saved by import substitution. Although there are roughly $20 \%$ of 'best practice' farms in Ukraine which since 2000 became competitive in producing grains and sunflower seeds and greatly contributed to the economic growth over 20002002, the largest share of the farms remains highly inefficient (see ZORYA and VON CRAMON-TAUBADEL, 2002).

${ }^{51}$ These estimations are largely based on ZORYA and VON CRAMON-TAUBADEL (2002). 
Table 36: PCR and DRC for crop production in Ukrainian farms on average, 1996-2001

\begin{tabular}{lcccccc}
\hline & $\mathbf{1 9 9 6}$ & $\mathbf{1 9 9 7}$ & $\mathbf{1 9 9 8}$ & $\mathbf{1 9 9 9}$ & $\mathbf{2 0 0 0}$ & $\mathbf{2 0 0 1}$ \\
\hline \hline Winter milling wheat & 2.2 & 2.0 & 2.0 & 2.7 & 0.9 & 1.1 \\
Winter feed wheat & 6.0 & 4.1 & 5.6 & 4.8 & 1.7 & 3.5 \\
Winter feed barley & 3.3 & 2.5 & 4.8 & 3.7 & 1.0 & 1.5 \\
Corn & 1.2 & 1.7 & 3.4 & 3.0 & 1.1 & 1.3 \\
Sunflower seeds & 3.4 & 3.3 & 4.3 & 3.1 & 2.2 & 1.3 \\
Sugar beet & 2.0 & 2.2 & 2.9 & 10.1 & 2.4 & 3.0 \\
\hline \hline & 1.9 & 2.1 & 1.8 & 2.7 & 1.1 & 1.7 \\
\hline Winter milling wheat & 2.9 & 3.3 & 5.0 & 4.9 & 6.4 & 4.1 \\
Winter feed wheat & 2.6 & 2.4 & 3.8 & 4.0 & 2.0 & 1.6 \\
Winter feed barley & 1.2 & 1.5 & 5.1 & 3.3 & 1.5 & 1.4 \\
Corn & 2.1 & 1.9 & 2.2 & 2.3 & 1.2 & 1.8 \\
Sunflower seeds & 2.9 & 5.5 & 3.4 & 11.3 & 2.7 & 4.8 \\
Sugar beet & Domestic Resource Cost \\
\hline Source: & \multicolumn{7}{c}{ Private Cost Ratio } \\
\hline
\end{tabular}

Source: $\quad$ ZORYA and VON CRAMON-TAUBADEL (2002).

Above findings are confirmed by other studies for Ukrainian agriculture. VENEMA (2002) and SAUER (2002) studied the competitiveness of Ukrainian milk farmers and dairy industry. VENEMA (2002), using the methodology of the International Farm Comparison Network (IFCN) of Federal Research Centre in Braunschweig, Germany, found that two 'best practice' dairy farms in Ukraine showed much better profit performance and had much more competitive production cost structure than 'typical' German dairy farms. There are roughly $20 \%$ of such farms, while all others remain uncompetitive in producing milk (ZORYA et al., 2002). Although the inefficiency of the dairy industry, which translates into low milk purchasing price, was very important in this respect (SAUER, 2002), farm management issues described in section 3.2.4 and the agricultural policy of the GOU (see sections 3.2.5 and 3.2.6) were crucial determinants of low competitiveness.

Finally, farm competitiveness can be measured by changes in total factor productivity. Total factor productivity measures the growth in total output relative to the growth of total input use, in which the inputs are aggregated with appropriate weights (OSBORNE and TRUEBLOOD, 2002). Productivity growth stimulates exports by reducing per unit costs of production, thereby making domestic output more price competitive visa-vis imports and the world market - in other words, productivity growth generally improves a country's comparative advantage in the products in question. A number of studies found the evidence that the total factor productivity of Ukrainian farms had decreased over the transition period. LISSITSA (2002) measured the total factor productivity of the large farms in Kyiv Oblast of Ukraine during 1991-1999 and found that the total factor productivity of these farms annually decreased by $6 \%$. KURKALOVA and JENSEN (1996), as well as MUROVA (2000), supported the evidence of decreasing the total factor productivity of the large-scale Ukrainian farms over the different periods of time. 
Low competitiveness of Ukrainian agriculture has the following negative outcomes to the overall economic development of the country:

- Low farm productivity explicitly means that non-agriculture gets fewer resources as it could have got in the case of more competitive structure of the farming sector. They also produce less agricultural output that could be potentially supplied to the food processing industry. It means that 'weak' agricultural sector spills over its weaknesses to the up- and downstream sectors in Ukraine.

- Inefficient farms threaten the food security in the country through two channels: (a) they fail to supply agricultural output at lower prices, and (b) they diminish the economic growth in the country, subtracting the economic value (see also STRIEWE et al., 2001b).

- Uncompetitive cost structure of the farms in Ukraine 'presses' for more protection. Usually an increase of the farm protection is associated with increased import tariffs and non-tariff barriers (e.g. decreasing the openness rate of the economy) and/or with increase of domestic regulations (subsidies, debt forgiveness, tax exemptions) (e.g. increasing of the budget deficit and/or government expenditures). This inevitably leads to the social losses.

- The desire to protect farms in Ukraine is often associated with the stimulation of the domestic production of all agricultural inputs as well. To reach this goal, the GOU prohibits the import of new agricultural machinery and equipment, agricultural chemicals, and seeds in different ways (see section 3.1.4). This further hampers the overall economic growth since the use of the domestic resources is predetermined by either the GOU agencies or distorted price relations. Moreover, more jobs, for example, in the agricultural machinery manufacturing sector in Ukraine, due to the import protection of this sector, destroy many jobs on farms, because the farms could be forced to decrease their production due to resulting increased costs of using domestic machinery compared with modern Western models (VON CRAMON-TAUBADEL, 2002). As a result, even more unemployment as whole could result from the initiation of import protection.

\subsubsection{Agriculture and macroeconomic stability in Ukraine}

In addition to the effects of farm competitiveness on the rest of the economy, agriculture-specific policies can also affect the macroeconomy. The most distinctive effects are those on national budget, inflation and export stability. All these areas are of a paramount importance for the macroeconomics of the open economy. Moreover, they all are the key variables in the political debates in Ukraine, being the major tools to ensure economic growth and improve people's welfare.

\subsubsection{Agricultural subsidisation and budget deficit}

The structure and developments of the farm subsidisation in Ukraine were detailed analysed in section 3.2.5. Although the farms in Ukraine are not subsidised as intensively as in the Soviet times, even this level of subsidisation could burden the national budget. It also seems that if more revenue in the national and local budgets were available, farmers would have been supported even stronger. 
What are the wide-economy effects of farm subsidisation in Ukraine? In addition to the negative effects on efficient farms through allowing less efficient farm to remain in the sector and use limited resources, farm subsidisation affects the national budget in magnitudes shown in table 37.

Table 37: Farm support and national budget in Ukraine, 1998-2001

\begin{tabular}{lcccc}
\hline & $\mathbf{1 9 9 8}$ & $\mathbf{1 9 9 9}$ & $\mathbf{2 0 0 0}$ & $\mathbf{2 0 0 1}$ \\
\hline \hline Support of agricultural producers, UAH bln & 3.3 & 5.6 & 3.8 & 4.4 \\
Farm support as a share of total GDP, $\%$ & 3.2 & 4.3 & 2.2 & 2.1 \\
Farm support as a share of total budget expenditures, $\%$ \% & 8.7 & 12.7 & 6.0 & 6.2 \\
Actual budget deficit as a share of total GDP, $\%$ & -2.1 & -1.4 & 1.2 & 0.5 \\
\hline
\end{tabular}

Source: $\quad$ Own calculations based on table 17 and UEPLAC (2002).

During 1998-2001, farm support accounted for roughly $8 \%$ of the total budget expenditures with its peak in 1999. Its annual share in GDP equalled to 3\% in average. According to the IMF (2001), during 1998-2000 the GOU spent roughly 4\% of GDP on education and $3 \%$ on health care. Taking into account the importance of these latter sectors for human capital development and their public goods characteristics, the agricultural subsidies in Ukraine seemed to be extremely large for Ukrainian economy (measured by GDP value). Moreover, without the farm support and with other things remain constant, Ukraine would not have had the budget deficit in 1998 and 1999. These results support the findings of LEGEIDA (2001), who states that the agricultural sector is among the largest net beneficiary in Ukrainian economy.

In addition to the explicit effects on the budget, the farm subsidisation affected the RER through the fiscal deficit. The results of above econometric estimations of the RER show that a $1 \%$ increase of the budget deficit, with the monetary base remaining constant, induces $0.74 \%$ of a RER appreciation in the short run. In 1999, for example, with 'zero' level of farm subsidisation, the RER would have been 3\% lower. Agriculture as a sector producing mainly tradable goods could certainly have gained from that lower RER.

While the impact of the subsidies per se on budget balance is more or less visible, the way, in which these subsidies were provided, implicitly contributed to the fiscal disorder via the negative impact on agribusiness and commercial banks. In section 3.2.5 it was said that Ukrainian state itself encouraged bad payment discipline of the farms. Until 2000, the GOU set the 'soft budget constraints', allowing farms to accumulate budget loan debts and not to pay taxes. Moreover, during 1996-1999 the GOU regularly insisted that farms had to pay state debts first, greatly discriminating against the private creditors of Ukrainian agriculture.

Bad payment discipline of farms negatively affected the 'national balance sheet through two mechanisms: (a) an increase of the share of non-performing loans, and (b)

\footnotetext{
${ }^{52}$ This is not the actual expenditures from the budget. As mentioned in the dissertation, the most farm support comes from the tax exemptions, not direct budget spending. But this is two sides of the same coin; either you get lower budget income or you increase you budget expenditures - an impact on the budget is similar.
} 
the vulnerability of currency mismatches and loan maturity. These mechanisms are explained in ZORYA (2001a: 47): "Non-payment by farms diminishes the liquidity of private input suppliers and the state. Furthermore, the private suppliers and banks that suffer from non-payment are less able to pay taxes, increasing deficits and forcing the state to borrow abroad or from already 'weakened' domestic banks. As non-payment proliferates, the maturity and currency composition of debt worsens: private suppliers could obtain only short-term credits and often only in foreign currency, and the state has to raise real interest rates to attract the funds it required to finance its spending".

After 2000, the situation with farm payment discipline substantially improved. The GOU set 'hard budget constraints' and withdraw itself from the input supply market. In the absence of state input supply, the farmers had only one effective alternative: try to attract the capital from distrustful commercial banks and input suppliers. Although it is very difficult to distinguish these effects on Ukrainian budget from other effects, the importance of better farm payment discipline is obvious. The improved budget situation certainly entailed a decline of interest rates, lower inflation, and higher monetisation of Ukrainian economy (see, for example, IER, 2002).

\subsubsection{Agriculture and inflation}

High inflation creates uncertainty which discourages businesses from expanding their activities and investing for the future, and thereby prevents economic growth. Although there are still hot academic discussions about the optimal inflation rates and their impact on economic growth, the consensus about negative influence of high inflation is reached (DORNBUSCH et al., 1998: 142-150). HAVRYLYSHYN et al. (1999: 42) suggest that "inflation levels higher than the range of 20-30\% significantly hurt growth" in CEE transition economies. CHRISTOFFERSON and DOYLE (1998) find the threshold to be much lower (13\%). Hence, it is highly probable that until 2001 inflation in Ukraine negatively affected its economic growth, being much higher than $13 \%$ (see table 38 ). ODLING-SMEE (2001), for example, stated that "low inflation was a precondition for the resumption of positive rates of economic growth after the initial output collapse of the early 1990s." The growth of the food (and agricultural) prices was among the main sources of the inflation. According to the StATE STATISTICS COMMITTEE OF UKRAINE (2001b), the share of the food price index in total CPI accounts for $64 \%$, substantiating the overriding role of the food price changes in determining country's inflation level.

\footnotetext{
${ }^{53}$ Term 'national balance sheet' is intensively used in the discussions on financial crisis in the emerging economies. It means the financial balance of all economic actors in the national economy, i.e. state and private sector.
} 
Table 38: Structure of consumer price index in Ukraine, 1997-2001, (in \% to previous year, at end of year)

\begin{tabular}{rrrrrr}
\hline & $\mathbf{1 9 9 7}$ & $\mathbf{1 9 9 8}$ & $\mathbf{1 9 9 9}$ & $\mathbf{2 0 0 0}$ & $\mathbf{2 0 0 1}$ \\
\hline \hline Consumer price index, total & 10.1 & 20.0 & 19.2 & 23.3 & 6.1 \\
Food & 14.1 & 22.1 & 26.2 & 28.4 & 7.8 \\
Non-food & 2.9 & 24.1 & 10.6 & 8.9 & 0.2 \\
Services & 7.9 & 13.0 & 11.9 & 31.2 & 5.3 \\
\hline Agricultural price index (GAO deflator in 1996 prices) & 14.4 & 19.1 & 22.4 & 29.8 & 15.8 \\
\hline
\end{tabular}

Source: $\quad$ MINISTRY OF ECONOMY OF UKRAINE (2001) and UEPLAC (2002).

Sources of agri-food inflation in Ukraine are closely related to the pervasive import protection described in section 3.2.6.2. Being a 'closed economy' in terms of food imports, the farms meet no or very weak international competitiveness pressure, which allows them to artificially increase output prices. ${ }^{54}$ This also ensures that many Ukrainian farms receive profits at the expense of consumers, and remain uncompetitive at the world market prices. Moreover, even under high import protection, farmers are unable to satisfy domestic demand, which additionally increases the agricultural and food prices. Only within 2001 the average farm-gate prices for sunflower seeds increased by $55 \%$, for sugar beet and vegetables by 24 and $20 \%$ correspondingly. Prices for livestock products grew almost twofold (SSCU, 2001a). As this price situation is combined with low efficiency of the whole food chain and the monopolistic position of many food processors in Ukraine (see, for example, SAUER, 2002 on inefficiency of dairies in Ukraine), changes in agricultural prices almost completely transmitted into changes in food prices, with the exception of 2001 (see table 38). The effects on total CPI over the observed period were large indeed. A growth of population's income that occurred in recent years will probably continue to push the food inflation index up until human food requirements are satisfied.

One can argue that the agricultural prices in Ukraine are still reaching world market prices. This natural process of transition from low administered prices to higher market ones will stop at certain moment and this source of inflation in Ukraine will disappear. But the reality is different. In 2001, farm-gate prices in Ukraine for major agricultural products already reached the world market level, and the prices for some of them (e.g. sunflower seeds and sugar beet) even exceeded it (see table 21). Actually, Ukrainian farmers failed to ensure a large supply of the agricultural products at lower agricultural prices, contributing in this way to the food security and sustainable economic development of the country.

\subsubsection{Agriculture and export stability}

Agricultural exports seriously affect total trade balance of Ukraine. During 19962001, the share of agri-food exports in the total merchandise exports equalled roughly

\footnotetext{
${ }^{54}$ It is true that Ukraine exports most agricultural products, but it imports highly processed foodstuffs. Without high import tariffs, Ukraine would certainly have imported more, for example, dairy and meat products. Import protection 'helps' domestic farmers by stimulating production of import substitutes in Ukraine with consecutive positive outcomes to the demand for raw agricultural products.
} 
$12 \%$ (see table 16). Many experts argued that at least until recent years the agricultural potential in Ukraine was not fully realised (see ZORYA and VON CRAMON-TAUBADEL, 2002), and that losses from this under-utilisation are substantial. How large are the losses in Ukraine?

To answer this question, development of grain and sunflower seed exports will be considered in turn. Figure 39 shows the net grain export from 1996/97 to 2002/03 marketing years. With exception of 1998/99 marketing year, over 1996-2000 Ukraine exported not more than 2 mln tons of grain per year. In 2001, country's grain export grew to $9 \mathrm{mln}$ tons and in 2002/03, export is expected to increase to $10-12 \mathrm{mln}$ tons.

Figure 39: Net grain export in Ukraine, 1996/97-2002/03 marketing years, (in mln tons)

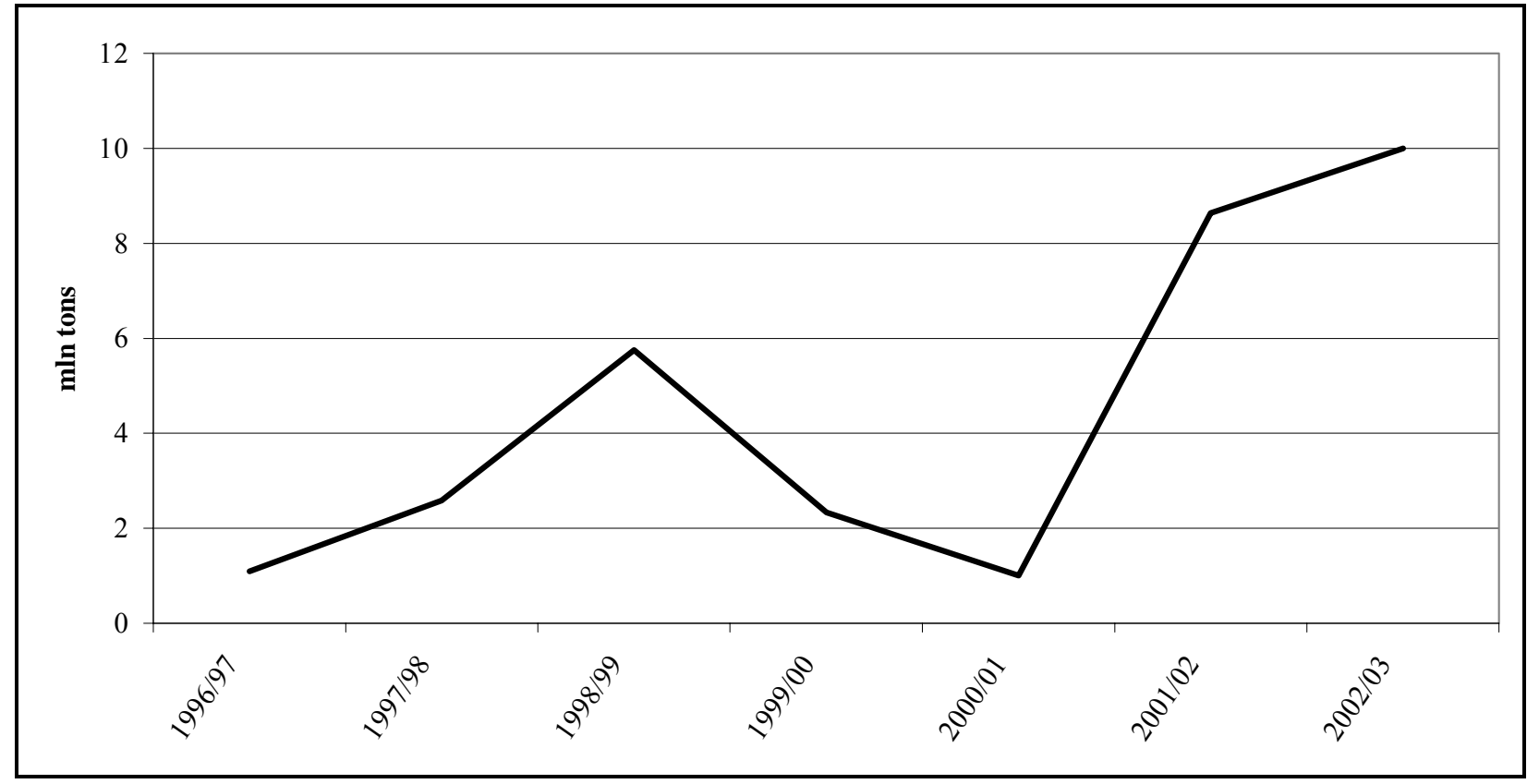

Note: $\quad 2002 / 03$ marketing year is the forecast of the UKRAGROCONSULT.

Source: $\quad$ UKRAGROCONSUlt (2001-2003).

This is true that favourable weather conditions in recent years helped to boost grain harvests. However, the importance of farm restructuring and policy changes do not have to be underestimated. The policy failures and their negative outcomes during the transition period are thoroughly discussed in section 3.2. If we assume that the weather accounts for roughly $2 \mathrm{mln}$ tons of grain export annually, ${ }^{55}$ the average 'potentially' foregone grain export during 1996-2000 equals at least $5 \mathrm{mln}$ tons per year. Annually Ukrainian farmers under-received $\$ 500 \mathrm{mln}$. As a result, during 1996-2000 the total merchandise export was annually lower by roughly $3.4 \%$, while the deficit in merchandise trade could be al least one third less.

\footnotetext{
${ }^{55}$ MACOURS and SWINNEN (2000) econometrically measured the contribution of various reform policies and developments to the production drop of the agricultural output of five crops in eight CEE countries during 1989-1995. They found that weather changes explained only $10 \%$ of the output decline. In Ukraine, unfavourable weather appears once per 3-4 years on average.
} 
The development of sunflower seeds exports was quite opposite. Until 1999, Ukraine exported around $40 \%$ of produced sunflower seeds, mainly to the Western Europe. In 1997 and 1998, the revenue from sunflower seeds exports equalled to 1.5\% of the total merchandise exports (SSCU, different years). Sunflower seeds were the major cash crop of Ukrainian farmers at that time (VON CRAMON-TAUBADEL and STRIEWE, 1999). However, in 1999 the GOU set 23\% export tax, reducing this rate to $17 \%$ in 2000 . As a result, the export of sunflower seeds decreased by more that one-half: from $\$ 210$ mln in 1997 and 1998 to $\$ 100$ mln per year in 1999 and 2000. When the lower sunflower seeds export receipts in 1999, for example, are added to the foregone export revenue from no export of grain, the total impact on merchandise export would reach $3.8 \%$. This is true that the export tax has encouraged fuller capacity utilisation of domestic crushers, and allowed Ukraine to export more sunflower oil instead. But this is also true that Ukrainian farmers got lower price for their seeds that discouraged them to produce more seeds for export. ${ }^{56}$ Similarly important is the fact that in a situation with a prohibitive export tax, domestic crushers become freed from taking urgently needed restructuring measures, and in the long run it is not clear at all whether oil processors are able to substantially increase oil exports.

The problems with agri-food export are related not only to underproduction of agricultural products. As spelled the section 3.2.6.1, agricultural exports are hampered by high export marketing costs, inter-regional trade barriers, export taxes, and nonmembership in the WTO. For example, the latter creates uncertainty concerning the long-

${ }^{56}$ In 2002, the production of the sunflower seeds actually increased to $3 \mathrm{mln}$ tons compared with $2.3 \mathrm{mln}$ tons in 2001. The defenders of export tax were happy to argue that in reality export tax did not discourage seed production. However, this statement, based only on one year, is completely misleading, because in 2001 Ukrainian farmers greatly reduced seeds production (from $3.5 \mathrm{mln}$ tons in 2000 to $2.3 \mathrm{mln}$ tons in 2001), reacted in this way to the introduction of export tax. Due to seed deficit in 2001, domestic seed prices jumped from UAH 500 per ton in 2000 to UAH 800 per ton in 2001. In 2002, the farmers reacted to that price increase very quickly. But what would be domestic price of the seeds in Ukraine in 2001 without export tax? At least 17\% higher or UAH 940 instead of UAH 800 per ton? Certainly, yes. The farmers would gain at least UAH $322 \mathrm{mln}$ if the export tax were removed, and they would probably produce more than $3 \mathrm{mln}$ tons. 
term access of Ukrainian products to certain foreign markets, including the EU. If these constraints remain, it is hard to expect any improvements of farm performance, and thus, higher export receipts.

Finally, it is important not to forget the invisible effects of fluctuations of agrifood exports. As the sum of agri-food export and imports amounts for roughly $20 \%$ of the total merchandise goods turnover, any significant changes in agri-food trade will influence the total rate of openness of the economy to international trade. In turn, this will affect the real exchange and interest rates with negative consequences for agricultural sector. Until Ukraine's current account becomes less dependent on agri-food foreign trade, this issue should be seriously taken into account. 


\subsection{Summary of the chapter}

The empirical results prove an importance of considering the agricultural development in Ukraine in the context of overall economic development. Sector-specific 'privileged' agricultural policy is often countervailing, damaging agricultural growth more than the policy makers can expect. In the long run, an efficient agricultural sector can be realised only in a co-existence with developed non-agriculture and visa versa.

The econometric analysis demonstrates that during 1996-1998 the RER in Ukraine was overvalued with its peak in 1997 (16\% on year average). In 1999-2000 the RER was largely undervalued, while within 2001 the equilibrium of the RER was restored. Agriculture was affected by these developments in the RER. During the observed period, macroeconomic policy indeed affected the agricultural incentives in Ukraine at least so strongly as the agricultural policy itself. The average rate of the direct nominal protection for exportable farm products equalled $-4.9 \%$, while the indirect nominal rate of protection was $-5 \%$. Furthermore, over 1996-2001 the RER misalignment also negatively affected the growth of agricultural output in Ukraine.

Similarly to the exchange rate, the interest rate also plays an important role in the agricultural development. Together with other factors, high interest rates throughout the whole transition period seemed to be a substantial impediment to the modernisation of Ukrainian agriculture. First, the interest rate indirectly affected farmers through its comovements with the RER. Sharp increases of the real interest rate in Ukraine were often associated with unsustainable RER appreciation and correspondent negative double effects on farm competitiveness. At the same time, a gradually declining interest rate and a stably balanced exchange rate were certainly among the important determinants of the recent recovery of agriculture.

Due to many reasons, Ukrainian farms make little use of commercial credits. Until recent years, therefore, the fluctuations of the interest rate did not significantly influence farm production costs. However, this situation slightly improved in recent years, and the farmers, attracted short-term credits, and became quite sensitive to changes in the interest rate. Rough calculations for 2001 demonstrate that $1 \%$ point increase of the interest rate could additionally burden farm debts on interest rate payments by $5.7 \%$. As more farms start to use longer-term credits to modernise its machinery and equipment, sharp interest rate changes will certainly add liquidity constraints and, thus, slow down the investments activities in the agricultural sector.

Finally, the interest rate affects the storage costs and thus, price formation of the agricultural commodities. High interest rates greatly contributed to the low storage activities in Ukraine, increasing farmers' opportunity costs of storing, their liquidity constraints, and physical cost of storing. Hence, efforts of the GOU to increase farm-gate prices should be inevitably targeted to creation of better macroeconomic conditions, favourable investment climate and, thus, lower interest rates.

Agriculture is an important sector of Ukrainian economy in terms of its contributions to total GDP, balance of payments, and employment. Hence, it significantly affects overall economic development and to a large extent it is responsible for both macroeconomic disorder during the long period of transition and recent economic growth. According to the DRC, IFCN and productivity analyses, most Ukrainian farms 
remain uncompetitive. As a result, the market for industrial goods is weaker, the financial sector is threatened by low investment opportunities in the agriculture, food security of the country is in danger, and higher farm protection is a probable reaction. In context of macroeconomic stability, farm subsidisation in Ukraine during 1998-2001 caused serious problems for the fiscal budget's management, accounting for around 3\% of GDP per year. Finally, agricultural sector disequilibrium greatly contributed to the inflation growth and export vulnerability in Ukraine. 


\section{Summary and Conclusions}

This last chapter summarises the important results of the dissertation and discusses the policy implications for considering the agricultural development in an overall economics context. And finally, it discusses the future research agenda.

\subsection{Summary of the dissertation}

The economics of the open economy is complex: this message appears everywhere in the dissertation. The interlinkages between agriculture and macroeconomics should be clearly understood, otherwise the market will penalise persistent temptation of their ignorance. Chapter 2 offers the theoretical foundations of studying the effects of macroeconomic policy on agriculture. The Dependent Economy Model and the MundellFlemming Model demonstrate the interdependencies in the economy, emphasising both opportunities and constraints for various policy instruments to achieve the planned targets. Among many macroeconomic variables, the real exchange and interest rates are especially distinctive with respect to agriculture. They affect agricultural incentives, farm production costs, debts or land prices. Broad world-wide literature and experience suggest that those impacts could be significant, and that as soon as agriculture-specific problems are settled and institutions are in place, the agricultural development becomes more and more dependent upon overall economic policy.

Above theoretical framework allows not only to consider the impact of the real exchange and interest rates on agriculture per se, but also to discuss the role of agriculture itself in determining these variables. The second part of the theoretical chapter, therefore, deals with the role of agriculture in an overall economy in the philosophy of the development economics. The magnitude of these effects certainly hinges on the importance of the farming sector in terms of GDP generation, employment or balance of payments. In Ukraine, where the agriculture is an important part of the national economy, these effects are especially significant.

To quantify these relationships in Ukraine, chapter 3 analyses the transition of Ukrainian economy from a centrally planned to a market economy. The overall development in Ukraine is linked to various macroeconomic policies. The early period of transition was characterised by serious macroeconomic mismanagement due to loose fiscal policy, inconsistent exchange rate regime, slow structural reforms and low level of trade liberalisation. This period ended up with the severe financial and banking crisis in September 1998. In the aftermath of this crisis, the macroeconomic policy became more in tuned with the requirements of the open economy. And the economy reacted quickly to these positive incentives. Between 2000 and 2002, the real GDP grew roughly 19\%, while in the first period it declined $74 \%$.

Agricultural output followed the trends of the overall economy. Similar to other sectors, the government failures played an important role in these developments. At the outset of transition, the reform of the agricultural sector was certainly not an easy task, taking into account severe structural distortions of the Soviet agriculture. However, instead of resolving real causes of farm inefficiencies and distortions, and going through 'creative destruction', the policy makers moved in the direction of preserving the old structure of agricultural enterprises, setting the soft budget constraints, continuing strong 
interventions in input and output markets, and greatly limiting the role of the private sector. As a result, agricultural output substantially contracted, and the farms remained largely inefficient.

In 2000, the GOU initiated far-reaching structural reforms in the agricultural sector, withdrawing itself from input and output markets, setting hard budget constraints and making farm support policy more transparent. Farmers responded relatively quickly to the improved business environment. Use of substantial internal reserves allowed many farms to greatly increase their efficiency, but much remains to be done to sustain farm competitiveness in the long run.

How large was the influence of the macroeconomic policy on Ukrainian agriculture and how did changes in farm performance affect the rest of the economy during the observed period? Chapter 4 tries to answers these questions. The econometric analysis of the RER helped to identify the periods of the RER misalignments. These misalignments, together with the policy of import protection for industrial products, greatly affected the agricultural incentives. During 1996-2001, the direct rate of nominal protection of exportable agricultural products in average equalled roughly $-5 \%$. Indirectly, the agricultural incentives were similarly taxed. In some years, the indirect taxation even exceeded the impact of the agricultural policy itself. Finally, the errorcorrection model showed that the RER misalignment hampered the agricultural growth.

Similar to the exchange rate, the interest rate also played an important role in the agricultural development. Together with other factors, high interest rates throughout the whole transition period seemed to be a substantial impediment to the modernisation of Ukrainian agriculture. High interest rates together with other credit-constraining factors limited the farmers' access to all types of credit, especially long-term credits. Steep interest rates also inflated 'storage costs', causing farmers sell their products at low prices. Finally, the interest rate indirectly affected farmers through its co-movements with the RER. Sharp increases of the real interest rate were often accompanied by unsustainable RER appreciation and correspondent negative double effects on farmers. At the same time, gradually declining interest rates with a stable exchange rate were certainly among the important determinants of recent recovery of the sector.

Taking into account the large contributions of Ukrainian agriculture to total GDP, balance of payments, total employment and rate of inflation, its developments could not remain unnoticed by the non-farmers. According to the various studies, most farms in Ukraine were found to be uncompetitive. As a result, the up- and downstream sectors are under-supplied and under-served, the banking sector is threatened by low investment opportunities in agriculture, food security is of concern, and higher farm protection is a reaction. Recent improvements in farm competitiveness spilled over positively on the rest of the economy, but further reforms are urgently needed to sustain the improvements.

In context of macroeconomic stability, farm subsidisation seems to have caused serious problems with fiscal management, especially in the years of budget deficit. In addition, it indirectly contributed to the RER misalignment and worsened the financial position of input suppliers and banks which worked with the farmers. Finally, during the whole transformation period an agricultural inflation greatly determined the total rate of inflation and increased total export vulnerability. With the farming sector remaining 
important to the economy, those effects are dangerous to ignore if the sustainable economic development of the country remains a long-term goal.

\subsection{Conclusions and policy implications}

After ten years of economic transformation in Ukraine, one can hardly conclude that the transition from a centrally planned to a market economy is successfully completed. Recent economic growth and solid improvements in farm performance brought on great euphoria concerning the prospects of Ukrainian economy. However, much still remains to be done to complete the transition on the one hand, and to prepare the economic actors and the state to adjust to new challenges in the era of globalisation on the other hand. Therefore, it is a high time to learn as much as possible from own and word-wide mistakes and achievements to ensure Ukraine's long-term sustainable development. What are the conclusions that can be drawn from this dissertation?

Firstly, the policy makers should respect the requirements of the open economy. The open economy is a complex system with dozens of interlinkages, often invisible and mainly non-linear. If the government, for example, wishes to encourage internal demand by increasing fiscal expenditures, it should not forget that under certain circumstances this increase may cause higher inflation, steeper interest rates, and a lower exchange rate. It means that an increase of real demand could be effectively neutralised by contra-effects of fiscal expansion. Similarly, structural reforms in the energy sector, for example, may not only increase budget incomes, but spill over the positive effects on other macroeconomic variables.

Secondly, agriculture is a part of Ukrainian economy. Farmers contribute to overall GDP, current account, capital flows and employment. At the same time, the agricultural sector consumes industrial goods and services. It receives state subsidies and private investments, and the agricultural products are either consumed domestically or exported. Thus, it is irresponsible to consider the agricultural development in the narrow sectoral framework.

Thirdly, the macroeconomic policies, therefore, are very important for agricultural development. Especially distinctive in this respect are the exchange and interest rates. They absorb all internal and external shocks in the economy and, therefore, to a large extent, reflect the quality of economic policies. These variables affect the agricultural growth through relative prices, farm production costs, farm debts, storage costs and land prices. Often the impact of these variables on farmers is even larger than the impact of the agriculture-specific policies.

Fourthly, the agricultural policies can greatly affect non-agricultural sectors and macroeconomic variables. If the policy makers use distortive policy instruments to protect farmers, for example, these instruments could entail negative outcomes for macroeconomic stability and economic growth as a whole. Consequently, the feedback from lower growth in non-agriculture and macroeconomic disorder could neutralise any government actions to effectively 'protect' farmers.

And lastly, the completion of transition of Ukrainian economy from a centrally planned to a market economy is of paramount importance. But parallel to this process, the policy makers and economic actors continuously face new challenges in the era of 
globalisation. Globalisation is unavoidable and it undeniably provides opportunities for transfer of technology, investment and economic growth. At the same time, globalisation sets new constraints for effectiveness of certain policy tools. The world is changing, and there is no guarantee that what worked in the past will work in the future. In this situation external shocks could greatly affect the domestic economy if it is not flexible enough (see IER, 2002). In a more global world, structural reforms should be a priority, policy interventions should be minimised and stable macroeconomic conditions should become a norm. In this situation, the interdependencies described in this dissertation are worth even more attention than before.

\subsection{Future research agenda}

This dissertation represents the first attempt to describe economic interrelations in Ukraine in respect to the agricultural sector. Although many questions were answered, many issues certainly remain either unresolved or even untouched. Ukrainian economy goes through dramatic structural changes. Data, on which the economic analysis in this dissertation is based, is still unreliable. Often the data exists only for the short periods of time, or does not even exist at all. The relationships between economic agents remain unstable and sometimes unpredictable, often due to the pervasive state interventions in the markets and private decision-making. As time goes by, the first task in the future research agenda, therefore, will be to re-estimate the interdependencies between agriculture and macroeconomics using the theoretical framework and empirical methods presented in this dissertation. The RER misalignment index, its impact on agriculture in a more sophisticated growth model, the effects of the interest rate on farm competitiveness, and the relationships between the real exchange and interest rates are among major topics, deserving special attention in future research.

Secondly, the impact of the interest rate on agricultural land prices was described only in theory. As the sale and purchase of agricultural land will be permitted in 2005, the price formation for agricultural land will become an important issue in Ukraine. Later on, therefore, this issue is worthwhile to be studied to shed light on linkages between interest rates, liquidity constraints, land prices, and land rents.

Thirdly, as soon as the sustainable developments in Ukraine's economy become a norm and the market mechanism - even if constrained by government interventions will have a dominant role in allocating resources, the interlinkages could be studied by the CGE model. The CGE model will improve our understanding of various transmission mechanisms and multipliers in the economy. It will also allow studying many other relationships, not empirically investigated in this dissertation.

Fourthly, various econometric models can also be used to study the interlinkages between agriculture and macroeconomic policy. For example, vector autoregressive (VAR) models are popular tools in considering these interlinkages in the developed economies (IN and MOUNT, 1994; SCHMITZ and HofFMANN, 1996; KUHL, 1998; KAABIA and GIL, 2000). The VAR models require qualitative and long time series, but as soon as they are available, the short-term effects of a shock in one variable (e.g., the money supply) on the agricultural and other macro variables can be analysed (using the impulse response function). This information is very useful in designing short-term policy targets. 
Although much remains to be done to shed the light on the interdependencies between agriculture and macroeconomics in Ukraine, I hope that this dissertation can serve as a good basis for improving policy making in the country and for drafting the future research agenda. 


\section{References}

ACU (2000): Results of Control and Analysis of the State of Pay Back of the Budget Loans Received the Farms in 1994-1999. Accounting Chamber of Ukraine, Issue 3 , February.

Agritrade (2002): Save or Spend? Reform of the Common Agricultural Policy. Press Release, www.agricta.org.

AgriUkraine (2002): Private Credits to the Farms in Ukraine. The News Agency, 04.04.2002, www.agriukraine.com.

AHT (2002): Strategic Objectives for Ukraine: Negotiation Process Ukraine-WTO: Results and Perspectives. Devoted to the New Political Elite. AHT Consulting Group, Agency of Humanitarian Technologies, http://aht.org.

AKIMOVA, I. (2001): Export Orientation and its Impact on Firm Restructuring in Ukraine. In: HofFMAN L. and F. MOELLERS (eds.): Ukraine on the Way to Europe. Heidelberg: Physica-Verlag: 206-223.

Aslund, A. (1999): Problems with Economic Transformation in Ukraine. Carnegie Endowment for International Peace.

Aslund, A. (2002): Why Has Ukraine Returned to Economic Growth? Institute for Economic Research and Policy Consulting, Working Paper No. 15, July, Kyiv.

BAFFeS, J., I. ElbadAWI and S. O'CONNEL (1999): Single-Equation Estimation of Equilibrium Real Exchange Rate. In: HINKLE L. and P. MONTIEL (eds.): Exchange Rate Misalignment: Concepts and Measurement for Developing Countries. Oxford University Press: 405-461.

BANSE, M. (2000): Macroeconomic Implications of EU Accession. In: TANGERMANN S. and M. BANSE (eds.): Central and Eastern European Agriculture in an Expanding European Union. CABI Publishing: 133-156.

Banse, M., T. Bargel, M. Gorton, J. Hartell, G. Hughes, J. Kockler and W. MuENCH (1999): The Evolution of Competitiveness on Hungarian Agriculture: From Transition to Accession. Working Paper Series of the Joint Research Project: Agricultural Implications of CEEC Accession to the EU, Göttingen.

BANSE, M., W. GuBA and W. MuENCH (1998): Eastern Enlargement of the EU: How Competitive Is the Agro-Food Sector in Central Europe under EU Conditions? The Example of Hungary and Poland. Institute for Agricultural Economics, University of Göttingen. Paper for presentation at the EAAS/ISHS Conference "Understanding Competitiveness" on April 22-24, 1998 in Apeldoorn, the Netherlands.

BARRO, R. and X. SALA-I-MARTIN (1995): Economic Growth. New York: McGraw-Hill.

BAUTISTA, R., S. RoBinson, F. TARP and P. WOBST (1998): Policy Bias and Agriculture: Partial and General Equilibrium Measures. IFRPI, Trade and Macroeconomic Division Discussion Paper No. 25.

BAutista, R. and A. VAldes (1993): The Bias against Agriculture: Trade and Macroeconomic Policies in Developing Countries. IFPRI.

BegG, D. and C. Wyplosz (1999): Why United Hands Are Fundamentally Better. Fifth Dubrovnik Conference on Transition Economies. Dubrovnik. 
BENECKE, C. (2000): Langfristige Wettbewerbsfähigkeit der Zuckerrübenproduktion in der Ukraine. Master Thesis at Department of Agricultural Economics, Göttingen University.

Berengaut, J., E. De Vrijer, K. Elborgh-Woytek, M. Lewis and B. Lissovolik (2002): An Interim Assessment of Ukrainian Output Developments, 2000-01. IMF Working Paper No. 97.

Berg, A., E. Borenzstein, R. SAHAy and J. Zettelmeyer (1999): The Evolution of Output in Transition Economies: How Different Is the FSU? IMF Working Paper No. 73.

BeVERIDGE, S. and C. NiLSON (1981): A New Approach to Decomposition of Economic Time Series into Permanent and Transitory Components with Particular Attention to Measurement of the 'Business Cycle'. Journal of Monetary Economics, Vol. 7: 151-174.

Block, S. and P. Timmer (1997): Agriculture and Economic Growth: Conceptual Issue and the Kenyan Experience. HIID Development Discussion Paper No. 498.

BOFINGER, P. (2001): Monetary Policy: Goals, Institutions, Strategies, and Instruments. Oxford University Press.

BojneC, S. (1999): The Competitiveness of Slovenian Farms and Food Processing Activities. Agrarwirtschaft 48, Heft 8/9: 295-303.

BojneC, S., W. Muench and J. F. M. Swinnen (1997): Exchange Rate and the Measurement of Agricultural Price Distortions in CEEC's and of CEEC-EU Accession Costs. Policy Research Group, Department of Agricultural Economics, Katholieke University Leuven.

Borges, A. (1986): Applied General Equilibrium Models: An Assessment of their Usefulness for Policy Analysis. OECD Economic Studies No. 7: 7-43.

Boss, H. (2000): Ukraine Economy: Past and Present. The Vienne Institute for International Economic Studies WIIW.

BRADA, J. (1998): Introduction: Exchange Rates, Capital Flows, and Commercial Policies in Transition Economies. Journal of Comparative Economics, Issue 26: 613-620.

BRANDES, W. and M. ODENING (1992): Investitionen, Finanzierung und Wachstum in der Landwirtschaft. Stuttgart: Ulmer.

BrooKs, K. (1993): Challenges of Trade and Agricultural Development for East/ Central Europe and States of the Former USSR. World Bank, University of Minnesota.

Buchs, T. D. (1999): Financial Crises in the Russian Federation: Are the Russian Learning to Tango? Economics in Transition, Vol. 7, Issue 3: 687-715.

BugRIY, M. (2002): Banking Sector of Ukraine is Hardly under Changes. Agency of the Business Information "Context", May 28, 2002, www.context-ua.com.

CHAI, C. (1995): Rural Human Capital and Economic Growth in Developing Countries. Senior Honours Thesis, Department of Economics, Harvard University.

ChAMBERS, R. and R. JUST (1981): Effects on Exchange Rate Changes on U.S. Agriculture: A Dynamic Analysis. American Journal of Agricultural Economics, Vol. 63: 32-46. 
CHApKo, I. (2000): Agricultural Enterprise Dept in Ukraine: Dept Structure, Accumulation, and Alternatives for Settlement. Iowa State University, Ukrainian Agricultural Policy Project.

Christofferson, P. and P. DOYLE (1998): Output, Inflation, and Stabilisation in Transition 1990-97. IMF Mimeo.

ClARK, P. and D. MACDONALD (1998): Exchange Rates and Economic Fundamentals: A Methodological Comparison of BEERs and FEERs. IMF Working Paper No. 98.

Clark, P. and D. MACDONALD (2000): Filtering the BEER: A Permanent and Transitory Decomposition. IMF Working Paper No. 144.

CONTEXT (2002): Economic Preconditions for Decline of Credit Interest Rates Do Not Still Exist. Agency of Business Information "Context", 17.04.2002, www.contextua.com.

Corden, W. M. (1997): Trade Policy and Economic Welfare. Oxford University Press.

Cottani, J., D. Cavallo and M. S. Khan (1990): Real Exchange Rate Behaviour and Economic Performance in LDCs. Economic Development and Cultural Change, Vol. 39: 61-76.

Cramer, G., C. Jensen and D. Southgate (1997): Agricultural Economics and Agribusiness. Seventh Edition. John Wiley \& Sons, Inc.

CSAKI, C. and Z. LERMAN (2001): Farm Debt in the CIS: Multi-Country Study of Major Causes and Proposed Solutions. In: OECD (eds.): Agricultural Finance and Credit Infrastructure in Transition Economies: Focus on South Eastern Europe Region. Proceedings of OECD Expert Meeting, Portoroz, Slovenia, May 2001: 87-104.

DAWE, D. (1993): The Effects of Export Instability on Investment: The Information Content of Prices and Growth. Ph.D. Thesis, Harvard University.

DBR (2002): Data Base on the Emerging Markets. Deutsche Bank Research, www.dbresearch.com/servlet-free.

DE BeAufort Wijholds, O. and A. KAPTEYN (2001): Reserve Adequacy in Emerging Market Economies. IMF Working Paper No. 143.

DE Broeck, M. and T. SloK (2001): Interpreting Real Exchange Rate Movements in Transition Countries. IMF Working Paper No. 56.

DE Melo, M. and A. GelB (1996): A Comparative Analysis of Twenty-Eight Transition Economies in Europe and Asia. Post-Soviet Geography and Economics, Vol. 37, Issue 5: 265-285.

DekhtiarchuK, M. (1999): Exchange Rate Policy in Ukraine. Working Paper, HIIDCASE Project, www.harvard.kiev.ua.

Demyanchuk, V., V. Artiushyn, A. Vorobyov, I. Kobuta, M. Kobez, O. Protchenko, N. Pugachov, N. Seperovych, N. Stepanez, M. TEREshChenko, I. Chapko, O. Shevzov and O. YAroslavsky (2002): Agrarian Policy of Ukraine in 2002: Review and Perspectives. UNPD Agricultural Policy for Human Development Project, Kyiv, February.

DEmyanenKo, S. and S. ZoryA (2002): Taxation and Ukrainian Agriculture after 2004. Institute for Economic Research and Policy Consulting and German Advisory Group of Economic Reforms in Ukraine, Working Paper No. 18. 
DevereuX, J. and M. Connolly (1996): Commercial Policy, the Terms of Trade and Real Exchange Rate Revisited. Journal of Development Economics, Vol. 50: 8199.

Diaz-Alejandro, C. F. (1970): Essay of the Economic History of the Argentine Republic. Yale University Press.

Dicke, H., J. Donges, E. GERKEN and G. KIRKPATRCIK (1989): Effects of Agricultural Trade Liberalisation on West German's Economy. In: STOECKEL L., D. VINCENT and S. CUThBertson (eds.): Macroeconomic Consequences of Farm Support Policies. Center for International Economics Canberra. Duke University Press: 125-149.

DOMAC, I. and G. SHABSIGH (1999): Real Exchange Behaviour and Economic Growth: Evidence from Egypt, Jordan, Morocco, and Tunisia. IMF Working Paper No. 40.

Dornbusch, R. (1980): Open Economy Macroeconomics. Basis Book. Inc. Publishers.

DORNBUSCH, R. (1988a): Exchange Rates and Inflation. MIT Press.

DoRnBusch, R. (1988b): Overvaluation and Trade Balance. In: DoRNBUSCH R. and L. HELMERS (eds.): The Open Economy: Tools for Policy Makers in Developing Countries. Oxford University Press: 80-107.

DoRnBusch, R. (1996): Currency Crises in the Aftermath of Reform. www.mit.edu/ rudi.

DORnBUSCH, R. (2001): A Primer on Emerging Market Crisis. Massachusetts Institute of Technology.

Dornbusch, R., S. Fischer and R. StARTZ (1998): Macroeconomics. Seventh Edition. Irwin, McGraw-Hill.

Downey, M. (1999): Tax Breaks in Ukraine. The Case for and against their Withdrawal. UEPLAC-TASIC, December.

DrABEK, Z. and S. GRIFFITH-JONES (1998): Managing Capital Flows in Transition Economies with a Case-Study of Central and Eastern Europe. WTO Staff Working Paper ERAD-98-04.

EDWARDS, S. (1988): Exchange Rate Misalignment in Developing Countries. The Johns Hopkins University Press for the World Bank.

EDWARDS, S. (1989): Real Exchange Rates, Devaluation and Adjustment: Exchange Rate Policies in Developing Countries. MIT Press.

EDWARDS, S. (1994): Real and Monetary Determinants of Real Exchange Rate Behaviour: Theory and Evidence from Developing Countries. In: WILLIAMSON J. (eds.): Estimating Equilibrium Exchange Rates. Institute for International Economics, Washington, D.C: 20-61.

Edwards, S. (1997): Openness, Productivity, and Growth: What Do We Really Know? NBER Working Paper No. 5978.

Edwards, S. (2000): Exchange Rate Systems in Emerging Economies. NBER Working Paper No. 1345.

Edwards, S. and M. Savastano (1999): Exchange Rates in Emerging Economies: What Do We Know? What Do We Need to Know? NBER Working Paper No. 7228.

EGERT, B. (2002): Investigating the Balassa-Samuelson Hypothesis in the Transition. Economics of Transition, Vol. 10(2): 273-309. 
ElBADAWI, I. (1994): Estimating Long-Run Equilibrium Real Exchange Rates. In: WiLliamson J. (eds.): Estimating Equilibrium Exchange Rates. Institute for International Economics: 93-132.

Evenson, R. (1989): Open Discussion on LELE, U. and J. MelloR "Agricultural Growth, Its Determinants and Their Relationship to World Development: An Overview. In: MAUNDER A. and A. VALDES (eds.): Agriculture and Governments in an Interdependent World. Proceedings of Twentieth International Conference of Agricultural Economics Held at Buenos Aires, Argentina, August 24-31, 1998: 61-62.

FeltensteIn, A. (1989): Agricultural Policies and the US Federal Budget and US Trade Deficit. In: StOeckel A., D. Vincent and S. CUTHBertson (eds.): Macroeconomic Consequences of Farm Support Policies. Centre for International Economics Canberra. Duke University Press: 200-222.

Fischer, S., S. Sahay and C. Vegh (1998): From Transition to Market: Evidence and Growth Prospects. IMF Working Paper No. 52.

Frait, J. and L. KOMAREK (2001): Real Exchange Rate Trends in Transition Countries. Warwick Economic Research Paper No. 596, July.

FREEBAIRN, J. (1986): Implications of Wages and Industrial Policies on Competitiveness of Agricultural Export Industries. Paper presented at the Australian Agricultural Economic Society Policy Forum, Canberra.

Froot, K. and K. Rogoff (1995): Perspectives on PPP and the Long-Run Real Exchange Rate. In: Grossman G. and K. RogofF (eds.): Handbook of International Economics, Vol. 3. Amsterdam: North Holland Press.

FT (2001): United Kingdom's Farmer and Strong Pound. The Financial Times, November 15: 16.

FT (2002): Farmers in Compensation Push Due to the Strong Pound. The Financial Times, April 15: 15.

GERLOFF, A. (2001): Wechselkurspolitik in Mittel- und Osteuropa: Eine theoretische Analyse unter besonderer Berücksichtigung der Erfahrung der zehn Kandidaten für eine EU-Osterweiterung. Peter Lang Verlag.

Gertel, K. (1990): Farmland Prices and the Real Interest Rate on Farm Loans. The Journal of Agricultural Economics Research, Vol. 42, No. 1: 8-15.

GolOVEN, V. (2001): Notes on Trade Diversity in Ukraine. UEPLAC-TACIS. Ukrainian Economic Trends, December 2001: 82-88.

Grafe, C. and C. Wyplosz (1997): The Real Exchange Rate in Transition Economies. Center for Economic Policy Research.

GRANGER, C. (1986): Developments in the Study of Cointegrated Variables. Oxford Bulletin of Economics and Statistics, Vol. 48: 213-227.

Gylfason, T. (1995): The Macroeconomics of European Agriculture. Princeton Studies in International Finance No. 78: 15-27.

HALPERN, L. (1996): Real Exchange Rates and Exchange Rate Policy in Hungary. Center for Economic Policy Research.

HALPERN, L. and C. WyPlosz (1996): Equilibrium Exchange Rates in Transition Economies. IMF Working Paper No. 125. 
HALPERN, L. and C. WyPLOSZ (2001): Economic Transformation and Real Exchange Rates in the 2002s: The Balassa-Samuelson Connection. May, heiwww.unige.ch/ wyplosz.

HARTELl, J. and J. SwinnEN (2000): European Integration and the Political Economy of Central and Eastern European Agricultural Price and Trade Policy. In: TANGERMANN S. and M. BANSE (eds.): Central and Eastern European Agriculture in an Expanding European Union. CABI Publishing: 157-184.

HAVRYLYSHYN, O., I. IZVORSKY and R. VAN ROODEN (1999): Growth in Transition Economies 1990-97: An Econometric Analysis with Application to Ukraine. In: SiEDENBERG A. and L. HoffMANN (eds.): Ukraine at the Crossroads: Economic Reforms in International Perspective. Physika-Verlag, Heidelberg, New York: 2257.

HAYASHI, F. (2001): Results of the Second Expert Meeting on Agricultural Finance and Credit Infrastructure in Transition Economies. In: OECD (eds.): Agricultural Finance and Credit Infrastructure in Transition Economies: Focus on South Eastern Europe Region. Proceedings of OECD Expert Meeting, Portoroz, Slovenia, May 2001: 17-25.

Helmers, L. (1988): Real Exchange Rate. In: Dornbusch R. and L. Helmers (eds.): The Open Economy Tools for Policymakers in Developing Countries. Oxford University Press: 11-33.

HenRiChSMEYER, W. and H. WitZKe (1991): Agrarpolitik, Band 1: Agrarökonomische Grundlagen. Ulmer.

HeRtel, T., R. THOMPSON and M. TSigAs (1989): Economywide Effects of Unilateral Trade and Policy Liberalisation in US Agriculture. In: STOECKEL A., D. VINCENT and S. CuthBERTSON (eds.): Macroeconomic Consequences of Farm Support Policies. Center for International Economics Canberra. Duke University Press: 260-192.

HIID/CASE (1998): Fiscal Policy and New Instruments of Budget Deficit Financing in Ukraine. Harvard Institute for International Development, Center for Social and Economic Analysis, www.harvard.kiev.ua.

HinkLE, L. and P. MONTIEL (1999): Estimating Equilibrium Exchange Rates in Developing Countries. The World Bank.

HOFFMANN, L. and V. VINCENTZ (2002): Ukraine: Wachstum in einer virtuellen Wirtschaft. Osteuropa, $52 \mathrm{Jg}$., Sonderdruck.

HwA, E. (1988): The Contribution of Agriculture to Economic Growth: Some Empirical Evidence. World Development No. 16 (11): 1329-1339.

ICPS (2002): What Sources Form Commodity Structure of Ukraine's Foreign Trade? International Centre for Perspective Studies, Information Bulletin No. 159, www.icps.kiev.ua.

IER (2000-02): Monthly Economic Monitor Ukraine. Institute for Economic Research and Policy Consulting, Kyiv, Ukraine, www.ier.kiev.ua.

IER (2002): Ukraine and the World Economy: Risk Assessment and Policy Recommendations. Institute for Economic Research and Policy Consulting, Kyiv, Ukraine. 
IFS (2002): International Financial Statistics. International Monetary Fund, Washington, D.C., CD-Rom.

IMF (1997): Ukraine: Recent Economic Development. IMF Country Report, May.

IMF (1999): Ukraine: Recent Economic Developments. IMF Country Report, April.

IMF (2001): Ukraine: Statistical Appendix. IMF Country Report 28.

IN, F. and T. MounT (1994): Dynamic Macroeconomic Linkages to the Agricultural Sector: Application of Error Correction Models to Cointegrated Relationships. Avebury Press.

JOHANSEN, S. and K. JUSELIUS (1990): Maximum Likelyhood Estimation and Inference on Cointegration - with Applications to the Demand for Money. Oxford Bulletin of Economics and Statistics Vol. 52, No. 2: 169-210.

Johnson, G. D. (1993a): Historical Experience of Eastern and Central European and Soviet Agriculture. In: Braverman A., K. BroOKS and C. CsAKI (eds.): The Agricultural Transition in Central and Eastern Europe and the Former USSR. The World Bank, Washington, D.C.: 11-26.

Johnson, G. D. (1993b): Role of Agriculture in Economic Development Revisited. Agricultural Economics, Vol. 8: 421-434.

Johnson, S., D. KaUfmanN and A. ShleIfER (1997): The Unofficial Economy in Transition. Brooking Papers on Economic Activity.

Johnston, B. and J. Mellor (1961): The Role of Agriculture in Economic Development. American Economic Review No. 51: 566-593.

KAABIA, M. and J. GIL (2000): Short- and Long-Run Effects of Macroeconomic Variables on the Spanish Agricultural Sector. European Review of Agricultural Economics, Vol. 27 (4): 449-471.

KENEN, P. (eds.) (1995): Understanding Interdependence: The Macroeconomics of the Open Economy. Princeton, N.J.: Princeton University Press.

KIREEV, O. (2002): High Interest Rates: Internal Problems of Banking Sector. Analytical Center of the NBU Council on Money and Credit Policy, Notatky No. 4, March 21-27.

Knutson, R., J. Penn and W. Boehm (1995): Agricultural and Food Policy. Third Edition. Prentice-Hall, Inc.

KobutA, I. and O. SHEvzov (2002): Domestic Support of Agriculture in the Context of Ukraine's Accession to the World Trade Organisation. Agricultural Policy for Human Development Project, Ukraine, August 2002 (No. 14).

Koester, U. (1991): Economy-Wide Costs of Farm Support Policies in the Major Industrial Countries. In: Burger K., M. DE Groot, J. POST and V. ZACHARIASSE (eds.): Agricultural Economics and Policy: International Challenges for the Nineties. Developments in Agricultural Economics, 7. Elsevier: 5-17.

KoEster, U. (1998): Introduction to the Special Issue: Transforming Socialist Agriculture: From Plan to Market. European Review of Agricultural Economics No. 25: 281-288.

Koester, U. (1999): Die Bedeutung der Organisationsstruktur landwirtschaftlicher Unternehmen für die Entwicklung des ukrainischen Agrarsektors. In: VON CRAMON-TAubadel S. and L. STRIEWE (eds.): Die Transformation der 
ukrainischen Landwirtschaft: Ein Weites Feld. Wissenschaftsverlag Vauk Kiel KG: $189-211$.

KoESTER, U. (2001): Agricultural Finance and Institutional Reforms in Transition Economies: The 1990s and Challenges Ahead. Quarterly Journal of International Agriculture Vol. 40, No. 4: 301-323.

Koester, U. and S. VON CRAMON-TAUBADEL (2002): Intertemporale Preiszusammenhang. Skriptum.

KrajNyAK, K. and J. ZeTTELMEYER (1997): Competitiveness in Transition Economies: What Scope for Real Appreciation? IMF Working Paper No.149.

KROT, Y. (2002): Natural Restrictions of Export. www.AgriUkraine.com, January 18, 2002.

Krueger, A., M. Schiff and A. VAldes (1988): Agricultural Incentives in Developing Countries: Measuring the Effects of Sectoral and Economic Wide Policies. World Bank Economic Review, Volume No. 2, Issue 3: 255-271.

KSTUA (2001): Technological Maps of Crop Production. Joint Study of Kharkiv State Technical University of Agriculture, Ministry of Agricultural Policy of Ukraine and Main Department for Agriculture and Food at Kharkiv State Oblast Administration.

KUHL, M. (1998): Landwirtschaft und Makroökonomie: Abbildung ausgewälter Zussamenhänge mit Vektor-Autoregressive Modellen. Inaugural-Dissertation zur Erlangung des Doktorgrades des Fachbereichs Wirtschaftswissenschaften der Johann Wolfgang Goethe-Universität, Frankfurt am Main.

Kuralbaeva, K., A. KutAn and M. WyzAn (2001): Is Kazakhstan Vulnerable to the Dutch Disease? ZEI Working Paper No. B29.

Kurkalova, L. and H. Jensen (1996): Production Efficiency in Ukrainian Agriculture and the Process of Economic Reforms. Centre for Agricultural and Rural Development. Iowa State University, September.

Kwiecinski, A. and N. Pescatore (2000): Sectoral Agricultural Policies and Estimates of PSEs for Russia in the Transition Period. In: WeHrheim P., E. SEROVA, K. FROHBERG and J. VON BRAUN (eds.): Russia's Agro-Food Sector: Towards Truly Functioning Markets. Kluwer Academic Publishers: 111-127.

LADYGINA, E. (1998): Tariff and Non-Tariff Regulation of Foreign Trade for Agricultural Products in Ukraine During 1993-1998. Centre for Privatisation and Economic Reform in Agriculture, Kyiv, Ukraine.

LAKEMEYER, E. (2002): Die Bildung von Agrarholdings im Agrar- und Ernдhrungssektor in der Russischen Föderation. Masterarbeit im wissenschaftlichen Studiengang Agrarwissenschaften an der Georg-August-Universitдt Göttingen, Fakultät für Agrarwissenschaft.

LEGEIDA, N. (2001): Implicit Subsidies in Ukraine: Estimation, Developments and Policy Implications. Institute for Economic Research and Policy Consulting, Working Paper No. 10, Kyiv.

LERMAN, Z. and C. CSAKI (1999): Ukraine: Review of Farm Restructuring Experiences. The World Bank.

LEVINE, H. and J. SzYRMER (2000): Institutional Development and Fiscal Policy in Countries in Transition. In: SZYRMER J. and K. SULTAN (eds.): Ukraine through 
Transition: Challenges and Strategies. Harvard/CASE Ukraine Project, Kyiv: Alterpress: 10-15.

LeVINE, R. (1997): Financial Development and Economic Growth: Views and Agenda. Journal of Economic Literature: 688-726.

LEWIS, A. (1954): Economic Development with Unlimited Supplies of Labor. The Manchester School No. 22: 3-42.

LIEFERT, W. (2000): Crisis Cuts Russia's Food Consumptions and Imports. In: ERS (eds.): International Financial Crises and Agriculture: Situation and Outlook Series. Economic Research Service, USDA. International Agriculture and Trade Reports: 54-57.

LIEFERT, W. and J. SwINNEN (2002): Changes in Agricultural Markets in Transition Economies. Economic Research Service, USDA, Agricultural Economic Report No. 806.

LINNE, T. (1998): Requirements for the Future Exchange Rate Policies of the Central and East European Transformation Economies. Presentation at the Seminar of Scientific Collegium of IHW on July 3, 1998 in Halle (Saale).

LIPSCHITZ, L. and D. MACDONALD (1992): Real Exchange Rate and Competitiveness: A Clarification of Concepts and Some Measurement for Europe. Empirica: 37-69.

LIPTON, K. (1991): Farming Illustrates Linkages in US and World Economies. Food Review, ERS/USDA, January-March, Washington, D.C.: 3.

LissitsA, A. (2002): Der Transformationsprozesse in der Landwirtschaft der Ukraine Eine Analyse der Effizienz und Produktivität von Großbetrieben. Shaker Verlag, Aachen.

LissitsA, A. and M. ODENING (2001): Effizienz und Totale Faktorproduktivität in der ukrainischen Landwirtschaft im Transformationsprozess. Humbolt-Universität zu Berlin, Working Paper No. 58.

LiTTLE, I., T. SCiTOvSKY and M. ScotT (1970): Industry and Trade in Some Developing Countries. Oxford University Press and OECD.

LUNINA, I. and F. VINCENTZ (1998): Subsidization of Enterprises in Ukraine. In: SiEDENBERG A. and L. HofFMAN (eds.): Ukraine at the Crossroads: Economic Reforms in International Perspective. Feniks: 118-130.

MACOURS, K. and J. SwINNEN (2000): Causes of Output Decline in Economic Transition: The Case of Central and Eastern European Agriculture. Journal of Comparative Economics, Vol. 28, Issue 1: 172-206.

MAmingi, N. (1997): The Impact of Prices and Macroeconomic Policies on Agricultural Supply: A Synthethis of Available Results. Agricultural Economics, Vol. 16: 1734.

Mankovska, N., R. GiUCCI and O. BetLiY (2002): The Influence of the Real Effective Exchange Rate on the Trade Balance in Ukraine. UEPLAC, Ukrainian Economic Trends, Quarterly Issue, March.

Meade, J. E. (1951): The Balance of Payments. Oxford University Press.

Melota, I. and P. Gregory (2001): The Shadow Economy in Ukraine: Measurement Problems. Institute for Economic Research and Policy Consulting, Kyiv. Working Paper No. 11. 
Michaely, M. (1999): Ukraine: Foreign Trade and Commercial Policies. World Bank, August 12.

MinAgro (2002): Proposals to Make Changes to the Law of Ukraine "On Fixed Agricultural Tax" and "Value-Added Tax". Ministry of Agricultural Policy of Ukraine.

MinAgro (1992-2000): Annual Consolidated Collective Farm Accounting Reports. Ministry of Agricultural Policy of Ukraine, Kyiv.

MinECON (2001): Monitoring of Macroeconomic and Branch Indicators. Ministry of Economy of Ukraine. Issue No. 12, December.

MinFIN (2002): Report on State Debts in Ukraine. Ministry of Finance of Ukraine, Kyiv.

Moellers, F. and A. Siedenberg (1999): The Interplay between Monetary Policy and Reform Policy in Ukraine - an Overview. In: SiEDENBERG A. and L. HofFMANN (eds.): Ukraine at the Crossroads: Economic Reforms in International Perspective. Physica-Verlag, Heidelberg: 58-79.

Mongardini, J. (1998): Estimating Egypt's Equilibrium Real Exchange Rate. IMF Working Paper 5.

Monke, E. and S. PERSON (1989): The Policy Analysis Matrix for Agricultural Development. Ithaca and London. Cornell University Press.

MontiEL, P. (1999): Determinants of the Long Run Equilibrium Real Exchange Rate: An Analytical Model. In: HinkLE L. and P. MONTIEL (eds.): Exchange Rate Misalignment: Concepts and Measurement for Developing Countries. Oxford University Press, The World Bank Study: 264-289.

Mosher, A. (1966): Getting Agriculture Moving: Essentials for Development and Modernization. New York: Praeger.

Movchan, V. (2002): Non-Tariff Barriers in Ukraine's Foreign Trade: Did Liberalisation Occur? Paper presented at Sixth Annual EERC International Academic Conference "The Economic Transition of Ukraine" on May 15-16, 2002 at National University "Kyiv-Mohyla Academy", Ukraine.

MundlaK, Y. (1989): Agricultural Growth and World Developments. In: MAUNDER, A. and A. VALDES (eds.): Agriculture and Governments in an Interdependent World. Proceedings of the Twentieth International Conference of Agricultural Economists of 1988.

MundlaK, Y. (2000): Agriculture and Economic Growth: Theory and Measurement. Harvard University Press.

Murova, O. (2000): Farm Efficiency in Ukraine and Russia: Comparable Analysis. Ph.D. Thesis. Mississippi State University.

NBU (2001): Statistical Data. The National Bank of Ukraine, www.bank.gov.ua.

NBU (2002a): Balance of Payments of Ukraine, Different Years. The National Bank of Ukraine. www.bank.gov.ua.

NBU (2002b): Statistical Data. The National Bank of Ukraine, www.bank.gov.ua.

NeDOBOROVSKY, A. (2001): Field Study of Farms in Zhytomyr Oblast. Unpublished Report. Institute for Agricultural Development of the Central and Eastern Europe, Halle/Saale.

NiLES, K. and D. ORden (1998): Macroeconomic Policies and US Agriculture. Virginia Polytechnic Institute and State University. 
NuTI, D. M. (1996): Inflation, Interest and Exchange Rates in the Transition. Economics in Transition: $137-158$.

ODLING-SMEE, J. (2001): Ukraine after 10 Years of Transition Experience. Lecture at the National University "Kyiv-Mohyla Academy", Kyiv, February 5, 2001.

OdLing-SmeE, J. (2003): Recent Economic Developments and Prospects: Ukraine in the Regional and World Context. Lecture of Director of the European II Department of the International Monetary Fund (IMF), Washington, D.C. presented at National University "Kyiv-Mohyla Academy" Kyiv, Ukraine, February 17, 2003.

ODLING-SMEE, J. and R. VAN ROODEN (1999): Growth in Ukraine - Lessons from Other Transition Countries. In: SiEDENBERG A. and L. HofFMANN (eds.): Ukraine at the Crossroads: Economic Reforms in International Perspective. Physica-Verlag, Heidelberg: 9-21.

OECD (2000): Agricultural Policies in OECD Countries. Organisation for Economic Cooperation and Development, Paris.

OECD (2001a): Main Economic Indicators. Organisation for Economic Co-Operation and Development, Paris.

OECD (2001b): The Uruguay Round Agreement on Agriculture: An Evaluation of Its Implementation in OECD Countries. Organisation for Economic Co-Operation and Development, Agriculture and Food, Paris.

OECD (2002): Agricultural Policies in OECD Countries: Monitoring and Evaluation 2002. Organisation for Economic Co-Operation and Development, Paris, www.oecd.org.

O'MARA, P., B. Crofts and R. COOTE (1987): Prospects for Exchange Rates and Interest Rates: Implications for Farmers. Quarterly Review of the Rural Economy No. 9(4), December: 440-448.

Osborne, S. and M. Trueblood (2002): Agricultural Productivity and Efficiency in Russia and Ukraine: Building on a Decade of Reform. Economic Research Service, USDA, Agricultural Economic Report No. 813.

PaAlberg, P. L. and R. Chambers (eds.) (1988): Macroeconomics, Agriculture, and Exchange Rates. Westview Press Inc., Boulder \&v.

Pankiv, I., V. Petruniv, U. Momont and T. Die (2000): Handbook on Agribusiness and Management. Lviv Agrarian Extension Service (LADS).

Penson, J., R. POPE and M. COOK (1986): Introduction to Agricultural Economics. Prentice-Hall, Inc.

Petrick, M. (2002): Credit Rationing in the Polish Farm Sector: A Microeconometric Analysis Based on Survey Data. Paper presented at X EAAE Congress "Exploring Diversity in the European Agri-Food System", Zaragoza (Spain), August 28-31, 2002.

PRIKHODKO, D. (2002): Ukraine: Grain and Feed: How Is Ukrainian Grain Competitive? FAS/USDA, U.S. Embassy to Ukraine, Gain Report UP 2006 from August 2.

Prosorov, Y. (2002): Reason of Weak Influence of Changes of NBU Refinancing Rate on Commercial Lending Rates - Existence of Deep "Institutional" Trap. Analytical Center of the NBU Council on Money and Credit Policy, Notatky No. 1, March 713. 
PuHACHOV, M. and K. PuHACHOVA (2001): Evolution of Farm Structures in Ukraine. In: von Cramon-Taubadel S., S. Zorya and L. Striewe (eds.): Policies and Agricultural Development in Ukraine. Shaker Verlag: 190-200.

PyNZENYK, V. (2000): Fiscal Reform in Ukraine: The Problems to Be Solved. In: SZYRMER J. and K. SULTAN (eds.): Ukraine through Transition: Challenges and Strategies. HIID/CASE Project, Kyiv: Alterpress.

QUAISSER, W. (1999): Aussenhandelsentwicklung und Wettbewerbsposition der Ukraine im Handel mit der Europäischen Union. Deutsche Beratung Gruppe in Wirtschaft in der Ukraine, Papier No. 13.

QueReshi, S., I. NABI and R. FARUQEe (1996): Rural Finance for Growth and Poverty Alleviation in Pakistan. The World Bank, Policy Research Working Paper No. 1593.

RAZIN, O. and S. Collins (1997): Real Exchange Rate Misalignment and Growth. NBER Working Paper 6174.

Robinson, S., M. KiLKenNy and I. Adelman (1989): The Effects of Agricultural Trade Liberalisation on the US Economy: Projections to 1991. In: STOECKEL A., D. VINCENT and S. CUTHBERTSON (eds.): Macroeconomic Consequences of Farm Support Policies. Center for International Economics Canberra. Duke University Press: 222-259.

Rogoff, K. (1996): The Purchasing Power Parity Puzzle. Journal of Economic Literature, Vol. 134, No. 2: 647-668.

Roubini, N. and P. WAChTEl (1998): Current Account Sustainability in Transition Economies. NBER Working Paper No. 6468.

SACHS, J. (1996): The Transition at Mid Decade. Economic Transition in Central and Eastern Europe, Vol. 86, No. 2: 128-133.

SAlter, W. (1959): Internal and External Balance: The Role of Price and Expenditure Effects. Economic Record, Vol. 35: 226-238.

SAUER, H. (2002): Die Struktur und die Wettbewerbsfähigkeit der ukrainischen Milchwirtschaft: Teil 2: Milchverarbeitung. Masterarbeit im wissenschaftlichen Studiengang Agrarwissenschaften an der Georg-August-Universität Göttingen, Fakultät für Agrarwissenschaft.

SCHEUERLEIN, A. (1997): Finanzmanagement für Landwirte: Beispiele, Anwendungen Beurteilungen. BLV Verlagsgesselschaft $\mathrm{mbH}$, München.

SCHIFF, M. and A. VAldes (1992): The Political Economy of Agricultural Pricing Policy. Vol. 4. A Synthesis of the Economics in Developing Countries. Baltimore, Johns Hopkins University Press.

SCHIFF, M. and A. VALDES (1999): Agriculture and the Macroeconomy. The World Bank.

SCHMITZ, P. and M. HofFMANN (1996): Landwirtschaft und Makroökonomie Abbildung ausgewählter Zusammenhänge mit einem VAR-Modell. Institute for Agricultural Policy, University of Giessen, Working Paper No. 39.

SchuH, G. (1974): The Exchange Rate and U.S. Agriculture. American Journal of Agricultural Economics, Vol. 56: 1-13.

SchuH, G. (1989): Macro Linkages and Agriculture: The United States Experience. In: MAUNDER A. and A. VALDES (eds.): Agriculture and Governments in an 
Interdependent World. Proceedings of the Twentieth International Conference of Agricultural Economists, Dartmouth: 533-541.

SEDIK, D. (2000): Farm Profits and Agricultural Policies in Ukraine. Iowa State University Ukrainian Agricultural Policy Project. Working Paper No. 8.

SEDIK, D. (2001): Large Farm Debt in Ukraine. In: OECD (eds.): Agricultural Finance and Credit Infrastructure in Transition Economies: Focus on South Eastern Europe Region. Proceedings of OECD Expert Meeting, Portoroz, Slovenia, May 2001: 105-121.

Sedik, D., N. Seperovych, M. Puhachov, I. Chapko, I. Kobuta, V. Noga and V. Zhugadlo (2000): The Farm Debt Problem in Ukraine. Iowa State University Ukraine Agricultural Policy Project.

ShANE, M. (2001): Exchange Rate Indexes and US Agricultural Trade. Economic Research Service, USDA. Agricultural Outlook/January-February 2001.

SIRIN, K. and S. ZORYA (2001): Can the Crisis in Ukrainian Agriculture Be Attributed to Price Disparity? In: vON CRAMON-TAubadel S., S. ZORYA and L. STRIEWE (eds.): Policies and Agricultural Development in Ukraine. Shaker Verlag: 87-101.

SJAASTAD, L. (1980): Commercial Policy, "True Tariffs", and Relative Prices. In: BLACK J. and B. Hindley (eds.): Current Issues in Commercial Policy and Diplomacy. St. Martins Press: 15-35.

SNAPE, R. (1989): Real Exchange Rates, Real Interest Rates and Agriculture. MAUNDER A. and A. VALDES. Agriculture and Governments in an Interdependent World, Proceedings of Twentieth International Conference of Agricultural Economics. Buenos Aires.

SpychaK, O. (2000): Prices, Costs and Profits of Agricultural Production and Infrastructure of Food Market in Ukraine. Institute for Agricultural Economics, UAAS, Kyiv, Ukraine.

SSCU (2001a): Expected Results of Farm Activity in Ukraine in 2001. State Statistics Committee of Ukraine, Express Report No. 349 from December 5, 2001.

SSCU (2001b): Macroeconomic Indicators in Ukraine: Methodological Aspect. State Statistics Committee of Ukraine, round table held on December 8, 2001.

SSCU (2001c): Reports on Sales of the Agricultural Commodities through Different Marketing Channels. State Statistics Committee of Ukraine, Kyiv.

SSCU (2001d): Reports on Sales of the Agricultural Commodities through Different Marketing Channels. State Statistics Committee of Ukraine, Kyiv.

SSCU (2001e): Statistical Yearbook of Agriculture in 2000. State Statistics Committee of Ukraine, Kyiv.

SSCU (2001f): Statistical Yearbook of Ukraine. State Statistics Committee of Ukraine, Kyiv.

SSCU (2002): Statistical Yearbook of Agriculture in 2001. State Statistics Committee of Ukraine, Kyiv.

SSCU (different years): Foreign Agricultural Trade Statistics. State Statistics Committee of Ukraine, Kyiv.

StOeCKEL, L. and J. BRECKLING (1989): Some Economywide Effects of Agricultural Policies in the European Community: A General Equilibrium Study. In: STOECKEL

L., D. VinCENT and S. CUTHBERTSON (eds.): Macroeconomic Consequences of 
Farm Support Policies. Center for International Economics Canberra. Duke University Press: 94-124.

STRIEWE, L. (2001): Who Gains and Loses - Import Tariffs and Tariff Rate Quotas for Sugar and Grain in Ukraine. In: VON CRAMON-TAUBADEL S., S. ZORYA and L. STRIEWE (eds.): Policies and Agricultural Development in Ukraine. Shaker Verlag: 134-143.

StRIEWE, L., I. CHAPKO and A. STARIKOV (2001a): Rural Finance in Ukraine - Extending the Frontier. In: VON CRAMON-TAUBADEL, S., S. ZORYA and L. STRIEWE (eds.): Policies and Agricultural Development in Ukraine. Shaker Verlag: 53-69.

Striewe, L., V. Galushko and S. von Cramon-TAubadel (2001b): Promoting Food Security in Ukraine. In: VON CRAMON-TAUBADEL S., S. ZORYA and L. STRIEWE (eds.): Policies and Agricultural Development in Ukraine. Shaker Verlag: 114133.

STRIEWE, L. and S. VON CRAMON-TAUBADEL (1999): Die Getreideproduktion der Ukraine: Verpasste Chancen und Dringender Handlungsbedarf. In: VON CRAMONTAUBADEL S. and L. STRIEWE (eds.): Die Transformation der Landwirtschaft in der Ukraine: Ein Weites Feld. Wissenschaftsverlag Vauk Kiel KG: 74-87.

Striewe, L., S. von Cramon-TAubadel and K. Sirin (2001c): Financial Problems in Ukrainian Agriculture: Diagnosis and Possible Solutions. In: BOSTYN F. and A. BOYTSUN (eds.): Agricultural Reforms in Ukraine: 25-39.

Sultan, K. (2000): Tax Reforms in Ukraine - Gaps and Lessons. In: SzYRMER J. and K. SUlTAN (eds.): Ukraine through Transition: Challenges and Strategies. Harvard/CASE Ukraine Project, Kyiv: Alterpress: 25-32.

Sultan, K. and L. PASIKA (2000): Budget Performance and Fiscal Discipline in Ukraine. In: SzYRMER J. (eds.): The Barter Economy: Non-Monetary Transactions in Ukraine's Budget Sector. Harvard/CASE Ukraine Project: 44-51.

SwAN, T. W. (1960): Economic Control in a Dependent Economy. Economic Record, Vol. 36.

SwAN, T. W. (1963): Longer-Run Problems of the Balance of Payment. In: ARNDT H. W. and M. W. CORDEN (eds.): The Australian Economy. A Volume of Readings. F.W. Cheshire Publishers.

SwINNEN, J. (2001): Ten Years of Agricultural Transition in Central and Eastern Europe: Some Lessons for Ukraine. In: VON CRAMON-TAUBADEL S., S. ZORYA and L. STRIEWE (eds.): Policies and Agricultural Development in Ukraine. Shaker Verlag: 6-17.

SwINNEN, J. (2002): Major Trends and Developments in the Agribusiness and Agricultural Sectors in CEE and NIS. Paper presented at the EBRD/FAO Conference on "Investments in Agribusiness and Agriculture in CEE and the CIS", Budapest 20/21, March 2002.

Swinnen, J. and H. Gow (1999): Agricultural Credit Problems and Policies During the Transition to a Market Economy in Central and Eastern Europe. Food Policy, Vol. 21, Issue 1: 21-47.

SzYrMER, J. (2000): Monetizing a Barterized Economy: Withering Away of NonMonetary Transactions with the Budget in Ukraine. In: SZYRMER J. (eds.): The 
Barter Economy: Non-Monetary Transactions in Ukraine Budget Sector. Harvard/CASE Ukraine Project: 15-21.

TARASEVYCH, A. (1999): Farming Practise in Ukraine. Short Analysis of Incomes and Costs. USAID Agricultural Project "Center for Privatisation and Economic Reform in Agriculture", Working Paper No. 18.

Thiessen, U. and L. Hoffmann (1999): Principles for a Public Debt Strategy in Ukraine. In: SiEDENBERG A. and L. HOFFMANN (eds.): Ukraine at the Crossroads: Economic Reforms in International Perspectives. Physica-Verlag, Heidelberg: 81105.

ThOMPSON, R. (1988): US Macroeconomic Policy and Agriculture. In: PAALBERG P. and R. CHAMBers (eds.): Macroeconomics, Agriculture, and Exchange Rates. Westview Press: 219-226.

TIMMER, P. (1998a): The Agricultural Transformation. In: EICHER C. and J. STAATZ (eds.): International Agricultural Development. Third Edition. The John Hopkins University Press: 113-136.

TIMMER, P. (1998b): The Macroeconomics of Food and Agriculture. In: EICHER C. and J. StAATZ (eds.): International Agricultural Development. Third Edition. The John Hopkins University Press: 187-211.

Timmer, P., W. FAlCON and S. PEARSON (1983): Food Policy Analysis. Baltimore: The Johns Hopkin University Press for the World Bank.

Torgenson, P. and K. HAmREK (2000): The 1980's Debt Crisis Hurt US Rural Economy Far More Than the 1990's Financial Crises. In: ERS (eds.): International Financial Crises and Agriculture: Situation and Outlook Series. Economic Research Service, USDA. International Financial Crises and Agriculture.: 15-19.

TRuss, W. (2001): Interest Rate Cut Will Save Australian Farmers Hundreds of Dollars. Ministry for Agriculture, Fisheries and Forestry, April 6.

TSAKOK, I. (1990): Agricultural Price Policy: A Practitioner's Guide to Partial Equilibrium Analysis. Ithaca-Cornell University Press.

UEPLAC (2002): Ukrainian Economic Trends. TACIS-UEPLAC, Kyiv, Ukraine.

UKRAGROCONSULT (2001-2002): Agrinews. Weekly Issues.

UKRRADA (2001): Unified Customs Tariff Code. www.rada.kiev.ua.

UKRRADA (diff. years): Laws on State Budget of Ukraine. The Parliment of Ukraine, www.rada.kiev.ua.

VAKHNENKO, T. (2001): Ukraine's Economy in 2001: Major Trends and Development Factors. UEPLAC, Ukrainian Economic Trends, September-November.

VAlDES, A. (1989): Impact of Trade and Macroeconomic Policies on Agricultural Growth. In: LONGWORTH J. W. (eds.): China's Rural Development Miracle with International Comparisons: 136-155.

VAn AtTA, D., S. Zorya, M. Betliy and O. Shanin (1998): The Ukrainian State Grain Order. Center for Privatisation and Economic Reform in Agriculture.

VENEMA, J. (2002): Die Struktur und Die Wettbewerbsfähigkeit der ukrainischen Milchwirtschaft: Teil 1: Milchproduktion. Masterarbeit im wissenschaftlichen Studiengang Agrarwissenschaften an der Georg-August-Universität Göttingen, Fakultät für Agrarwissenschaft.

VERNITSKY, M. (2001): Grain Report. Olimpex Ltd., December 20. 
VINCENT, D. (1989a): Domestic Effects of Agricultural Protection in Asia Countries with Special Reference to Korea. In: Stoeckel A., D. Vincent and S. CuthBertson (eds.): Macroeconomic Consequences of Farm Support Policies. Center for International Economics Canberra. Duke University Press: 125-149.

Vincent, D. (1989b): Effects of Agricultural Protection in Japan: An Economywide Analysis. In: StOeCKel A., D. Vincent and S. CuthBertson (eds.): Macroeconomic Consequences of Farm Support Policies. Center for International Economics Canberra. Duke University Press: 173-199.

Volosovych, V. (2002): The Feasibility of Monetary Targeting in Ukraine. In: VON Cramon-Taubadel S. and I. AKIMOVA (eds.): Fostering Sustainable Growth in Ukraine. Physica-Verlag, Heidelberg, New York: 289-301.

von CRAmon-TAUBADEL, S. (1994): The European Community Common Agricultural Policy and the Search for a Unit of Account. Oxford Agrarian Studies, Vol. 22, No. 2: 107-122.

von Cramon-Taubadel, S. (2002): Ukrainian Trade Policy: A Turn for the Worse? German Advisory Group on Economic Reform in Ukraine.

von Cramon-Taubadel, S. and C. Benecke (2001): The Present and Future Profitability of Sugar Production in Ukraine. In: VON CRAMON-TAUBADEL S., S. ZORYA and L. STRIEWE (eds.): Policies and Agricultural Development in Ukraine. Shaker Verlag, Aachen: 214-232.

von Cramon-Taubadel, S. and L. StRiewe (1999): Der Markt für Ölsaaten in der Ukraine: Erfolgsgeschichte oder Geschichte? In: VON CRAMON-TAUBADEL S. and L. STRIEWE (eds.): Die Transformation der Landwirtschaft in der Ukraine: Ein Weites Feld. Wissenschaftsverlag Vauk Kiel KG.

VON CRAMON-TAUbadel, S. and L. STRIEWE (2001): A Market for Agricultural Land in Ukraine. In: vON CRAMON-TAUBADEL S., S. ZORYA and L. STRIEWE (eds.): Policies and Agricultural Development in Ukraine. Shaker Verlag: 201-212.

VON CRAMON-TAUBADEL, S. and S. ZORYA (2000): Agricultural Aspects of the Ukrainian Membership of the WTO. Institute for Economic Research and Policy Consulting.

VON CRAmon-TAubadel, S. and S. Zorya (2001): Agricultural Policy Reform in Ukraine: Sequencing and Results. In: VON CRAMON-TAUBADEL S., S. ZORYA and L. STRIEWE (eds.): Policies and Agricultural Development in Ukraine. Shaker Verlag: 20-31.

von Cramon-Taubadel, S., S. Zorya and L. Striewe (eds.) (2001): Policies and Agricultural Development in Ukraine. Aachen, Shaker Verlag.

VON PISCHKE, J. D. (1999): Preconditions for Sustainable Agricultural Finance and Credit Systems. In: OECD (eds.): Agricultural Finance and Credit Infrastructure in Transition Economies, Proceedings of OECD Expert Meeting: 38-54.

VON PISChKe, J. D. (2001): Public Policy and Preconditions for Sustainable Rural Finance Systems. In: OECD (eds.): Agricultural Finance and Credit Infrastructure in Transition Economies: Focus on South Eastern Europe Region. Proceedings of OECD Expert Meeting, Portoroz, Slovenia, May 2001: 35-52.

WeHRHEIM, P. and M. WIEBELT (1997): Zur Konsolidierung des russischen Staatshaushalts: Eine allgemeine Gleichgewichtsanalyse finanzpolitischer 
Alternativen und deren Auswirkungen auf die Ernährungswirtschaft. Institut für Ernährungswirtschaft und Verbrauchslehre, Universitzt Kiel, Disskussionsbeitrag Nr. 7, April.

Williams, J. and B. Wright (1991): Storage and Commodity Markets. Cambridge University Press.

Williamson, J. (eds.) (1994): Estimating Equilibrium Exchange Rates. Institute for International Economics.

Wong, L. and V. RutTAn (1990): A Comparative Analysis of Agricultural Productivity Trends in Centrally Planned Economies. In: GRAY K. (eds.): Soviet Agriculture: Comparative Perspectives. Iowa State University Press / Ames: 23-48.

WORLD BANK (1994): Ukraine: The Agriculture Sector in Transition. The World Bank, Washington, D.C.

Zeller, M., A. Ahmed, C. Babu, A. Diagu and M. Sharma (1996): Rural Financial Policies for Food Security of the Poor: Methodologies for a Multicountry Research Project. International Food Policy Research Institute, Food Consumption and Nutrition Division Disscusion Paper No. 11.

Zeller, M. and M. ShARMA (1998): Rural Finance and Poverty Alleviation. International Food Policy Research Institute, Food Policy Report, June.

ZhYLYAEV, I. and V. ORLOVA (2000): Non-Monetary Transactions of the Budget. In: SZYRMER J. (eds.): The Barter Economy: Non-Monetary Transactions in Ukraine's Budget Sector. Harvard/CASE Ukraine Project, Kyiv: 53-121.

ZORYA, S. (2001a): Agriculture and Current Account Sustainability in Ukraine. In: VON Cramon-Taubadel S., S. Zorya and L. Striewe (eds.): Policies and Agricultural Development in Ukraine. Shaker Verlag: 32-49.

ZORYA, S. (2001b): Regional Agricultural Trade Model in Ukraine. In: VON CRAMONTAubadel S., S. Zorya and L. STRIEWE (eds.): Policies and Agricultural Development in Ukraine. Shaker Verlag: 144-153.

Zorya, S., H. Sauer, L. Striewe, J. Venema and T. Hemme (2002): Das Potential der Milcherzeugung und Milchverarbeitung in der Ukraine. Paper presented at 42 Meeting of GEWISOLA in Halle/Saale, September 30-October 02, 2002.

ZORYA, S. and S. VON CRAMON-TAUBADEL (2002): (When) Will Ukraine Be a Global Player on World Agricultural Markets? Paper is presented at X European Congress of Agricultural Economists on August 28-31, 2002 in Zaragoza, Spain. 


\section{Curriculum Vitae}

Name: Sergiy Zorya

married, two children (born in 1995 and 1998).

Aug. 24, 1974 born in Zhytomyr, Ukraine

Parents: Ivan and Valentina Zorya

1991 Graduated from the secondary school No. 4 with physical and mathematical specialisation, Zhytomyr, Ukraine

1991-96 Studies in agricultural science, specialisation in Agricultural Economics, Diploma with distinction, State Academy of Agriculture and Ecology of Ukraine, Zhytomyr

1996-97 Deputy Chief Accountant of JSC “Zhytomyragrokhim"

1997-98 Economic Analyst of Centre for Privatisation and Economic Reform in Agriculture, Kyiv, Ukraine (CARD Iowa State University and USAIDfunded project)

1998-99 Commercial Specialist in agribusiness of the U.S. \& Foreign Commercial Service, U.S. Embassy to Ukraine, Kyiv

Since 1999 Research Assistant and Ph.D. student of the Department of Agricultural Policy, Institute of Agricultural Economics, Georg-August University of Göttingen, Germany 